
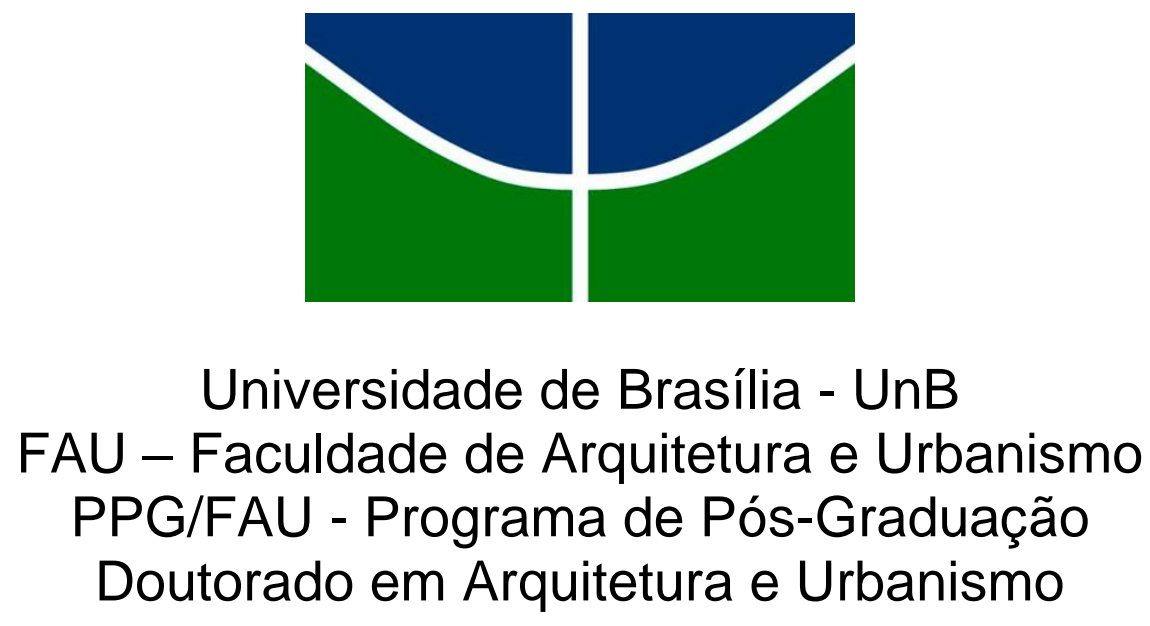

TESE DE DOUTORADO

EU VOU, EU VOU, PARA ESCOLA A PÉ EU VOU... FORMA URBANA E DESLOCAMENTO DAS CRIANÇAS ATÉ A ESCOLA NA CIDADE DE GOIÂNIA

\author{
LUCIANA ARAUJO AZEVÊDO
}

ORIENTADOR: PROF. DR. MÁRCIO AUGUSTO ROMA BUZAR

Brasília, Dezembro 2016 


\title{
EU VOU, EU VOU, PARA ESCOLA A PÉ EU VOU... FORMA URBANA E DESLOCAMENTO DAS CRIANÇAS ATÉ A ESCOLA NA CIDADE DE GOIÂNIA
}

\author{
Tese de Doutorado apresentada como \\ requisito obrigatório para obtenção do \\ grau de Doutor pelo Programa de \\ Pesquisa e Pós-Graduação em \\ Arquitetura e Urbanismo da Faculdade \\ de Arquitetura e Urbanismo da \\ Universidade de Brasília.
}

Área de Concentração: Tecnologia, Ambiente e Sustentabilidade. Orientador: Prof. Dr. Márcio Augusto Roma Buzar. Brasília / DF, Dezembro de 2016 
Ficha catalográfica elaborada automaticamente, com os dados fornecidos pelo(a) autor(a)

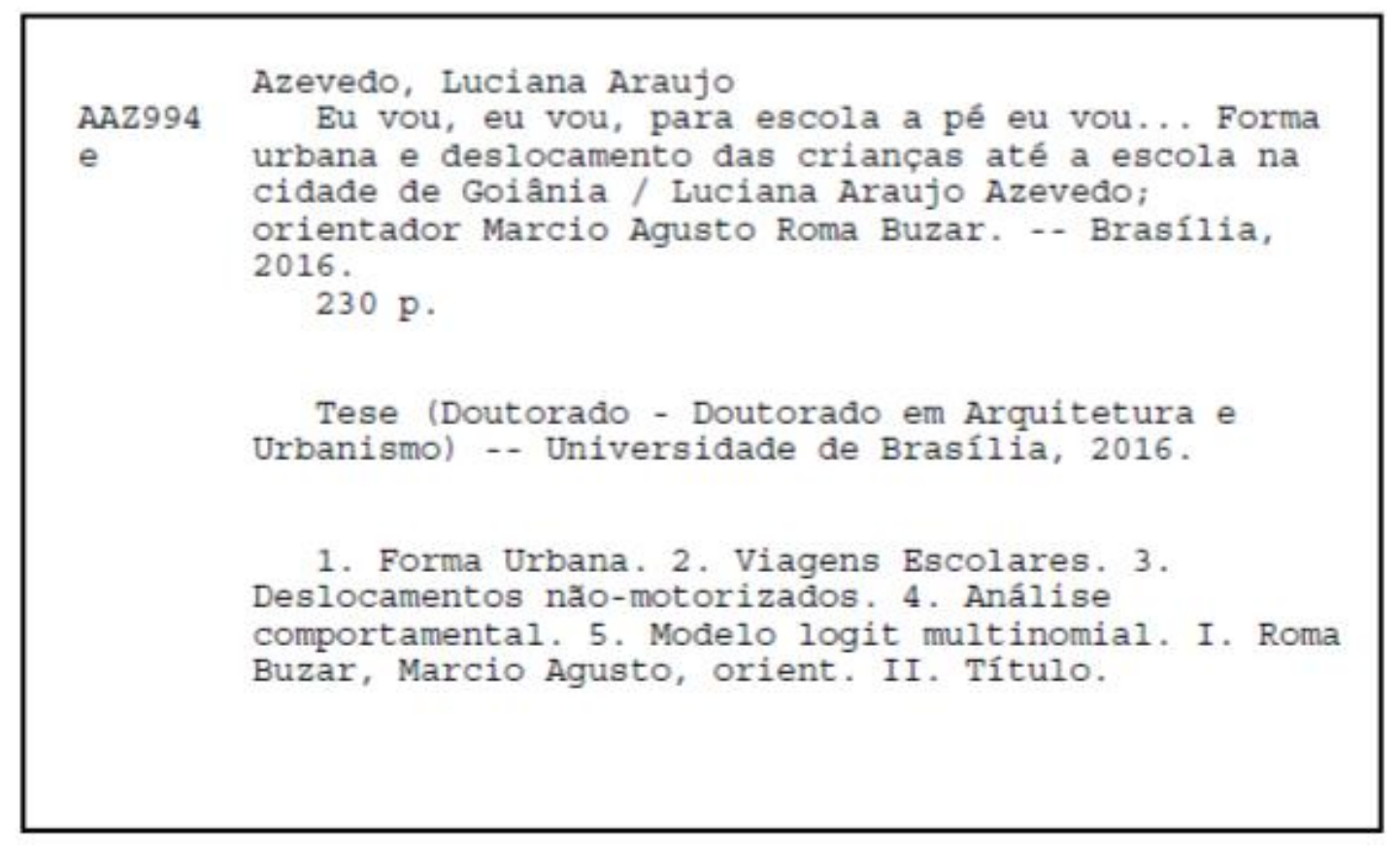

\section{REFERÊNCIA BIBLIOGRÁFICA}

AZEVÊDO, L. A. (2016) - Eu Vou, Eu Vou, Para a escola a Pé Eu Vou... Forma Urbana e Deslocamento das Crianças até a Escola na Cidade de Goiânia. Tese de Doutorado em Arquitetura e Urbanismo. Programa de Pós-Graduação da Faculdade de Arquitetura e Urbanismo da Universidade de Brasília, Brasília, DF, 230 p. 
Brasília, 16 de Dezembro de 2016

Tese de Doutorado defendida no Programa de Pós-Graduação da Faculdade de Arquitetura e Urbanismo da Universidade de Brasília e aprovada pela Banca Examinadora constituída pelos membros:

Orientador

Prof. Dr. Márcio Augusto Roma Buzar Departamento de Tecnologia da Arquitetura e Urbanismo Faculdade de Arquitetura e Urbanismo FAU-UnB

Examinador Interno

Prof. Dr. Benny Scharsberg

Departamento de Tecnologia da Arquitetura e Urbanismo Faculdade de Arquitetura e Urbanismo FAU-UnB

Examinadora Interna

Profa. Dra. Vanda Alice Garcia Zanoni

Departamento de Tecnologia da Arquitetura e Urbanismo Faculdade de Arquitetura e Urbanismo FAU-UnB

Examinadora Externa

Profa. Dra. Denise Aparecida Ribeiro Departamento de Transportes - Campus Goiânia Instituto Federal de Educação - Goiás

Examinadora Externa

Profa. Dra. Caroline Duarte Alves Gentil Departamento de Transportes - campus Jataí Instituto Federal de Educação - Goiás 


\section{Agradecimentos}

A Deus por realizar coisas grande em minha vida!!! Senhor não sou digna que entreis em minha morada, mas dizei uma só palavra e serei salva!

À minha mãe, que sempre me incentivou e lutou por mim por toda minha vida. Palavras são poucas para agradecer por tudo, pois tudo devo a senhora.

Aos meu irmãos, meus companheiros e meus primeiros amigos. Obrigada Marco Aurélio, Ana Lucia, Temistocles.

Aos meus filhos, Rayana e Daniel - Amo muito, de todo meu coração e alma. Melhor parte de mim.

Ao meu marido, companheiro de todas as horas. Obrigada por tudo, sem você não teria chegado aqui, não teria conseguido. Amor que não se mede...

Ao meu orientador Marcio Buzar, pelo auxílio e orientação.

Aos meus amigos do IFG, pela força, amizade e carinho.

Aos amigos da FAU, Vanda, Betânia, Aline, estarão sempre comigo...

Aos meus amigos do condomínio, obrigada pela compreensão das ausências...

A toda minha família, tios, primos, afilhados, compadres, amo cada um de vocês.

Ao meu querido padre João (in memorian), obrigada por ter me ensinado tantas coisas boas e lindas. Você se foi, está perto do nosso Deus, mas deixou muito de você dentro de nós.

A Julienne Santana de Morais, pela ajuda nos dados sobre transporte coletivo da cidade de Goiânia. Obrigada pela ajuda de sempre, você é demais...

Ao professor Luis Rodrigo do IME-IFG, pela ajuda na interpretação do modelo estatístico. Obrigada professor por sua disponibilidade e imensa ajuda.

Aos alunos do IFG, que me ajudaram e ajudam a ser professora...

A Capes pela ajuda financeira para conclusão da pesquisa de campo.

A todos os coordenadores e diretores das escolas municipais, estaduais e particulares da cidade de Goiânia. Esse trabalho dedico a vocês que me ajudaram a construí-lo. Obrigada pela ajuda e exemplo. Mesmo com tantas dificuldades, pude perceber em nosso convívio, como todos trabalham com dedicação e amor, fazendo da profissão de professor, um verdadeiro sacerdócio. Obrigada a todos... 


\section{Resumo}

A presente tese tem por objetivo avaliar as relações entre a forma urbana, os fatores demográficos e socioculturais, na escolha do modo de transporte das crianças até a escola, na cidade de Goiânia-GO. Através da construção de um modelo do tipo logit multinomial, buscou-se avaliar o comportamento do usuário na escolha do modo de transporte nos deslocamentos escolares. Para tanto, foram realizadas pesquisas com os pais de alunos do ensino fundamental da cidade de Goiânia. A amostra foi dividida em sete regiões administrativas (Campinas-Centro, Leste, Oeste, Norte, Sul, Noroeste e Sudoeste) por rede de ensino (estadual, municipal e particular) de forma a mensurar como algumas variáveis da forma urbana influenciam a tomada de decisão dos pais na escolha do modo de transporte até a escola. Foram estimadas as probabilidades de escolha dos usuários pelos modos de transporte disponíveis como o caminhamento, a bicicleta, o automóvel e o transporte público. As análises dos dados para a cidade de Goiânia - GO, revelaram que: 1) considerando o modo caminhamento, os resultados demonstraram uma certa influência das variáveis relacionadas à forma urbana, mais especificamente: a área do setor, o comprimento e densidade de vias, a conectividade, a largura média das calçadas e as linhas de transporte coletivo que atendem e margeiam o setor. 2) algumas variáveis relacionadas à forma urbana não tiveram um forte peso dentro da função utilidade como esperado inicialmente, entre elas, destacam-se o número total de quadras, o comprimento médio das quadras, o número e tipo de intercessões além da densidade das intercessões.

Palavras-Chave: Forma Urbana - Viagens Escolares - Deslocamentos Não Motorizados - Análise Comportamental - Modelo Logit 


\begin{abstract}
The objective of this thesis is to evaluate the relations between the urban form, demographic and sociocultural factors, on the choice of childrens means of transportation to school in the city of Goiânia. It was sought to evaluate the behavior of the user in the choice of means of transportation in school trips, through the construction of a logit multinomial model. Therefore, researches has been done with elementar school students parentes in Goiânia. The sample was divided in seven administrative regions (Campinas-Centro, Leste, Oeste, Norte, Sul, Noroeste e Sudeste), by teaching netwok (public and private), in order to measure how some of the variables oh the urban form influence the decision making of the parentes in the choice of means of transportation to the school. The probabilities of the users choice of means of transportations available is by feet, by bike, by car and public transportation were estimated. Analysis of the data fot the city of Goiania - GO revealed that: 1) considering the walking mode, the results show a certain influence of the variable related to the urban form, more specifically: the neighborhood area, the lenght and density 0 flanes, the conectivity, the averge width of the sidewalks and the public transportation lines that attends the neighborhood. 2) some variables related to the urban form did not have a strong weight in the function utility as hoped initially, between them, the total number of blocks, the average length of the blocks, the number and types of intercessions besides the density of ntercessions stands out.
\end{abstract}

Keywords: Urban Form - School Trips - Displacements Non-Motorized - Behavioral Analysis - Logit Model 


\section{Lista de Figuras}

Figura 1.1: Organização metodológica 18

Figura 3.1: Diagrama do modelo conceitual do comportamento de viagem de uma 55 criança até a escola

Figura 4.1: Modelo logit binomial $\quad 71$

Figura 4.2: Modelo logit multinomial $\quad 71$

Figura 4.3: Modelo logit aninhado $\quad 71$

Figura 4.4: Visão da tela principal do RStudio $\quad 74$

Figura 5.1: Metodologia empregada no trabalho 78

Figura 5.2: Perímetro urbano e as sete regiões administrativas de Goiânia.

Figura 5.3: Planos Atílio Corrêa Lima e Armando Godoi 81

Figura 5.4: Macrozona construída e Macrozona rural 84

Figura 5.5: Modelo espacial de Goiânia 85

Figura 5.6: Percentagens de escolas do ensino fundamental nas sete regiões $\quad 91$

administrativas de Goiânia.

Figura 5.7: Escolas pesquisadas do ensino fundamental distribuídas nas sete regiões $\quad 93$

administrativas de Goiânia

Figura 5.8: Fluxograma de Análise do Modelo Estatístico 97

Figura 6.1: Modo de transporte/região das famílias pesquisadas $\quad 104$

Figura 6.2: Modo de transporte/rede das famílias pesquisa 105

Figura 6.3: Modo de transporte na cidade de Goiânia das famílias pesquisadas $\quad 105$

Figura 6.4: Renda/região das famílias pesquisadas 106

Figura 6.5: Renda/rede das famílias pesquisadas 106

Figura 6.6: Renda na cidade de Goiânia das famílias pesquisadas 107

Figura 6.7: Número de veículos/região das famílias pesquisadas 109

Figura 6.8: Número de veículos/rede das famílias pesquisadas $\quad 110$

Figura 6.9: Número de veículos na cidade de Goiânia das famílias pesquisadas $\quad 110$

Figura 6.10: Acompanhante das crianças até a escola/região das famílias 111

pesquisadas

Figura 6.11: Acompanhante das crianças até a escola/rede das famílias pesquisadas 111

Figura 6.12: Acompanhante das crianças até a escola na cidade de Goiânia das $\quad 112$

famílias pesquisadas

Figura 6.13: Idade das crianças/região das famílias pesquisadas $\quad 113$

Figura 6.14: Idade das crianças/rede das famílias pesquisadas $\quad 113$

Figura 6.15: Idade das crianças na cidade de Goiânia das famílias pesquisadas $\quad 114$

Figura 6.16: Grau de Instrução dos pais/região das famílias pesquisadas $\quad 114$

Figura 6.17: Grau de instrução dos pais/rede das famílias pesquisadas 115

Figura 6.18: Grau de instrução dos pais na cidade de Goiânia das famílias $\quad 115$

pesquisadas

Figura 6.19: Tempo de deslocamento até a escola/região das famílias pesquisadas 116

Figura 6.20: Tempo de deslocamento até a escola/rede das famílias pesquisadas $\quad 116$

Figura 6.21: Tempo de deslocamento até a escola na cidade Goiânia das famílias $\quad 117$

pesquisadas

Figura 6.22: Influência na escolha da escola/região das famílias pesquisadas $\quad 117$

Figura 6.23: Influência na escolha da escola/rede das famílias pesquisadas 118

Figura 6.24: Influência na escolha da escola na cidade de Goiânia das famílias $\quad 118$ 
pesquisadas

Figura 6.25: Percepção dos pais quanto as variáveis da forma urbana nos

deslocamentos a pé em Goiânia

Figura 6.26: Percepção dos pais quanto as variáveis da forma urbana nos

deslocamentos por bicicleta em Goiânia

Figura 6.27: Percepção dos pais quanto as variáveis da forma urbana nos

deslocamentos por ônibus/Goiânia

Figura 6.28: Percepção dos pais quanto as variáveis moderadoras/mediadoras

deslocamentos a pé/Goiânia

Figura 6.29: Percepção dos pais quanto as variáveis moderadoras/mediadoras

deslocamentos por bicicleta/Goiânia

Figura 6.30: Percepção dos pais quanto as variáveis moderadoras/mediadoras

deslocamentos por ônibus/Goiânia

Figura 6.31: Percepção dos pais quanto à importância das variáveis forma urbana -

moderadoras - mediadoras no deslocamento a pé/Goiânia

Figura 6.32: Percepção dos pais quanto à importância das variáveis forma urbana -

moderadoras - mediadoras no deslocamento bicicleta/Goiânia

Figura 6.33 - Percepção dos pais quanto à importância das variáveis forma urbana -

moderadoras - mediadoras no deslocamento ônibus/Goiânia

Figura 6.34: \% de interseções em Cruz e T dos bairros pesquisados

Figura 6.35 - Probabilidade de escolha dos modos - Goiânia

Figura 6.36 - Probabilidade de escolha dos modos - Goiânia 


\section{Lista de Tabelas}

Tabela 2.1: Dimensões da forma urbana 27

Tabela 2.2: Relação das dimensões e seus elementos na estrutura urbana 32

Tabela 2.3: Relação das dimensões e seus elementos na estrutura urbana 33

Tabela 2.4 - Faixas de Serviço - Livre - Acesso às calçadas (Goiânia) 38

Tabela 5.1: Evolução da população de Goiânia - 1940 - 2010

Tabela 5.2: Total de Estabelecimentos de Ensino e Sala de Aula por tipo de vínculo - $\quad 88$

Goiânia 2010 - 2012

Tabela 5.3: Total de Estabelecimento de Ensino e Número de Escolas e Alunos 89

matriculados no Ensino Fundamental em Goiânia

Tabela 5.4: Total de Escolas do Ensino Fundamental por Região Administrativa 89

Tabela 5.5: Total de Alunos Matriculados do Ensino Fundamental por R.A 90

Tabela 5.6: Forma de Coleta das Variáveis da Forma Urbana dos Bairros 96

Pesquisados

Tabela 5.7: Resultados do Processamento Completo - R-Studio® 98

Tabela 6.1: Variáveis da forma urbana - bairros de Goiânia pesquisados 126

Tabela 6.2: Resultados do processamento completo - R-Studio® 130

Tabela 6.3: Variáveis do modelo completo - R-Studio®

Tabela 6.4: Variáveis de forma urbana avaliadas de maneira independente R-Studio® 131

Tabela 6.5: Resultados do processamento independente - R-Studio® 


\section{SUMÁRIO}

1.INTRODUÇÃO 14

1.1 Considerações iniciais 14

1.2.Objetivos 16

1.2.1 Objetivos gerais 16

1.2.2 Objetivos específicos 16

$\begin{array}{ll}1.3 \text { Justificativa } & 17\end{array}$

1.4 Metodologia utilizada 18

1.5 Originalidade e relevância da tese 20

1.6 Estrutura do trabalho 20

2. FORMA URBANA E DESLOCAMENTOS NÃO MOTORIZADOS 23

2.1 Forma Urbana, ambiente construído e comportamento de viagens 23

2.2 Variáveis que caracterizam a forma urbana 27

2.2.1 Densidade 28

2.2.2 Diversidade 30

2.2.3 Desenho Urbano 31

2.2.4 Disponibilidade de transporte coletivo 40

2.3 Estudos relacionam forma urbana e deslocamentos não motorizados 41

2.4 Tópicos conclusivos 46

3. VIAGENS ESCOLARES DAS CRIANÇAS 49

3.1 Comportamento das viagens das crianças até a escola 49

3.2 Questão multidisciplinar 51

3.2.1 Transportes 51

3.2.2 Saúde 52

3.3 Fatores que influenciam as viagens das crianças até a escola 54

3.3.1 Fatores mediadores 56

3.3.2 Fatores moderados 58

3.4 Estudos que relacionam deslocamento das crianças e forma urbana 60

3.4 Tópicos conclusivos 63

4. MODELOS PARA ANÁLISE COMPORTAMENTAL 67

4.1 Bases teóricas sobre modelos $\quad 67$

4.2 Características do modelo de escolha discreta 69 
4.2.1 Tipos de modelo de escolha discreta 70

4.3 Modelo de regressão logística multinomial $\quad 72$

4.4 O software RStudio $\quad 73$

4.5 Tópicos conclusivos $\quad 74$

5. ASPECTOS METODOLÓGICOS

5.1 Metodologia utilizada $\quad 77$

5.2 Delimitação da área de estudo $\quad 79$

$\begin{array}{lll}\text { 5.2.1 Sobre a cidade de Goiânia } & 80\end{array}$

5.2.2 Estatística e amostra da pesquisa 87

$\begin{array}{ll}\text { 5.3 Dados coletados com os pais } & 94\end{array}$

5.4 Dados coletados variáveis da forma urbana $\quad 95$

5.5 O Modelo multinomial para a escolha dos diferentes modos 97

5.5.1 Cálculo das utilidades e probabilidades da função resposta 99

5.6 Tópicos conclusivos 101

6. RESULTADOS OBTIDOS 103

$\begin{array}{ll}\text { 6.1 Resultados da pesquisa com os pais } & 103\end{array}$

6.2 Resultados obtidos sobre a percepção dos pais quanto à importância das variáveis forma urbana assim como as variáveis moderadoras e 119 mediadoras nas viagens escolares em Goiânia

6.3 Resultados do levantamento da forma urbana 126

6.4 Resultados sobre as escolhas dos diferentes modos 129

6.4 Tópicos conclusivos 140

7. CONCLUSÕES E SUGESTÕES PARA TRABALHOS FUTUROS 143

7.1 CONCLUSÕES 143

7.2 SUGESTOES PARA TRABALHOS FUTUROS 145

REFERÊNCIAS BIBLIOGRÁFICAS 146

ANEXO A 156

$\begin{array}{ll}\text { ANEXO B } & 164\end{array}$ 


\section{Introdução}




\subsection{INTRODUÇÃO}

\subsection{CONSIDERAÇÕES INICIAIS}

A concentração da população em áreas urbanas e o espalhamento das cidades, nas últimas décadas, causaram um comprometimento dos serviços de transporte público, problemas ambientais e a consequente degradação da qualidade de vida. Essa expansão urbana para as áreas periféricas das cidades favorece o espalhamento das atividades urbanas, tornando a população dependente do uso dos modos de transporte motorizados, essencialmente o modo motorizado individual, devido a suas facilidades de locomoção e conforto.

As maiores cidades do Brasil, tal como ocorre em muitos outros países em desenvolvimento, foram transformadas, em décadas recentes, em espaços eficientes para o automóvel. A frota de automóveis cresceu substancialmente, alardeada como única alternativa eficiente de transporte para os cidadãos de mais elevados níveis de renda. O sistema viário sofreu ampliações e adaptações, órgãos públicos foram implantados para se garantir boas condições de fluidez para o automóvel, e a cultura voltada para o veículo individual foi implantada na vida dos cidadãos brasileiros.

O deslocamento a pé vem sendo reduzidos e sendo substituídos pelos modos motorizados, desde a Revolução Industrial. Os espaços urbanos são, muitas vezes, concebidos à infraestrutura de vias, sob um pensamento errôneo de sustentar as viagens realizadas por carro, que obteve um crescimento de $104,5 \%$ entre os anos de 2001 a 2012 no Brasil, DENATRAN (2013). Por outro lado, a infraestrutura pedonal e

cicloviária fica negligenciada ou em segundo plano. É neste contexto que a maioria das cidades perde espaço para a escala humana e toma para si a escala motorizada, deixando, portanto, de proporcionar uma vida urbana mais agradável, cujas cidades sejam para pessoas e não para veículos. GEHL (2010).

Segundo Handy et al. (2002), as viagens a pé oferecem vários benefícios para uma comunidade, incluindo economia nos custos do transporte, melhoria na qualidade de vida, redução dos impactos ambientais, maior equidade de acesso às atividades urbanas, etc. Apesar de fornecerem todos estes benefícios, as viagens a pé, assim como as viagens por bicicleta, são muitas vezes negligenciadas nos planejamentos de transportes e as administrações públicas geralmente não valorizam os espaços para pedestres ou ciclistas. Além disso, as viagens curtas, as viagens de recreação ou 
turismo e as viagens realizadas por crianças, são geralmente, desprezadas nos levantamentos de demanda de viagens.

Muitos fatores influenciam os deslocamentos das pessoas nas cidades, como, por exemplo, idade, renda, sexo, habilidade motora, capacidade de entendimento de mensagens e restrições de capacidades individuais. BRASIL (2007). Além desses fatores, muitas pesquisas sobre os Sistemas de Transporte estão focando suas análises na escala micro territorial, e procuram descrever em escala humana, em nível de bairro ou setores vizinhos, como as características do ambiente construído podem estimular ou dificultar a realização de viagens pelo modo a pé. FHWA (2000).

Os deslocamentos diários realizados a pé ou de bicicleta para ir ao trabalho ou escola, constituem uma associação positiva na saúde em geral das pessoas. Segundo Pont et al. (2009), crianças e adolescentes que utilizam o transporte não motorizado até a escola, são fisicamente mais ativos, tem níveis mais elevados de gastos energéticos e tem uma maior probabilidade de praticarem atividade física quando adultos, do que aqueles que se deslocam de maneira passiva. Nos EUA há uma forte preocupação com o estilo de vida das crianças, já que o índice de obesidade infantil aumentou $20 \%$ nos últimos 10 anos.

Segundo Mcdonald (2005), a forma como as crianças viajam até a escola nos EUA, mudou radicalmente. Em 1969, 42\% dos estudantes caminharam ou pedalaram até a escola; em 2005, esse percentual baixou para 13\%. As mudanças nas viagens escolares são importantes, pois $50 \%$ das viagens realizadas pelas crianças, de segunda a sexta-feira durante o ano letivo são para a escola.

Essa mudança não é uma questão apenas de saúde, mas influencia sobremaneira o planejamento de transportes. Uma melhor compreensão das viagens das crianças se faz necessário para um maior entendimento das viagens dos adultos. Segundo Handy (1996), em uma pesquisa sobre viagens não motorizadas e desenho urbano, a acessibilidade de infraestruturas para pedestres (com foco em presença, qualidade, distância de viagem, opções de rotas) está positivamente associada com o comportamento de caminhar. No caso das crianças, Diguiseppi et.al.(1998), afirma ser as distâncias entre a casa e a escola, uma das maiores barreiras para caminhar ou andar de bicicleta. 
Dessa forma, pode-se dizer que os elementos ligados à forma urbana, como: o sistema viário, estrutura fundiária, espaços verdes e abertos, densidades de habitação, aspectos dos mobiliários urbanos e calçadas, estes definidos na legislação, como a lei do plano diretor e lei de uso e ocupação do solo, caracterizando formas urbanas diferenciadas, podem propiciar condições maiores ou menores ao deslocamento a pé ou de bicicleta às pessoas, influenciando na escolha do modo de transporte.

Esta tese pretende analisar a natureza e o modo da relação entre a forma urbana e fatores pessoais, demográficos e social/cultural na tomada de decisão dos pais sobre a viagem dos filhos até a escola. Através de uma pesquisa realizada com pais em escolas do ensino fundamental de Goiânia, avaliou-se a influência da forma urbana na escolha do modo de transporte até a escola.

Os procedimentos utilizados na pesquisa têm por finalidade identificar os fatores que influenciam na escolha do modo de transporte das crianças até a escola. Para atingir os objetivos desta tese, utilizou-se o modelo proposto por Handy (1996) e aprofundado por Mcmillan (2003). Dessa forma, a presente pesquisa se concentrou em identificar a relação entre a forma urbana e o comportamento das viagens das crianças até a escola incluindo a identificação e a compreensão de múltiplos fatores que não são da forma urbana, no entanto influenciam tal deslocamento.

\subsection{OBJETIVOS}

\subsubsection{Objetivos Gerais}

O objetivo desta tese é avaliar a relação entre a forma urbana, fatores demográficos e socioculturais, na escolha do modo de transporte das crianças até a escola, na cidade de Goiânia.

\subsubsection{Objetivos Específicos}

a) analisar dentre os elementos da forma urbana, variáveis demográficas e socioculturais, quais efetivamente afetam a escolha do modo de transporte até a escola;

b) avaliar através de um modelo comportamental do tipo logit multinomial as variáveis que influenciam na decisão dos pais sobre a escolha do tipo de modo de deslocamento até a escola (variáveis da forma urbana e fatores moderadores/mediadores). 


\section{3 - JUSTIFICATIVA}

Estudos do comportamento de viagem das crianças são recentes na literatura, especialmente as viagens escolares. A viagem de uma criança até a escola é tanto complexa quanto importante, pois o deslocamento de toda família é influenciado sobremaneira pelos deslocamentos dos filhos.

Em todo mundo têm-se verificado um declínio nos deslocamentos a pé ou a bicicleta, em detrimento ao modo motorizado. Como exemplo, nos EUA, o aumento da obesidade infantil tem ocorrido ao mesmo tempo em que as crianças mudaram radicalmente seu modo de chegar até a escola. Estudos recentes têm mostrado que crianças que utilizam modos ativos de transporte até a escola (a pé/bicicleta) é provável que sejam mais ativos fisicamente durante outros períodos do dia, bem como, tem seu estado físico e mental aumentado. TUDOR-LOCKE et al. (2001).

Segundo Mcmillan (2003), as verdadeiras causas dessas mudanças no comportamento de viagem escolares ainda não são conhecidas. Porém, estudiosos de planejamento urbano atribuíram tal mudança a forma urbana de nossas comunidades. Segundo esta hipótese, elementos básicos como: aumento no comprimento de blocos ou quadras, maior largura das ruas e diminuição da presença de calçadas em comunidades levaram à diminuição da caminhada e do uso de bicicleta por crianças, causando impactos negativos a longo prazo sobre o transporte e a saúde pública.

O tráfego gerado em razão do funcionamento das escolas provoca congestionamentos em áreas residenciais, aumenta as emissões de carbono e faz com que a área ao redor dessas escolas não seja segura para as crianças. A realidade aponta para 0 aumento dos carros estacionados, de vans escolares e a dependência do uso do carro individual que conduzem a problemas de saúde, onde podem ser incluídos: saúde pessoal (por exemplo, através do aumento dos níveis de obesidade; meio ambiente (devido à deterioração da qualidade do ar, e aumento do nível de $\mathrm{CO}_{2}$ e sobre o tráfego devido aos congestionamentos. PIKE (2003).

Segundo Pont et al. (2009), existem muitos fatores que influenciam a escolha do modo de transporte das crianças até a escola. Segundo uma vasta revisão literária dos autores sobre o assunto, as variáveis mais influentes são: distância casa-escola, 
atributos socioeconômicos, características do ambiente construído e percepções dos pais ou responsáveis sobre a segurança da vizinhança e condição do tráfego de veículos no caminho até a escola.

No entanto, os estudos sobre forma urbana e o comportamento de viagem das crianças tem em sua maioria seguido duas vertentes: a construção de modelos para prever a demanda de viagens e as pesquisas empíricas, que buscam identificar os elementos que afetam o comportamento da viagem, sendo que a maior parte dessas pesquisas onde são relacionados o ambiente construído e a escolha do modo, se concentra mais especificamente em adultos.

O tema dessa tese justifica-se pelo fato de caracterizar o relacionamento entre forma urbana e o comportamento de viagens escolares de crianças entre 6-14 anos, incluindo a identificação de outros fatores que influenciam a decisão dos pais sobre o deslocamento dos filhos. Esse estudo propõe que existem múltiplos fatores que influenciam na decisão de como fazer a viagem para a escola. $O$ entendimento de como esses fatores se relaciona, vai ajudar no desenvolvimento e planejamento de políticas públicas mais eficazes.

\subsection{METODOLOGIA UTILIZADA}

As etapas de organização metodológica estão sintetizadas na figura 1.1:

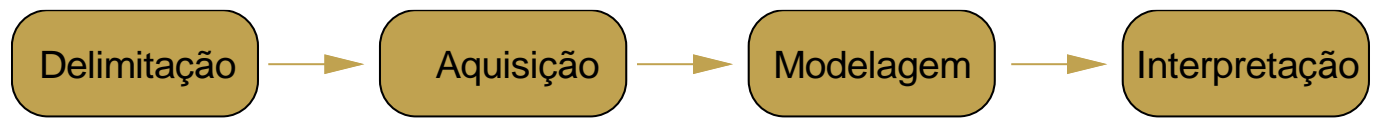

Figura 1.1 - Organização Metodológica

Na etapa de delimitacão explorou-se a caracterização da cidade que constitui o objeto de estudo, a cidade de Goiânia. Iniciou-se a investigação e interpretação de toda estrutura urbana da cidade. A partir desse estudo a cidade foi dividida em sete regiões administrativas (utilizada pela prefeitura da cidade) a saber: Norte, CentroCampinas, Leste, Oeste, Noroeste, Sul e Sudoeste. Foi realizada uma pesquisa com os pais dos alunos do ensino fundamental da cidade, que estudam nas redes estadual, municipal e federal. Foram realizados procedimentos estatísticos de amostragem da população, mostrados no capítulo 4 desta Tese. Nessa etapa foram levantadas as variáveis que, segundo HANDY et al (2002) permitem aferir as características do desenho urbano. Foram exploradas as seguintes: 
- A conectividade viária;

- A escala viária;

- A qualidade estética;

- Os dados do transporte urbano nos bairros das escolas estudadas.

Destaca-se a importância da etapa de Delimitação pois serve de subsídio para identificação das variáveis que compõe o questionário o qual foi aplicado aos pais das crianças.

No que tange a Aquisição, essa fase diz respeito à coleta de dados que serviu para abastecer os modelos estatísticos integrantes da etapa posterior. Realizou-se nessa etapa:

- $\quad$ aplicação de um questionário aos pais das crianças matriculadas em escolas dos bairros que foram selecionados na etapa de delimitação;

- o levantamento in loco e com ajuda de mapas georefenciados da cidade de Goiânia, definidas na etapa anterior de avaliação do desenho urbano.

Na Modelagem optou-se por utilizar um modelo de escolha discreta multinominal do tipo Logit processado no software Rstudio $\AA$, uma plataforma gratuita (freeware), utilizando-se de modelos de otimização para a estimação dos valores mínimos da função de utilidade, o software faz a maximização da função, escolhendo dentre as várias alternativas possíveis àqueles cujos atributos proporcionem o maior nível de satisfação ao indivíduo.

Por fim faz-se a interpretacão que consiste na análise dos resultados e avaliação das variáveis da forma urbana e outras variáveis que não são da forma urbana mas influenciam a tomada de decisão dos pais quanto a escolha do modo de transporte até a escola. 


\subsection{ORIGINALIDADE E RELEVÂNCIA DA PESQUISA}

De acordo com a literatura, o desenvolvimento de modelos comportamentais tem sido estimulado por vários grupos de pesquisadores. Grande parte dos trabalhos realizados para verificação da análise comportamental estuda as viagens realizadas por adultos, negligenciando os deslocamentos das crianças.

A originalidade do trabalho se dá na possibilidade de incorporar variáveis da forma urbana nos modelos comportamentais objetivando prever as relações entre as viagens escolares e a forma urbana em uma cidade brasileira, utilizando para isso modelos multinomiais. A relevância dessa pesquisa está em formular e estimar um modelo comportamental de escolha discreta do tipo Logit Multinomial, considerando a relação entre forma urbana e a escolha do modo de viagem realizada por crianças do ensino fundamental na cidade de Goiânia.

\subsection{ESTRUTURA DO TRABALHO}

A presente tese foi estruturada em sete capítulos que abrangem desde os fundamentos teóricos necessários para o desenvolvimento do trabalho até a avaliação dos resultados e as conclusões finais. No capítulo 1 são abordadas as considerações iniciais da pesquisa, os objetivos gerais e específicos, a justificativa do trabalho e a organização metodológica. Nesta primeira etapa destaca-se também a originalidade e relevância do trabalho.

O capítulo 2 dedica-se a explorar os conceitos referentes à forma urbana e os deslocamentos não motorizados. Procura-se descrever os fundamentos teóricos sobre o planejamento de transportes e a forma urbana destacando algumas variáveis relacionadas como a densidade, a diversidade, o desenho urbano e a disponibilidade do transporte coletivo. Constitui-se a base teórica necessária ao desenvolvimento do trabalho.

As viagens escolares das crianças e suas características são abordadas no capítulo 3 . Destacam-se os fatores mediadores e moderados que não são variáveis da forma urbana, mas que influenciam a tomada de decisão dos pais quanto as viagens escolares das crianças. Apresenta-se dois modelos que tratam da estrutura das 
viagens segundo Macmilan e Handy. O estudo destes trabalhos já consagrados na literatura serviu de base para a elaboração do modelo específico utilizado na cidade de Goiânia que representa o principal propósito da presente tese.

O capítulo 4 dedica-se a explorar os modelos existentes para a análise comportamental. São apresentadas as bases teóricas dos principais modelos utilizados dedicando-se, principalmente, aos modelos de escolha discreta. O modelo de regressão logística multinomial, bastante explorado na pesquisa, é também pormenorizado neste capítulo.

Os aspectos metodológicos utilizados para o levantamento dos resultados foram abordados no capítulo 5, onde é apresentada a cidade de Goiânia como estudo de caso. Nesse capítulo é exibida as características das regiões administrativas estudadas, a análise exploratória dos dados obtidos principalmente sobre os modais utilizados na condução das crianças até a escola. No capítulo 6, apresenta-se a análise dos resultados com o cálculo das utilidades e probabilidades que definem o modo de escolha por parte dos adultos e os fatores que influenciam na tomada de decisão. O capítulo 7 apresenta as conclusões e sugestões para trabalhos futuros. 
Forma Urbana e os Deslocamentos

Não Motorizados 


\subsection{FORMA URBANA E DESLOCAMENTOS NÃO MOTORIZADOS}

\subsection{FORMA URBANA, AMBIENTE CONSTRUÍDO E COMPORTAMENTO DE VIAGENS}

Nos últimos anos nota-se que a forma de viajar dos brasileiros mudou significativamente. Devido à expansão urbana e espalhamento das atividades, a população se tornou dependente dos meios motorizados de transporte, principalmente o individual, cujo apelo principal refere-se à sua facilidade de locomoção e o conforto. O número de pessoas nas cidades aumentou em demasiado nas últimas décadas. Segundo Vasconcellos (2014), o número de pessoas nas cidades aumentou significativamente e na segunda metade do século XX, a população urbana passou de 19 milhões para 138 milhões, multiplicando-se 7,3 vezes, com uma taxa média anual de crescimento de 4,1\%. Ou seja, a cada ano, em média, mais de 2,3 milhões de habitantes foram acrescidos à população urbana.

Ao longo desse período, não houve uma política consistente de desenvolvimento urbano no Brasil. Na falta de uma legislação eficiente do Estado na regulação dos conflitos de uso e ocupação do solo, grupos sociais de baixa, média e alta renda usaram estratégias para gerar o novo espaço urbano que Ihes interessava. Esse processo gerou de um lado renovações urbanas em áreas mais centrais (onde se localizou a classe média), empreendimentos distantes da área central e bem definidos espacialmente (onde se localizou a classe de renda alta), impactando a mobilidade na medida em que os novos moradores tornaram-se cativos do modo individual para a maioria dos seus deslocamentos. (VASCONCELLOS, 2014)

Muitos autores atribuem o aumento do uso do automóvel à cultura do consumismo e do status da população que vivem nos centros urbanos. Nesse ritmo de crescimento dos deslocamentos realizados por veículos individuais, aumentam os investimentos na implantação de uma infraestrutura viária voltada para o "carro" - as ciclovias e a infraestrutura pedonal são esquecidas e por vezes não constam nos projetos de urbanização. Nesse cenário, as cidades doam espaço para escala motorizada e perdem espaço para a escala humana.

Estudos de Jacobs (2000) indicam que os espaços nas cidades estão se transformando e "estranhamente" cedendo lugar ao automóvel e essa transformação das grandes cidades devido principalmente ao aumento da motorização, influencia de 
maneira negativa os espaços urbanos e as relações sociais. A dimensão humana deu lugar aos veículos motorizados.

De acordo com Gehl \& Svarre (2013) observou a vida na cidade, "tão natural" durante décadas, não recebia a devida atenção e pouco se estudava o impacto de sua constante deterioração. Os efeitos da substituição das pessoas pelo tráfego de veículos são assoladores e os espaços urbanos são cada vez mais dos carros e os problemas de poluição gerada por esses veículos, aumentam os riscos de doenças respiratórias, além de causar prejuízos financeiros aos cofres públicos.

No que tange a arquitetura, estudos que contemplam a natureza social, econômica e política do espaço têm sido desenvolvidos, especialmente nas últimas décadas. Todavia, ainda falta um aprofundamento preciso quanto à articulação da cidade em termos de hierarquias e permeabilidades; e como esses fatores diretamente relacionados à forma ilustram o estado atual das cidades no Brasil e no mundo, e seus associados processos de expansão urbana.

O WORLD BANK (2002) apud Amancio (2005), identifica a necessidade de ênfase em políticas e instrumentos relacionados à ocupação urbana, que influenciem a escolha modal, beneficiando o transporte coletivo e os transportes não motorizados. A operacionalização desta ênfase depende de um melhor entendimento do relacionamento entre a forma urbana e o comportamento de viagens nos países em desenvolvimento.

Segundo Banister (2008), existem evidências que o ambiente construído exerce influência sobre os padrões de deslocamento das pessoas, mesmo que alguns pesquisadores sejam contrários quanto à possibilidade das características da forma urbana poder afetar a demanda por transportes.

Os modelos de escolha modal que relacionam as características do ambiente construído e sua influência no comportamento de viagem objetivam alcançar uma diminuição na quantidade de viagens motorizadas individuais a partir do aumento na participação das viagens não motorizadas (a pé, bicicleta) e do transporte coletivo. Dentre os modos de transporte, os não motorizados (a pé e bicicleta) são os menos danosos a vida urbana, por serem não poluentes e por não consumirem combustíveis fósseis. Entretanto, os planos e projetos de transportes ignoram a existência de bicicletas e pedestres. Além disso, poucos dados têm sido coletados sobre transportes 
não motorizados e os fatores que influenciam as pessoas a optarem por andar a pé ou a utilizarem a bicicleta como meio de transporte (AMÂNCIO, 2008).

Segundo Ferraz (1998), o transporte coletivo é um serviço essencial nas cidades e desenvolve papel social e econômico de grande importância, pois democratiza a mobilidade, na medida em que facilita a locomoção das pessoas. O mesmo constitui um modo de transporte imprescindível para reduzir os congestionamentos, diminui os níveis de poluição e o minimiza uso indiscriminado de energia automotiva.

Entre os diversos fatores importantes para o bom desempenho do sistema de transporte urbano estão as características urbanas que constituem o que se conhece na literatura como forma urbana, as quais influenciam diretamente no comportamento de viagem das pessoas. As características do meio físico urbano desempenham um papel importante nas escolhas modais individuais de transportes, agindo frequentemente como uma restrição nas alternativas que poderiam estar disponíveis. (AMANCIO, 2005)

De acondo com Frank e Pivo (1994) a forma urbana refere-se a distribuição das atividades dentro do sistema urbano. Segundo os autores, a densidade populacional, a densidade de empregos, a diversidade de usos do solo e o mix entre moradias e locais de trabalho são as quatro variáveis primárias com as quais o comportamento de viagem tem sido mais correlacionado. O termo "Forma Urbana" foi expandido por Handy (1996a), que tratou de uma forma mais ampla as questões relacionadas ao "uso do solo". Segundo essa nova abordagem, além dos padrões do uso do solo, os aspectos do desenho urbano e as características do sistema de transporte fazem parte de uma mesma estrutura da forma urbana.

Segundo Handy et al. (2002) padrão de uso do solo diz respeito à "distribuição de atividades ao longo do espaço, incluindo a localização e densidade de diferentes atividades, onde atividades estão agrupadas em categorias mais amplas como residencial, comercial, industrial, e outras atividades" e é "preocupado com a função e apelo de espaços públicos". Já o desenho urbano "é o desenho da cidade" e os elementos físicos inseridos nele, incluindo o seu arranjo e aparência, refere-se a infraestrutura física de estradas, calçadas, ciclovias, ferrovias, pontes, etc, bem como o nível de serviço ofertado pelo fluxo de tráfego, frequência e oferta do transporte público e similares. 
Segundo Cervero (2002), a relação entre o ambiente construído e as mudanças no comportamento da demanda por transporte é um tema que vem sendo investigado e explorado por pesquisadores nos últimos anos. Planejadores urbanos têm estudado outros conceitos conhecidos por New Urbanism, Friendly Neighborhoods e Transit Oriented Development (TOD), visando promover formas urbanas cujos atributos incentivem o uso de modos de transportes alternativos ao automóvel particular.

O New Urbanism é um movimento internacional que visa novas estratégias para reformular o desenho do ambiente construído, visando aumentar a qualidade de vida das pessoas, e busca articular características específicas de desenho das redes de transporte público, redes de calçadas e caminhos interconectados, grandes espaços públicos e redução do uso do automóvel. Em sintese o movimento têm por objetivo:

- Melhorar a capacidade de realizar viagens a pé (walkability);

- Conectividade para o pedestre e usuário do transporte público;

- Uso misto do solo;

- Diversidade, incluindo pessoas de idades, níveis culturais e sociais distintos;

- Padrões de residência mistos;

- Qualidade arquitetônica e desenho urbano;

- Estrutura de vizinhança tradicional, com um centro comercial, espaços públicos, diversidade de usos à 10 minutos a pé;

- Aumento na densidade;

- Transporte inteligente (smart transportation), conectando cidades e bairros que tenham uma relação consolidada;

- Sustentabilidade;

- Qualidade de vida.

A presente tese sustenta-se na premissa de que a partir do entendimento de como se dão as relações entre as características urbanas e o comportamento dos pais em relação às viagens escolares de seus filhos, é possível propor medidas que tenham como objetivo a diminuição da priorização e dependência do transporte particular e estimular o uso de transportes mais sustentáveis como o caminhamento, o uso da bicicleta e do transporte público urbano. 


\subsection{VARIÁVEIS QUE CARACTERIZAM A FORMA URBANA}

$\mathrm{Na}$ literatura são encontradas várias maneiras de caracterizar a influência da forma urbana sobre o comportamento de viagem, inclusive os dados podem ser calculados dentro de zonas como as censitárias, zonas de tráfego e de uma forma mais desagregada, considerando a residência do indivíduo.

Tabela 2.1 - Dimensões da forma urbana

\begin{tabular}{|c|c|c|}
\hline Dimensão & Definição & Exemplo e Medidas \\
\hline $\begin{array}{l}\text { 1.Densidade e Intensidade do } \\
\text { desenvolvimento }\end{array}$ & $\begin{array}{l}\text { Quantidade de atividade em uma dada } \\
\text { área }\end{array}$ & $\begin{array}{l}\text { - Pessoas/área; } \\
\text { - № Empregos/área; } \\
\text { - Proporção de espaço } \\
\text { construído em relação à } \\
\text { área total do terreno. }\end{array}$ \\
\hline 2. Uso misto do solo & $\begin{array}{l}\text { Proximidade de diferentes cate- } \\
\text { gorias de uso do solo. }\end{array}$ & $\begin{array}{l}\text { - Distância da residência ao } \\
\text { comércio mais próximo; } \\
\text { - Parcela total da área do } \\
\text { terreno adotado para } \\
\text { diferentes usos; } \\
\text { - Indice de dissimiliridade. }\end{array}$ \\
\hline 3.Conectividade viária & $\begin{array}{l}\text { Disponibilidade e lineariedade } \\
\text { de rotas alternativas ao longo } \\
\text { da rede }\end{array}$ & $\begin{array}{l}\text { - Interseções } / \mathrm{Km}^{2} \\
\text { - Proporção de distância em } \\
\text { linha reta da distância na } \\
\text { rede; } \\
\text { - Extensão média de uma } \\
\text { quadra. }\end{array}$ \\
\hline 4. Escala Viária & $\begin{array}{l}\text { Espaço tridimensional ao lon- } \\
\text { go de uma via enquanto limi- } \\
\text { tado por edifícios. }\end{array}$ & $\begin{array}{l}\text { - Proporções das alturas dos } \\
\text { edifícios em relação à } \\
\text { largura da via; } \\
\text { - Distância média da rua aos } \\
\text { prédios }\end{array}$ \\
\hline 5. Qualidades Estéticas & Atratividade e apelo de um local & $\begin{array}{l}\text { - Percentual de terreno à } \\
\text { sombra ao meio dia; } \\
\text { - No e locais com pixações; } \\
\text { - Percepções paisagísticas } \\
\text { de um local; } \\
\text { - Qualidade de espaço para } \\
\text { pedestres. }\end{array}$ \\
\hline
\end{tabular}

Fonte: Handy et al (2002) 
Um dos primeiros e mais importantes estudos dessa linha é o trabalho de Cervero e Kockelman (1997). Neste trabalho, os autores definiram os "3D", Densidade (density), Diversidade (diversity) e Desenho (design), como as três principais dimensões do ambiente construído com impacto sobre as viagens. Handy et al. (2002) definiu cinco dimensões da forma urbana medidas nessas escalas geográficas que constitui a densidade e intensidade de desenvolvimento, o uso misto do solo, a conectividade viária, a escala viária e a qualidade estética, que podem ser visualizadas na tabela 2.1.

Moudon et al. (2006) citam que as variáveis do ambiente construído que mais explicam as condições de caminhabilidade (walkability) são: maior densidade, proximidade de distintas atividades e quadras de tamanhos reduzidos. Nesse contexto, trabalhos como Cervero e Kockelman (1997), Cervero e Duncan (2003) e Krizek (2003) contemplaram três principais dimensões influenciando a realização de viagens: densidade, diversidade e desenho urbano. Outras duas dimensões foram incluídas posteriormente: o destino acessível e a disponibilidade de transporte público.

Conforme Rocha et al. (2012) apud Rodrigues et al. (2013), a densidade é a intensidade do uso do solo em termos de habitação, emprego e outras atividades em determinada área; a diversidade reflete a heterogeneidade do uso do solo e interfere na proximidade das atividades. O desenho urbano refere-se à qualidade e à configuração física da malha viária, influenciando na continuidade e na conectividade da rede de caminhos dos pedestres; destino acessível compreende o tipo e quantidade de atividades e oportunidades disponíveis em seu entorno e a disponibilidade de transporte público é obtida pela acessibilidade ao mesmo.

\subsubsection{Densidade}

Uma diversidade de pesquisas realizadas sobre características da forma urbana e comportamento de viagem revelam que bairros com altas densidades populacionais a percentagem de viagens realizadas por carro individual é menor e a própria configuração urbana incentiva a realização de viagens utilizando modos não motorizados. Esse fato acontece, devido nesses bairros existir uma maior concentração tanto de atividades comerciais quanto residenciais propiciando uma menor distância a ser percorrida entre as origens e os destinos das viagens, facilitando aquelas não motorizadas. 
Segundo Cervero e Kockelman (1997) os bairros relativamente densos tendem a ter quadras curtas, padrão viário em formato de grelha e uma rede de calçadas, além de estarem associados à oferta limitada de estacionamento, maior intensidade de serviço de transporte coletivo e mistura de usos do solo.

Por ser uma variável cujos dados são de fácil levantamento (normalmente as informações podem ser obtidas de órgãos públicos de estatística), essa variável é bastante utilizada por pesquisadores para descrever a forma urbana. BOARNET \& CRANE (2001)

Existem inúmeras formas de se representar a densidade urbana, aqui será apresentada as três principais, e que aparecem em: AMÂNCIO (2005); FRANK \& PIVO (1994); BOARNET \& CRANE (2001); CERVERO \& KOCKELMAN (1997). A densidade populacional é calculada como:

$$
D P i=\frac{P T i}{A T i}
$$

Onde:

$D P i=$ densidade populacional no bairro i (habitantes por hectares);

$P i=$ população total do bairro i (número de habitantes);

$A T i=$ área total do bairro $\mathrm{i}(\mathrm{ha})$.

Já a densidade residencial é definida como:

$$
D R i=\frac{R T i}{A T i}
$$

Onde:

$D R i=$ densidade residencial no bairro i (residências por hectare);

$R T i=$ número total de residências no bairro $\mathrm{i}$;

$A T i=$ área total do bairro $\mathrm{i}(\mathrm{ha})$.

A percentagem de ocupação é dada por:

$$
P O i=\frac{A T C i}{A T i}
$$


Onde:

$P O i=$ percentagem de ocupação do bairro i;

$A T C \mathrm{i}=$ área total construída no bairro i (ha);

$A T i=$ área total do bairro $\mathrm{i}(\mathrm{ha})$.

\subsubsection{Diversidade}

Segundo Handy et al (2002) apud Takano (2010) a diversidade de uso do solo é definida como a relativa proximidade de diferentes tipos e uso do solo dentro de uma área sob análise e pressupõe-se que a combinação de diferentes usos compatíveis e próximos entre si diminui a distância entre origens e destinos das viagens.

Para determinar a diversidade de usos do solo ou a mistura de usos em uma determinada área, os pesquisadores empregam metodologias variadas cujo objetivo é apresentar um índice (quantitativo) de diversidade de usos que represente a realidade local. Neste trabalho será utilizado o índice de entropia, medida também utilizada em outros trabalhos como: ARRUDA (2000); CERVERO \& HOCKELMAN (1987); FRANK \& PIVO (1994); TAKANO (2010). O índice de entropia avalia a distribuição da área construída entre diferentes categorias de usos do solo dentro das zonas de análise, por exemplo, setores censitários, e pode ser calculado pela equação:

$$
E_{i}=\frac{-\sum_{j=1}^{k}\left(p_{j i}\right)\left(\ln p_{j i}\right)}{(\ln k)}
$$

Onde:

$\mathrm{E}_{\boldsymbol{i}}=$ índice de entropia no setor censitário i;

$\mathrm{p}_{\mathrm{ji}}=$ parcela da área construída ocupada pelo uso do solo j no setor $\mathrm{i}$;

$\mathrm{K}=$ número de categorias de uso do solo consideradas.

Segundo Cervero (1998) uma mistura de usos do solo entre residências, lojas, escritórios e instituições, permite aqueles que dependem do transporte público a fácil conexão entre os múltiplos destinos a pé ou no transbordo entre uma viagem e outra. O autor ainda comenta que áreas comerciais bem localizadas, podem permitir que as pessoas façam suas compras no caminho de casa ao final de um dia de trabalho, assim fazendo o encadeamento das viagens de trabalho e compras em uma única viagem. 


\subsubsection{Desenho Urbano}

O desenho urbano lida com a dimensão física espacial das cidades. Deve articular e conectar as boas práticas da Arquitetura, do Urbanismo e da Engenharia de Transportes na busca da promoção das potencialidades do ambiente construído na conversão de suas limitações em oportunidades, de forma a aproveitar e promover o contato social, a vitalidade comercial e a eficiência da cidade (VILLOTA, 2001; DEL RIO, 2004; CUTHBERT, 2005) apud RODRIGUES et al. (2013).

Sabe-se que a adoção de projetos com desenho urbano bem estruturado pode resultar em uma mudança no comportamento das pessoas quanto ao uso do automóvel, reduzindo o fluxo de veículos e incentivando as pessoas ao acesso às suas atividades por meio da caminhada. Uma boa infraestrutura fornece conexões adequadas entre origens e destinos, que inclui a distância para os pontos de ônibus, estações e terminais de transporte público dentro do ambiente construído. (MOUDON et al., 2006; CERVERO et al., 2009).

As viagens a pé no desenho urbano, o comprimento e o número dos caminhos devem ser compatíveis com as distâncias de caminhada, Rodrigues (2013), pois os pedestres possuem limitações físicas que restringem sua área de acesso, como por exemplo pessoas com mobilidade reduzida.

Neste contexto, o desenho urbano já existente dificilmente pode ser alterado e compreendê-lo pode ajudar na construção de novas localidades e em adequações de setores existentes da cidade, além de permitir investigar o grau e a qualidade de acesso dos pedestres. Por isto, a necessidade de se estudarem os indicadores que medem a influência do desenho urbano nas viagens a pé. (CERVERO et al., 2009).

Uma forma de se reduzir as viagens realizadas por automóveis, está diretamente associada à busca de alternativas que aumentem os deslocamentos feitos por modo não motorizados. Para isso é necessário que as pessoas se sintam atraídas a caminharem até seus destinos, e façam a opção por realizar o trajeto a pé ou de bicicleta, sendo ainda necessário que uma série de condições sejam satisfeitas.

Em seu trabalho na Baía de São Francisco Cervero \& Kockelman (1997) analisaram como as três dimensões, densidade, diversidade e desenho urbano, afetam as taxas 
de viagens a pé em uma área residencial, e relacionaram alguns elementos para cada uma destas dimensões conforme mostra a tabela 2.2

Tabela 2.2 - Relação das dimensões e seus elementos na estrutura urbana

\begin{tabular}{|c|c|c|}
\hline Dimensão & Elementos & Descrição \\
\hline \multirow{3}{*}{ Densidade } & Densidade populacional & Número de pessoas por hectare. \\
\hline & Densidade de emprego & Emprego por hectare. \\
\hline & Acessibilidade ao emprego & $\begin{array}{l}\text { Relação com a proximidade das atividades no } \\
\text { do uso do solo. }\end{array}$ \\
\hline \multirow{5}{*}{ Diversidade } & Índice de dissimilaridade & $\begin{array}{l}\text { Proporção de diferentes usos do solo dentro } \\
\text { de uma área. }\end{array}$ \\
\hline & Entropia & $\begin{array}{l}\text { Variação das categorias de uso do solo dentro } \\
\text { de uma área, que pode variar: } 0 \\
\text { homogênea, } 1-\text { heterogênea. }\end{array}$ \\
\hline & Mescla de categoria & $\begin{array}{l}\text { Proporção da parcela comercial/varejo com } \\
\text { mais de uma categoria de uso do solo. }\end{array}$ \\
\hline & Intensidade Comercial & Número de atividades comerciais por hectare. \\
\hline & $\begin{array}{l}\text { Proximidade Comércio } \\
\text { varejista }\end{array}$ & $\begin{array}{l}\text { Número de atividades comerciais e número de } \\
\text { residências dentro de } 1 / 4 \text { de milha }(400 \\
\text { metros). }\end{array}$ \\
\hline \multirow{3}{*}{$\begin{array}{l}\text { Desenho } \\
\text { Urbano }\end{array}$} & Rua & $\begin{array}{l}\text { Padrão predominante (malha regular, malha } \\
\text { curvilínea); } \\
\text { Proporção de cruzamentos em cruz; } \\
\text { Número de quarteirões; } \\
\text { Número de ruas sem saída. }\end{array}$ \\
\hline & Infra-estrutura & $\begin{array}{l}\text { Comprimento do quarteirão; } \\
\text { Largura de calçada; } \\
\text { Proporção de cruzamentos com controle de } \\
\text { sinalização; } \\
\text { Distância entre postes de luz; } \\
\text { Ciclovia por km. }\end{array}$ \\
\hline & Desenho local & $\begin{array}{l}\text { Proporção comércio-varejo e serviço com } \\
\text { estacionamentos } \\
\text { Estacionamento em frente e ao lado do } \\
\text { estabelecimento; } \\
\text { Parques de estacionamentos entre os } \\
\text { estabelecimentos; } \\
\text { Número de estabelecimentos que oferecem } \\
\text { serviços sem sair do carro. }\end{array}$ \\
\hline
\end{tabular}

Fonte: Cervero e Kockelman (1997). 
Tabela 2.3 - Relação das dimensões e seus elementos na estrutura urbana

\begin{tabular}{|c|c|c|}
\hline Dimensão & Elementos & Estratégia para Operacionalização/ comentários \\
\hline \multirow{3}{*}{ Densidade } & $\begin{array}{c}\text { População, unidades } \\
\text { habitacionais, ou empregados } \\
\text { por área. }\end{array}$ & $\begin{array}{l}\text { Variáveis mais facilmente acessíveis para } \\
\text { operacionalizar da estrutura urbana e, portanto, mais } \\
\text { comumente utilizadas do que qualquer outra medida. }\end{array}$ \\
\hline & & \\
\hline & Intensidade de usos do solo & $\begin{array}{l}\text { Medidas de densidade de varejo, de centros comerciais, } \\
\text { de atividades, de parques públicos, de população. }\end{array}$ \\
\hline \multirow{7}{*}{ Diversidade } & Atividades não residenciais & $\begin{array}{l}\text { Presença ou ausência de uma loja dentro de } 90 \text { metros; } \\
\text { qualquer tipo de atividades não residenciais classificadas } \\
\text { como de uso misto. }\end{array}$ \\
\hline & $\begin{array}{l}\text { Presença de restaurantes e } \\
\text { farmácias }\end{array}$ & Restaurantes ou drogaria entre 90 metros e 1600 metros. \\
\hline & $\begin{array}{l}\text { Distância da casa ao } \\
\text { supermercado, posto de } \\
\text { gasolina ou parque. }\end{array}$ & Estimativa de 160 metros. \\
\hline & Distância para o varejo. & $\begin{array}{l}\text { Percentual de domicílios a uma curta distância da zona } \\
\text { de varejo. }\end{array}$ \\
\hline & $\begin{array}{l}\text { Dados sobre o emprego no } \\
\text { varejo }\end{array}$ & $\begin{array}{l}\text { Trabalhadores de varejo dentro de } 1600 \text { metros da } \\
\text { residência; Número de estabelecimentos somados ao } \\
\text { longo de meio-quilômetro; Número de estabelecimentos } \\
\text { que são indústria; Densidade do emprego no varejo e } \\
\text { serviço por setor censitário; Distância média das viagens } \\
\text { para se comprar um dos doze itens de necessidades } \\
\text { básicas de bens e serviços (não foram definidos quais } \\
\text { itens). }\end{array}$ \\
\hline & Entropia & Mede a presença ou a ausência do uso do solo. \\
\hline & $\begin{array}{l}\text { Índice de dissimilaridade ou } \\
\text { dessemelhança }\end{array}$ & $\begin{array}{l}\text { A média de acúmulo de pontos do intervalo onde cada } \\
\text { hectare desenvolvido é avaliado com base na } \\
\text { dissimilaridade dos hectares em torno. }\end{array}$ \\
\hline \multirow{5}{*}{$\begin{array}{l}\text { Desenho } \\
\text { Urbano }\end{array}$} & Interseções em cruz & $\begin{array}{l}\text { Contados manualmente, usando fotografias aéreas e } \\
\text { mapas; Inspecionada a rede de transporte dentro } 800 \\
\text { metros de uma casa para estabelecer ruas como } \\
\text { conectadas, rua sem saída ou uma mista; Densidade de } \\
\text { interseção por zona de transporte; Número de } \\
\text { cruzamentos em cruz dentro de } 800 \text { metros das } \\
\text { residências; A média de tamanho dos quarteirões, } \\
\text { contados manualmente para cada local de estudo. }\end{array}$ \\
\hline & Rua & $\begin{array}{l}\text { Utilizadas as informações do sistema central de } \\
\text { informação geográfica. }\end{array}$ \\
\hline & Disponibilização de calçadas & $\begin{array}{l}\text { Razão entre o comprimento do sistema de calçadas e o } \\
\text { comprimento das ruas; Proporção de quarteirões com } \\
\text { calçadas; Calçadas dos dois lados, de um lado só ou em } \\
\text { nenhum dos lados da rua; A média do tempo de } \\
\text { deslocamento. }\end{array}$ \\
\hline & Volumes de tráfego veicular & $\begin{array}{l}\text { Medidos por uma única rua e aplicados a toda área de } \\
\text { estudo. }\end{array}$ \\
\hline & Dimensão do desenho & $\begin{array}{l}\text { Calçada e rua iluminadas, canteiros, comprimentos de } \\
\text { bloco, terreno plano, a acessibilidade a pé. }\end{array}$ \\
\hline
\end{tabular}

Fonte: Krizek (2003)

Em uma vasta revisão do trabalho de Cervero \& Kockelman (1997), Krizek (2003) por sua vez, propôs um índice que mede o nível de acessibilidade do bairro, através das três dimensões (densidade, diversidade e desenho urbano), no entanto, preferiu medir a influência do desenho urbano nas viagens a pé pelo tamanho dos quarteirões ou pela densidade de interseções do que por sua forma geométrica, como mostra a tabela 2.3 acima. 
Para avaliação da influência do desenho urbano sobre o comportamento e escolha do modo de viagem, pode-se utilizar o índice proposto por KRIZEK (2003). Segundo a tabela 2.3, deve-se fazer o levantamento de 5 (cinco) parâmetros: interseções em cruz, ruas, disponibilidade de calçadas, volumes de tráfego veicular e dimensão do desenho. Essas variáveis podem ser definidas através de levantamentos "in loco" e/ou com ajuda de mapas digitais da região de estudo.

Como em HANDY (1996a) e MCMILAN (2003), neste trabalho optou-se em estudar como a forma urbana influencia a escolha do modo de transporte através das características do desenho das vias e do bairro. As variáveis consideradas nesses trabalhos foram:

\section{1. Área do Setor}

Área total do Setor ou bairro, que servirá para o cálculo de outras variáveis como densidade de vias e quadras. Pode ser medida em hectare ou $\mathrm{km}^{2}$

\section{Comprimento médio das quadras}

Para o cálculo da conectividade das vias é necessário que se faça a medida do comprimento das quadras do setor. Geralmente o comprimento das quadras é medido entre os centros das intersecções das vias de cada lateral da quadra. Os padrões de comprimento das quadras variam de 0,10 a 0,20 km, mas os padrões mais aceitáveis a promover o modo a pé são comprimentos ainda menores. Quadras que possuem dimensões menores representam um aumento no número de interseções, resultando em um número maior de rotas e distâncias relativamente mais curtas de caminhadas (HANDY et al, 2002).

\section{Número total de quadras}

Referente ao número total de quadras do setor

4. Densidade de quadras

$$
\mathrm{D}_{\mathrm{q}}=\frac{\text { Número total de quadras do setor }}{\text { área do setor }}
$$


Valor referente ao número total de quadras do setor por unidade de área. Um valor mais alto da densidade de quadras representa, um número maior de quadras no setor e, portanto, uma maior variedade de caminhos aos pedestres, tornando-se mais atraentes aos usuários que optarem por andar a pé.

5. Comprimento das vias

Medida do comprimento linear das vias do bairro

6. Densidade de vias

$\mathrm{D}_{\mathrm{v}}=\frac{\text { Comprimento total das vias }(\mathrm{km})}{\text { área do setor }\left(\mathrm{km}^{2}\right)}$

É a relação entre o comprimento linear das vias por unidade de área (por exemplo, quilômetro de vias por $\mathrm{km}^{2}$ ). Um valor mais alto do índice representa mais vias e, portanto, uma conectividade mais alta.

7. Número de interseções em cruz

Número total de interseções em formato em cruz no setor

8. Número de interseções em $T$

Número total de interseções em formato $\mathrm{T}$ no setor

9. Número total de interseções

Soma do número de Interseções em cruz e T no setor

10. Densidade de Interseções

$\mathrm{D}_{\mathrm{i}=\frac{\text { Número total de interseções }}{\text { área do setor }}}$

É a medida da relação entre o número de interseções por unidade de área. Um valor mais alto desse índice indicaria um número maior de interseções e dessa forma uma conectividade mais alta

\section{Conectividade}

$\mathrm{C}_{\mathrm{PV}}=\frac{\text { número de interseções em cruz }}{\text { número total de interseções }}$ 
Uma forma de medir a conectividade é fazer uma verificação do padrão do sistema viário, ou seja, avaliar se a mesma é em forma de grelha ou não, pois um sistema viário na forma de grelha representa um maior número de intersecções em "cruz", onde teoricamente aumenta-se a conectividade entre os segmentos de vias.

Ao contrário, se um sistema viário não é em forma de grelha, significa que o mesmo possui um número maior de intersecções em "T" e cul-de-sacs em sua configuração, representando uma baixa conectividade entre os segmentos de vias. $O$ índice pode variar entre 0 e 1 e quanto mais próximo de 1 estiver, representa uma configuração do sistema viário em forma de grelha. Muitos estudos indicam esse tipo de padrão viário como sendo o mais eficiente para incentivar as viagens a pé, pois apresentam uma maior variedade de opções de rotas.

12. Largura média das calçadas

Referente a largura média das calçadas no setor

As calçadas devem possuir dimensões adequadas para o deslocamento dos pedestres e ainda a passagem dos Portadores de Necessidades Especiais (PNE) em cadeiras de rodas. Além disso, espaços para plantio de árvores e colocação de mobiliário urbanos devem ser reservados.

Segundo o HCM (2000), quando dois pedestres passam um pelo outro, para que não haja interferência na caminhada de ambos, a largura de calçada destinada a ambos deve ser de 0,8 metros de largura. Quando existirem pedestres que gostam de caminhar juntos, deve-se considerar como largura 0 espaço de 0,7 metros para cada um. Espaço lateral menor do que este só ocorre nas horas de maior movimento.

Já Gondim (2001) afirma que a calçada de uma via deve ter 1,50m de largura efetiva para que os pedestres possam transitar com segurança e conforto. A autora não avaliou fluxos de pedestres em seu estudo e as condições operacionais das vias, limitou-se somente à análise geométrica dos componentes da via, de forma individualizada. 
Existem na literatura uma quantidade diversa de métodos que visam identificar quais características do ambiente podem torná-lo o ambiente mais agradável ao pedestre, dentre eles pode ser citado o trabalho de Ferreira e Sanches (2001) que apresentaram um método que visa avaliar a qualidade das calçadas sob a ótica do usuário. A existência de calçadas e a qualidade das mesmas (nos aspectos de segurança, seguridade, conforto, conectividade e estética), além da largura adequada, podem incentivar a opção dos indivíduos em realizar suas viagens a pé.

Em Goiânia (cidade escolhida como estudo de caso nesta Tese), foi enviada à Câmara do Município em 10/06/2016 um Projeto de Lei que regulamenta as calçadas da cidade. No documento as calçadas são padronizadas quanto à inclinação, declividade, instalação de mobiliários urbanos, sequenciamento com as calçadas vizinhas e obrigatoriedade de instalação de piso tátil.

Segundo o novo Projeto de Lei, as calçadas em Goiânia devem ser organizadas em três faixas: faixa de serviço, contígua ao meio-fio; faixa livre, localizada entre a faixa de serviço e a faixa de acesso; faixa de acesso, contígua ao alinhamento frontal dos lotes ou unidades. Estas faixas padronizadas e suas medidas estão apresentadas na tabela 2.4. As medidas constantes na tabela e apresentadas no projeto de lei dizem respeito à largura da faixa; inclinação transversal máxima da calçada, com queda no sentido do lote para o meio-fio, (exceto nos rebaixos da calçada para acesso de veículos ou pedestres); largura da lixeira e indicação de permissão para ajardinamento ou floreira. 
Tabela 2.4 - Faixas de Serviço - Livre - Acesso às calçadas (Goiânia)

\begin{tabular}{|c|c|c|c|}
\hline \multicolumn{4}{|c|}{$\begin{array}{l}\text { Larguras das faixas da calçada; inclinações transversais máximas*; larguras das lixeiras; permissão para } \\
\text { ajardinamento/floreira }\end{array}$} \\
\hline \multirow{2}{*}{$\begin{array}{l}\text { Largura da calçada } \\
(\mathrm{L}) \text { em metros }(\mathrm{m})\end{array}$} & \multicolumn{3}{|c|}{ Dimensões em metros $(\mathrm{m})$, exceto inclinação transversal } \\
\hline & Faixa de serviço & Faixa livre & Faixa de acesso \\
\hline \multirow{2}{*}{$L<1,50$} & & $\begin{array}{l}\text { Largura da calçada } \\
\left({ }^{\star * \star}\right)\end{array}$ & \\
\hline & $\longrightarrow$ & Inclinação máxima de 3\% & \\
\hline \multirow{3}{*}{$1,50 \leq \mathrm{L}<2,10$} & $\begin{array}{c}\text { Largura restante da } \\
\text { calçada }\end{array}$ & $\underset{(* * *)}{\text { Largura mínima de } 1,50}$ & \\
\hline & $\begin{array}{c}\text { Inclinação máxima de } \\
3 \% \text { para calçadas novas } \\
\text { e 8,33\% para calçadas } \\
\text { antigas }{ }^{* *} \text { ) }\end{array}$ & Inclinação máxima de 3\% & \\
\hline & $\begin{array}{l}\text { Largura permitida da } \\
\quad \text { lixeira: } 0,45\end{array}$ & & \\
\hline \multirow{4}{*}{$2,10 \leq L<3,0$} & Largura de 0,60 a 1,00 & $\underset{\left({ }^{* * *}\right)}{\operatorname{Largura}}$ & $\begin{array}{l}\text { Largura restante da } \\
\text { calçada }\end{array}$ \\
\hline & $\begin{array}{c}\text { Inclinação máxima de } \\
\text { 3\% para calçadas novas } \\
\text { e 8,33\% para calçadas } \\
\text { antigas }\left({ }^{* *}\right) \\
\end{array}$ & Inclinação máxima de 3\% & $\begin{array}{c}\text { Inclinação máxima de } \\
3 \% \text { para calçadas } \\
\text { novas e } 8,33 \% \text { para } \\
\text { calçadas antigas }\left(^{* *}\right) \\
\end{array}$ \\
\hline & $\begin{array}{l}\text { Largura permitida da } \\
\text { lixeira: } 0,45 \text { a } 0,60\end{array}$ & - & 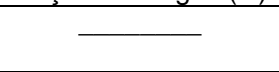 \\
\hline & $\begin{array}{c}\text { Permitida floreira } \\
\text { conforme artigo } 14 \\
\text { desta Lei }\end{array}$ & & $\begin{array}{c}\text { Permitido } \\
\text { ajardinamento } \\
\text { conforme artigo } 22 \\
\text { desta Lei. }\end{array}$ \\
\hline \multirow{4}{*}{$3,00 \leq \mathrm{L}<4,0$} & Largura de 0,70 a 1,00 & $\begin{array}{c}\text { Largura mínima de } 1,50 \\
\left({ }^{\star \star *}\right)\end{array}$ & $\begin{array}{l}\text { Largura: restante da } \\
\text { calçada }\end{array}$ \\
\hline & $\begin{array}{c}\text { Inclinação máxima de } \\
\text { 3\% para calçadas novas } \\
\text { e 8,33\% para calçadas } \\
\text { antigas }\left({ }^{* *}\right) \\
\end{array}$ & Inclinação máxima de 3\% & $\begin{array}{c}\text { Inclinação máxima de } \\
3 \% \text { para calçadas } \\
\text { novas e } 8,33 \% \text { para } \\
\text { calçadas antigas }\left(^{* *}\right) \\
\end{array}$ \\
\hline & $\begin{array}{l}\text { Largura permitida da } \\
\text { lixeira: } 0,45 \text { a } 0,85\end{array}$ & & \\
\hline & $\begin{array}{l}\text { Permitida floreira } \\
\text { conforme artigo } 14 \\
\text { desta Lei }\end{array}$ & & $\begin{array}{c}\text { Permitido } \\
\text { ajardinamento } \\
\text { conforme artigo } 22 \\
\text { desta Lei. }\end{array}$ \\
\hline \multirow{4}{*}{$L \geq 4,0$} & Largura de 0,70 a 1,00 & $\underset{\left({ }^{\star \star *}\right)}{\operatorname{Largura}}$ mínima de 2,00 & $\begin{array}{l}\text { Largura: restante da } \\
\text { calçada }\end{array}$ \\
\hline & $\begin{array}{c}\text { Inclinação máxima de } \\
3 \% \text { para calçadas novas } \\
\text { e 8,33\% para calçadas } \\
\text { antigas }\left({ }^{* *}\right) \\
\end{array}$ & Inclinação máxima de 3\% & $\begin{array}{c}\text { Inclinação máxima de } \\
3 \% \text { para calçadas } \\
\text { novas e } 8,33 \% \text { para } \\
\text { calçadas antigas }\left(^{* *}\right)\end{array}$ \\
\hline & $\begin{array}{l}\text { Largura máxima da } \\
\text { lixeira: } 0,45 \text { a } 0,85\end{array}$ & & \\
\hline & $\begin{array}{c}\text { Permitida floreira } \\
\text { conforme artigo } 14 \\
\text { desta Lei }\end{array}$ & & $\begin{array}{c}\text { Permitido } \\
\text { ajardinamento } \\
\text { conforme artigo } 22 \\
\text { desta Lei. }\end{array}$ \\
\hline
\end{tabular}

Fonte: Lei das Calçadas - Goiânia, 2014 desta Lei. 


\section{Extensão de ciclovia}

Extensão total em $\mathrm{km}$ de ciclovias no bairro. A ciclovia é um espaço reservado exclusivamente para o tráfego de bicicletas, e permite mais segurança ao ciclista. A separação do espaço é feita através de meio físico como grades, muretas, blocos de concreto, dentre outros.

\section{Extensão de Ciclofaixa}

Extensão total em km de ciclofaixa no bairro. A separação na via é feita apenas com uma faixa pintada no chão. É indicado para locais com fluxo baixo de veículos, e se trata de uma solução mais barata que a ciclovia.

\section{Extensão de ciclorota}

Extensão total em $\mathrm{km}$ de ciclorota no bairro. De uso mais recente, o termo ciclorota (ou ciclo-rota) significa um caminho, sinalizado ou não, que represente a rota recomendada para o ciclista chegar onde deseja. Representa efetivamente um trajeto, não uma faixa da via ou um trecho segregado, embora parte ou toda a rota possa passar por ciclofaixas e ciclovias. Consiste num caminho que pode ou não ser sinalizado que represente uma determinada rota de melhor acesso ao destino onde o ciclista deseja ir.

O ciclista tem os mesmos direitos que veículos, motos, ônibus e caminhões garantidos pela Constituição e pelo Código Nacional de Trânsito para trafegar pelas vias de uso comum. No entanto, existem duas exceções a isso: vias que possuem um espaço exclusivo para ciclistas e vias onde há placas sinalizando a regulamentação de que esse modal é proibido, normalmente por serem vias expressas com altos limites de velocidade.

Onde não existem estas duas exceções, ou seja, a maior parte do espaço público de todas as cidades do Brasil, a lei relata que, quando não houver ciclovia ou ciclofaixa, a via deve ser compartilhada (art. 58 do Código de Trânsito Brasileiro). Os veículos maiores devem prezar pela segurança dos menores (art. $29 \S 2^{\circ}$ ), respeitando sua presença na via e seu direito de utilizá- 
la, guardando uma distância mínima de 1,5m ao ultrapassar as bicicletas (art. 201).

\subsubsection{Disponibilidade de Transporte Coletivo}

O transporte coletivo tem importância fundamental dentro do contexto geral do transporte urbano, na medida em que é essencial para a população de baixa renda e, ao mesmo tempo, uma alternativa importante a ser utilizada como estratégia para redução das viagens por automóvel, contribuindo para a diminuição dos congestionamentos, da poluição ambiental, dos acidentes de trânsito e do consumo de combustível.

De acordo com Ferraz e Torres (2004), são doze os fatores que influenciam na qualidade do transporte público urbano: acessibilidade, frequência de atendimento, tempo de viagem, lotação, confiabilidade, segurança, características dos veículos, características dos locais de parada, sistema de informações, conectividade, comportamento dos operadores e estado das vias.

Sob a ótica do usuário, a oferta do serviço de transporte coletivo é uma das principais características desse sistema, pois a oferta determina se o transporte coletivo pode ser considerado uma opção modal para os indivíduos locomoverem-se no interior da cidade, independentemente, da qualidade do serviço. Os usuários do transporte individual, podem utilizar seus veículos a qualquer tempo que necessitar, já os usuários do transporte coletivo estão limitados à áreas e horários específicos. Dessa forma, a opção pela utilização do sistema de transporte coletivo depende, fundamentalmente, da oferta do serviço.

As condições básicas determinantes para que o transporte coletivo se torne uma opção modal pode ser traduzida em três itens Sanches et al. (2007), quais sejam:

- Cobertura do serviço: refere-se à proximidade espacial entre as origens e os destinos das viagens em relação ao ponto de embarque e desembarque, o que representa uma medida da densidade de linhas e fornece uma medida da acessibilidade ao serviço na área urbana. Uma maior cobertura do serviço implica maior acessibilidade e maior oferta de transporte coletivo; 
- Frequência: refere-se, sobretudo, ao número total de horas diárias de operação e à intensidade com que o serviço é oferecido (intervalo entre viagens). Um maior período de operação, assim como uma maior frequência, implica maior oferta de transporte coletivo; e.

- Capacidade de transporte do sistema: refere-se ao número total de passageiros que podem ser transportados com um nível de serviço adequado.

Esses três aspectos são, geralmente, utilizados para quantificar a oferta de transporte coletivo. Handy (1996a), em um estudo realizado para 6 bairros na cidade de Austin Texas, EUA, determinou três indicadores de oferta de transporte coletivo bastante simples:

- Número de linhas de ônibus que atravessam o bairro;

- Número de linhas de ônibus que margeiam o bairro;

- \% de residências no bairro que ficam a até $400 \mathrm{~m}$ (distância máxima de caminhada) de um ponto de ônibus.

Nesse trabalho os dados relativos a disponibilidade de transporte coletivo, seguirá o mesmo adotado por Handy (1996a) e também utilizado em outras pesquisas como em Cervero (1996) e Handy (1996b).

\subsection{ESTUDOS QUE RELACIONAM A FORMA URBANA E OS DESLOCAMENTOS NÃO MOTORIZADOS}

Segundo Amancio (2005), a escolha individual do modo de transporte para a realização das atividades diárias tem relação com as características dos indivíduos (sexo, idade, renda, disponibilidade de ter um automóvel, etc.), características dos modais disponíveis (custo, tempo de viagem, conforto, etc.), aspectos da viagem (comprimento, motivo, horário, etc.), e da forma urbana (densidade urbana, diversidade uso do solo, desenho de vias, etc.).

A relação entre a forma urbana e os deslocamentos a pé já foram estudados em muitos trabalhos. Muitas dessas pesquisas relatam que determinados aspectos do ambiente físico apontam o aumento de viagens não-motorizadas. Neste caso as 
viagens a pé e de bicicleta aumentam em locais que apresentam uso misto, calçadas contínuas e de largura adequada, vias bem conectadas, topografia menos acidentada, maior densidade populacional e de emprego, (CERVERO, 1996; FRANK e PIVO 1994; HANDY, 1996 a, b; AMANCIO, 2006).

Cervero (1996) executou uma pesquisa em 44 áreas metropolitanas dos EUA com população acima de um milhão de habitantes, analisando as viagens casa-trabalho. Os resultados apontaram que altas densidades e usos mistos do solo contribuem para a redução das viagens realizadas em veículos individuais, especialmente nas viagens mais curtas cujo principal motivo é o trabalho.

Handy (1996) investigou viagens realizadas pelo modo a pé a um determinado destino e viagens utilitárias para compras na região de Austin, Texas. Esta pesquisa segundo a autora buscou ir além de testar simplesmente a correlação entre forma urbana e comportamento de viagem, buscou definir um modelo mais compreensivo das escolhas realizadas pelos pedestres. A pesquisa apontou que a forma urbana influencia positivamente nas viagens não-motorizadas: onde há mix de usos (residências e empregos) há uma maior quantidade de viagens realizadas a pé; e onde não há oferta de calçadas e grande fluxo de veículos, há menor fluxo de pedestres. Segundo a autora, as análises realizadas também sugerem que certos aspectos da forma urbana têm um papel importante no encorajamento das caminhadas para um destino específico, mas têm pouca importância quando o objetivo é apenas passear. A autora conclui que a forma urbana parece ser um fator secundário para encorajar ou não as caminhadas.

Moudon et al. (1997) analisaram as cidades de Puget, Sound e Washington. A pesquisa analisou o número de deslocamentos realizados a pé em 12 bairros com características socioeconômicas semelhantes. Foi verificado que os locais onde não havia boa infraestrutura de parques e áreas verdes, além de calçadas iluminadas e arborizadas, não eram locais de boa atratividade para pedestres.

Amancio (2005) desenvolveu um estudo para a cidade de São Carlos, SP, onde foi analisado a existência da relação entre forma urbana e deslocamentos a pé. Foi examinado que nos bairros onde havia maior mistura de usos, permeabilidade das vias, oferta de transporte coletivo, variedade de moradias, parques e áreas abertas, haviam índices mais positivos de viagens a pé. Os resultados obtidos também apontaram que, tanto para viagens de $1,0 \mathrm{~km}$ quanto para viagens de $2,0 \mathrm{~km}$, as 
variáveis da forma urbana influenciam o comportamento do usuário na escolha por um modo de transporte, em especial, pelo modo a pé.

Mckibbin (2011), em seu artigo "A influência do ambiente construído sobre escolha do modo - evidência para viagens trabalho em Sydney", utilizou os cinco D's do ambiente construído - densidade, diversidade de uso do solo, qualidade dos espaços para pedestres, acessibilidade destino e distância para o trânsito - sugeridas por Ewing e Cervero (2010) como as variáveis do ambiente construído que podem reduzir o uso do automóvel em favor do transporte público, deslocamentos a pé e bicicleta. Neste artigo o autor analisou se os cinco D's do ambiente construído influenciam a escolha do modo de transporte nas viagens. Foram estudadas 1553 zonas de viagens em toda área metropolitana de Sydney, com ajuda de um GIS e análise de regressão multivariada. A pesquisa revelou que cada um dos cinco $D$ 's do ambiente construído tem diferentes níveis de influência na divisão modal de transporte para a viagemtrabalho. Todos foram considerados significativos, com exceção da qualidade dos espaços para pedestres. O autor sugere um estudo mais aprofundado deste fator, ou a utilização de um método diferente de medição, para um melhor resultado de significância. Os fatores do ambiente construído que parecem melhor influenciar a escolha do modo são densidade populacional e acessibilidade destino.

No estudo de Leslie et al. (2005) foram avaliados dois bairros com formas urbanas distintas - um com a malha tendente a regularidade (ortogonal - Norwood) e o outro irregular/orgânica (Hawthorndene), ambos em Adelaide (Austrália), mas com nível de renda e faixa etária semelhantes. Ressalta-se que Norwood apresenta caminhabilidade bastante alta com topografia sem muita variação e localização próxima ao centro da cidade; Hawthorndene, por sua vez, apresenta caminhabilidade baixa com topografia muito acidentada e longe do centro da cidade. Suas principais vias são muito movimentadas e com grande presença de mistura de usos, as menores, muitas vezes são estreitas. Para isso foi aplicado um questionário que levou em conta os atributos físicos dos ambientes de cada bairro que poderiam influenciar o deslocamento a pé, como: (a) densidade de interseções (conectividade viária), (b) densidade habitacional (relação entre o número de unidades habitacionais e área de terras com uso residencial) em cada CCD (Census Collection Districts - pequena unidade censitária) e (c) entropia (mistura de 5 usos - residencial, comercial, industrial, lazer e outros) por CCD. 
Os autores verificaram que houve diferenças estatísticas significativas na classificação das características do ambiente (em termos de densidade residencial, mistura de uso do solo - acesso e diversidade - e conectividade da via) entre os residentes dos distintos bairros, ou seja, verificou-se que os residentes percebem os atributos dos bairros de forma distinta. Foi emblemático perceber que o bairro cuja malha é mais tendente a forma orgânica foi a considerada menos caminhável e a malha cujo desenho é mais ortogonal apresentou características mais altas de caminhabilidade, pois como o trabalho expressa (e o senso comum acredita), as malhas orgânicas apresentam características mais convidativas promovidas por suas vistas mais interessantes produzidas por meio das variações topográficas embutidas no sítio urbano. No entanto, possivelmente as distintas cotas de nível presentes na malha orgânica tornam-se um aspecto negativo ao concorrer com a estrutura plana da malha reticulada.

Allan (2001) analisa o andar a pé como um modo de transporte e examina algumas das características das cidades que incentivam as caminhadas. Em sua pesquisa foi utilizado índice de permeabilidade de caminhadas, como sendo uma ferramenta de planejamento muito útil na análise de como uma área urbana facilita as caminhadas a tornarem-se uma opção de transporte local. O autor cita a importância dos fatores de densidade urbana e sistema viário como pontos críticos na escolha pelo modo a pé e propõe relacionar a permeabilidade do tecido urbano a estes fatores. Segundo o autor, as caminhadas podem ser consideradas uma opção de modo de transporte a distâncias de aproximadamente $2 \mathrm{~km}$, entre a origem e o destino da viagem em áreas onde o tecido urbano seja desobstruído, com padrão de sistema viário em forma de grelha e relativamente bem conectado. No entanto a realidade na maioria das cidades é de possuírem um tecido urbano que desestimula e restringe o acesso dos pedestres, por exemplo, com quadras de grandes extensões e vias mal conectadas.

Dill (2004) relata que os planejadores urbanos tradicionais recomendam que o desenho das vias nos bairros seja em forma de grelha, com quadras de pequena dimensão e com poucos cul-de-sacs. Estas recomendações retratam os bairros como sendo os mais amigáveis e propensos a promover os deslocamentos a pé. No entanto a autora propôs uma avaliação de uma série de medidas de conectividade de vias, com o propósito de como medir e em que níveis a conectividade é apropriada de forma a aumentar as viagens a pé. As medidas de conectividade são muito úteis em pesquisa e relacionadas a comportamento de viagem e forma urbana, onde é possível 
constatar que uma rede viária bem conectada pode representar uma redução na distância entre as viagens e um maior número de rotas ou caminhos disponíveis ao usuário. Outro fator importante observado é a influência da conectividade viária nas políticas públicas que são capazes de estabelecer novos padrões de desenvolvimento urbano. Foram aplicadas quatro das medidas de conectividades de vias avaliadas na região metropolitana de Portland, são elas: densidade de interseções, densidades de vias, porcentagem de interseções conectadas, relação de segmento de via por interseção. A autora pôde concluir que apesar de correlatas as medidas não indicaram um mesmo nível de conectividade na área estudada, mas em geral, as áreas mais conectadas são no centro da cidade de Portland e no lado leste (leste do Rio de Willamette que corre norte-sul pelo meio da região). Estas são áreas que se desenvolveram em grande parte antes de 1950 e são constituídas por um padrão de via em forma de grelha.

Rodriguez e Joo (2004) examinaram, através de modelos multinomiais, a relação entre a escolha do modo de viagem e as características do ambiente físico, como topografia, densidade residencial, disponibilidade de calçadas e presença de rotas para ciclismo e caminhadas. Os dados necessários à realização desta pesquisa foram os de estudantes da Universidade da Carolina do Norte de modo a ilustrar a relação entre a escolha do modo e os atributos do meio físico cujo objetivo era de avaliar as características modais típicas de viagem, como tempo de viagem, tempo de acesso e custo. Portanto, de acordo com os resultados encontrados, a topografia e a disponibilidade de calçada são significativamente associadas à atratividade dos modos não motorizados.

Cervero e Kockelman (1997) estudaram 50 bairros da Baia de São Francisco, e analisaram como a densidade, diversidade, e desenho urbano influenciam as escolhas das viagens e descobriram que a intensidade de utilização (como por exemplo densidade de lojas de varejo, centro de atividades diversas, densidade populacional, boa acessibilidade, número de parque) foi associado com níveis mais altos de viagens não-motorizados. Cervero (2002) descobriu que variáveis do ambiente construído, tais como população, densidade de emprego e diversidade de uso do solo - todos medidos no nível TAZ, melhoram os modelos de modo de escolha e que o fator mais significativo do ambiente construído é a razão entre calçadas/milhas de estradas.

Em seu trabalho sobre a influência da forma urbana no comportamento de viagem das pessoas em Uberlândia - MG, DEUS (2008), estudou a relação existentes entre a 
forma urbana de seis zonas de tráfego da cidade, e o seu sistema de transporte urbano, buscando definir como as características físicas de uma determinada região influenciam no comportamento de viagem das pessoas. O autor estudou a população geral da cidade, e não examinou especificamente o comportamento das viagens das crianças. Os dados levantados pelo autor, constam no Plano Diretor da cidade, e o mesmo, não realizou pesquisa de campo para levantamento das variáveis. As variáveis da forma urbana levantadas e definidas na revisão bibliográfica foram: densidade urbana; diversidade de usos do solo; qualidade dos espaços que favoreçam o transporte não motorizado; disponibilidade de transporte coletivo; desenho e conectividade das vias; e topografia da cidade. O autor usou um modelo do tipo logit multinomial para determinar o grau de influência da forma urbana sobre 0 comportamento de viagem. Inicialmente foram calibrados modelos utilizando apenas as variáveis sócio-econômicas dos viajantes e depois foram incluídas as variáveis que caracterizam a forma urbana. Os resultados obtidos indicaram que as variáveis da forma urbana não têm influência significativa no processo de escolha modal nas viagens realizadas dentro na cidade, não sendo determinantes para definição do modo de transporte a ser usado. As variáveis sócio-econômicas, em especial a renda, e o comprimento das viagens se mostraram como os fatores mais determinantes para a escolha do modo de transporte.

\subsection{TÓPICOS CONCLUSIVOS}

Nesse capítulo foi descrita a bibliografia referente as questões entre a relação da forma urbana e comportamento na escolha do modo de transporte. Foi apresentado também alguns conceitos de forma urbana, os quais apresentaram algumas variações, porém com o mesmo fundamento básico, ou seja, a forma urbana diz respeito a um conjunto de características físicas de um determinado ambiente, bem como a distribuição de atividades ao longo do espaço.

De acordo com o que foi investigado, a maior parte dos estudos indicam que existe influência da forma urbana sobre o comportamento de viagem, e que determinados aspectos da forma urbana podem contribuir para o aumento de viagens realizadas a pé e conseqüentemente a redução das viagens realizadas por automóveis. Nestes casos as viagens a pé e de bicicleta aumentam quando em locais que apresentam uso misto, calçadas contínuas e de largura adequada, vias bem conectadas, topografia menos acidentada, maior densidade populacional e de emprego. 
Apesar de muitos estudos apontarem uma relação entre forma urbana e comportamento de viagem, outras pesquisas sobre o assunto indicam que a forma urbana não tem uma influência direta nas escolhas pessoais e apontam as características socio-econômicas como variáveis mais determinantes na escolha do modo de viagem. Segundo Deus (2008), as controvérsias podem surgir devido às próprias diferenças existentes entre cidades européias e cidades norte-americanas, que são as mais utilizadas como objetos de estudo, e também entre as cidades referidas e as cidades brasileiras. Dessa forma, fica evidente que os pesquisadores dos mais diversos países ainda precisam se aprofundar no assunto para se tentar chegar a resultados mais específicos que expliquem melhor a relação entre forma urbana e comportamento de viagem.

Com relação às viagens realizadas pelas crianças e sua relação com a forma urbana os estudos são ainda mais escassos. A maior parte destes estudos investigam especificamente as viagens dos adultos. Boarnet et al. (2005) e Stauton et al. (2003) demonstraram que mudanças no ambiente construído, tais como melhoria em calçadas e cruzamentos de ruas, podem incentivar os alunos a utilizarem o modo a pé até a escola. Essa escassez de trabalhos abordando crianças serviu de motivação para a definição do tema da presente pesquisa. 
Viagens Escolares das Crianças 


\subsection{VIAGENS ESCOLARES DAS CRIANÇAS}

\subsection{COMPORTAMENTO DAS VIAGENS DAS CRIANÇAS ATÉ A ESCOLA}

Como citado no capítulo anterior, o foco principal das pesquisas que relacionam comportamento de viagens e forma urbana concetraram-se nos adultos. No entanto, segundo Kitamura (1998), a presença de crianças em uma família, altera substanciamente o comportamento e os padrões de viagem de um domicilio. Dessa forma, o entendimento das viagens das crianças, se faz necessário para uma melhor compreensão das viagens dos adultos, haja visto, que os pais, especialmente as mães, estruturam suas viagens em torno das necessidades de seus filhos e coordenam seus próprios horários de trabalho, em função dos compromissos escolares de seus filhos.

Segundo dados ANTP (2011) as pessoas percorrem 422 bilhões de quilômetros por ano (cerca de 1,40 bilhões por dia), usando várias formas de deslocamento. A maior parte das distâncias é percorrida nos veículos de transporte público $(57,1 \%)$, seguido pelos automóveis, nos quais as pessoas percorrem $31,4 \%$ das distâncias. Este dado mostra que a população urbana brasileira (municípios com mais de 60 mil habitantes) já é dependente de meios motorizados de transporte para realizar a maioria das suas atividades.

Ainda, no relatório ANTP (2011), existem dados agregados do número de deslocamentos realizados nos principais municipios brasileiros, número de veículos por municipio e o indice de mobilidade por municipio com mais de 60 mil habitantes. Porém, não existem dados ou estatísticas dos deslocamentos das crianças e por consequencia nenhum dado sobre a influência das viagens das crianças sobre a dos adultos.

As crianças pertencem a um grupo de usuários frágeis e dependentes, pois necessitam de um adulto para realizar seus deslocamentos. Como os adultos, as crianças precisam de transporte para atividades como educação, lazer e saúde. No entanto, diferentemente da maioria dos adultos, as crianças são, em grande parte dependente dos outros para fornecer esse transporte.

Segundo o Transporte Survey (NPTS), $69 \%$ de todas as viagens feitas por crianças de 5-15 anos em 2005 nos EUA foram realizadas em um veículo individual. As viagens 
escolares, constituiram cerca de $26 \%$ das viagens feitas por crianças entre 5-9 anos de idade; apenas $10,5 \%$ dessas crianças utilizaram o modo a pé para o deslocamento, $52,8 \%$ utilizaram veículo privado; $30,2 \%$ ônibus escolar e $6,5 \%$ outros modos.

Nas várias pesquisas sobre o assunto, os pais citam longas distâncias e tráfego intenso como os principais obstáculos à sua criança se deslocar a pé ou de bicicleta até a escola, (DELLINGER E SATAUNTON, 2002; MCMILLAN, 2003; MCDONALD, 2005). Os pais ainda relatam que as ruas mais próximas da escola são também alguns dos locais mais perigosos para que as crianças se desloquem a pé ou de bicicleta, devido ao elevado volume de tráfego e ainda a falta de educação dos condutores de veículos nas proximidades dessas escolas.

Segundo Handy (1996a), a acessibilidade de infra-estrutura para pedestres (com foco em presença, qualidade, viagens, distâncias e opções de rota) estão associados com o comportamento de caminhar, em uma pesquisa sobre o comportamento de um adulto e forma urbana. No caso das viagens das crianças à escola, é possível que a enorme distância de casa à escola poderia ser uma das maiores barreiras para o deslocamento a pé ou de bicicleta (DIGUIUSEPI et al., 1998).

A questão dos impactos da forma urbana nas viagens de uma criança até a escola é complexa. As pesquisas existentes e os modelos comportamentais não conseguem responder à questão por causa do foco limitado sobre crianças e transporte não motorizado. É necessario uma estrutura conceitual que englobe: 1) a questão comportamental das crianças individualmente, ao invés de agrupá-las ao comportamento de viagens motorizadas dos adultos (HILMAN et al., 1973); e 2) uma abordagem que contemple a complexa estrutura das relações que existem na decisão sobre a viagem de uma criança para a escola.

Essa temática do deslocamento ativo de crianças e adolescentes até a escola vem sendo debatida e investigada em nível mundial, na última década. O uso da bicicleta e o deslocamento a pé nas viagens escolares surge como uma questão ligada aos transportes, no entanto, tem influência direta também com a saúde. Nas questões relacionadas aos transportes, surge como uma forma de melhoria nos congestionamentos e os problemas relacionados a ele, como emissão de gases poluentes. Nas questões de saúde colaboram no cumprimento das recomendações da Word Health Organization - WHO (2010) do nível diário (60 min) de atividade física, Tudor-Locke et al. (2001), bem como, na prevenção da obesidade infantil, Lu et al., 
(2015) e na promoção de comportamentos ativos e saudáveis na rotina de vida das crianças e adolescentes (PEREIRA et al., 2014; PABAYO et al, 2011)

Segundo Matos et al. (2014), em uma pesquisa sobre transporte para escola com adolescentes, os dados do Inquérito Nacional de Saúde (1998-1999) apontam que, os adolescentes com mais de 15 anos de idade, passam $73 \%$ do tempo livre assistindo televisão, ou em outra atividade sedentária, como utilizando o computador. Aliado ao aumento das viagens realizadas por automóveis, e ao estilo de vida sedentário, ocorreu um aumento alarmante na obesidade infantil e, a nível mundial, estima-se que um terço dos jovens não seja suficientemente ativo para contribuir para o seu bemestar presente e futuro.

Esta pesquisa ampara-se na descrição do autor e procura utilizar o modelo desenvolvido por HANDY (1996 a) e ampliado em McMILLAN (2003). No entanto, como citado anteriormente, os dados de transportes foram inseridos no modelo desta tese, em uma reformulação do modelo proposto por McMillan. Dessa forma a teoria apresentada a seguir, segue o mesmo raciocinio de McMillan, pois é a base para formulação do modelo final.

\subsection{QUESTÃO MULTIDISPLINAR}

Como já relatado anteriormente o comportamento de viagem das crianças ainda é um tema pouco compreendido pelos profissionais tanto do planejamento de transportes, quanto dos relacionados com a saúde física. No entanto, a importância do assunto se estende para além das fronteiras disciplinares tradicionais de planejamento. A viagem da criança para a escola, é tanto complexa quanto importante, e analisar o tema de uma forma multidisciplinar ajuda a definir seu significado e entender de que maneira a forma urbana influencia a escolha do modo de viagem da criança até a escola.

\subsubsection{Transporte}

Em pesquisas que estudam o deslocamento das crianças e modo de escolha do veículo, os pais relatam que os principais empecilhos a sua criança se deslocar a pé ou de bicicleta até a escola estão a distância e o intenso tráfego de veículos.

O cuidado e proteção dos pais em relação ao deslocamento ativo do seu filho até a escola, afetam o tráfego nas proximidades das escolas e impactuam de maneira 
importante a rotina dos pais, na forma de incrementos de viagens e limitação dos horários de trabalho e outras atividades, como compras ou lazer. Apesar, de uma mudança no comportamento em relação aos cuidados com os filhos nas famílias (pais e mães são responsáveis pelas atividades dos filhos, inclusive a escola), as mães tendem a fazer um número maior de viagens até a escola para deixar e buscar a criança, em relação aos pais. (ROSENBLOOM, 1987).

Segundo Bradshaw (2001) os hábitos formados mais cedo são difíceis de romper. Por isso, crianças que fazem a maioria de suas viagens de carro, quando crescem tendem a continuar com esse comportamento na idade adulta e podem ser mais relutantes em viajar por modos alternativos de transporte. Apesar de haver uma vasta literatura sobre o assunto, porém envolvendo os adultos, ainda existem poucas pesquisas envolvendo as crianças e que apoiem tal hipótese.

\subsubsection{Saúde}

- Atropelamentos

A morte de crianças no trânsito quer por atropelamento ou bicicleta causa um grande impacto na sociedade. Segundo dados do Departamento de Informática do Sistema Único de Saúde - DATASUS (2014) a cada morte de uma criança de 0 a 9 anos, outras quatro ficam com sequelas permanentes que irão gerar, provavelmente, consequências emocionais, sociais e financeiras a essa família e à sociedade.

Os acidentes de trânsito são a primeira maior causa de mortes entre crianças no Brasil entre 5-9 anos de idade. Ainda, segundo dados do DATASUS (2014), entre 0-9 anos aconteceram 3.142 mortes nesta faixa etária, e mais de 75 mil hospitalizações de meninos e meninas, o que caracteriza o acidente como um grave problema de saúde pública. Os acidentes de trânsito, que incluem atropelamentos, passageiros de veículos, motos e bicicletas, representaram 33\% destas mortes, seguidos de afogamento (23\%), sufocação (23\%) queimaduras $(7 \%)$, quedas $(6 \%)$ e outros $(6 \%)$.

Segundo Vasconcellos (2000) pode-se citar como fatores gerais causadores do alto número de acidentes viários, o acelerado processo de urbanização brasileiro, o crescimento populacional expressivo, o padrão de ocupação desordenado do solo e o aumento extremo no número de veículos no trânsito e que segundo Cardoso (1999), compreender os eventos e fatores que influenciam nas ocorrências de acidentes de tráfego é de fundamental importância para adoção de medidas que visem à redução desses acidentes no trânsito. 
Diminuir a velocidade nas ruas para reduzir a gravidade de acidentes de trânsito é uma prática adotada em muitos países e que está começando a ganhar espaço nas cidades brasileiras. Em julho de 2015 a prefeitura da cidade de São Paulo baixou, a velocidade máxima nas marginais Tietê e Pinheiros. Nas pistas que permitiam 90 $\mathrm{km} / \mathrm{h}$, agora as placas indicam $70 \mathrm{~km} / \mathrm{h}$, onde era $70 \mathrm{~km} / \mathrm{h}$ passou para $50 \mathrm{~km} / \mathrm{h}$. Um ano após a redução da velocidade nessas marginais, dados da Companhia de Engenharia de Tráfego (CET) em 2015, mostraram que a quantidade de acidentes com vítimas e a lentidão nas vias apresentaram queda de 38,5\% e 8,7\%, respectivamente.

Estima-se que a probabilidade de um pedestre vir a óbito quando atingido por um veículo a $32 \mathrm{~km} / \mathrm{h}$ é de $5 \%$, esse percentual sofre um incremento para $40 \% \mathrm{com}$ veículos viajando a $48 \mathrm{~km} / \mathrm{h}, 80 \%$ a $64 \mathrm{~km} / \mathrm{h}$, e quase $100 \%$ para veículos trafegando com velocidades acima de $80 \mathrm{~km} / \mathrm{h}$, Pasanen (1993). A redução da velocidade para os veículos se deslocando em zonas escolares, seria uma alternativa que a administração pública poderia utilizar como instrumento na redução dos acidentes com crianças que utilizam o modo a pé ou bicicleta para irem até a escola.

\section{- A inatividade física / Obesidade}

Como citado anteriormente, o deslocamento diário das pessoas pode contribuir para um estilo de vida mais ativo. Ir a pé ou bicicleta até a escola ou trabalho têm demonstrado associações positivas na saúde das pessoas em geral, (OLGIVIE et al., 2004). No entanto é crescente, principalmente em áreas urbanas o número de pessoas que se deslocam de forma passiva.

Segundo (NATIONWIDE PERSONAL TRANSPORTATION SURVEY - NPTS, 2007) apud (SILVA, 2007) nos Estados Unidos, entre o período de 1969 a 1995, o aumento do número de veículos particulares foi seis vezes maior do que o da população americana. Entre as metas traçadas pelo Department of Health and Human Services no relatório para Health People 2010 destaca-se o aumento de 31 para 50\% no uso do deslocamento ativo pelos estudantes que moram a menos de 1,6 km da escola.

A Organização Mundial de Saúde (OMS) aponta a obesidade como um dos maiores problemas de saúde pública no mundo. A projeção é que em 2025 o número de crianças com sobrepeso no mundo pode chegar a 75 milhões. No Brasil, o aumento do número de obesos na idade infantil, também é crescente e segundo dados do IBGE (2009), 15\% das crianças brasileiras estão com sobrepeso. O relatório ainda indica 
que em 1975 o percentual de crianças obesas no Brasil entre 5-9 anos era de 4,7\%. Esse percentual aumentou para 28,4 \% em 2009.

Pesquisas realizadas entre a comunidade de saúde relatam uma relação causal entre sedentarismo e saúde corporal. O sedentarismo está associado ao risco aumentado de doenças cardiovasculares e outras doenças crônicas e, devido a recente preocupação com o aumento na prevalência de obesidade em crianças e adolescentes, a promoção da atividade física nestas populações tornou-se uma prioridade para a saúde pública.

No Brasil ainda são escassos os estudos que abordem deslocamentos ativos das crianças até a escola, e quais são os ganhos para saúde utilizando esse modo de transporte. Algumas evidências relatam que escolares que se deslocavam ativamente para a escola, demonstraram excesso de peso e de gordura corporal menor em relação aos escolares conduzidos de carro, Silva e Lopes (2008), assim como o estudo de Souza et al. (2010), que mostrou uma relação significativa entre inatividade física e sobrepeso.

Pode-se observar que as questões relacionadas a forma urbana e a viagem das crianças para a escola é complexa. Além de ser necessário o tratamento de uma forma multidisciplinar as pesquisas existentes e os modelos de comportamento de viagem e atividade física ainda são limitadas as viagens dos adultos. Dessa forma se faz necessário um modelo que aborde: o comportamento de viagem exclusivamente para as crianças e que consiga detalhar as relações que existem na decisão da viagem da criança até a escola.

\subsection{FATORES QUE INFLUENCIAM A VIAGEM DAS CRIANÇAS ATÉ A ESCOLA}

A figura 3.1 mostra a complexa relação entre a forma urbana e a viagem das crianças até a escola. O modelo foi proposto por McMillan (2003) e se mostrou mais adequado, principalmente por:

1 - Identificar o decisor sobre o comportamento das viagens das crianças;

2 - Identificar os fatores que podem influenciar na tomada de decisão da viagem da criança até a escola;

3 - Descrever como esses fatores influenciam a relação entre a forma urbana e as viagens escolares. 
O modelo supõe que até uma certa idade da vida de uma criança, a decisão final sobre a escolha do modo de veículo até a escola é do pai e não dessa criança. Seguindo essa lógica, a tomada de decisão dos pais pode ser considerada como uma variável intermediária ou mediadora do comportamento de viagem da criança. No item 3.3.1 os fatores mediadores estão conceituados.

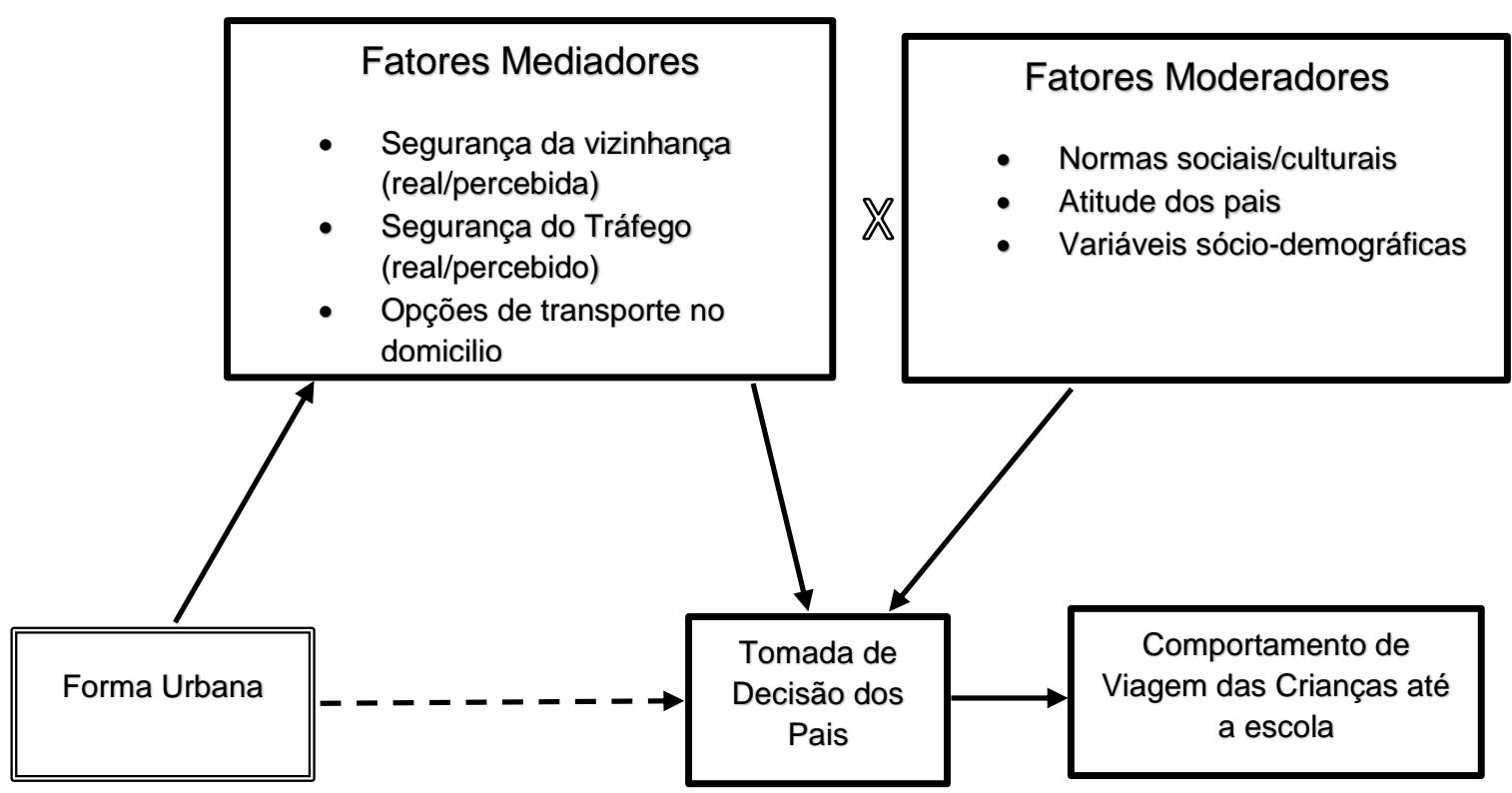

Figura 3.1 - Diagrama do modelo conceitual do comportamento de viagem de uma criança até a escola. Fonte: McMILLAN, 2003

Nesse modelo proposto por McMillan (2003) as setas sólidas indicam a hipótese de relações diretas; setas pontilhadas destaca a hipótese de relações indiretas; $X$ indica a interação entre fatores mediadores e fatores moderadores. O modelo pressupõe ainda que até uma certa idade, a decisão final sobre o modo de viagem de uma criança até a escola é dos pais ou cuidadores. Dessa forma essa decisão não está limitada aos horários ou restrições das crianças, mas é influenciada sobremaneira pela determinação dos mesmos. Assim a tomada de decisão dos pais pode ser vista como uma variável intermediária entre a forma urbana e o comportamento de viagem da criança.

A tomada de decisão dos pais em si pode ser influenciada por outras variáveis intervenientes, entretanto elementos da forma urbana, tais como comprimento de quadra ou iluminação pública pode influenciar fatores psicossociais (percepções de segurança do bairro e/ou de trânsito), pois uma rua mal iluminada, sugere aos pais risco de assalto ou até mesmo atropelamento devido à baixa luminosidade. Que por sua vez pode influenciar a tomada de decisão dos pais sobre como uma criança 
poderá viajar até a escola (criando "uma série de mediadores em cascata" que intervêm e são causalmente relacionados em sequência entre a forma urbana e as viagens de uma criança até a escola). São esses fatores que trazem a natureza e a forma da relação de como a forma urbana impacta a viagem de uma criança até a escola.

O modelo acima proposto por McMillan (2003) tem a sua estrutura semelhante à de Handy (1996b), quando relaciona a motivação para caminhar e a forma urbana, exceto a ordem causal, que é inversa. O modelo de Handy sugere que, dada a motivação para caminhar, a forma urbana é um fator externo que pode permitir ou impedir a caminhada real. O modelo de Macmillan sugere, por sua vez, que é a tomada de decisão dos pais em relação as características do ambiente físico e sua atuação sobre os diferentes modos de transporte, que ditam como a criança se deslocará até a escola.

Ainda sobre o modelo de McMillan, o mesmo sugere que não são apenas algumas intervenções na forma urbana que vão aumentar as viagens das crianças a pé/bicicleta/ônibus até a escola. Por exemplo, uma calçada pode não ser o motivo principal para as baixas taxas de deslocamento a pé; há de se abordar preocupações subjacentes que os pais têm sobre as viagens de uma criança até a escola - como a segurança do tráfego. Segundo a autora há de se realizar melhorias em alguns elementos dos fatores mediadores identificados ao longo do caminho de decisão.

Outros fatores que não são da forma urbana, mas que também influenciam a tomada de decisão dos pais, são as variáveis moderadoras (renda familiar, idade das crianças, normas culturais, etc), que aparentemente não tem relação alguma com a forma urbana, no entanto aparecem no modelo de McMILLAN como agentes influenciadoras na decisão final. Como por exemplo, a tomada de decisão dos pais quanto ao modo de viagem até a escola pode variar com o sexo da criança, e o mesmo não se sentir seguro a incentivar o filho a andar até a escola por se tratar do sexo feminino.

\subsection{1 - Fatores Mediadores}

Uma dada variável é dita mediadora quando representa a relação entre a variável de previsão e o critério (BARON e KENNY, 1986, p.1176). Neste caso, a forma urbana (por exemplo, calçadas) é a variável de previsão e o comportamento de viagem das crianças é a variável critério. O conceito de mediação implica suposição de relacionamentos entre as variáveis envolvidas, (ABBAD E TORRES, 2002). Assim a 
percepção de segurança do tráfego pode influenciar os pais a não incentivar seus filhos a caminhada por medo de atropelamentos. Os fatores mediadores relacionados na pesquisa realizada com os pais dos alunos do ensino fundamental de Goiânia foram: Segurança do bairro, Segurança do tráfego e Opções de transporte no domicílio.

\section{- Segurança do bairro}

Alguns elementos do desenho urbano, por sua aparência e falta de segurança, podem causar nos pais sensação de risco às crianças se deslocarem a pé/bicicleta/ônibus. Segundo McMillan (2003) duas pesquisas diferentes DiGuiseppi et al. (1998) e Eichelberger et al. (1990), realizadas com pais de crianças entre 2 a 9 anos, revelou que os mesmos estavam mais preocupados com sequestros ou abordagens de estranhos aos filhos do que um dano físico causado por acidente; esse medo de sequestro foi um forte influenciador das viagens de carro até a escola

Da mesma forma, o estado de conservação dos equipamentos urbanos pode causar sensação de risco ou perigo aos pais, e pode levar os mesmos a restringir determinadas viagens dos filhos. Ruas degradadas, com pouca iluminação e baixa vigilância, promovem sensação de medo e perigo aos moradores de um determinado bairro.

Segundo McDonald et al. (2011) as atitudes dos pais também influenciam a forma do deslocamento das crianças para cumprir suas atividades. Quando os pais constatam menos barreiras ou mais benefícios potenciais como segurança e acessibilidade, as suas crianças são mais propensos a se deslocarem a pé ou de bicicleta até a escola.

\section{- Segurança do Tráfego}

Da mesma forma, o tráfego pode influenciar o modo de viagem das crianças. Ruas com elevados volumes de tráfego podem constituir em maior risco de lesões e morte por atropelamentos, por exemplo. Se o volume de tráfego é alto nas imediações das escolas e bairros residenciais, os pais podem se sentir desencorajados a deixar seus filhos a andarem a pé ou de bicicleta para realizar qualquer tipo de viagem, por lazer ou por atividades escolares. 
O sentimento de medo que os pais possuem do tráfego de veículos é uma medida difícil de ser mensurada, e nem sempre serve de previsão e esclarece as viagens feitas de carro até a escola. No entanto, DIGuiseppi et al. (1998) afirma que percepções de tráfego pesado tem efeitos positivos sobre o comportamento de viagem dos adultos, significando até um impedimento sobre os deslocamentos a pé. A influência da segurança de tráfego na tomada de decisão dos pais pode variar segundo o controle que os mesmos exercem sobre o comportamento da criança, e para alguns destes, a presença de outros adultos caminhando até a escola, pode influenciar sua própria percepção sobre o tráfego, e um caminho quando percorrido sozinho é perigoso, mas quando outros o fazem, já não lhe parece tão arriscado.

- Opções de transporte no domicílio

A posse de automóvel pelas famílias, pode afetar a decisão sobre a viagem de uma criança, e segundo Kitamura et al. (1997) está positivamente correlacionada com viagens de automóvel, e quanto maior o número de veículos no domicilio menor será a probabilidade dos deslocamentos a pé/bicicleta/ônibus.

Ainda em Kitamura et al. (1997) distâncias menores entre pontos comerciais, serviços de lazer, entre outros, tem uma correlação positiva com o número de viagens a pé e não motorizadas. A presença e a continuidade das calçadas também facilita a atividade de caminhada. Segundo Mcmillan (2003) apud Diguiseppi et al. (1998) o acesso afeta as decisões dos pais sobre a viagem de seus filhos para a escola e a distância física entre a casa e a escola limita as opções de transportes disponíveis.

Ainda segundo McMillan (2003) a presença de ciclovias, passagens para pedestres e presença de lombadas próximos as escolas influencia positivamente a viagem das crianças para a escola a pé ou de bicicleta. As crianças que vivem em áreas de alta densidade (ou áreas de maior acessibilidade aos centros de atividades) são menos propensos a ir de ônibus para a escola e mais propício a usar os modos não motorizados, (McDONALD, 2005).

\subsection{2 - Fatores Moderadores}

Um fator moderador é uma variável qualitativa ou quantitativa que afeta a direção e/ou a força da relação entre uma variável independente ou preditor e uma variável 
dependente ou critério, (BARON E KENN, 1986). Uma variável moderadora relacionase com determinados fatores circunstanciais que podem aparecer no meio de uma investigação, passando por vezes desapercebidos, no entanto, causam desvios, moderando ou alterando os resultados. A variável moderadora apresenta-se geralmente, ligada a variável independente, reforçando ou inibindo a ação desta.

Os fatores moderadores relacionados nesta pesquisa realizada com os pais dos alunos do ensino fundamental de Goiânia foram: Atitude dos Pais e Variáveis Sócio demográfica.

- Atitude dos pais

Em uma pesquisa em que relacionou uso do solo, transporte e atitude, Kitamura et al. (1997) verificaram que as atitudes e opiniões de um indivíduo (pró-meio-ambiente, prótrânsito, pró-mobilidade automotiva), foi um forte preditor no comportamento de viagens, talvez mais forte que as questões do uso e ocupação do solo. Apesar dessa pesquisa não contemplar as viagens das crianças diretamente, os resultados sugerem que a atitude de um pai pode influenciar não só a sua própria decisão de viagem, mas também a de seu filho. Em contrapartida, as atitudes das crianças podem influenciar também as decisões dos pais, sobre o modo de viagem até a escola. Se uma criança não quer ir a pé até a escola, por um motivo qualquer, os pais podem ser persuadidos a conduzir esse filho por outros modos.

- Características sócio demográficas

Outras variáveis que influenciam o modo como os pais escolhem o modo de transporte até a escola para seus filhos é a idade, sexo e número de filhos no domicilio. Famílias com muitos filhos ou crianças menores em pré-escola, podem influenciar viagens de automóveis para a escola, atividade recreativa e cuidados médicos.

Estudos realizados por Liu et al. (2012) sobre o comportamento dos pais na condução de seus filhos até a escola relatam que as mães tem uma tendência maior do que os pais de acompanhar suas crianças até a escola. Uma explicação para tal fenômeno baseia-se no fato de que este é um papel tradicional de gênero das mulheres na divisão do trabalho doméstico.

Segundo Yalargada e Srinivasan (2008) várias características do agregado familiar também afetam o modo de viagem das crianças até a escola. Em geral, estudantes de 
famílias de baixa renda e cujas famílias não possuam um carro, são mais propensos a se deslocarem a pé ou de bicicleta para a escola, enquanto estudantes de famílias de alta renda e cujas famílias possuem mais carros são mais propensos de serem conduzidos de veículo individual até a escola. À medida que aumenta a idade das crianças, suas atividades diárias tornam-se mais complexas, resultando em uma maior restrição sobre (muitas vezes) as viagens dos pais que trabalham.

De acordo com os tópicos mencionados acima pôde-se perceber que as análises sobre comportamento de viagem é complexa e dependem da inserção de variáveis que segundo Acker (2008) devem referenciar: (1) características espaciais do ambiente urbano; (2) características socioeconômicas; (3) características sociopsicológicas (atitudes) dos indivíduos e domicilios. Nessa tese serão estudadas variáveis que devem fazer referência aos três tópicos.

\section{4 - ESTUDOS QUE RELACIONAM DESLOCAMENTO DAS CRIANÇAS E FORMA URBANA}

Os resultados do trabalho "Forma Urbana e deslocamentos a pé: Modelando e Testando Decisões dos Pais sobre a Viagem das Crianças" desenvolvido por McMillan (2003) revelaram a hipótese que a forma urbana é importante, no entanto não é o único fator que influencia na escolha do modo de viagem até a escola. Outros fatores, tais como; a percepção de segurança na vizinhança e no trânsito; a opção de transporte familiar e as normas sócioculturais, se mostraram importantes influenciadores na tomada de decisão dos pais. O modelo utilizado foi um Logit binomial, cujo objetivo foi conhecer a probabilidade que a forma urbana e também outros fatores podem afetar o deslocamento das crianças até a escola.

O modelo afirma que o deslocamento das crianças é afetado por diversos fatores incluindo a forma urbana, no entanto, as probabilidade indicaram que fatores moderadores e mediadores (segurança da vizinhança, segurança do tráfego, opções de transporte no domicilio, normas sociais/ culturais, atitude dos pais, variáveis sócioeconômicas) são maiores que o da forma urbana.

Outro trabalho que estudou como a forma urbana influencia as viagens das crianças até a escola foi o de McDonald (2005). Em seu modelo a autora buscou responder três hipóteses: 1) Quais são os padrões atuais de viagens das crianças; 2) Quais os fatores que têm a maior influência sobre a escolha do modo de viagem infantil até a escola, principalmente o modo a pé; e 3) Como o planejamento do uso do solo pode 
afetar a caminhada até a escola. O objetivo da pesquisa foi identificar os fatores que tem uma forte relação sobre a escolha do modo, incluindo os efeitos do uso do solo, sobre a decisão de caminhar até a escola. Foi utilizado um modelo logit multinomial para testar a probabilidade das crianças viajarem a pé, ônibus escolar e carro individual, sendo influenciadas por variáveis como tempo de viagem, características do individuo (idade, sexo, etc), renda, e variáveis ligadas ao uso do solo como densidade e diversidade de usos.

A análise do modelo identificou a distribuição espacial dos estudantes e escolas como a principal razão para as baixas taxas de caminhada. A autora relata que em 1969 nos EUA, $45 \%$ dos alunos da escola viviam a menos de uma milha da escola e atualmente menos de $24 \%$ moram a esta distância e afirma que o fato de a maioria das crianças não viverem à uma distância satisfatória de suas escolas é o principal fator para o aumento do uso de automóveis nas viagens escolares.

Outro interesse substancial dos pesquisadores sobre as viagens das crianças está no padrão e engajamento das atividades extra-curriculares. Vários estudos examinaram as taxas de participação das crianças em atividades pós-escola. Por exemplo, Huebnere Mancini (2003) analisou os padrões de 509 estudantes entre 9 e 12 anos de idade e descobriu que $26 \%$ dos observados não participam de quaisquer atividades extra-curriculares depois da escola e $75 \%$ gastam seus tempo em clubes nãoescolares. Já Hofferth et al. (1991) centrou-se em padrões de atividades de crianças menores, entre 5 e 12 anos e as taxas de participação encontradas foi de apenas 12\% dos 5 aos 9 anos de idade e 23\% dos 10 aos 12 anos de idade participantes em atividades após a escola.

Posner e Vandell (1997) examinaram os padrões de atividade de 194 crianças brancas e negras entre 3 e 5 anos e observou que $20 \%$ do tempo de pós-escola, foi gasto assistindo televisão, e apenas $4 \%$ foi gasto em esportes. Shann (2001) pesquisou 1.583 crianças no centro da cidade e descobriu que mais de $75 \%$ destas não participam em qualquer programa pós-escola. Por outro lado, cerca de $90 \%$ assistia televisão em um modo passivo. A participação em atividades extra-curriculares estruturados é substancialmente maior na Suécia, e mais de $75 \%$ dos meninos e meninas relataram envolvimento em tais atividades, (MAHONEY E STATTIN, 2000).

Esses estudos também observaram que há fatores sócio-econômicos e demográficos que influenciam as crianças em atividades extra-curriculares. O envolvimento dos pais, status sócio-econômico, nível de escolaridade e morar em uma casa com pais 
casados contribuiu positivamente para a participação em atividades extra-curriculares (HUEBNERE MANCINI, 2003). As diferenças de gênero também contribuem e segundo essa pesquisa os meninos em geral participam mais, em atividades esportivas, do que as meninas.

Idade e sexo também são importantes na determinação de viagem para crianças. Em uma pesquisa sobre a influência de duas variáveis, idade e sexo, sobre a modo de viagem das crianças Hillman et al. (1990) mostrou que meninos de seis a onze são duas vezes mais propensos a se deslocar sozinho até a escola, que as meninas da mesma idade. A mesma pesquisa foi realizada em Toronto por Vliet (1983), e mostrou que os meninos que residiam em subúrbios viajavam distâncias mais longas que as meninas. Curiosamente, esta relação só se realizou nos subúrbios, e as crianças da cidade, não apresentaram essa diferença na variável distância de viajem.

Pesquisas como as de Diguiseppi et al., (1998) e Bradshaw e Atkins (1996), afirmam que a posse de um veículo automotor tornou mais fácil aos pais deixarem seus filhos na escola. Os dados destas pesquisas revelaram que $87 \%$ dos estudantes de famílias sem carros caminhavam até a escola, por outro lado apenas $36 \%$ dos estudantes com famílias que possuiam 2 ou mais carros, se deslocavam a pé até a escola.

No Brasil existem inúmeros estudos acerca dos benefícios para a saúde ocasionados pela prática de atividade física na infância e adolescência, porém, poucos relacionam deslocamentos ativos e viagens escolares. Em um estudo sobre deslocamento ativo em adolescentes escolares do nono ano do ensino fundamental da rede municipal de Paulista (PE), Silva et al. (2014), demonstraram que dentre os escolares, $57,6 \%$ se deslocavam a pé ou de bicicleta à escola. A frequência do deslocamento ativo foi superior em escolares residentes na área rural e nos que apresentaram mãe com escolaridade superior a oito anos de estudos, o que demonstrou uma associação significativa destas variáveis com o deslocamento.

Ainda sobre deslocamento ativo até a escola, o trabalho de Silva et al. (2007), desenvolvido entre estudantes do ensino fundamental, de 7 a 12 anos de idade, na cidade de João Pessoa - Paraíba, mostrou que os estudantes mais jovens e de escolas privadas se deslocavam mais de forma passiva à escola do que os mais velhos e de escolas públicas, e que, metade dos estudantes realizavam atividades sedentárias no tempo livre, como assistir televisão ou jogar vídeo game. A pesquisa levantou que quanto maior o tempo gasto com o deslocamento de casa até a escola 
menor o número de estudantes que viajavam de forma ativa. Os pesquisadores sugerem que a infra-estrutura da cidade, localização das escolas, existência de ciclovias, segurança e condição econômica, têm influenciado a forma de deslocamento à escola. Também se faz necessário reduzir o tempo dedicado à prática de atividades sedentárias no período fora da escola e estimular a prática de esporte, principalmente nos escolares mais jovens e entre as meninas, já que as atividades sedentárias foram mais freqüentes entre o sexo feminino, escolares de 7-9 anos de idade e entre os estudantes de escolas públicas, enquanto que, a prática de esportes foi maior entre escolares do sexo masculino, faixa etária de 10-12 anos e estudantes de escolas públicas.

Em seu trabalho sobre Inatividade Física no deslocamento e comportamento sedentário em estudantes do ensino médio de Santa Catarina Silva (2012), estudou os estudantes entre 2001 e 2011 e os resultados demonstraram uma prevalência de inatividade física no deslocamento à escola que permaneceu estável de 2001 (43,7\%) a 2011 (48,7\%). Houve estabilidade no uso do transporte público (de 37,3\% para $36,1 \%)$, enquanto o uso de carro/moto aumentou de forma significativa de $6,4 \%$ para $12,6 \%$. Após uma década, observou-se aumento na prevalência dos fisicamente inativos no deslocamento. A autora utilizou regressão logística multinomial para confrontar o tipo de deslocamento. Segundo resposta do modelo, o uso de ônibus versus a pé/bicicleta foi menos provável nos jovens de áreas urbanas do que nos estudantes de áreas rurais, em famílias com renda intermediária ou alta comparados àqueles de famílias de baixa renda tiveram maior chance de se deslocar de carro/moto do que a pé/bicicleta.

\subsection{TÓPICOS CONCLUSIVOS}

Nesse capítulo foi relatado alguns trabalhos referenciais sobre as características das viagens das crianças. Pode-se observar um consenso entre os pesquisadores sobre 0 tema que o comportamento das viagens das crianças dever ser tratado de forma individual, ao invés de agrupá-las ao comportamento de viagens motorizadas dos adultos, em uma abordagem que contemple a complexa estrutura das relações que existem na decisão sobre a viagem de uma criança para a escola.

As pesquisas que tratam sobre o deslocamento das crianças até a escola iniciaram com uma preocupação latente do mundo do século XXI - o número crescente da obesidade infantil, problemas cardíacos e inatividade física entre as crianças. Esse 
problema também afetou as questões ligadas aos transportes, pois observou-se, em alguns países como os EUA e alguns países da Europa - após algumas décadas o modo de viagem das crianças foi drasticamente alterado, e o deslocamento a pé/bicicleta foi substituido pelo individual motorizado. A forma de uma criança se deslocar trata-se então, de uma questão multidisplinar já que os deslocamentos ativos (e aqui trata-se dos escolares, por ser o principal deslocamento realizado pelas crianças), pode melhorar os congestionamentos e os problemas relacionadaos a ele, como emissão de gases poluentes e ainda na saúde colaboram na prevenção da obesidade infantil e disposição das crianças para realização de suas atividades diárias.

Foi relatado também que existem muitas características do desenho urbano que afetam o deslocamento a pé/bicicleta até a escola, no entanto, outros fatores que não são da forma urbana, também influenciam a escolha do modo até escola (fatores psico-sociais). Esses fatores aparecem no modelo desenvolvido po McMillan (2003) como mediadores e moderadores, e que serviu de referência para este trabalho. 0 modelo pressupõe que até uma certa idade, a decisão final sobre o modo de viagem de uma criança até a escola é dos pais ou cuidadores, e dessa forma a tomada de decisão dos pais pode ser vista como uma variável intermediária ou mediadora entre a forma urbana e o comportamento de viagem da criança.

O conceito de uma variável mediadora está ligado à uma suposição de relacionamento entre as variáveis envolvidas, e as selecionadas para este trabalho foram: segurança do bairro, segurança do tráfego e opção de transporte no domicílio. A percepção que um pai tem sobre a segurança do tráfego, por exemplo, pode influenciar a escolha do modo do filho se deslocar até a escola, e mesmo não sendo uma questão da forma urbana, alto volume de tráfego, sugere ao cuidador uma sensação de rua perigosa e, portanto, sem condição adequada para o deslocamento a pé/bicicleta por crianças. A variável moderadora relaciona-se com determinados fatores circunstanciais que podem aparecer no meio de uma investigação e muitas vezes passam desapercebidos, no entanto, causam desvios, moderando ou alterando os resultados. As variáveis moderadoras selecionadas para este trabalho foram: Atitude dos Pais e Variáveis Sócio demográfica. Por exemplo, o número de filhos em um domicílio, não é uma questão da forma urbana, no entanto, podem modificar como os pais decidem se deslocar até a escola. 
Nos trabalhos que relacionam forma urbana e deslocamento escolares podem ser destacados dois trabalhos, que estudaram as questões do desenho urbano e viagens das crianças: 1 - McMillan (2003) - cujo modelo evidenciou que a probabilidade do deslocamento das crianças ser afetado por outros fatores é maior que os da forma urbana; McDonald (2005) - identificou o fato que a maioria das crianças não viverem à uma distância satisfatória de suas escolas é o principal fator para o aumento do uso de automóveis nas viagens escolares.

Os trabalhos que abordam deslocamentos a pé/bicicleta/ônibus, em sua maioria, revelam uma relação entre a forma urbana e esses deslocamentos. No entanto quando se trata de viagem escolar, essa relação se revela mais modesta. Ainda há muito o que se pesquisar, principalmente as questões ligadas ao comportamento e seus fatores influentes. Avançar na discussão sobre a relação entre forma urbana e deslocamentos das crianças em uma cidade brasileira, visa contribuir para uma melhor prática e intervenção de políticas públicas.

No Brasil não existem pesquisas que relacionam forma urbana e deslocamento de crianças até a escola. Existem um número de pesquisas sobre deslocamento ativo de crianças até a escola, no entanto, são pesquisas sobre saúde e obesidade infantil, e não contemplam a forma urbana como hipótese para os deslocamentos a pé/bicicleta/ônibus até a escola, fato esse que reforça a originalidade e relevância desta Tese. 


\section{Modelos para}

Análise

Comportamental 


\subsection{MODELOS PARA ANÁLISE COMPORTAMENTAL}

\subsection{BASES TEÓRICAS DOS MODELOS}

Um dos argumentos utilizados nos modelos comportamental é a de que o indivíduo estabelece subjetiva e objetivamente um elenco de opções ou alternativas na ordem de sua preferência, e escolhe sempre a que mais lhe agrada, dado um conjunto de inclinações (gastos) e dados as condicionantes de ordem econômico-financeira e de oportunidades disponíveis (NOVAES, 1986). A rápida expansão dos centros urbanos impõe à população uma série de escolhas para realizar seus deslocamentos diários, e a escolha do modo de transporte é um deles.

Buscando-se prever a opção dos usuários por um modo de transporte utilizam-se, comumente, os modelos comportamentais de escolha discreta. Estes modelos pressupõe a opção modal do indivíduo com base na agregação de diversas variáveis explicativas. As variáveis explicativas buscam definir as alternativas de modos de transporte disponíveis ao indivíduo para realização da viagem. Quando na definição do modelo estatístico que melhor explica o problema a ser estudado define-se a estrutura que melhor se ajusta as características do problema (modelo binomial ou multinomial). Define-se um conjunto de variáveis explicativas a serem utilizadas e, por último, especifica-se o conjunto de escolhas individuais que representam as alternativas disponíveis ao indivíduo para a realização da viagem.

No que tange aos fatores que influenciam o indivíduo a optar por um ou outro modo de transporte, têm-se uma diversidade de variáveis que podem ser citadas como: a velocidade, o conforto, a conveniência, o custo, a confiabilidade de cada modo, o comprimento e o motivo da viagem, as características socioeconômicas do indivíduo que irá realizar a viagem, etc. Em se tratando de modelos de escolha modal, os modelos comportamentais ou de escolha discreta são os mais usuais.

A hipótese básica desses modelos é que "a probabilidade de um indivíduo escolher uma determinada alternativa é função da atratividade da alternativa escolhida em relação à atratividade das alternativas disponíveis" (ORTÚZAR E WILLUMSEM, 1994). A atratividade de uma alternativa é representada através do conceito de "função utilidade", que é definida pela combinação de variáveis que representam as características das alternativas ou do indivíduo. Normalmente uma função utilidade é apresentada na seguinte forma: 
Os coeficientes da equação 4.1 , identificados como $\beta_{1}, \beta_{2} \ldots \beta_{n}$, representam o peso relativo de cada uma das variáveis no momento da escolha do indivíduo por um determinado modo de transporte e podem representar também as características do indivíduo que utiliza determinado modo. Na estatística são conhecidos também como estimadores. A constante $\beta_{\circ}$ que aparece no início da equação, denominada intercepto, representa a influência das características do indivíduo ou da alternativa de transporte que não foram incluídas na função utilidade.

Para se prever a escolha do modo de transporte, o valor de utilidade deve ser comparado com os valores de utilidade das outras alternativas e transformado em uma probabilidade entre 0 e 1 . Utiliza-se, normalmente, uma transformação do tipo Logit que pode ser generalizada pela equação 4.2:

$$
P 1 i=\frac{\exp (U 1 i)}{\exp (U 1 i)+\exp (U 2 i)}
$$

Onde:

$\mathrm{P} 1 \mathrm{i}=$ probabilidade de o indivíduo i optar pelo modo 1;

$\mathrm{U} 1 \mathrm{i}=$ utilidade do modo 1 para o indivíduo $\mathrm{i}$

$\mathrm{U} 2 \mathrm{i}=$ utilidade do modo 2 para o indivíduo $\mathrm{i}$

A regressão logística é muito utilizada para análise de pesquisas que apresentam variáveis resposta categóricas em que o interesse seja o de descrever a relação entre a variável resposta e um conjunto de variáveis explanatórias ou covariáveis. Quando a variável resposta é dicotômica, possuindo assim duas categorias, a regressão é denominada "logística dicotômica". Para variáveis resposta com mais de duas categorias, a denominação utilizada é regressão logística politômica.

As categorias utilizadas podem ser do tipo ordinais ou nominais. Quando a resposta é nominal, os modelos são ajustados para logitos generalizados. Comumente representam-se os modelos de escolhas individuais através de modelos logit binomial simples. Nestes modelos escolhe-se o conjunto de variáveis explicativas e o conjunto de escolhas individuais. 
O conjunto de variáveis explicativas é composto pelas variáveis que realmente vão compor a função utilidade de um modelo de escolha discreta. A definição destas variáveis é obtida por revisão bibliográfica e a possibilidade de obtenção dos dados necessários, nas condições específicas do objeto estudado. Já no conjunto de escolhas individuais ou de alternativas disponíveis, são incluídas as alternativas que realmente são consideradas pelo indivíduo, mesmo que inconscientemente. Deve-se analisar estas variáveis com muito critério, pois algumas que, numa primeira análise sendo ignoradas, podem ser importantes para que não haja distorções nos resultados do modelo.

Nessa tese as variáveis levantadas foram de: forma urbana (através de levantamento in loco e mapas digitais), percepção dos pais sobre a forma urbana da cidade de Goiânia, fatores moderados e mediadores (através de questionário aplicado aos mesmos), conforme é mostrado no Capítulo 5 (Aspectos Metodológicos).

Após o processamento do modelo parte-se para etapa de calibração e validação dos resultados. Esta etapa visa identificar a melhor resposta que representa a opção dos indivíduos entre os modos de transporte disponíveis. Geralmente a avaliação de um modelo de escolha discreta do tipo Logit é baseada em dois parâmetros estatísticos: o teste-t e o índice $\rho^{2}$.

O teste-t avalia se a variável em questão contribui de forma significativa para o poder de explicação do modelo. Valores do teste-t maiores que 1,96 (em módulo) significam que a variável tem um efeito significativo e deve ser incluída no modelo (com um nível de confiança de 95\%). O índice $\rho^{2}$ avalia o ajuste geral do modelo e varia entre 0 (nenhum ajuste) e 1 (ajuste perfeito). Valores de $\rho 2$ da ordem de 0,40 representam um bom ajuste (ORTÚZAR E WILLUMSEM, 1994). Em geral, são analisados também os sinais dos coeficientes das variáveis para verificar se estão de acordo com a teoria e o esperado. Por exemplo, uma variável que se espera que contribua positivamente para a utilidade de um modo de transporte deve ter um coeficiente com sinal positivo e, ao contrário, a não contribuição possui um sinal negativo.

\subsection{CARACTERÍSTICAS DOS MODELOS DE ESCOLHA DISCRETA}

Segundo Ben-Akiva e Lerman (1985), o princípio dos modelos de escolha discreta é a calibração da função utilidade, ou seja, calibrar o valor que o indivíduo atribui a um 
produto ou serviço pela combinação de fatores, de forma que esse valor corresponda ao máximo no conjunto de opções que estão à sua disposição. O modelo permite captar a significância das variáveis explicativas e a relação destas com a variável explicada.

A função utilidade exprime matematicamente as preferências manifestadas e podem ser usadas para representar o nível de satisfação alcançado pelo indivíduo ao utilizar-se de um ou outro modo de transporte. Os valores desta função utilidade permitem estabelecer uma comparação entre a utilidade proporcionada aos usuários pelos diferentes modos de transportes disponíveis para o seu deslocamento. Assim, a partir da definição da função que relaciona os atributos de um produto com a sua utilidade resultante pode-se estimar o comportamento do consumidor diante das alternativas disponíveis.

De uma forma geral, na construção de modelos de escolha discreta que são representados por uma função utilidade, determina-se a importância relativa dos atributos incluídos no experimento e os valores de tempo. Posteriormente especifica-se a função utilidade para modelos de predição e, finalmente, obtém-se o valor da função utilidade.

\subsubsection{Tipos de Modelos de Escolha Discreta}

Dos modelos de escolha discreta, os mais utilizados são: Modelo Logit Multinomial, Modelo Logit Aninhado, Modelo Probit Multinomial, Modelo Generalizado de Extremo Valor e ainda a Escolha por Eliminação e Satisfação.

O modelo logit, pode ser retratado da seguinte forma: Multinomial (o logit binomial é um caso particular do logit multinomial para quando existem unicamente duas alternativas, por exemplo, deslocamento a pé ou bicicleta) e o Logit Aninhado. O Modelo Logit Multinomial é o modelo de escolha discreta simples e mais popular (ORTÚZAR E WILLUMSEN, 1994). Nesta forma de modelo logit os modos de transporte considerados são representados como alternativas individuais para o viajante, conforme mostrado nas Figuras 4.1 e 4.2

Segundo Deus (2008), o Modelo Logit Aninhado, é uma extensão do modelo logit multinomial designado a capturar correlações entre as alternativas. Ele difere do modelo multinomial pelo fato de ser possível o agrupamento de alternativas que sejam similares em um mesmo "ninho". No Modelo Logit Aninhado passa a haver então níveis hierárquicos diferentes para se fazer a estimativa do modelo. A Figura 4.3 exemplifica o modelo. 


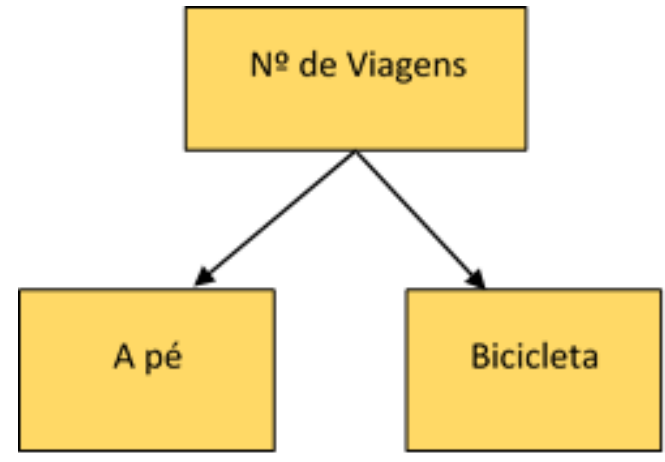

Figura 4.1 - Modelo Logit Binomial

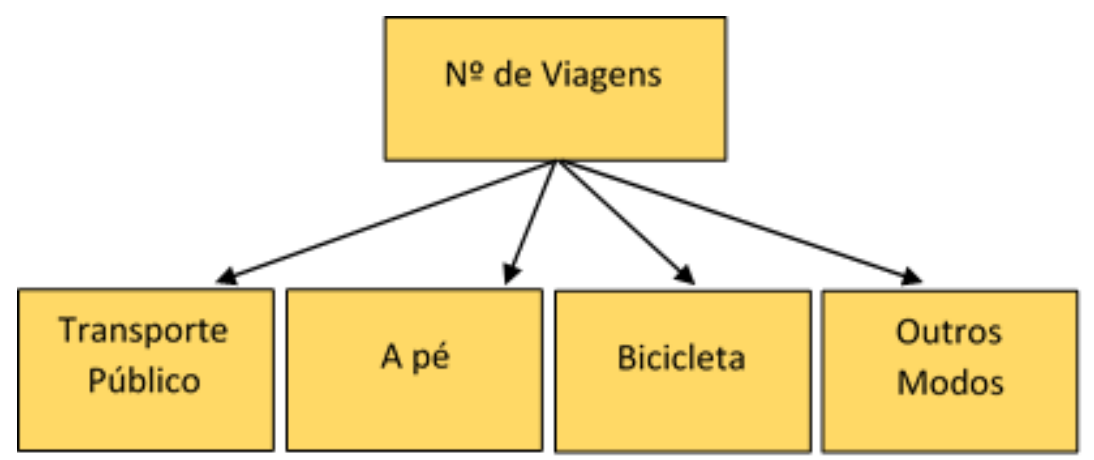

Figura 4.2 - Modelo Logit Multinomial

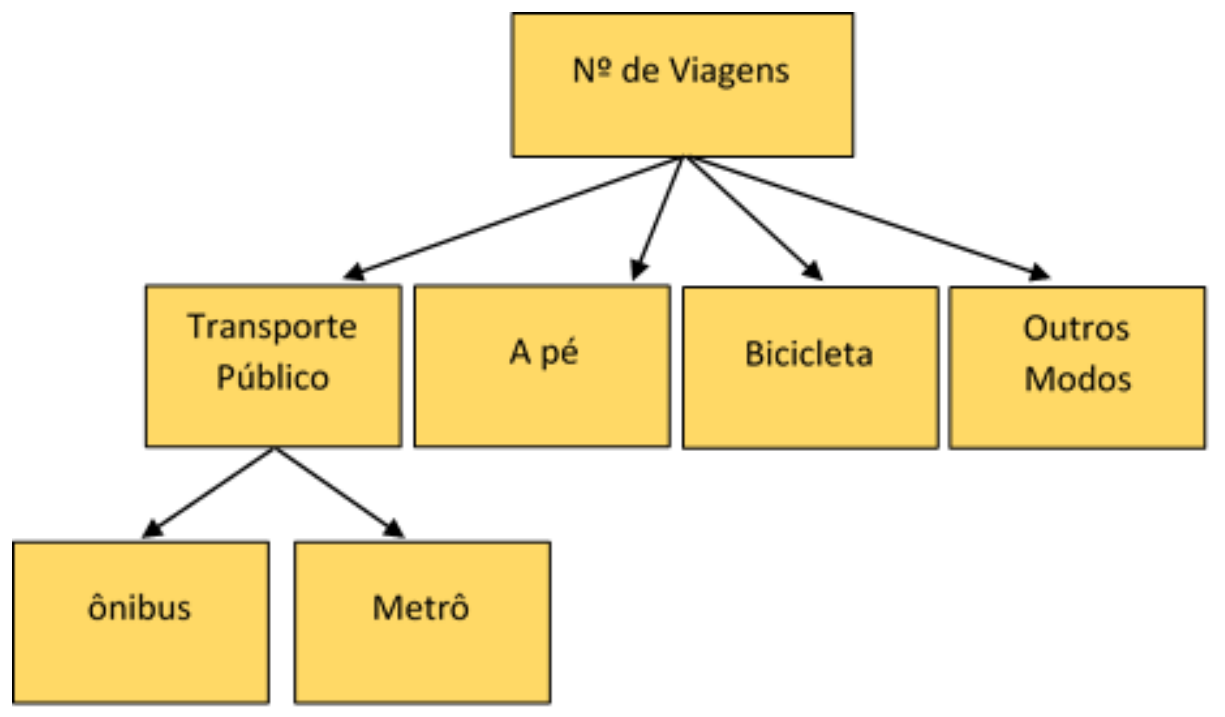

Figura 4.3 - Modelo Logit Aninhado 


\subsection{MODELOS DE REGRESSÃO LOGÍSTICA MULTINOMIAL}

Quando se pretende analisar dados em que as categorias da variável resposta são nominais, os modelos devem ser ajustados para logitos generalizados. O logito generalizado é definido por:

$$
\operatorname{logit}_{h i k}=\log \left[\frac{\pi_{\text {hik }}}{\pi_{\text {hir }}}\right]
$$

Para $k=1,2, \ldots,(r-1)$, sendo $r$ o número de categorias da variável resposta. Cada logito é obtido a partir da probabilidade de cada categoria sobre a da última categoria de resposta. Com a equação 4.3, encontrar o logithik é encontrar a função utilidade já apresentada no item anterior.

Os modelos que utilizam o logit multinomial são estimados com base no algoritmo de máxima verossimilhança, que estima o conjunto de parâmetros relativos ao ajuste do modelo. O ajuste por máxima verossimilhança tem por objetivo obter, a partir de uma amostra, as estimativas de parâmetros estatísticos, assegurando consistência, eficiência e ajuste dos parâmetros do modelo. Entretanto, para que o processo de estimação de máxima verossimilhança seja confiável, exigem-se grandes amostras a estudar.

Posteriormente, realizam-se testes estatísticos para avaliar a significância dos parâmetros dos modelos calibrados no programa. No presente trabalho esta avaliação foi feita utilizando-se a estatística de Wald (W) e a razão de chances (odds ratio).

A estatística de Wald (W) constitui uma importante estatística para avaliar a significância do logit. A estatística W é uma alternativa comumente utilizada para testar a significância individual dos coeficientes de cada variável independente. As hipóteses que são consideradas são as mesmas para o teste da razão de verossimilhança, ou seja, o teste compara a estimativa da máxima verossimilhança do coeficiente da inclinação da reta $\beta 1$ com uma estimativa do seu erro padrão. O resultado, sob a hipótese nula que $\beta 1=0$ seguirá uma distribuição normal padronizada. O teste de Wald é usado para examinar restrições impostas aos coeficientes da regressão e calcula uma estatística que mede a eficiência das estimativas dos coeficientes da regressão original em satisfazer as 
restrições da hipótese nula. Assim, o teste de Wald é utilizado para testar a significância estatística de cada coeficiente ( $\beta 1$ ) no modelo (Figueira, 2006).

Outro parâmetro muito utilizado na interpretação das regressões multinomiais é denominado de Razão de Chances ou Odds Ratio. A odds ratio (OR) é uma medida que descreve a intensidade de associação ou as chances maior ou menor de uma variável de um determinado grupo apresentar uma resposta em relação a outro grupo. Quando $\mathrm{OR}=1$, não existe associação entre as variáveis estudadas. Se, no entanto, $O R>1$, um determinado grupo tem chance maior de apresentar a resposta que outro grupo comparado. Consequentemente, se $\mathrm{OR}<1$, um determinado grupo tem chance menor de apresentar a resposta em relação a outro grupo comparado. Numa análise de regressão, a OR representa a exponencial dos estimadores encontrados sendo que, se positivo, representa um aumento de chance e, se negativo, uma diminuição de chance. Nos capítulo seguintes estes conceitos serão utilizados na interpretação dos resultados obtidos no modelo.

\subsection{O SOFTWARE RStudio}

O programa $\mathrm{R}$ utilizado neste trabalho trata-se de um software livre e de código aberto, muito utilizado na análise de gráficos e cálculos estatísticos. O programa tem a vantagem de poder ser instalado em diferentes sistemas operacionais, incluindo 0 Windows, o Linux, Macintosh e outros. O RStudio é uma interface do software estatístico $R$, uma ferramenta amigável e de fácil utilização levando o usuário a explorar mais rápido seus recursos e diminuindo a possibilidade de erros na escrita da programação dos scripts criados.

O software RStudio possui uma tela principal disposta em 4 janelas que pode ser visualizada na figura 4.4. No canto superior à esquerda é apresentada a janela Source na qual são disponibilizados os scripts (códigos de programação previamente redigidos e salvos em arquivo com extensão .R), arquivos de texto, documentos Sweave, documentação do $\mathrm{R}$ e documentos TeX. Na janela superior à direita, a primeira aba é disponibilizada para gerenciar diferentes áreas de trabalho. Já na segunda aba desta janela fica registrado o histórico de todos os scripts, funções e ações executadas. 


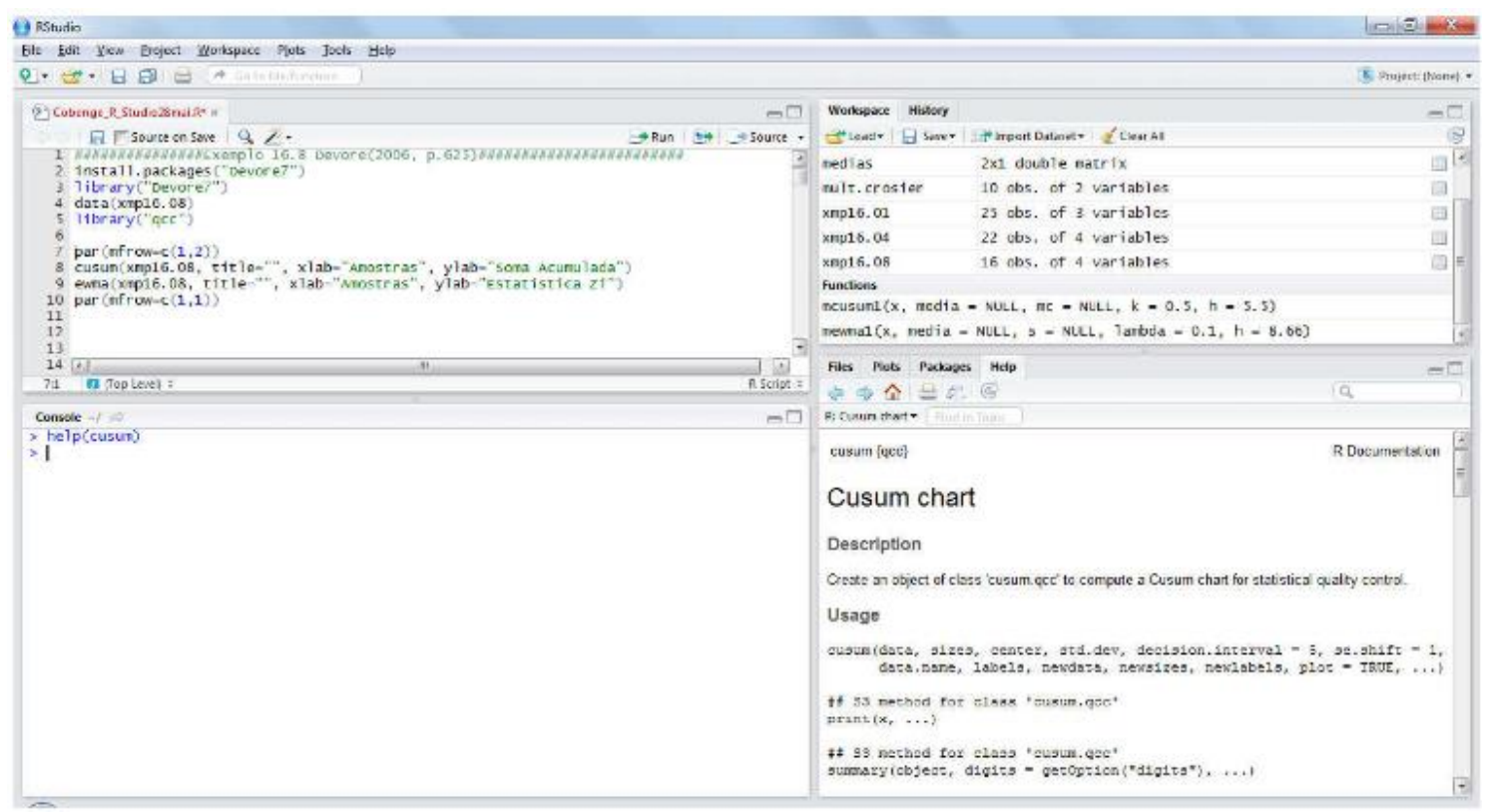

Figura 4.4 - Visão da Tela Principal do RStudio

Na parte inferior à esquerda, localiza-se a janela do console, a mesma janela padrão disponibilizada no R. E finalmente, na janela inferior a direita, são agrupadas em uma janela outras 4 abas: a primeira delas é um gerenciador de arquivos (abaFile), na segunda são exibidos os gráficos gerados pelo RStudio (abaPlots). Na terceira aba são apresentados os pacotes já instalados (abaPackages). E finalmente, a quarta aba tratase da Ajuda (abaHelp) do RStudio.

Os dados a serem analisados e organizados previamente numa planilha excel são importados para o software RStudio objetivando a confecção do modelo de regressão, processamento e geração dos resultados para avaliação. No anexo B estão disponíveis as listagens dos arquivos de saída obtidos com o processamento do modelo utilizando o software RStudio.

\subsection{TÓPICOS CONCLUSIVOS}

Neste capítulo foram apresentadas as bases teóricas utilizadas no confecção do modelo de regressão logística multinomial além das características do software estatístico Rstudio. A utilização de um modelo logístico é imprescindível numa análise comportamental mesmo levando-se em consideração um número significativo de variáveis.

Utilizando-se de um modelo logit multinomial é possível correlacionar as variáveis envolvidas no problema e avaliar a influência das mesmas sobre o padrão de escolha do modal pelos pais na condução do filho até a escola. As respostas obtidas são de 
grande importância principalmente para o poder público no direcionamento dos investimentos em modos de transporte e, sobretudo, nos modais mais sustentáveis como o caminhamento, a bicicleta e o ônibus. 
ASPECTOS

METODOLÓGICOS 


\subsection{ASPECTOS METODOLÓGICOS}

Neste capítulo será apresentado todos os procedimentos realizados para obtenção dos dados relevantes ao estudo e os resultados da análise exploratória dos mesmos. Para realização do estudo de caso foi escolhida a cidade de Goiânia-GO, parte pela facilidade de obtenção dos dados, já que a autora desta Tese além de ser professora e residente na cidade, tem contato com os órgãos de transportes da mesma.

\subsection{METODOLOGIA UTILIZADA}

A metodologia utilizada neste trabalho está mostrada na figura 5.1. Percebe-se que, assim, como no trabalho de McMillan (2003), essa pesquisa explora como a forma urbana influencia o comportamento de viagem das crianças, examinando a natureza e forma das relações entre a forma urbana, fatores sociais/econômicos e demográficos na tomada de decisões dos pais em relação a escolha do modo de viagem dos seus filhos até a escola. Nessa pesquisa as análises dos resultados estão entre três variáveis de estudo:

a) Escolha modal: deslocamentos a pé, bicicleta e ônibus do transporte público

b) Dados da forma urbana: desenho urbano e disponibilidade de transporte coletivo

c) Dados externos a forma urbana: fatores moderados e fatores mediadores

À semelhança da pesquisa de Mcmillan (2003), a estrutura desta tese está baseada na relação entre a forma urbana e comportamento de viagem, incluindo a identificação e o papel de outros fatores externos como em Handy (1996) e que influenciam a decisão de viagem ( o modelo de Handy e Mcmillan está descrito no capítulo 3). No entanto, este trabalho inseriu em seu modelo conceitual a variável transporte público na escolha modal, isso por que, tal análise, até a conclusão do trabalho, ainda não foi utilizada em nenhum outro estudo. Os dados coletados para a forma urbana também foram modificados em relação ao proposto por Mcmillan e a variável disponibilidade de transporte coletivo foi inserido nos dados da forma urbana. 


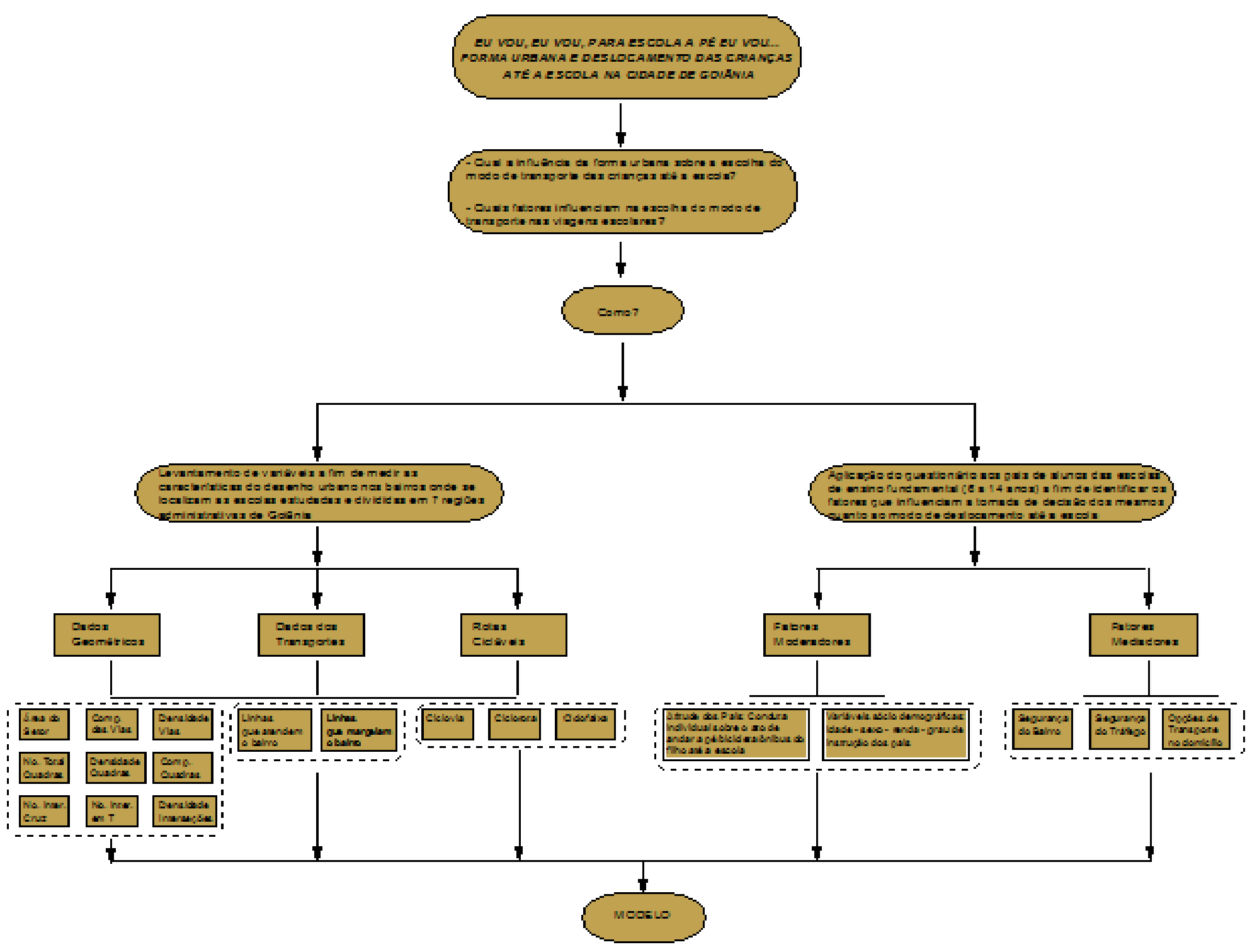

Figura 5.1 - Metodologia Empregada no Trabalho 
Pode-se observar no modelo da figura 5.1, que as variáveis coletadas foram divididas entre as da forma urbana (descritas no capítulo 2) e os fatores moderadores e mediadores (descritos no capítulo 3). Para testar a influência da forma Urbana sobre a escolha do tipo de veículo nos deslocamentos escolares, foram levantadas variáveis do desenho urbano (dados geométricos), dados do transporte público e rotas cicláveis, já utilizados em outros trabalhos como Handy (1996a), Cervero e Kockelman (1997), Cervero et al. (2009), Krizek (2003), Handy et al. (2006) e Mcmillan (2003), descritos no capitulo 2 desta Tese. Essas variáveis serão detalhadas no ítem 5.4.

Ainda na figura 5.1, pode-se observar que dentre as variáveis moderadoras foram levantadas: Atitude dos pais (percepção e conduta dos pais sobre o modo de deslocamento a pé, bicicleta ou ônibus do filho até a escola) e variáveis sóciodemográficas (idade, sexo, renda da família, estado civil, grau de instrução dos pais, número de automóveis na família, número de pessoas habilitadas na família). Já as variáveis mediadoras estudadas foram: segurança do bairro, segurança do tráfego e opções de transporte no domicílio).

\subsection{DELIMITAÇÃO DA ÁREA DE ESTUDO}

A cidade de Goiânia, capital do Estado de Goiás, está localizada na região central desse estado. Sua população, segundo dados SEMDUS (2013), era de 1.393.579 habitantes no ano de 2013. O Município de Goiânia é organizado em sete regiões administrativas ${ }^{1}$, segundo a Prefeitura de Goiânia em: Campinas-Centro, Leste, Oeste, Sudoeste, Sul, Noroeste e Norte, conforme apresenta a figura 5.2.

\footnotetext{
${ }^{1}$ A divisão em sete regiões administrativas que foi considerada nessa Tese é a divisão mais recente (2010), adotada pela Prefeitura de Goiânia, no entanto até esta data, dezembro (2016) não foi oficialmente consolidada.
} 


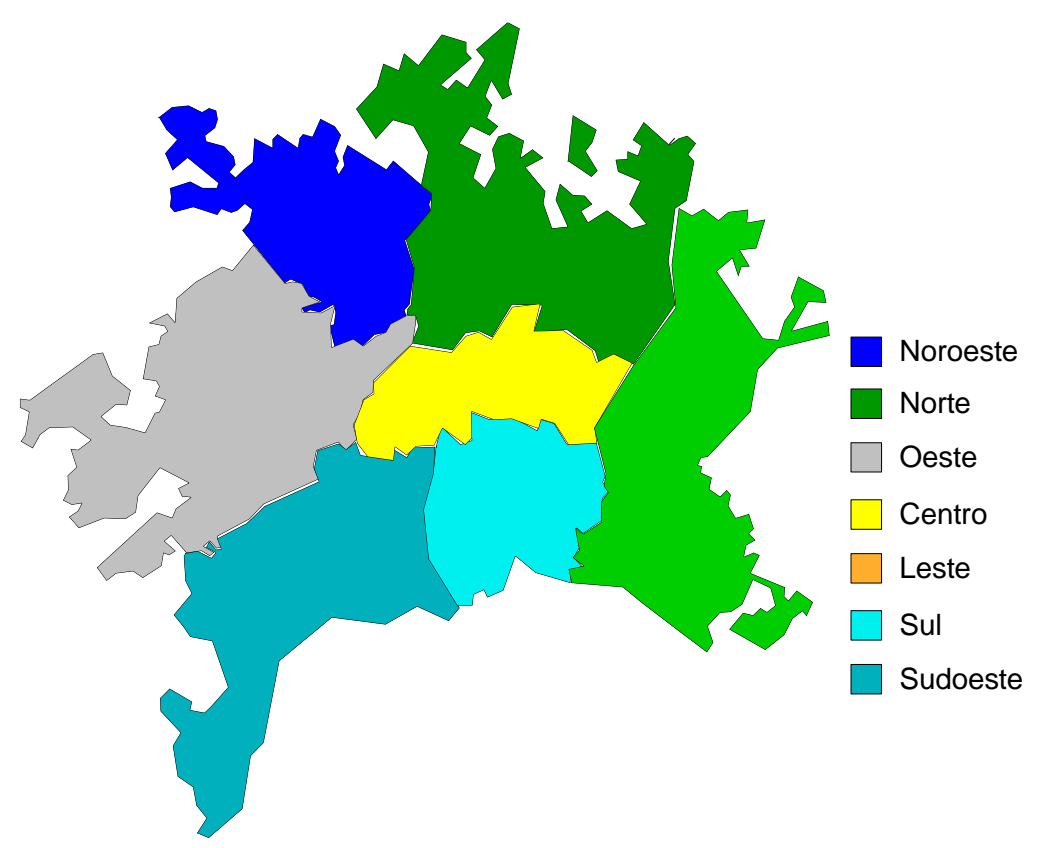

Figura 5.2 - Perímetro Urbano e as sete Regiões Administrativas de Goiânia.

\subsubsection{Sobre a Cidade de Goiânia}

Goiânia nasceu do desejo de mudança da antiga capital do Estado - Vila Boa - para uma nova cidade. A antiga capital estava localizada em uma região montanhosa que acarretava vários problemas logísticos, e o desejo de deslocar a sede do Governo eram decorrentes desde o período colonial. A ideia de mudança da capital foi finalmente concretizada por Pedro Ludovico Teixeira apoiado por Getúlio Vargas, sob a tutela de Marcha para o Oeste. (MANSO, 2013)

O interventor Pedro Ludovico Teixeira assumiu o governo do Estado em 22 de novembro de 1930, iniciando a partir dessa data seu plano de mudança da nova capital. Em 20 de dezembro nomeou uma comissão de pessoas habilitadas para iniciar os estudos para escolha do sítio onde se construiria a nova capital. Em 1933, Attílio Corrêa Lima iniciou os projetos urbanísticos de Goiânia, que segundo Decreto n 3.359 deveria ser localizada nos arredores de Campinas no Sul de Goiás. (RIBEIRO, 2004)

O arquiteto Attílio Corrêa Lima foi responsável pelas primeiras ideias e pelos primeiros desenhos da cidade que acabaram se materializando nos setores central e norte. No entanto, o arquiteto não deu continuidade nos projetos e afastou-se em 1935, sendo substituído pelo engenheiro Armando de Godoy. $O$ engenheiro foi o responsável por 
todas as modificações realizadas nos desenhos originais de Attílio Correa Lima, que culminou na aprovação do Plano de Urbanização de Goiânia em 1938, pelo Decreto-lei municipal 90-A. (GONÇALVES, 2003).

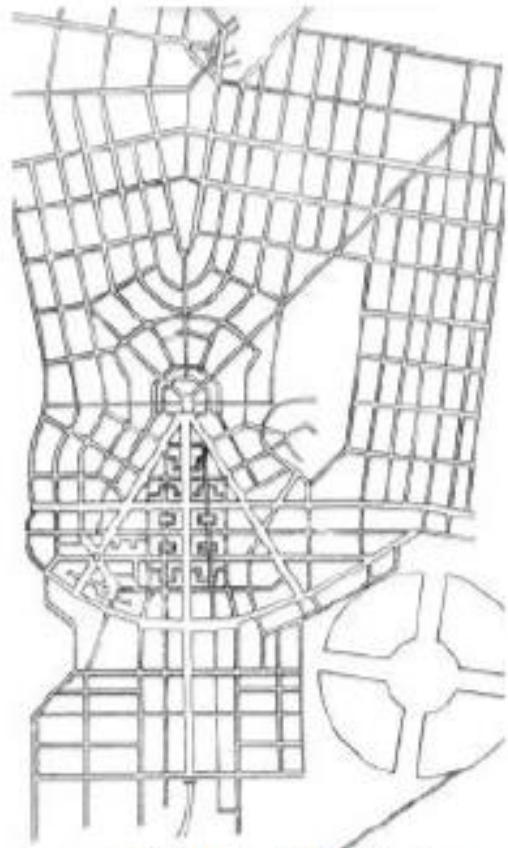

Figura 1: Plano de Attilio Corrêa Figme

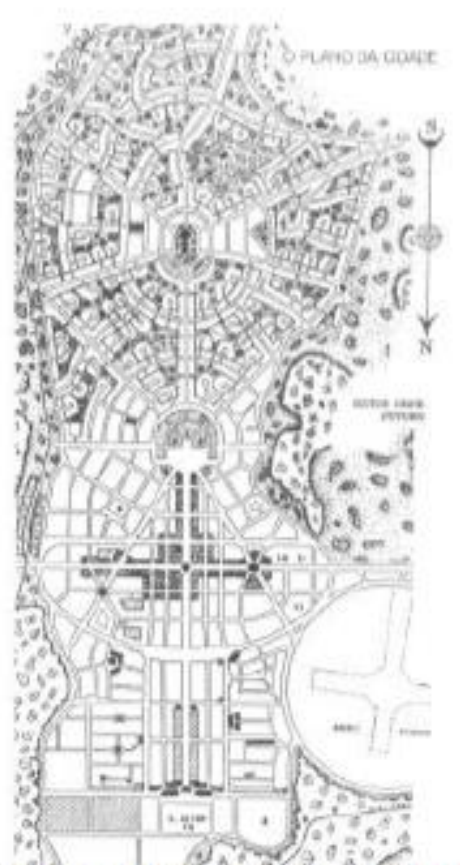

Figura 2: Plano alterado por Armando de Godoi Goiânia: 50 nos. Brasihia MEC-SESU, 1985.

Figura 5.3 - Planos Atílio Corrêa Lima e Armando Godoi Fonte: Gonçaves (2003)

Segundo Ribeiro (2004), Goiânia teve em sua história cinco planos diretores, que orientaram seu desenvolvimento e crescimento, apesar da história oficial da cidade contar apenas quatro. Segundo a autora, são eles:

1. Concluído e oficializado em 1938, iniciado pelo arquiteto e urbanista Attílio Corrêa Lima (1933-1937) e finalizado pelo engenheiro urbanista Armando Augusto de Godói (1935-1937);

2. Desenvolvido pelo arquiteto Luís Saia (1959-1962), não oficializado devido ao momento político da Revolução de 1964;

3. Elaborado pelo arquiteto e urbanista Jorge Wilheim (1967-1969);

4. Desenvolvido pela Engevix Engenharia S.A (1989-1992) e oficializado em 1994;

5. Lei complementar $n^{\circ} 171$ de 29/05/2007 - Plano Diretor de Goiânia atual.

O primeiro plano de Goiânia foi utilizado e aplicado até o início dos anos 50, com exceção da ocupação do leste da cidade compreendida pelos bairros Vila Nova, Botafogo e Nova Vila, ocupados pelos construtores da cidade e cuja moradia deveria ser provisória, no entanto se tornaram definitivos e regularizados entre 1947 e 1954. A 
forma como a cidade deveria crescer estava descrita no plano, no início, seriam ocupados somente os setores central e norte, após seis anos poderia ser iniciada a ocupação dos setores sul e oeste. Em todos esses bairros, o desenho seguia a topografia do terreno, e optou-se por uma malha ortogonal tipo "tabuleiro de xadrez".

Nesse período o parcelamento do solo de Goiânia era regido pelo seu plano original e era uma atribuição do Estado. A mancha urbana restringia-se a Campinas e ao Setor Central, compreendendo também os Setores Sul, Oeste e Norte (Bairro Popular). A ocupação do Leste como citado acima extrapolava os limites do desenho original.

No início da década de 50, o poder público, pressionado pelos proprietários das glebas lindeiras da zona urbanizada, rendeu-se as pressões dos empreendedores imobiliários, e foi exigido à estes apenas a locação dos lotes e a abertura de vias (ficando desobrigados do calçamento de ruas, água e esgoto). A cidade cresceu desde então de uma forma vertiginosa, o que descaracterizou o plano inicial. Entre 1950 e 1964, foram aprovados 183 loteamentos que não obedeciam a nenhum critério técnico. (RIBEIRO, 2004).

O mapeamento realizado por Ribeiro (2004) mostra que, nesse período, a área parcelada da cidade cresceu surpreendentemente, incorporando os Setores Universitário, Bueno e Jardim Guanabara, entre outros. A cada nova década, novos bairros surgiam e se articulavam ao centro histórico, promovendo uma extensão da cidade contrária à concepção de seus desenhos originais.

Um novo plano oficial só foi implementado no final da década de 60 , já que o plano desenvolvido por Luis Saia, nem chegou a ser completamente desenvolvido. No novo plano de 1969, os parcelamentos realizados pela iniciativa privada não foram proibidos, no entanto, as exigências requeridas para a infra-estrutura urbana, praticamente os inviabilizava. Esse controle, fez surgir na cidade, até o final da década de 80 , vários loteamentos clandestinos e sem nenhum critério técnico.

Em 1992 foi aprovado o terceiro plano oficial de Goiânia, e para sua regulamentação, foi elaborada uma nova Lei de Uso do Solo, aprovada em 1994. Segundo dados IBGE (2010) a população de Goiânia em 1960 era de 151.013 pessoas. Em 2000 esse número aumentou para 1.093.007, como mostra a tabela 5.1, implicando em um acréscimo de 7,2 vezes em relação ao censo de 2010. Esse aumento exacerbado, transformou a cidade, fazendo com que a mesma contraísse problemas iguais às outras cidades sem 
planejamento. Segundo Medeiros (2006) a cidade cresceu como uma "colcha de retalhos", e o único traço que ficou como herança do desenho original do setor central foi a repetição de praças circulares entrelaçadas por avenidas.

Tabela 5.1 - Evolução da população de Goiânia - 1940 - 2010

\begin{tabular}{cc}
\hline ANO & POPULAÇĀO \\
\hline 1940 & 48.166 \\
1950 & 53.389 \\
1960 & 151.013 \\
1970 & 380.773 \\
1980 & 717.526 \\
1991 & 922.222 \\
1996 & 1.003 .477 \\
2000 & 1.093 .007 \\
2007 & 1.244 .645 \\
\hline $\mathbf{2 0 1 0}$ & $\mathbf{1 . 3 0 2 . 0 0 1}$ \\
\hline
\end{tabular}

Fonte: IBGE, 2010

O mais recente plano urbanístico da cidade de Goiânia resulta da Lei Complementar $n^{\circ}$ 171 , de 29 de maio de 2007 e traz em seu escopo os preceitos da cidade compacta e do novo urbanismo em suas diretrizes gerais. Em resumo a Lei abrange as seguintes temáticas: modelo espacial; perímetro urbano; macrozoneamento da área urbana e rural; macro rede viária básica; sistema de transporte coletivo; desenvolvimento econômico; programas especiais e vazios urbanos.

Dentre as principais premissas do Plano Diretor 2007 estão: a construção de uma cidade compacta e miscigenada; a construção de corredores exclusivos para o transporte coletivo; a promoção de geração de emprego e renda, fortalecendo as bacias econômicas já implantadas; a promoção de uma política habitacional de baixa renda; implantação de programas especiais para revitalização, reurbanização e requalificação urbana; incentivar projetos em áreas de interesse social; bem como uma modernização administrativa.

O município de Goiânia foi subdividido, em macrozonas construída e macrozonas rurais, como evidencia a figura 5.2. Na porção rural estão inseridos: Capivara, João Leite, São Domingos, Lajeado, Alto Anicuns, Alto Dourados e Barreiros. 


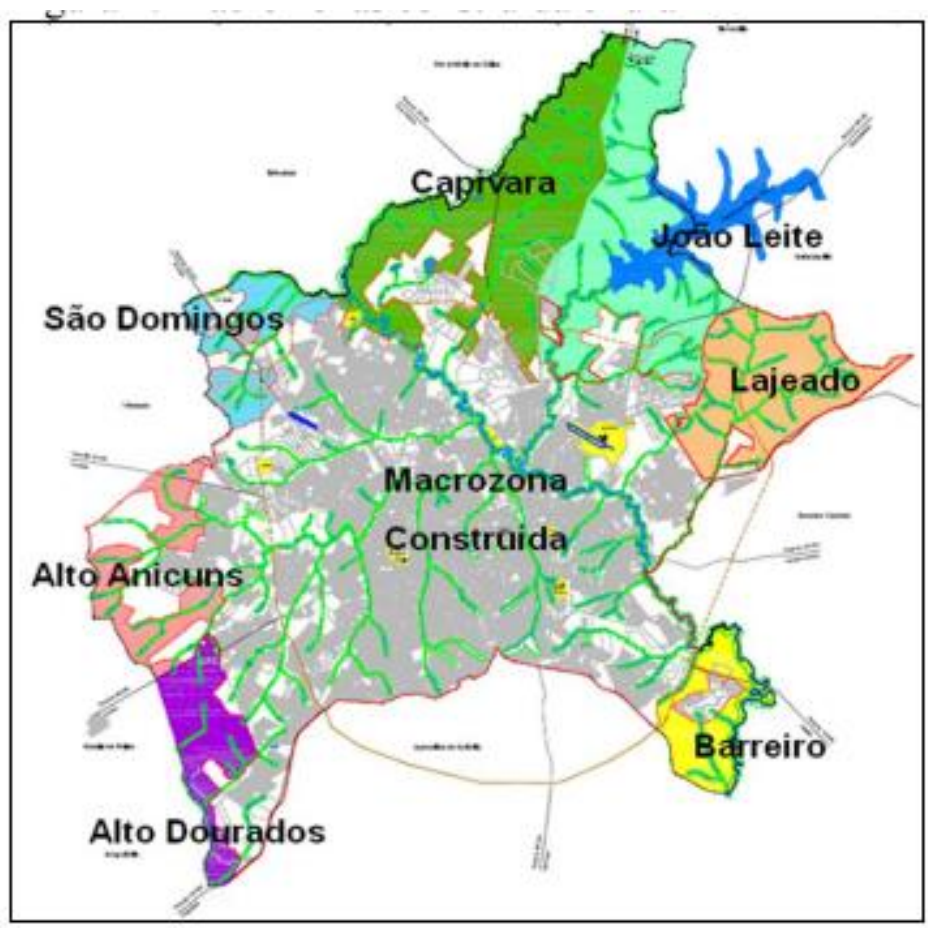

Figura 5.4 - Macrozona construída e Macrozona rural. Fonte: Plano Diretor (2007).

Foi desenvolvido um modelo espacial da área construída de Goiânia, onde consta uma subdivisão da mesma em seis áreas mostrado na figura 5.4:

1. Áreas Adensáveis: são áreas estimuladas às maiores densidades habitacionais e de atividades econômicas, sustentadas pela rede viária e de transporte;

2. Áreas de Adensamento Básico, que são áreas de baixa densidade, para as quais será admitida a duplicação dos atuais padrões de densidade, visando a correlação das funções urbanas em menores distâncias e a otimização dos benefícios sociais instalados, estando sujeita ao controle de densidade;

3. Áreas de Desaceleração de Densidade, as quais serão dirigidas ações de controle e redução do atual processo de densificação urbana. Integram essa unidade territorial os setores: Alto da Glória, Vila São João, Jardim Bela Vista, Jardim Goiás e Setor Bueno;

4. Áreas Especial de Interesse Social, são áreas que objetivam a promoção prioritária da moradia destinada à população de baixa renda;

5. Áreas de Uso Sustentável, são aquelas contíguas as APP's (Áreas de Preservação Permanente), com restrição de uso e ocupação; e por fim, as

6. Áreas de Restrição Aeroportuárias, são áreas próximas ao aeroporto de Goiânia. 


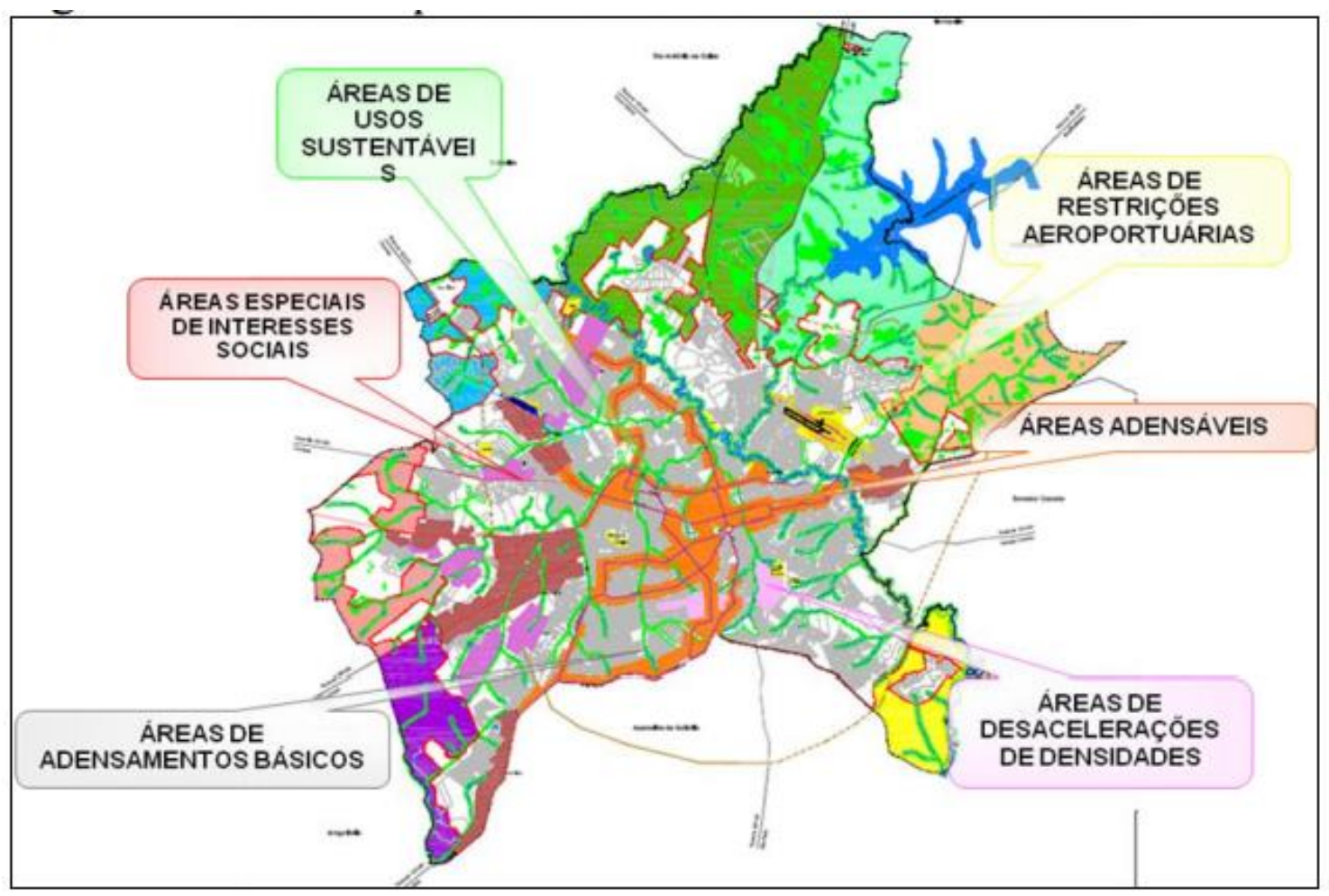

Figura 5.5 - Modelo Espacial de Goiânia. Fonte: PDG (2007)

A seguir far-se-á um breve comentário sobre alguns aspectos da política urbana que estão descritos no Plano Diretor 2007 de Goiânia.

O texto sobre política urbana aborda seis eixos estratégicos:

1. Ordenamento Territorial - O território urbano e rural do município foi dividido em macrozonas (como verificado na figura 5.2), constando na subdivisão o espaço construído e as sub-bacias hidrográficas do território com ocupação rarefeita. Como premissa de valorização de uma cidade compacta, foram priorizadas áreas de urbanização e densificação da cidade construída e ajustado os indicativos de crescimento da cidade à dinâmica de sua ocupação concêntrica. Através de instrumentos de regulação são definidos parâmetros de controle e ocupação do solo no que se refere à edificação e parcelamentos.

2. Sustentabilidade Socioambiental - Prioriza o desenvolvimento local de forma sustentável para todo o Município de Goiânia, visando a proteção, a recuperação e a manutenção dos aspectos paisagísticos, históricos, culturais, arqueológicos e científicos da cidade. O Plano prevê a implantação de programas de sustentabilidade socioambiental através dos seguintes subprogramas: 
Subprograma de Gerenciamento e Proteção Ambiental, Subprograma de Controle e Qualidade do Ar, Subprograma de Controle da Poluição Sonora, Subprograma de Controle da Poluição Visual, Subprograma de Recursos Hídricos, Subprogramas de Áreas Verdes, Subprogramas de Saneamento e Subprograma de Coleta e Destinação de Resíduos Sólidos.

3. Mobilidade, Acessibilidade e Transporte - Tem por objetivo promover ações de forma a garantir a mobilidade urbana sustentável, proporcionando o acesso amplo e democrático ao espaço urbano, eliminando ou reduzindo a segregação espacial, garantindo o desenvolvimento urbano, contribuindo para a inclusão social, favorecendo a sustentabilidade socioambiental e a acessibilidade universal. São premissas nesse âmbito do Plano: - estimular os meios não motorizados de transporte, valorizando a bicicleta como um meio de transporte e integrando-a com os modais de transporte coletivo - garantir uma rede estrutural de transporte coletivo: com corredores exclusivos, capacidade de implantação de veículos articulados, biarticulados, veículos leves sobre trilhos e modais com tecnologia metroviária. Quanto a politica voltada a acessibidade, o texto versa sobre: regulamentar e implementar ações voltadas especialmente aos portadores de deficiência física, relativa ao transporte, acessibilidade em escolas, parques, acessos a edificações, a espaços públicos e privados, garantindo sua segurança; adequar as calçadas para atender o fluxo de pedestre da cidade especialmente as pessoas portadoras de limitações locomotoras; promover a cultura da acessibilidade em todo o Município, através da implantação do programa brasileiro de acessibilidade urbana denominado Brasil Acessível.

4. Desenvolvimento Econômico - O crescimento da economia e o avanço social da população será alicerçada na conservação dos recursos naturais e do meio ambiente, em novas oportunidades empresariais e tecnológicas. A implementação das estratégias de promoção econômica dar-se-á visando: fortalecer o papel de metrópole regional na rede de cidades brasileiras; disseminar pelo território do Município as atividades econômicas; garantir a instalação das atividades econômicas pelo tecido urbano; fomentar a produção agropecuária e ordenar o abastecimento familiar; promover a geração de emprego e renda; criar mecanismo para regularizar o setor informal, estimulando a promoção dês trabalho e renda; promover o turismo como atividade geradora de emprego e renda; fomentar os comércios agropecuários, agroindustriais, de artesanato e confecção nas feiras livres do município; incentivar, estruturar e 
qualificar os feirantes e as feiras livres do município, com especial atenção a Feira Hippie.

5. Desenvolvimento Sociocultural - O Plano prevê prioridade a inclusão social da população, adotando políticas públicas que promovam e ampliem a melhoria da qualidade de vida dos seus cidadãos. Os objetivos, as diretrizes e ações estratégicas previstas no Plano são voltadas a população de baixa renda, as crianças, os adolescentes, os jovens, os idosos, os portadores de necessidades especiais, os gays, lésbicas, bissexuais e transexuais - GLBT e as minorias étnicas. As diretrizes básicas que norteiam o desenvolvimento Sociocultural do município são: a Promoção da Moradia; Educação; Saúde; Assistência Social; Inclusão Social; cultura; Esporte, lazer e Recreação; Segurança alimentar e nutricional.

6. Gestão Urbana - As estratégias da gestão urbana que são contempladas no Plano, são voltadas à produção de uma cidade sustentável, garantindo a qualidade dos serviços e participação da comunidade com espaço para deliberação sobre as políticas, planos, programas e projetos de desenvolvimento regional.

\subsection{2 - Estatística e amostra da pesquisa}

Como citado anteriormente a pesquisa foi realizada em escolas do ensino fundamental da cidade de Goiânia das redes municipal, estadual e federal. A Lei no 11.274/2006, dispõe sobre a obrigatoriedade da duração de nove anos para o ensino fundamental, iniciando a criança com seis anos completos. Segundo a mesma Lei o ensino fundamental abrange dois ciclos: Ciclo I - de 6 a 10 anos de idade, compreendendo séries de $1^{\circ}$ ao 5ํano; Ciclo II - de 11 a 14 anos de idade, compreendendo séries de 6음 ao $9^{\circ}$ ano.

Para delimitação da área de estudo, dividiu-se as escolas de ensino fundamental de Goiânia nas sete regiões administrativas, mostradas na figura 5.2. Segundo dados do Instituto Mauro Borges de estatística e Estudo Sócio econômicos IMB (2013), de 2010 a 2012, houve uma pequena variação no número de estabelecimento de ensino da cidade, como mostra a tabela 5.2. As escolas estaduais passaram de $118 \mathrm{em} 2010$ para 109 em 2012, um decréscimo de 9 estabelecimentos. Já as escolas municipais apresentaram um acréscimo de 12 escolas entre os anos 2010 a 2012. Os estabelecimentos particulares eram 351 em 2010, passaram para 337 em 2011 e perderam uma unidade em 2012 passando para 336 escolas. 
Tabela 5.2 - Total de Estabelecimentos de Ensino e Sala de Aula por tipo de vínculo - Goiânia 2010 - 2012

\begin{tabular}{|l|r|r|r|}
\hline \multicolumn{1}{|c|}{ Tipo de vínc ulo do Estabelecimento } & \multicolumn{1}{c|}{$\mathbf{2 0 1 0}$} & \multicolumn{1}{c|}{$\mathbf{2 0 1 1}$} \\
\hline Estabelecimentos de Ensino - Total (número) & $\mathbf{7 4 4}$ & $\mathbf{7 2 9}$ & $\mathbf{7 3 2}$ \\
\hline Estabelecimentos de Ensino - Federal (número) & 3 & 3 & 3 \\
\hline Estabelecimentos de Ensino - Estadual (número) & 118 & 115 & 109 \\
\hline Estabelecimentos de Ensino - Municipal (número) & 272 & 274 & 284 \\
\hline Estabelecimentos de Ensino - Particular (número) & 351 & 337 & 336 \\
\hline Salas de Aula Existentes - Total (número) & $\mathbf{8 . 3 0 4}$ & $\mathbf{8 2 6 1}$ & $\mathbf{8 . 0 6 3}$ \\
\hline Salas de Aula Existentes - Federal (número) & 77 & 78 & 76 \\
\hline Salas de Aula Existentes - Estadual (número) & 1.955 & 2.012 & 1.559 \\
\hline Salas de Aula Existentes - Municipal (número) & 2.063 & 2.079 & 2.180 \\
\hline Salas de Aula Existentes - Particular (número) & 4.209 & 4.092 & 4.248 \\
\hline Salas de Aula Utilizadas - Total (número) & $\mathbf{7 . 4 2 0}$ & $\mathbf{7 . 3 5 7}$ & $\mathbf{7 . 2 6 4}$ \\
\hline Salas de Aula Utilizadas - Federal (número) & 77 & 78 & 76 \\
\hline Salas de Aula Utilizadas - Estadual (número) & 1.627 & 1.568 & 1.274 \\
\hline Salas de Aula Utilizadas - Municipal (número) & 2.034 & 2079 & 2.191 \\
\hline Salas de Aula Utilizadas - Particular (número) & 3.682 & 3.632 & 3.723 \\
\hline
\end{tabular}

Fonte: Instituto Mauro Borges de Estatística e Estudos Socioeconômicos - IMB

Elaboração: SEMDUS/DPESE/DVPEE/DVESE

A Secretaria de Educação, Cultura e Esporte de Goiás forneceu os dados necessários para aplicação da pesquisa com os pais dos alunos das escolas do ensino fundamental. O banco de dados fornecido continha informações, como: nome da escola; endereço; telefone; nome dos diretores e coordenadores; rede de ensino federal, estadual, municipal e particular; número total de alunos matriculados por rede de ensino.

Os dados foram manipulados e as escolas do ensino fundamental separadas das demais. Escolheu-se os alunos do ensino fundamental para estudo por se tratarem de crianças com idade entre 6 a 14 anos de idade, e que por isso precisam dos pais para se deslocarem ou para escolher o melhor veículo para tanto. Segundo dados mostrados na tabela 5.3, Goiânia tem atualmente 297 escolas municipais, sendo que deste número apenas 167 são do ensino fundamental com 67.923 alunos matriculados; as escolas estaduais somam um total de 108 estabelecimentos e 92 oferecem o ensino fundamental com 25.963 alunos inscritos; das 375 unidades particulares 263 oferecem o ensino fundamental e contam com 65.288 alunos matriculados. 
Tabela 5.3 - Total de Estabelecimento de Ensino e Número de Escolas e Alunos matriculados no Ensino Fundamental em Goiânia

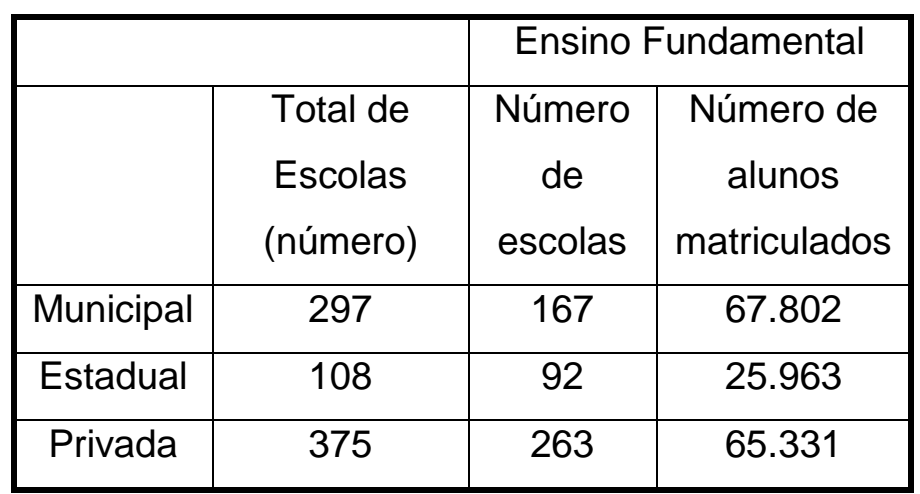

Fonte: Secretaria de Educação, Cultura e Esporte de Goiás Censo:2016

Após a separação das escolas por rede de ensino, as mesmas foram divididas por região administrativa, como mostra a tabela 5.4. Pode-se verificar pela tabela que a região Campinas Centro é a que possui o maior número de escolas - 114, enquanto que a região com o menor número de estabelecimentos do ensino fundamental é a região Noroeste com 55 escolas.

Tabela 5.4 - Total de Escolas do Ensino Fundamental por Região Administrativa

\begin{tabular}{|c|c|c|c|c|}
\hline $\begin{array}{c}\text { Região } \\
\text { Administrativa }\end{array}$ & Municipal & Estadual & Particular & Total \\
\hline Campinas centro & 36 & 24 & 54 & 114 \\
\hline Leste & 21 & 15 & 26 & 62 \\
\hline Noroeste & 12 & 14 & 21 & 47 \\
\hline Norte & 23 & 6 & 26 & 55 \\
\hline Oeste & 21 & 11 & 27 & 59 \\
\hline Sudoeste & 35 & 10 & 44 & 89 \\
\hline Sul & 19 & 12 & 65 & 96 \\
\hline Total & 167 & 92 & 263 & \\
\hline
\end{tabular}

Fonte: Secretaria de Educação, Cultura e Esporte de Goiás - SEDUCE

Para a retirada da amostra a ser pesquisada foram divididos também, o número de alunos por Região Administrativa mostrados na tabela 5.5 e na figura 5.6. 
Tabela 5.5 - Total de Alunos Matriculados do Ensino Fundamental por Região Administrativa

\begin{tabular}{|c|c|c|c|c|}
\hline \multirow{2}{*}{ Região } & \multicolumn{3}{|c|}{ Rede } & Total \\
\cline { 2 - 4 } & Estadual & Municipal & Particular & \\
\hline $\begin{array}{c}\text { Campinas } \\
\text { centro }\end{array}$ & 7161 & 13402 & 15245 & 35808 \\
\hline Leste & 3925 & 7990 & 5508 & 17423 \\
\hline Noroeste & 4753 & 4371 & 5239 & 14363 \\
\hline Norte & 1331 & 10384 & 5321 & 17036 \\
\hline Oeste & 2615 & 11336 & 5120 & 19071 \\
\hline Sudoeste & 2046 & 13710 & 9733 & 25489 \\
\hline Sul & 4132 & 6609 & 19165 & 29906 \\
\hline Total & 25963 & 67802 & 65331 & \\
\hline
\end{tabular}

Fonte: Secretaria de Educação, Cultura e Esporte de Goiás - SEDUCE

A figura 5.6 apresenta a distribuição em percentagens das escolas de ensino fundamental na cidade de Goiânia. A região identificada como Campinas-Centro possui a maior porcentagem de escolas, 22\%, com 35.808 alunos matriculados. A região com menor porcentagem de escolas de ensino fundamental foi a Noroeste (9\%), com 14.363 alunos matriculados. Três regiões administrativas possuem porcentagens próximas de escolas de ensino fundamental que são a Leste (12\%), Norte (11\%) e Oeste (11\%). As três regiões juntas possuem 53.530 alunos matriculados segundo o censo escolar de 2016. Complementando têm-se a região sul com 18\% de escolas de ensino fundamental e 29.906 alunos matriculados em 2016 e a região sudoeste com 17\% de escolas de ensino fundamental e 25.489 alunos matriculados. No ano de 2016, o censo escolar da secretaria de educação do estado de Goiás apontou 159.096 alunos matriculados no ensino fundamental, na cidade de Goiânia. 


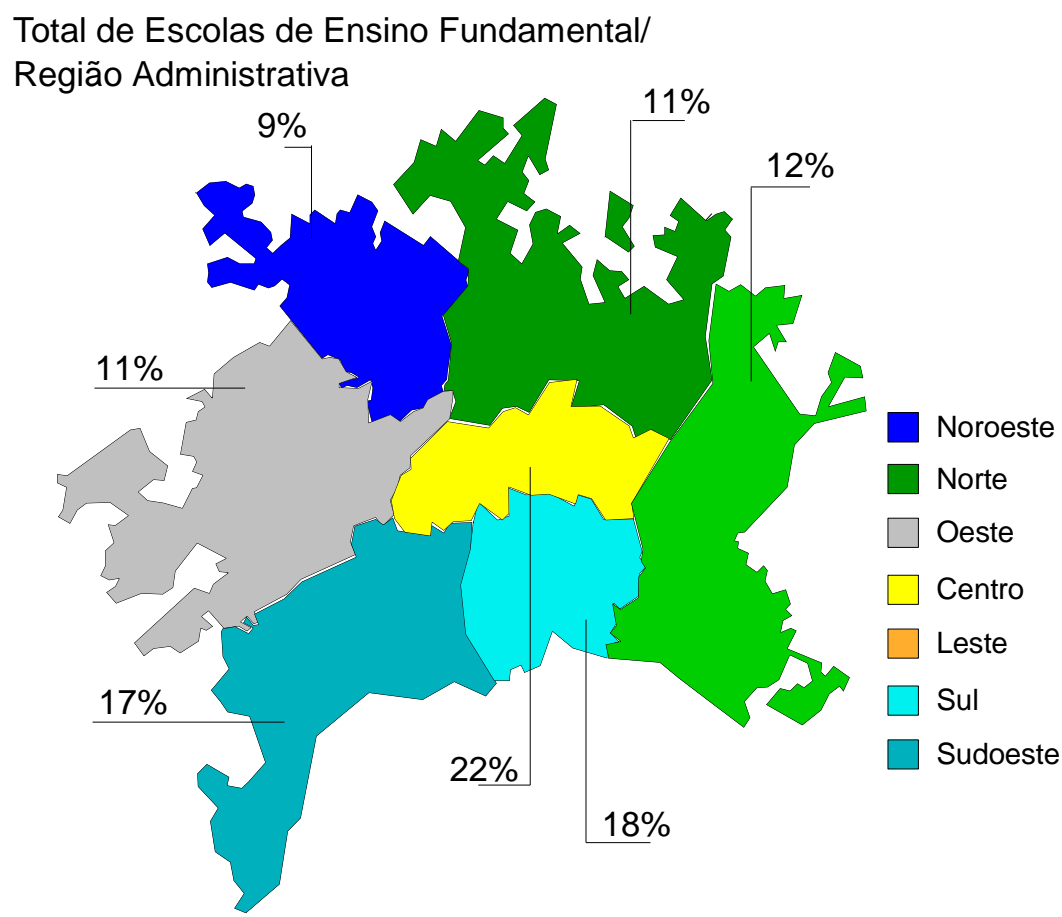

Figura 5.6 - Percentagens de Escolas do Ensino Fundamental nas sete Regiões Administrativas de Goiânia.

A partir da tabela 5.5 foram retiradas as amostras do número de pesquisas que deveriam ser aplicadas com os pais dos alunos por região administrativa. Os dados que constam na tabela 5.5 diz respeito à população dos alunos do ensino fundamental de Goiânia, separados nas redes municipal, estadual e federal. Dessa população foram extraídas amostras através da formulação apresentada na equação 5.1 :

$$
n=\frac{N \cdot z^{2} \cdot p \cdot q}{(N-1) \cdot e^{2}+z^{2} \cdot p \cdot q}
$$

Onde:

$\mathrm{n}$ - tamanho da amostra

$\mathrm{N}$ - é o tamanho da população,

$q$ - é igual a (1-p), e é a margem de erro

z - é o fator da distribuição normal padronizada correspondente ao nível de significância $\alpha$

Geralmente, o produto p.q é obtido do histórico de trabalhos anteriores ou, quando totalmente desconhecido, substituído por 0,25 - valor máximo que proporcionará um 
cálculo conservador do tamanho da amostra, e utilizado nesse trabalho para o cálculo da amostra.

A estimação de proporções ambienta-se em questões de dois tipos: dicotômicas e politômicas. As questões dicotômicas são aquelas que contêm dois itens de resposta, geralmente representadas pelo binômio sim/não. Já as questões politômicas, são compostas de questões de mais duas categorias ou classes de resposta. Nessa tese a estimação foi do tipo politômica, pois as respostas das questões do formulário aplicado, apresentaram, por muitas vezes, mais de duas categorias ou classes de resposta.

A amostra foi classificada como estratificada, e a população dividida em estratos (dentro das regiões administrativas), consideradas homogêneas dentro do estrato, e heterogêneas fora dele. Para retirada da amostra final, foi feito uma proporção dos alunos por rede de ensino e dentro dos estratos, ou região administrativa. O Anexo A-1 apresenta simulações para um nível de significância 99\%, 95\% e 90\%, e erro amostral variando de 1 a $10 \%$.

As variáveis da forma urbana, e já descritas no capítulo 2 desta tese, foram levantadas com a ajuda mapas georeferenciados da cidade em uma plataforma SIG. O software Transcad também foi utilizado para contagem das interseções em cruz e T.

A estrutura do formulário de pesquisa (Anexo A-3) foi construída de modo a identificar como a forma urbana influencia o comportamento de viagem, incluindo a identificação de outros fatores que atuam no caminho da decisão. Como descrito no capítulo 3, esse estudo sugere que existam múltiplos fatores que influenciam na decisão de como viajar até a escola (fatores moderadores e mediadores), e que a compreensão destes vai ajudar no desenvolvimento de programas e políticas de planejamento mais eficazes.

Como em McMILLAN (2002) a pesquisa com os pais se concentrou principalmente em:

1) informação dos pais sobre a viagem de seu filho para a escola e sua própria viagem;

2) percepção dos pais sobre a segurança (criminalidade e tráfego) enquanto seus filhos viajam a pé/bicicleta/ônibus para a escola;

3) percepção dos pais de como o desenho urbano influencia sua decisão quanto a viagem a pé/bicicleta/ônibus do seu filho até a escola;

4) compreensão dos pais sobre o desenho urbano do bairro onde está localizada a escola; 
5) atitude dos pais quanto a viagem a pé/bicicleta/ônibus dos seus filhos até a escola; e

6) questões socioeconômicas da família.

Após o cálculo da amostra, um novo banco de dados foi preparado, e de posse dos endereços das escolas, as mesmas foram separadas por região administrativa. 0 sorteio das escolas a serem pesquisadas foi realizado no software Excel, com ajuda da função números aleatórios (ALEATORIOENTRE). O Anexo A-4 demonstra o nome das escolas pesquisadas, a região administrativa a qual pertence, o endereço, o número de formulários aplicados, bem como a rede a qual pertence (estadual, municipal ou particular). As escolas da rede federal não fizeram parte da pesquisa, por serem apenas 3 (três) do ensino fundamental em toda a cidade de Goiânia. O nome das escolas e sua localização em Goiânia está apresentado na figura 5.7.

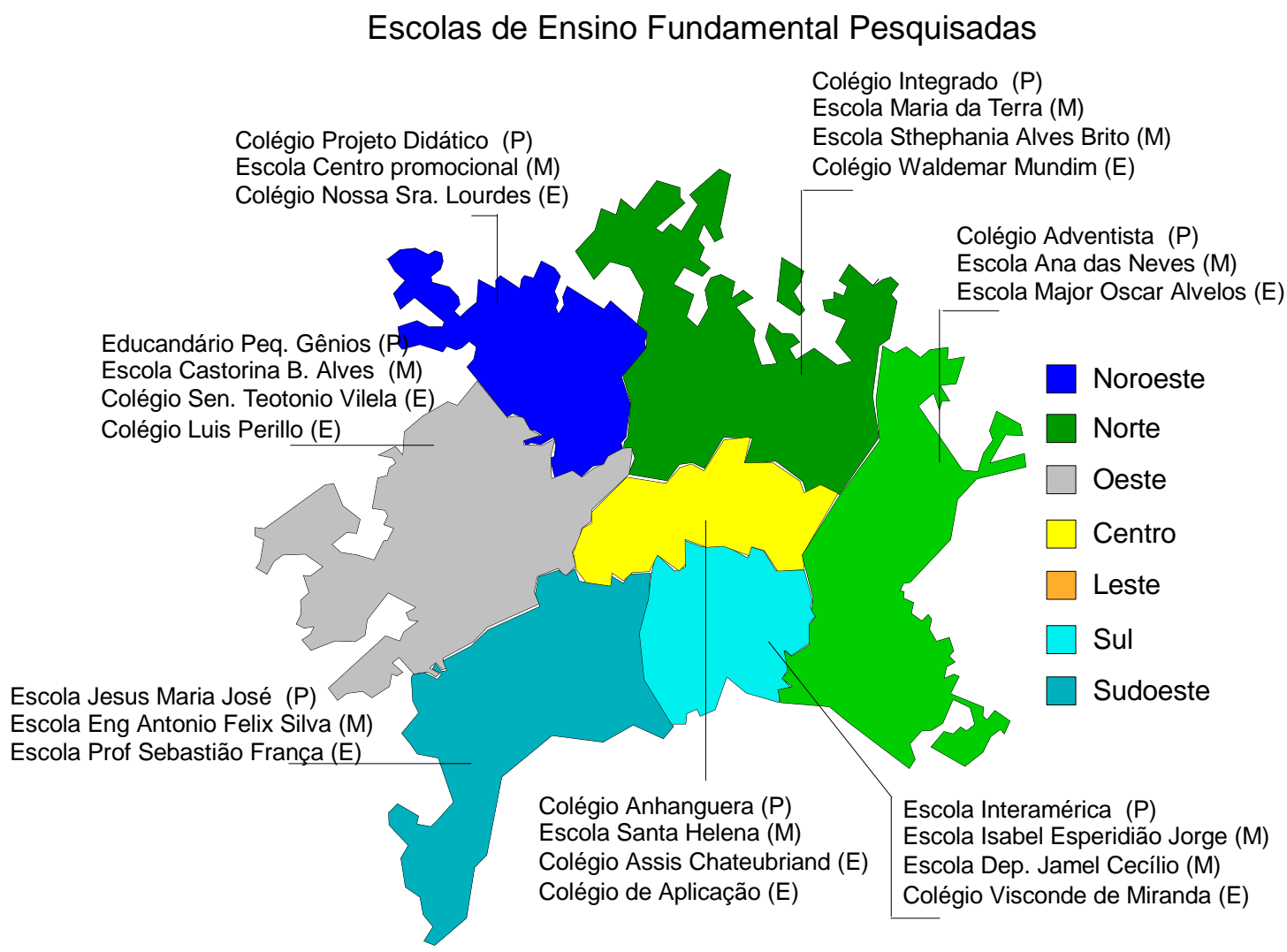

Figura 5.7 - Escolas Pesquisadas do Ensino Fundamental distribuídas nas sete Regiões Administrativas de Goiânia 


\subsection{DADOS COLETADOS COM OS PAIS}

Para a concepção do modelo comportamental, foi necessário, dois tipos de levantamento: 1 - aplicação de questionários com os pais dos alunos do ensino fundamental da cidade de Goiânia; 2 - levantamento in loco das variáveis da forma urbana dos bairros onde estão localizadas as escolas pesquisadas. Todas as variáveis levantadas serviram para abastecer o modelo do tipo logit multinomial utilizado e já descrito no capítulo 4 desta Tese.

A pesquisa de campo foi iniciada em agosto de 2015 e foram pesquisados os pais dos alunos do ensino fundamental (crianças com idade entre 6 e 14 anos de idade) das escolas evidenciadas na figura 5.7. O formulário de pesquisa consta no Anexo A-3. Inicialmente foram feitos contatos com as Secretarias Estadual e Municipal de Educação de Goiânia para autorização da pesquisa nas escolas. Os órgãos receberam o formulário e autorizaram a aplicação do mesmo, após uma explanação do estudo. A princípio foram realizadas visitas iniciais e reuniões com diretores e coordenadores das escolas para uma explicação sobre a pesquisa. Em uma visita posterior, os alunos e em uma terceira visita os pais das crianças.

As reuniões com os pais e alunos foram realizadas nas salas de aula, onde foi explicado todo o formulário, seu conteúdo e o objetivo da pesquisa. Os pais foram informados que no estudo, os mesmos não necessitavam serem identificados, nem seus endereços completamente informados (apenas o bairro). No formulário consta uma pequena introdução onde é explicado o motivo da pesquisa e seus objetivos. A criança foi a responsável pela devolução dos formulários respondidos, em uma data combinada, aos coordenadores da escola.

Inicialmente foram distribuídos 2.900 formulários, considerando um nível de confiança $95 \%$ e erro máximo 6\%, no entanto, o retorno dos mesmos ficaram abaixo da expectativa. O nível de confiança escolhido nesse estudo foi o de $95 \%$, já que é o mais adotado em vários estudos semelhantes, os erros máximos podiam variar em uma escala de 1 a 10\%, sem prejuízo algum para a confiança dos dados (Anexo A-1).

Em algumas escolas o retorno ficou aquém do esperado e outras escolas tiveram que ser sorteadas em um novo processo randômico. No anexo A-4 aparecem duas escolas visitadas na região Campinas Centro (estadual), região norte (municipal), região oeste (estadual) e região sudoeste (municipal). Com uma quantidade de 1.268 formulários 
corretamente preenchidos, optou-se por utilizar o nível de significância 95\% e erro máximo de $10 \%$, com um total requerido de 1.096 formulários

\subsection{DADOS COLETADOS VARIÁVEIS DA FORMA URBANA}

Para testar a influência da forma Urbana sobre a escolha do tipo de veículo nos deslocamentos escolares, foram levantadas variáveis do desenho urbano e já utilizadas em outros trabalhos como HANDY (1996a), CERVERO \& KOCKELMAN (1997), CERVERO et al. (2009), KRIZEK (2003), HANDY et al. (2006) e McMILLAN (2003), descritos no capitulo 2 desta Tese. Foram levantadas variáveis apenas dos bairros residenciais aonde se localizam as escolas e onde foram feitas as pesquisas com os pais e mostrados no Capítulo 6

Como em Handy (1996a) e Mcmillan (2003), neste trabalho optou-se em estudar como a forma urbana influencia a escolha do modo de transporte através das características do desenho das vias e do bairro, e mostradas na tabela 5.1. As variáveis do desenho urbano da cidade de Goiânia, foram levantadas através de visitas "in loco" e com ajuda de mapas digitais da cidade cedidos pela Secretaria Municipal de Desenvolvimento Econômico, Trabalho, Ciência e Tecnologia - Sedetec. As variáveis comprimento total das vias, número total de quadras, comprimento médio das quadras, número de interseções em cruz e em T e largura média das calçadas foram levantadas com ajuda do SIG e contadas todas as interseções dos bairros onde foi realizada a pesquisa com os pais, num total de 21 bairros. A calçada foi contabilizada como a medida da média entre as calçadas do setor estudado. O volume do tráfego veicular não foi contabilizado nesse estudo, devido ao esforço envolvido nas contagens de tráfego, como pesquisadores e tempo de pesquisa. Os dados referentes ao volume de veículos também não estão disponíveis no órgão de trânsito da prefeitura da cidade. Dessa forma, os dados de volume de tráfego veicular não foram utilizados, sem prejuízo à pesquisa. 
Tabela 5.6 - Forma de Coleta das Variáveis da Forma Urbana dos Bairros Pesquisados

\begin{tabular}{|c|c|c|}
\hline Variável da Forma Urbana & Conteúdo & Coleta \\
\hline Comprimento total das vias & Medida do comprimento total das vias do bairro & $\begin{array}{l}\text { Através mapa digital da cidade } \\
\text { de Goiânia }\end{array}$ \\
\hline Densidade de vias & $\frac{\text { Comprimento total das vias }(\mathrm{km})}{\text { área do setor }\left(\mathrm{km}^{2}\right)}$ & $\begin{array}{l}\text { Comp. das vias através mapa } \\
\text { digital. } \\
\text { Área do setor calculada } \\
\text { automaticamente pelo software. }\end{array}$ \\
\hline Número total de quadras & Número total de quadras do setor & $\begin{array}{l}\text { Através mapa digital da cidade } \\
\text { de Goiânia }\end{array}$ \\
\hline Densidade de quadras (km2) & $D_{q}=\frac{\text { Número total de quadras do setor }}{\text { área do setor }\left(\mathrm{km}^{2}\right)}$ & $\begin{array}{l}\text { Cálculo direto após coleta } \\
\text { anterior dos dados }\end{array}$ \\
\hline $\begin{array}{l}\text { Comprimento médio das } \\
\text { quadras }(\mathrm{km})\end{array}$ & Comprimento médio das quadras do setor & $\begin{array}{l}\text { Através mapa digital da cidade } \\
\text { de Goiânia }\end{array}$ \\
\hline $\begin{array}{l}\text { Número de interseções em cruz } \\
\text { Número de interseções em T }\end{array}$ & $\begin{array}{l}\text { Número total de interseções em formato cruz no } \\
\text { setor } \\
\text { Número total de interseções em formato T no } \\
\text { setor }\end{array}$ & Contadas no software Transcad \\
\hline Número total de interseções & $\begin{array}{l}\text { Soma do número de Interseções em cruz e T no } \\
\text { setor }\end{array}$ & Contadas no software Transcad \\
\hline Densidade de Interseções & 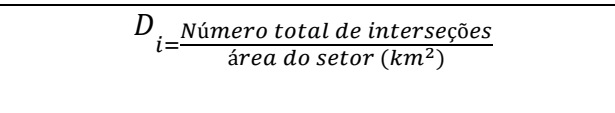 & $\begin{array}{l}\text { Cálculo direto após coleta } \\
\text { anterior dos dados }\end{array}$ \\
\hline Conectividade & $C=\frac{\text { Densidade de interseções }}{\text { número total de interseções }}$ & $\begin{array}{l}\text { Cálculo direto após coleta } \\
\text { anterior dos dados }\end{array}$ \\
\hline Largura média das calçadas & Referente a largura média das calçadas no setor & $\begin{array}{l}\text { Média da medida da largura das } \\
\text { calçadas do setor }\end{array}$ \\
\hline $\begin{array}{l}\text { Número de linhas do transporte } \\
\text { urbano que atendem o setor }\end{array}$ & $\begin{array}{l}\text { Quantidade de linhas de ônibus que percorrem o } \\
\text { setor }\end{array}$ & $\begin{array}{l}\text { Dado cedido pela Companhia } \\
\text { Metropolitana de Transportes } \\
\text { Coletivos - CMTC }\end{array}$ \\
\hline $\begin{array}{l}\text { Número de linhas do transporte } \\
\text { urbano que margeiam o setor }\end{array}$ & $\begin{array}{l}\text { Quantidade de linhas de ônibus que percorre as } \\
\text { principais avenidas do setor }\end{array}$ & $\begin{array}{l}\text { Dado cedido pela Companhia } \\
\text { Metropolitana de Transportes } \\
\text { Coletivos - CMTC }\end{array}$ \\
\hline $\begin{array}{l}\text { Quantidade total em } \mathrm{km} \text { de } \\
\text { ciclovias no setor }\end{array}$ & Quilometragem total de ciclovias & $\begin{array}{l}\text { Dado cedido Secretária } \\
\text { Municipal de Trânsito } \\
\text { Transportes e Mobilidade - SMT }\end{array}$ \\
\hline $\begin{array}{l}\text { Quantidade total em } \mathrm{km} \text { de } \\
\text { ciclofaixa no setor }\end{array}$ & Quilometragem total de ciclofaixas & $\begin{array}{l}\text { Dado cedido Secretária } \\
\text { Municipal de Trânsito } \\
\text { Transportes e Mobilidade - SMT }\end{array}$ \\
\hline $\begin{array}{l}\text { Quantidade total em } \mathrm{km} \text { de } \\
\text { ciclorota no setor }\end{array}$ & Quilometragem total de ciclorota & $\begin{array}{l}\text { Dado cedido Secretária } \\
\text { Municipal de Trânsito } \\
\text { Transportes e Mobilidade - SMT }\end{array}$ \\
\hline
\end{tabular}


Após levantamento de todas as variáveis, os cálculos necessários foram realizados em uma planilha com ajuda do software excel e são mostrados no Capítulo 6.

\subsection{O MODELO MULTINOMIAL PARA ESCOLHA DOS DIFERENTES MODOS}

O modelo utilizado nesta Tese foi do tipo Logit multinomial e já detalhado no Capítulo 4. Para construção do modelo deve-se montar as equações da função utilidade, proceder à validação do modelo, analisar as variáveis que apresentam influência positiva ou negativa na escolha dos indivíduos, avaliar a razão de chance (odds ratio) para as variáveis que apresentam uma significância satisfatória e, por último, analisar as probabilidades de escolha. Na figura 5.8 é apresentado um fluxo da sequência de construção do modelo desde a concepção das estatísticas de regressão até chegar nas probabilidades esperadas.

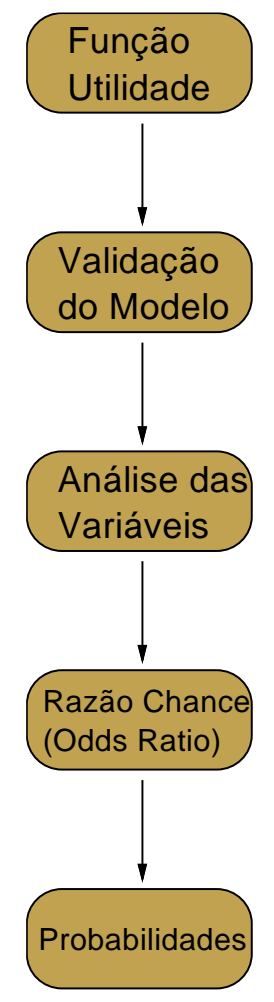

Figura 5.8 - Fluxograma de Análise do Modelo Estatístico

Para montagem das equações da função utilidade fez-se o processamento do modelo estatístico no software R-Studio $\AA$. As variáveis que abasteceram o modelo de regressão logísticas, foram retiradas do formulário de pesquisa e estão organizadas no anexo B2. Foram excluídas as variáveis que apresentam pouca significância ao problema estudado objetivando diminuir o esforço computacional e suprimir os resultados considerados espúrios (como as variáveis relacionadas às ciclovias, ciclofaixa e ciclorota). As variáveis que normalmente são excluídas correspondem àquelas que tiveram nenhuma ou pouca porcentagem de respondentes. Trabalhou-se no 
processamento completo com a resposta prevendo a interação de todas as variáveis com significância e, posteriormente, procedeu-se o processamento de cada variável independente com o intuito de observar, principalmente, as variáveis relacionadas com a forma urbana e a influência na escolha dos indivíduos pelos modos mais sustentáveis. Na tabela 5.7 apresentamse os resultados do processamento do modelo completo envolvendo todas as variáveis identificadas com significância no modelo (essa tabela também é melhor explicada no Capítulo 6). A significância foi observada avaliando os valores de probabilidades $\operatorname{Pr}(>|z|)$, também

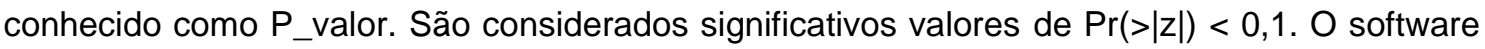
R-Studioß identifica com um asterisco os valores que atendem a esta relação.

Tabela 5.7 - Resultados do Processamento Completo - R-Studio $\circledast$

\begin{tabular}{|c|c|c|c|c|c|}
\hline \multirow[b]{2}{*}{$($ Intercept) $: 1$} & \multirow{2}{*}{$\begin{array}{r}\text { Estimate } \\
8.24614\end{array}$} & \multicolumn{4}{|c|}{ Std. Error z-value $\operatorname{Pr}(>|z|)$} \\
\hline & & 1.50871 & 5.466 & $4.61 e-08$ & 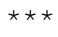 \\
\hline (Intercept) $: 2$ & 11.07325 & 1.48722 & 7.446 & $9.65 e-14$ & $\star \star \star$ \\
\hline (Intercept) $: 3$ & 6.97143 & 2.17163 & 3.210 & 0.001326 & $\star \star$ \\
\hline V3Municipal:1 & -0.43980 & 0.42455 & -1.036 & 0.300239 & \\
\hline V3Municipal:2 & -0.87742 & 0.39850 & -2.202 & 0.027677 & * \\
\hline V3Municipal:3 & 0.06779 & 0.65728 & 0.103 & 0.917857 & \\
\hline V3Particular: 1 & 2.35639 & 0.51168 & 4.605 & $4.12 e-06$ & $\star \star \star$ \\
\hline V3Particular:2 & 0.11455 & 0.51557 & 0.222 & 0.824174 & \\
\hline V3Particular:3 & -0.96611 & 1.18346 & -0.816 & 0.414301 & \\
\hline V180 aluno vai sozinho: 1 & -4.49721 & 0.59155 & -7.602 & $2.91 e-14$ & $\star \star \star$ \\
\hline V180 aluno vai sozinho:2 & -2.93664 & 0.58140 & -5.051 & $4.40 e-07$ & $\star \star \star$ \\
\hline V180 aluno vai sozinho: 3 & -2.69768 & 0.71013 & -3.799 & 0.000145 & $\star \star \star *$ \\
\hline V18Pai:1 & 0.41732 & 0.90384 & 0.462 & 0.644284 & \\
\hline V18Pai:2 & -0.99134 & 0.92655 & -1.070 & 0.284652 & \\
\hline V18Pai:3 & -2.00785 & 1.39215 & -1.442 & 0.149228 & \\
\hline V18Um outro adulto da família: 1 & -1.10884 & 0.73027 & -1.518 & 0.128913 & \\
\hline V18Um outro adulto da família:2 & -1.61878 & 0.74888 & -2.162 & 0.030648 & * \\
\hline V18Um outro adulto da família:3 & -1.93905 & 0.98879 & -1.961 & 0.049876 & * \\
\hline V18Um outro adulto que não é da família:1 & -1.19947 & 0.70584 & -1.699 & 0.089252 & · \\
\hline V18Um outro adulto que não é da família:2 & -3.13519 & 0.77274 & -4.057 & $4.97 e-05$ & $\star \star \star$ \\
\hline V18Um outro adulto que não é da família:3 & -16.78393 & 576.65607 & -0.029 & 0.976780 & \\
\hline V18Vizinhos: 1 & -2.97845 & 0.77488 & -3.844 & 0.000121 & $\star \star \star$ \\
\hline V18Vizinhos:2 & -1.88058 & 0.76513 & -2.458 & 0.013977 & * \\
\hline V18Vizinhos: 3 & -2.51332 & 1.27678 & -1.968 & 0.049013 & * \\
\hline V47sim: 1 & -0.10084 & 0.34493 & -0.292 & 0.770030 & \\
\hline V47sim: 2 & -1.77261 & 0.34193 & -5.184 & $2.17 e-07$ & $\star \star \star$ \\
\hline V47sim: 3 & -0.98730 & 0.56804 & -1.738 & 0.082197 & . \\
\hline V55sim: 1 & -0.85760 & 0.31281 & -2.742 & 0.006113 & $\star \star$ \\
\hline V55sim: 2 & -0.84831 & 0.30119 & -2.817 & 0.004855 & $\star \star$ \\
\hline V55sim:3 & -0.62088 & 0.49883 & -1.245 & 0.213253 & \\
\hline V91Muito importante: 1 & -0.29140 & 0.37746 & -0.772 & 0.440114 & \\
\hline V91Muito importante: 2 & -0.10873 & 0.36602 & -0.297 & 0.766428 & \\
\hline V91Muito importante: 3 & -1.12967 & 0.58641 & -1.926 & 0.054052 & · \\
\hline V91Não é importante: 1 & 1.56100 & 0.51885 & 3.009 & 0.002625 & $\star \star$ \\
\hline V91Não é importante: 2 & 2.12097 & 0.49952 & 4.246 & $2.18 e-05$ & $\star \star \star$ \\
\hline V91Não é importante: 3 & 0.75417 & 0.71449 & 1.056 & 0.291176 & \\
\hline V91Pouco importante: 1 & 2.16347 & 0.71378 & 3.031 & 0.002438 & $\star \star$ \\
\hline V91Pouco importante: 2 & 2.52486 & 0.69821 & 3.616 & 0.000299 & $\star \star \star$ \\
\hline V91Pouco importante:3 & 0.86751 & 1.02791 & 0.844 & 0.398696 & \\
\hline V100Muito importante: 1 & -0.86328 & 0.47245 & -1.827 & 0.067665 & . \\
\hline V100Muito importante: 2 & -0.58182 & 0.46022 & -1.264 & 0.206157 & \\
\hline V100Muito importante:3 & 0.22234 & 0.67168 & 0.331 & 0.740635 & \\
\hline V100Não é importante:1 & -2.02250 & 0.49756 & -4.065 & $4.81 e-05$ & $\star \star \star$ \\
\hline V100Não é importante:2 & -2.18988 & 0.48918 & -4.477 & $7.58 e-06$ & $\star \star \star$ \\
\hline V100Não é importante:3 & -1.40168 & 0.76116 & -1.842 & 0.065548 & · \\
\hline V100Pouco importante: 1 & -1.62564 & 0.51430 & -3.161 & 0.001573 & $\star \star$ \\
\hline V100Pouco importante: 2 & -1.69444 & 0.50178 & -3.377 & 0.000733 & $\star \star \star$ \\
\hline V100Pouco importante: 3 & -1.49173 & 0.84915 & -1.757 & 0.078964 & . \\
\hline $\mathrm{V} 110: 1$ & -0.17666 & 0.05201 & -3.397 & 0.000682 & $\star \star \star$ \\
\hline V110:2 & -0.28262 & 0.05113 & -5.528 & $3.24 e-08$ & $\star \star \star$ \\
\hline V110:3 & -0.24131 & 0.08334 & -2.896 & 0.003785 & $\star \star$ \\
\hline V121:1 & 0.07135 & 0.05803 & 1.230 & 0.218870 & \\
\hline V121:2 & 0.10169 & 0.05704 & 1.783 & 0.074626 & . \\
\hline V121: 3 & 0.18795 & 0.07558 & 2.487 & 0.012887 & $\star$ \\
\hline
\end{tabular}


$\mathrm{Na}$ obtenção da resposta pelo processamento completo identificou-se na primeira coluna os modais de comparação (1- modo outros; 2 - modo a pé; 3 - modo bicicleta) e fixou-se um quarto modal (4 - modo ônibus) como referência na análise.

O modo de referência é escolhido de acordo com os objetivos da análise. Para cada modo, 1, 2 e 3 são identificados no modelo os interceptos da função resposta em relação ao quarto modal referenciado. Na primeira coluna da tabela 5.7 identificam-se também as variáveis onde se obteve maior significância durante o processamento completo.

Na segunda coluna da tabela 5.7 são organizados os estimadores ("estimate") de cada intercepto e das variáveis com resultados significativos. Na terceira coluna são listados os desvios padrões (“Std. Error”) que serão utilizados para mensurar a variabilidade da resposta. Na quarta coluna apresentam-se os testes de significância ("z-value") também conhecidos na literatura específica como $Z$ _valor. O teste apresentado é baseado na estatística de Wald já descrita no quarto capítulo. Na quinta coluna identificam-se as probabilidades da função resposta onde destacam-se com um asterisco as mais significativas $(\operatorname{Pr}(>|z|)<0,1)$.

\subsubsection{Cálculo das Utilidades e Probabilidades da Função Resposta}

Com base na resposta do processamento do modelo completo é possível montar a equação que representa a função utilidade para o modo caminhamento. A função segue o formato da equação 4.1, destacando-se a constante ("intercepto") e os estimadores ("pesos") para cada variável com significância. A função utilidade para o modo caminhamento e resultante do processamento do modelo completo está descrita na equação 6.2 e a função probabilidade de cada modo está apresentada na equação 6.3. 


$$
\begin{aligned}
& F_{\text {Apé }}=11,07325-0,87742 \cdot V 3_{\text {Municipal }}+0,11455 \cdot \text { V3Particular } \\
& -2,93664 . V 18_{\text {Alunovaisozinho }}-0,99134 . V 18_{\text {pai }} \\
& \text { - 1,61878. V18adultodafamilia } \\
& \text { - 3,13519. V18adultonãodafamília } \\
& \text { - 1,88058.V18vizinhos - 1,77261.V47 } \\
& \text { - 0.84831.V55-0,10873.V91muitoimportante } \\
& \text { +2,12097.V91nãoéimportante } \\
& +2,52486 . \text { V91poucoimportante } \\
& \text {-0,58182.V100muitoimportante } \\
& \text { - 2,18988.V100nãoéimportante } \\
& \text { - 1,69444.V100poucoimportante } \\
& -0,28262 \cdot V 110+0,10169 \cdot V 121
\end{aligned}
$$

No anexo C são anotadas as probabilidades obtidas através do processamento do modelo completo estimando os possíveis modos escolhidos pelos indivíduos na condução das crianças até a escola. Considerando os modos estimados como $A, B, C$ e $D$ sendo $A$ = a pé; $B$ = bicicleta; $C$ = ônibus e $D=$ outros, a probabilidade calculada para a escolha de cada modo é dada por:

$$
\begin{gathered}
\operatorname{Prob}(A)=\frac{e^{U a}}{e^{U a}+e^{U b}+e^{U c}+e^{U d}} \\
\operatorname{Prob}(B)=\frac{e^{U b}}{e^{U a}+e^{U b}+e^{U c}+e^{U d}} \\
\operatorname{Prob}(C)=\frac{e^{U c}}{e^{U a}+e^{U b}+e^{U c}+e^{U d}} \\
\operatorname{Prob}(D)=\frac{e^{U d}}{e^{U a}+e^{U b}+e^{U c}+e^{U d}}
\end{gathered}
$$

Onde $\operatorname{Prob}(A)+\operatorname{Prob}(B)+\operatorname{Prob}(C)+\operatorname{Prob}(D)=1,0$

\section{Sendo :}

\footnotetext{
$\mathrm{Ua}=\mathrm{a}+\mathrm{b} 1 \cdot \mathrm{X} 1 \mathrm{a}+\ldots+\mathrm{bn} \cdot \mathrm{Xna}$

$\mathrm{Ub}=\mathrm{b}+\mathrm{b} 1 \cdot \mathrm{X} 1 \mathrm{~b}+\ldots+\mathrm{bn} \cdot \mathrm{Xnb}$

$\mathrm{Uc}=\mathrm{c}+\mathrm{b} 1 \cdot \mathrm{X} 1 \mathrm{c}+\ldots+\mathrm{bn} \cdot \mathrm{Xnc}$

$U d=d+b 1 . X 1 d+\ldots+b n . X n d$

Xna, Xnb, Xnc e Xnd
}

Ua, utilidade associada ao modo $A$ (a pé) $\mathrm{Ub}$, utilidade associada ao modo $\mathrm{B}$ (bicicleta) Uc, utilidade associada ao modo C (ônibus) Ud, utilidade associada ao modo $D$ (outros) São os atributos levados em consideração na análise dos modos 


\subsection{TÓPICOS CONCLUSIVOS}

Neste capítulo percebe-se a metodologia utilizada de forma a explorar os dados que envolvem as características comportamentais das famílias além de aspectos de forma urbana. As variáveis tomadas no presente trabalho totalizam um número de 123 e foram utilizadas na montagem da função utilidade que constitui a base para a entrada de dados do software Rstudio (identificadas no Anexo B2). Numa primeira etapa denominada "validação", selecionou-se as variáveis que apresentam significância ao problema em estudo e exclui-se as demais, melhorando assim a precisão das respostas e o esforço computacional. Na função utilidade identificam-se os pesos para cada variável com significância ao problema em estudo. Os pesos calculados são utilizados na avaliação da razão de chance ("odds ratio") de um usuário utilizar um determinado modal além da probabilidade de escolha dos mesmos. 
Resultados

Obtidos 


\subsection{RESULTADOS OBTIDOS}

Nesta etapa procedeu-se a modelagem estatística com base nos dados obtidos com a pesquisa com os pais e levantamento dos dados da forma urbana dos bairros pesquisados.

Para conclusão final dos resultados a sequência das análises foi:

1 - Dados coletados na pesquisa com os pais - apresenta a análise descritiva dos dados coletados com a aplicação do questionário com os pais dos alunos e evidencia a percepção dos mesmos sobre as variáveis estudadas e citadas no capítulo 5 desta Tese.

2 - Dados coletados variáveis da forma urbana - o ítem apresenta todas as variáveis da forma urbana, levantadas in loco e com ajuda de mapas georeferenciados da cidade de Goiânia, dos bairros onde estão localizadas as escolas pesquisadas.

3 - Escolha da influência da forma urbana sobre a escolha modal realizada para apresentar que variáveis são determinantes na escolha por um modo tendo como base os questionários e as variáveis da forma urbana levantadas. Utilizou-se um modelo multinomial construído para o problema proposto e por ser aquele que apresenta a melhor descrição das escolhas dos indivíduos (sendo, por isso, o mais usado na literatura) entre alternativas e opções, por meio das especificações das funções utilidade.

\subsection{RESULTADO DA PESQUISA COM OS PAIS}

\section{- Modo de Deslocamento até a Escola}

No que se refere aos modos de transporte utilizados pelos indivíduos na condução das crianças até a escola, a presente Tese os dividiu em 4 modos representados pelo caminhamento (a pé), a bicicleta, o ônibus e outros meios de transporte (motos, carros e vans). Esta divisão foi definida na tentativa de distinguir os modais mais sustentáveis dos demais. 


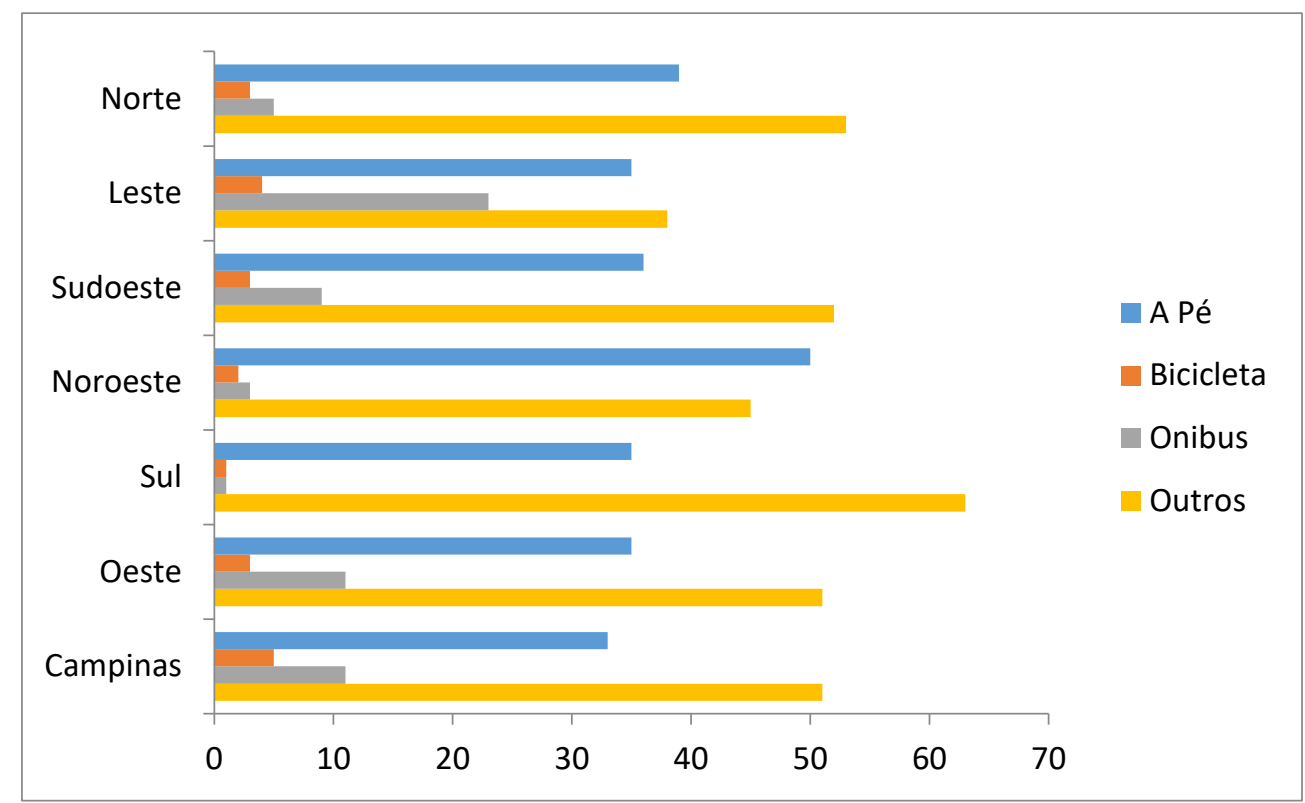

Figura 6.1 - Modo de transporte/região das famílias pesquisadas

Na figura 6.1 percebe-se que a condução de crianças através de outros meios de transporte (motos, carros e vans) tem predominância em quase todas as regiões administrativas de Goiânia com exceção da região Noroeste onde prevalece o modo caminhamento ("a pé"). Na região sul destaca-se a alta porcentagem de utilização de carros o que pode ser explicado pelo fato que nesta região administrativa se concentra a maior faixa de renda dos moradores de Goiânia. Dentre os modais estudados, a bicicleta é que apresentou as menores porcentagens de preferência entre os indivíduos pesquisados para todas as regiões administrativas de Goiânia. A utilização do transporte coletivo como preferência dos indivíduos na condução de crianças até a escola obteve uma porcentagem maior nas regiões leste (23\%), campinas (11\%) e oeste $(11 \%)$ pelo fato de que nestas regiões se concentram o maior número de linhas de transporte público disponíveis (Anexo A-2). Nas demais regiões pesquisadas, a escassez de linhas pode explicar a baixa preferência dos indivíduos por este modo de transporte.

Na figura 6.2 é classificado o modo de transporte por rede de ensino. Pode-se observar no gráfico que a maior parte dos estudantes que utilizam o modo a pé, bicicleta e ônibus estão nas escolas estaduais e municipais. $46 \%$ dos estudantes das escolas estaduais e $51,5 \%$ dos alunos das escolas municipais se deslocam a pé. Entre os alunos das escolas particulares $82 \%$ se deslocam pelo modo outros (carro individual, moto ou van). Ainda sobre o modo outros, é importante ressaltar que $36 \%$ dos alunos das escolas municipais e $25 \%$ dos estudantes das escolas estaduais se deslocam por esse modo. 


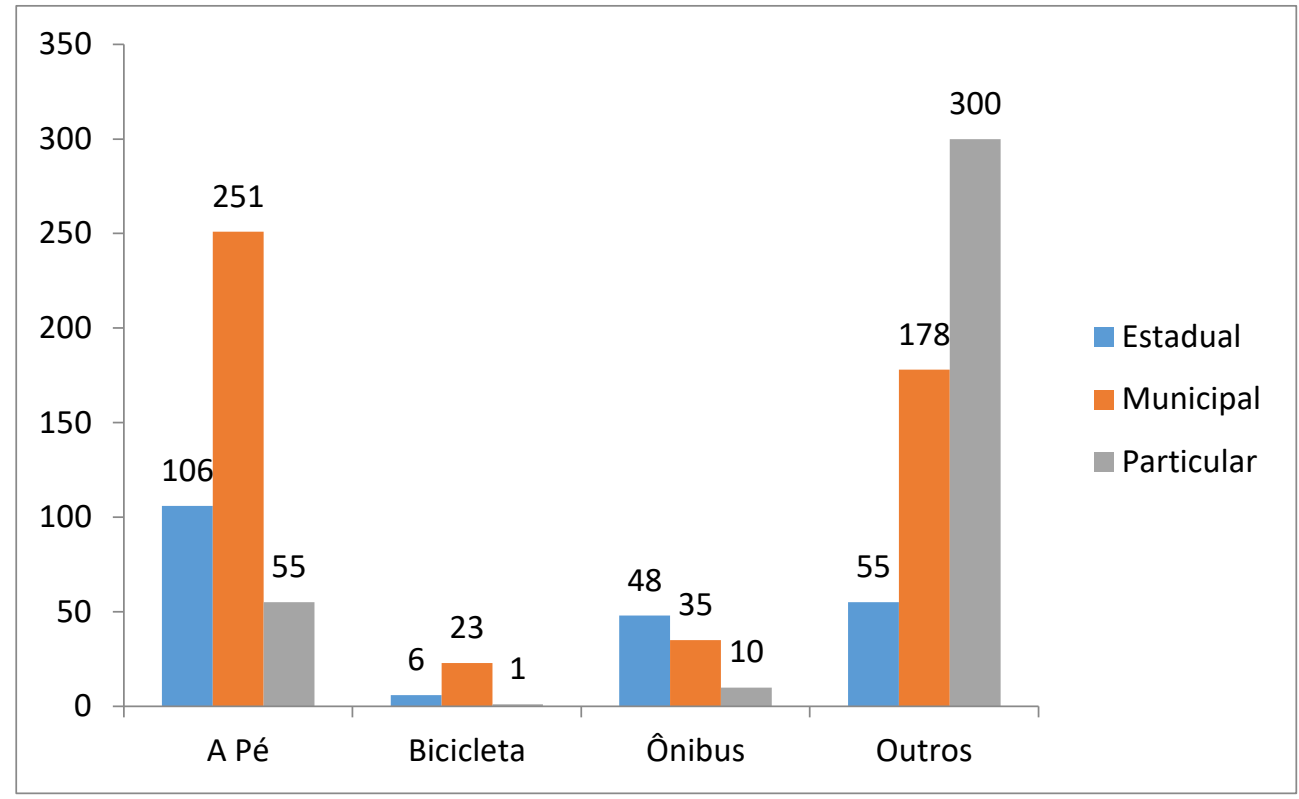

Figura 6.2 - Modo de transporte/rede das famílias pesquisadas

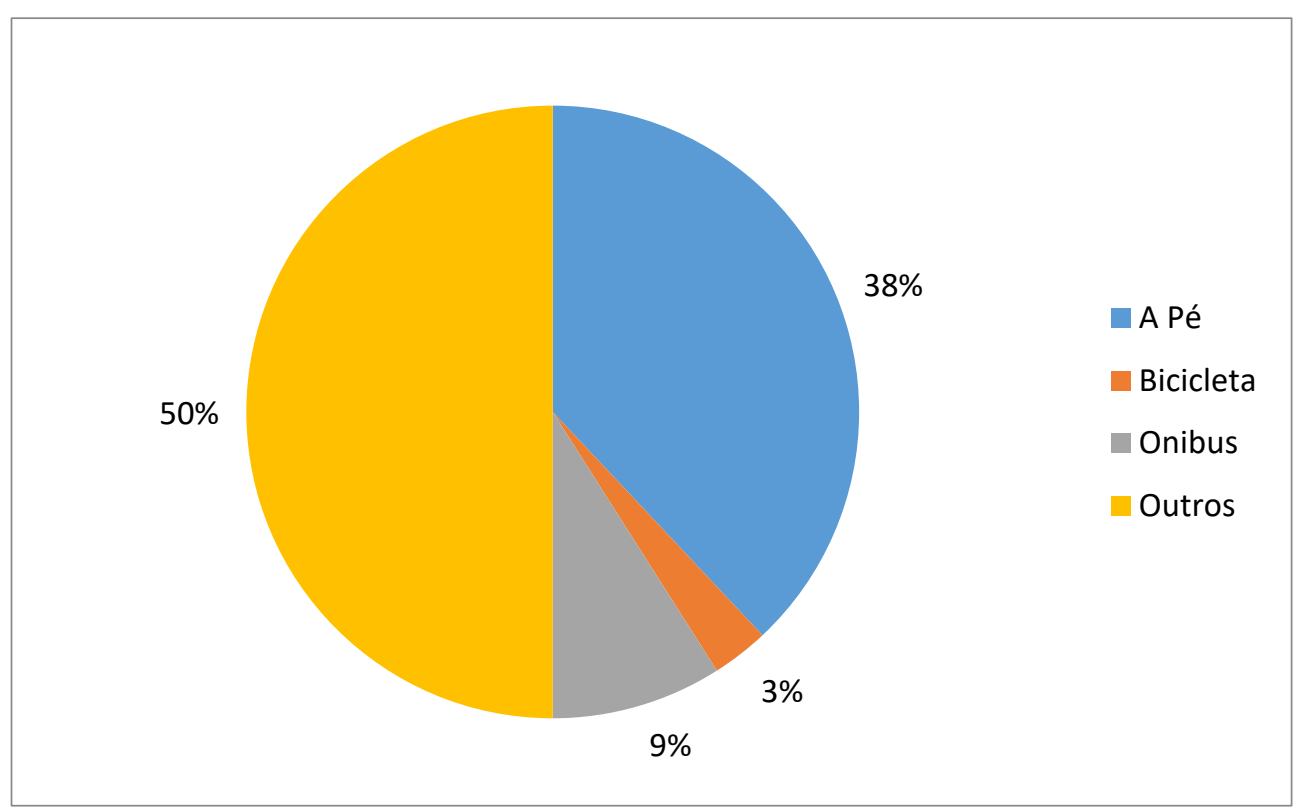

Figura 6.3 - Modo de transporte na cidade de Goiânia das famílias pesquisadas

Considerando toda cidade de Goiânia, a utilização de outros meios de transporte (50\%) representado por motos, carros e vans de transporte escolar prevalece sobre as outras opções na escolha para condução das crianças até a escola, representando metade da preferência em relação aos demais modos de transporte. Destacam-se as baixas porcentagens encontradas para utilização do transporte coletivo e a bicicleta. O modo caminhamento como preferência na escolha para condução de crianças obteve uma porcentagem de $38 \%$ em relação aos demais modos. 
- Renda das Famílias

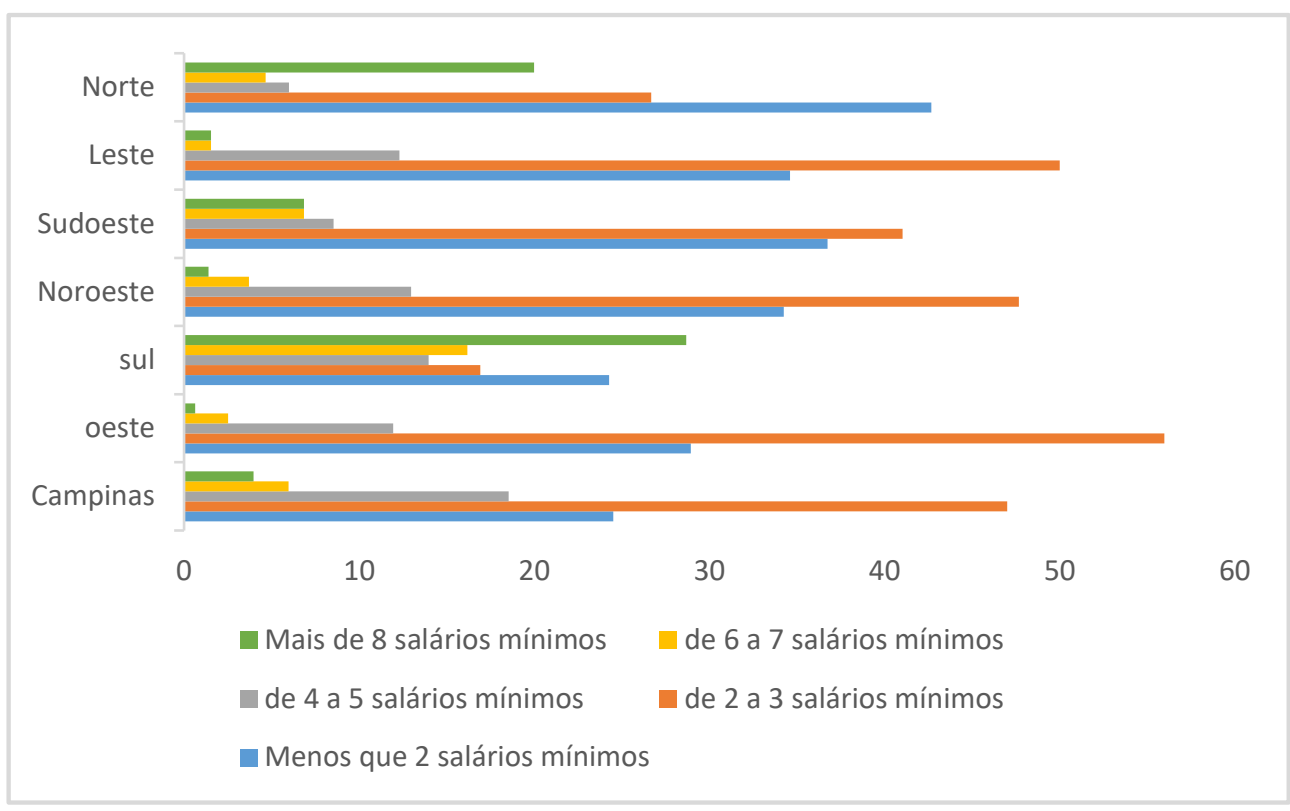

Figura 6.4 - Renda/região das famílias pesquisadas

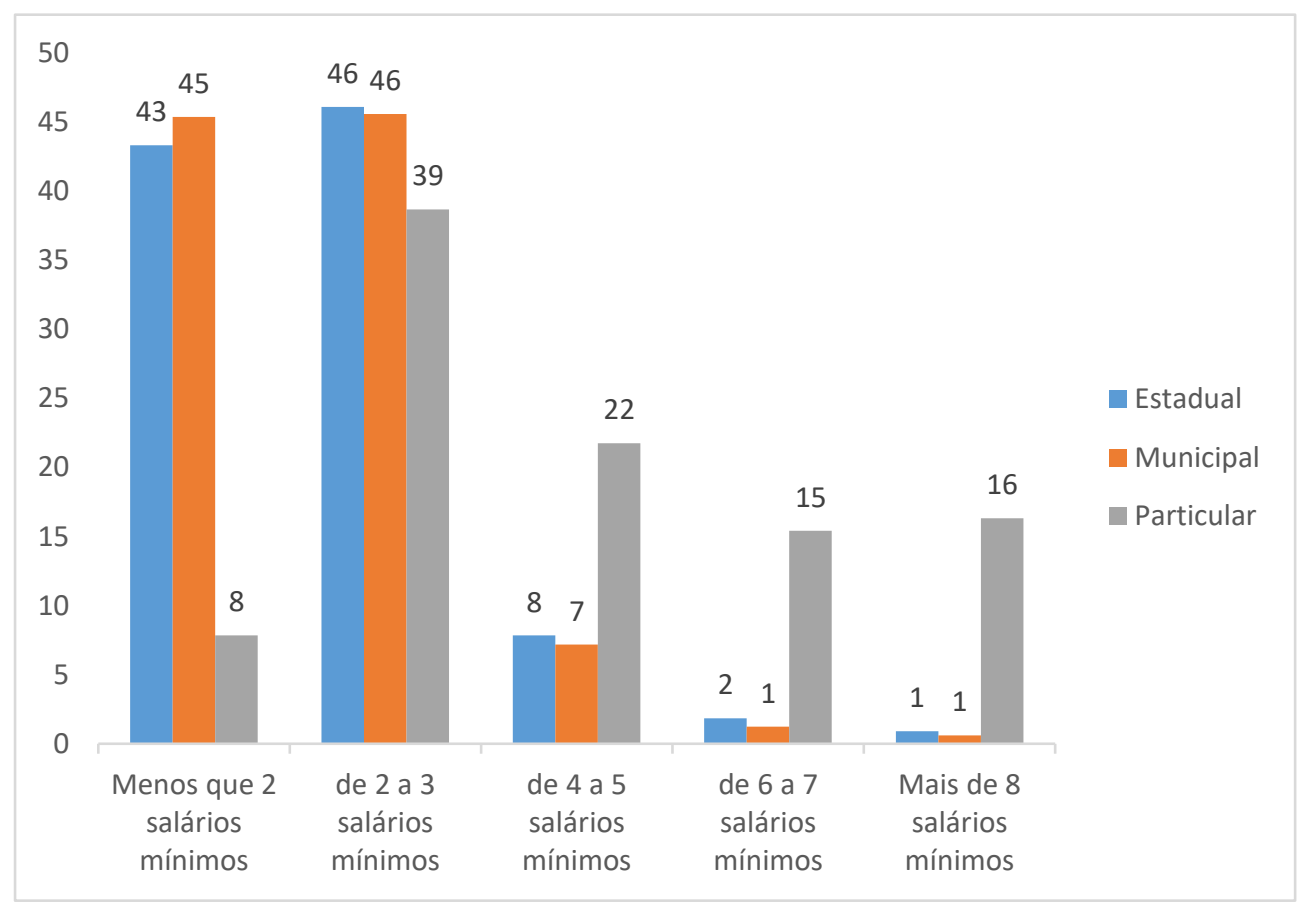

Figura 6.5 - Renda/rede das famílias pesquisadas 


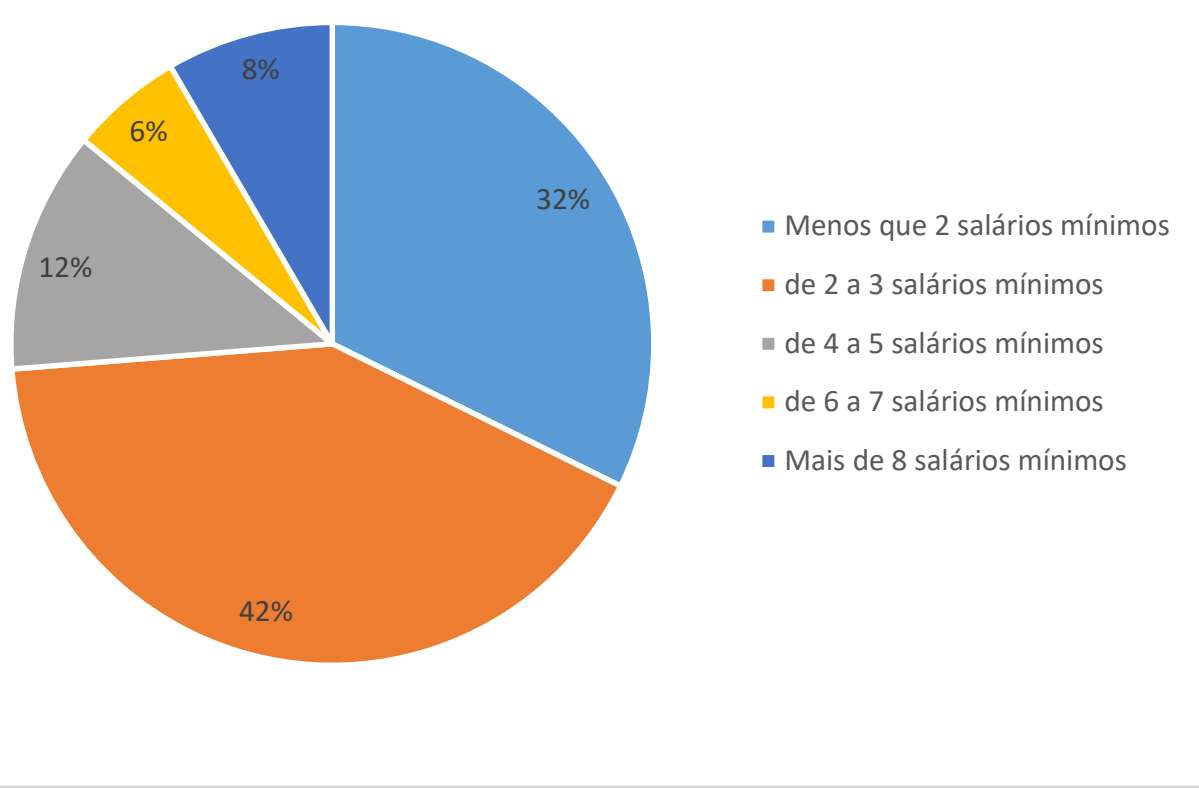

Figura 6.6 - Renda na cidade de Goiânia das famílias pesquisadas

Pode-se compreender melhor o processo da expansão urbana de Goiânia, o crescimento populacional e as características socioeconômicas a partir da história da cidade. Em 1947 a mancha urbana de Goiânia compreendia Campinas e o Setor Central, abrangendo também os Setores Sul, Oeste e Norte (Bairro Popular). Nesse ano existiam algumas ocupações às margens dos córregos Botafogo e Areião, que deram origem aos bairros Vila Nova e Nova Vila, e extrapolavam os limites do desenho original da cidade. (Ribeiro, 2004)

Entre as décadas de 1950 e 1960, ao contrário do que aconteceu na década anterior, houve uma explosão no número de bairros. Vários fatores contribuíram para tal fenômeno dentre eles: a liberação do processo de parcelamento à iniciativa privada, a revogação da obrigatoriedade de implantação de infraestrutura urbana mínima para a instalação dos loteamentos e a inexistência de um plano diretor que regulasse o crescimento da cidade (RIBEIRO, 2004). Os habitantes eram principalmente imigrantes oriundos de Minas Gerais, mas também das regiões Norte e Nordeste do Brasil.

Nesse período regiões como a Norte, Leste, Sudoeste e oeste foram intensamente loteadas e habitadas, com falta de articulação entre um loteamento e outro. Nesta perspectiva, o aumento de loteamentos em Goiânia gerou espaços segregados, haja vista a ausência de infraestrutura urbana, a carência de seus moradores e a distância e dificuldades de acesso ao centro da cidade. Observa-se no gráfico 5.10 que a renda 
informada na pesquisa das regiões Leste, Campinas, Sudoeste, Noroeste e Oeste de 2 salários mínimos, pode ser herança dessa história da cidade.

Observando ainda o gráfico 6.4, chama atenção a renda informada pelos habitantes da região Sul - oito salários mínimos e que se diferencia das demais regiões. Faz-se oportuno, dessa forma, buscar na história da cidade esclarecimento para tal fenômeno.

Segundo MORAES (1991) foi na direção sul que prevaleceu a concentração da população de maior poder aquisitivo, além da instalação nesta Região de empreendimentos, serviços públicos e privados.

“... A expansão da cidade, a partir do plano piloto original, se deu predominantemente ao Sul. Esta tendência começou a tomar corpo e no período seguinte, de 1964 a 1975, se intensificou, para atingir sua expressão máxima no período de 1975 a 1985"

A Região Sul é caracterizada pelo adensamento de construções tanto verticais quanto horizontais, essas marcadas por casas luxuosas, como cita VAZ (2002). A atividade comercial é voltada para as camadas de média e alta renda. CHAVEIRO (2001), descreve que setores como Oeste, Sul, Bueno, Jardim Bela Vista, e uma pequena faixa do Jardim América, constituem o subcentro de renda alta como é o setor Bueno no limítrofe com o Nova Suíça e o Bela Vista.

Segundo MARINHO (2006) "a Região Sul, ao longo da produção do espaço urbano de Goiânia, sofreu intensa ocupação populacional e atraiu a instalação de atividades econômicas. Isso favoreceu a implantação de infraestrutura e os investimentos da construção civil no seu espaço, a partir da década de 1970. A estruturação e a verticalização da Região acabaram por promover a valorização dos terrenos aí localizados e, consequentemente, reforçaram sua posição de lugar "nobre" no imaginário do "goianiense."

Em sua história mais recente a região Noroeste iniciou seu processo de ocupação em 1979 com a invasão da Fazenda Caveiras, em três etapas. A primeira, deu origem ao bairro Jardim Nova Esperança, e pode-se dizer que a ocupação da região noroeste foi marcada por lutas sociais em busca do direito de morar. Atualmente é composta por bairros como Vila Finsocial, Vila Mutirão I, II e III, e Jardim Curitiba, já consolidados. Em suma a população que inicialmente habitou essa região eram os pobres e excluídos, e 
que até os dias atuais figura como uma região carente de políticas públicas. MOYSÉS (2004)

A produção de espaços valorizados segregados nas metrópoles é questão de estudo nas mais variadas disciplinas do planejamento urbano, e essa valorização do espaço urbano é ocasionada pela sua localização na cidade. A desigualdade sócioespacial pode ser observada na paisagem urbana na maior parte das metrópoles brasileira e em Goiânia, esse feito não é diferente, bastando comparar a cidade de norte-sul.

Quanto a renda dividida por rede de ensino os maiores salários estão concentrados nas escolas particulares onde $60 \%$ dos pais ganham entre 2 a 5 salários mínimo. Na rede municipal $89 \%$ recebem de 1 a 3 salários e a estadual $91 \%$. Considerando a renda na cidade de Goiânia entre os pais de alunos que cursam o ensino fundamental $74 \%$ ganham de 1 a 3 salários mínimos, $12 \%$ de 4 a 5 e apenas $6 \%$ de 6 a 7 salários.

- Número de Veículos no Domicílio

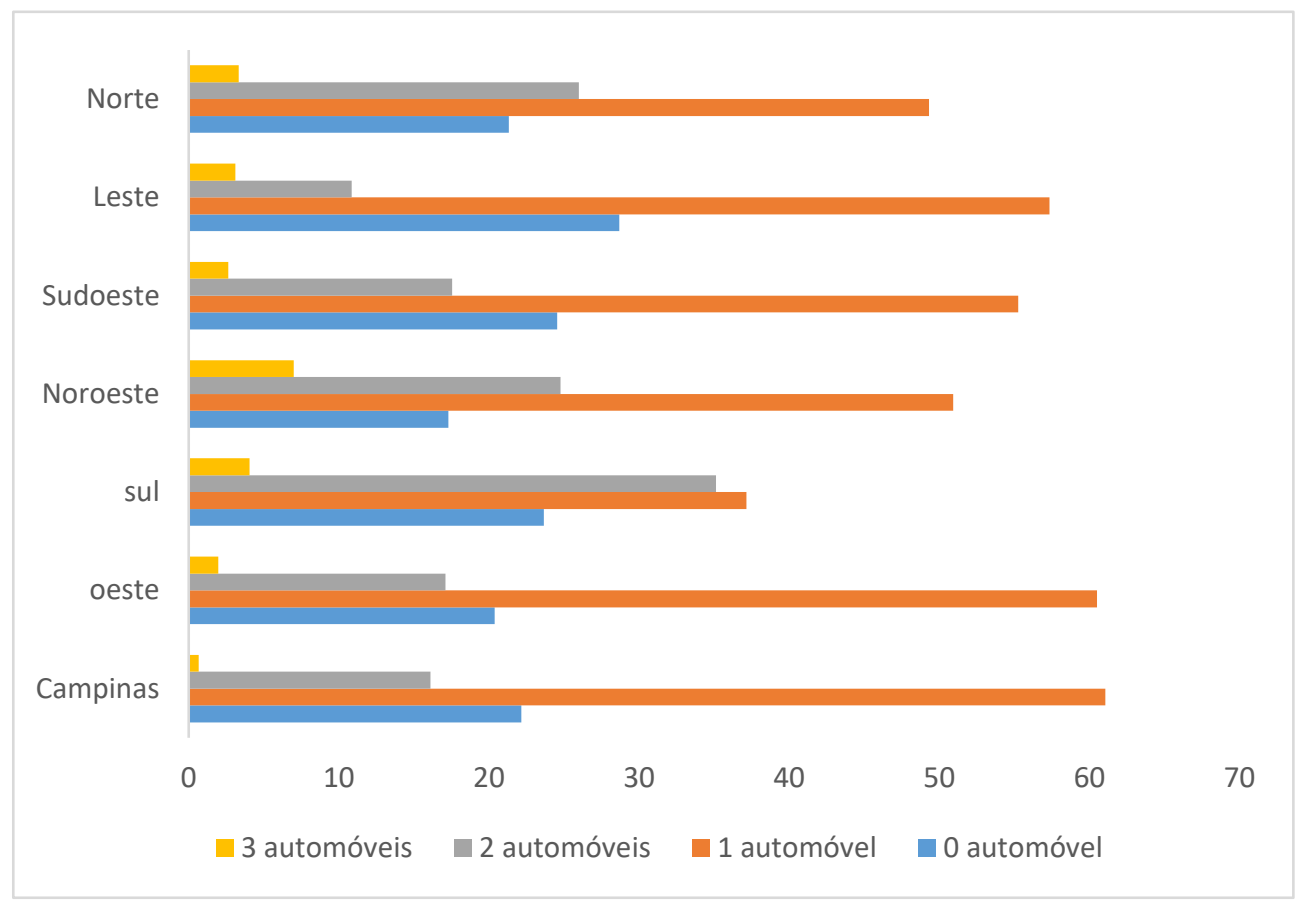

Figura 6.7 - Número de veículos/região das famílias pesquisadas

Quanto ao número de veículos por região, pode-se observar que grande parte das famílias tem pelo menos 1 veículo. A região Sul se sobressai dentre as demais, pois $35 \%$ das famílias dessa região afirmam possuir pelo menos 2 veículos, quase a mesma quantidade de famílias que possuem 1 veículo (37\%), no entanto esta região, como mostrado anteriormente se destacou também como a maior renda entre as famílias. 


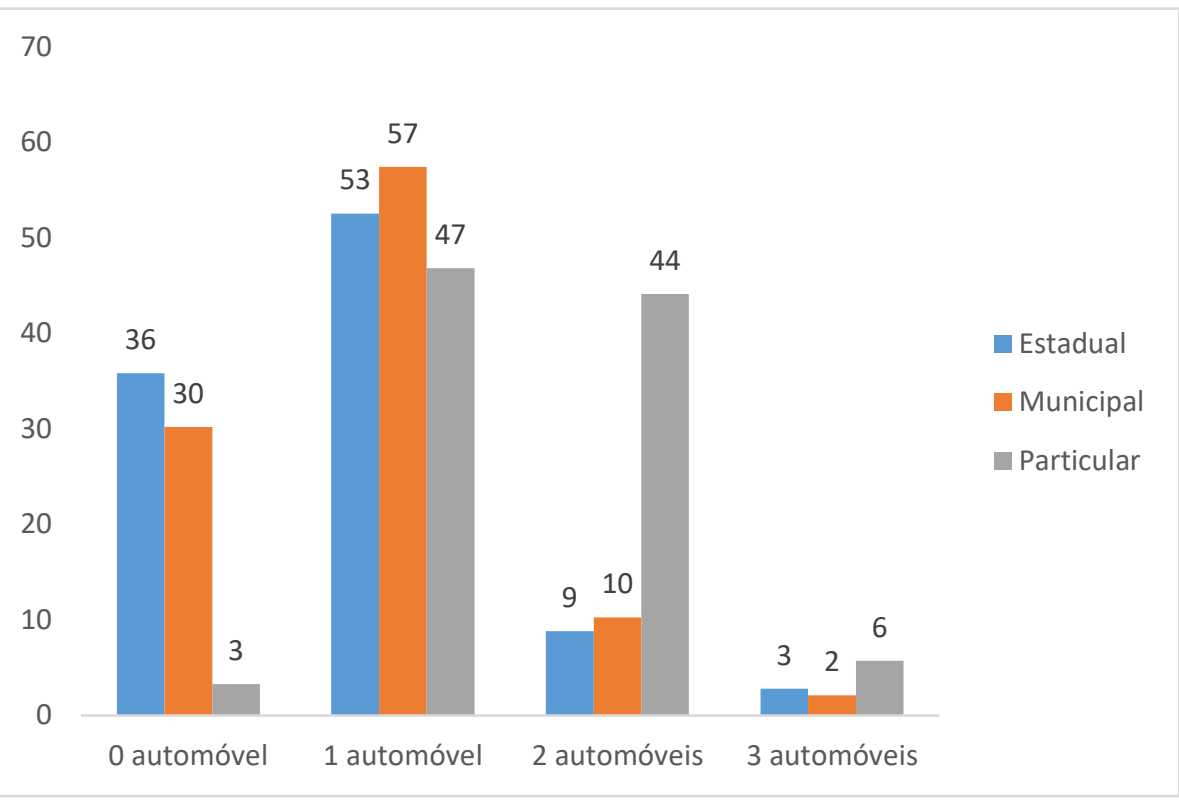

Figura 6.8 - Número de veículos/rede das famílias pesquisadas

Observa-se na figura 6.8 que mais da metade das famílias das redes estaduais e municipais, $53 \%$ e 57\%, respectivamente, possuem pelo menos 1 veículo e que apenas $3 \%$ das famílias da rede particular não possuem nenhum veículo.

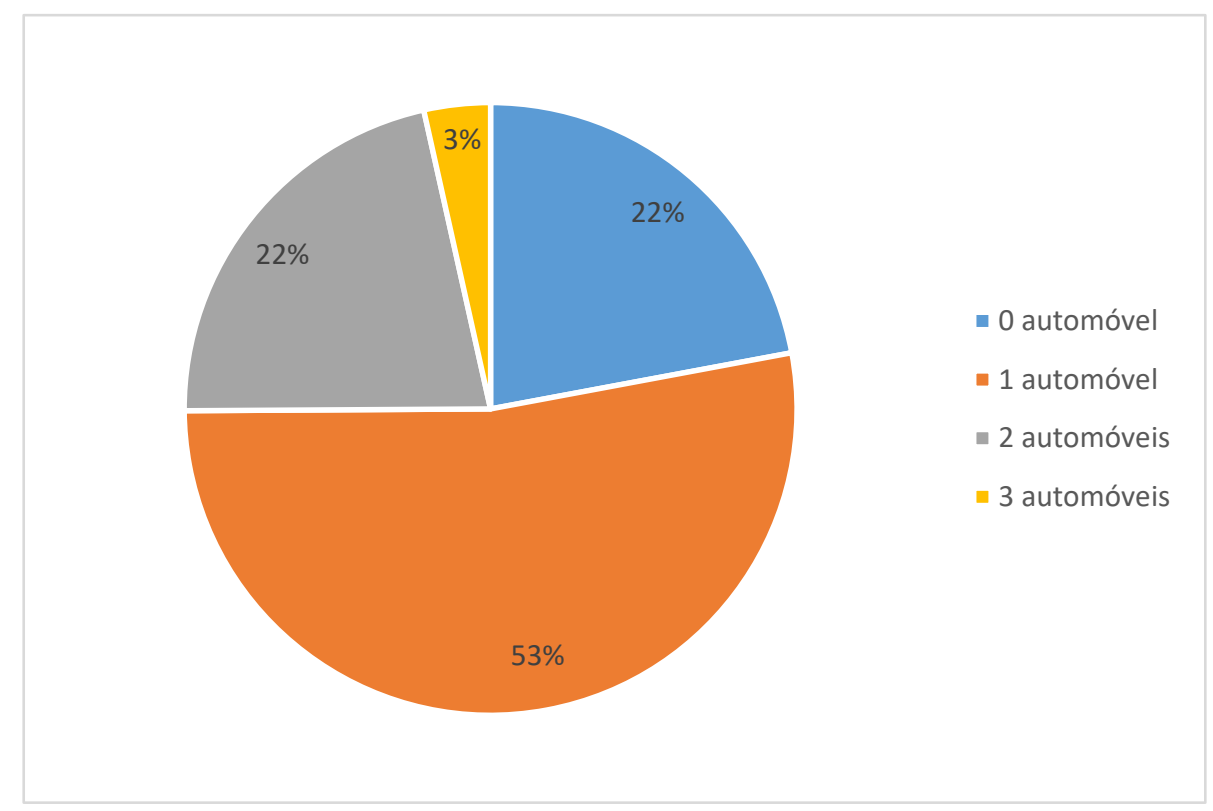

Figura 6.9 - Número de veículos na cidade de Goiânia das famílias pesquisadas

Em se tratando da cidade de Goiânia, observa-se que mais da metade das famílias que possuem filhos no ensino fundamental possuem pelo menos 1 veículo (53\%), enquanto $22 \%$ dessas famílias não possuem nenhum veículo automotor. 
- Quem Acompanha Normalmente seu Filho até a Escola?

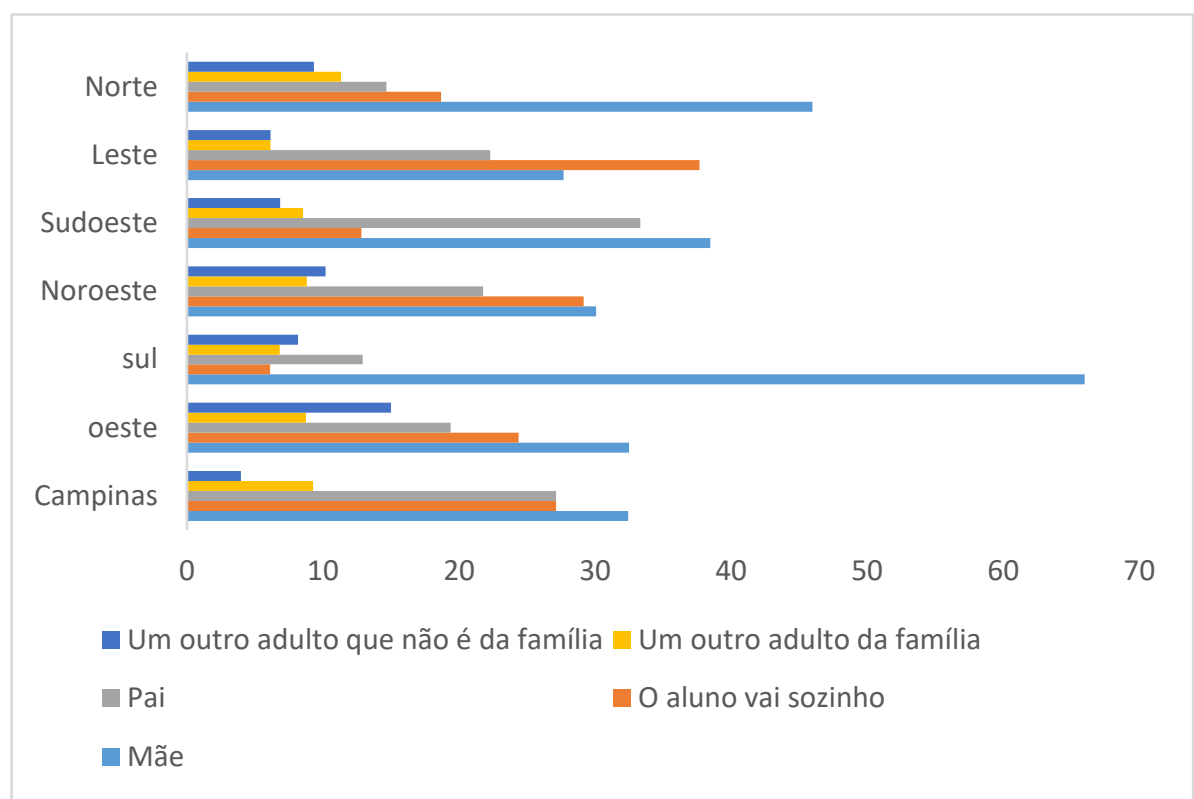

Figura 6.10 - Acompanhante das crianças até a escola/região das famílias pesquisadas

Os gráficos para essa variável mostram uma tendência que é mundial. Em todas as regiões a mãe é a principal responsável por acompanhar seu filho até a escola, fato já relatado no capítulo 2 e demonstram que Goiânia não está distante de uma realidade mundial. Na região Sul, $66 \%$ das mães conduzem seus filhos contra $13 \%$ dos pais. Já na região Leste $38 \%$ dos alunos vão à escola sozinho, $28 \%$ com a mãe e $22 \%$ com o pai.

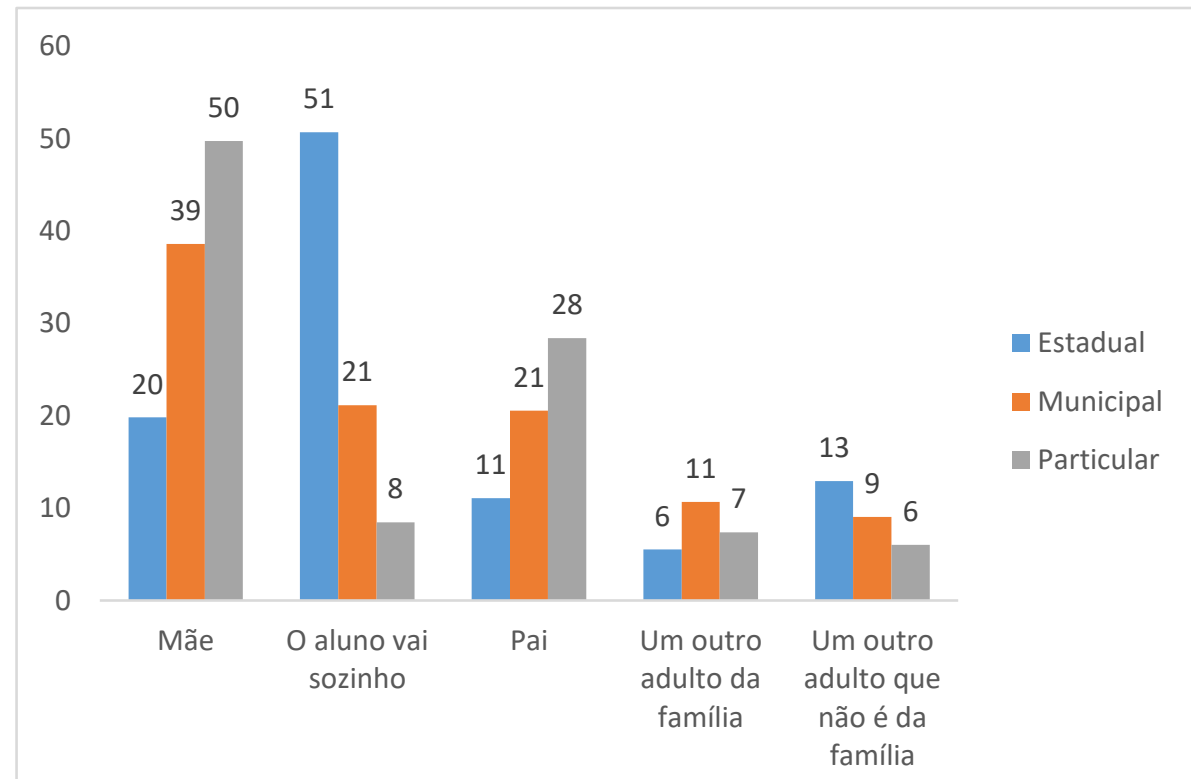

Figura 6.11 - Acompanhante das crianças até a escola/rede das famílias pesquisadas 
Observando o comportamento por rede de ensino, observa-se que $50 \%$ dos alunos da rede particular são acompanhados pela mãe até a escola, 51\% dos alunos da rede estadual vão sozinho e 39\% dos alunos da rede municipal são acompanhados pela mãe. Em Goiânia 38\% dos alunos vão até a escola acompanhados pela mãe enquanto $21 \%$ pelo pai.

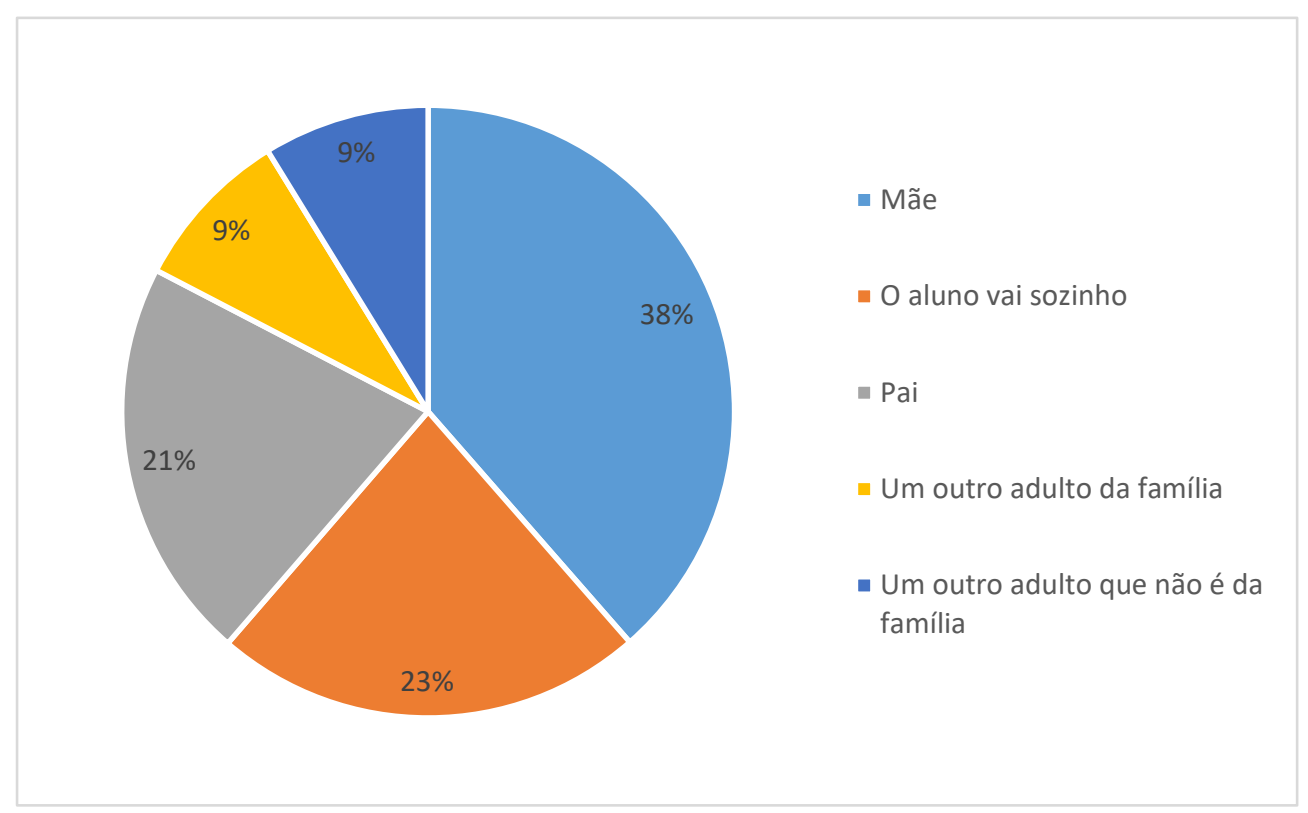

Figura 6.12 - Acompanhante das crianças até a escola na cidade de Goiânia das famílias pesquisadas

Analisando a cidade de Goiânia observa-se no gráfico 6.12 que $38 \%$ dos alunos se deslocam à escola acompanhados pela mãe, $23 \%$ seguem sozinho enquanto $21 \%$ são conduzidos pelo pai.

\section{- Idade das Crianças}

Como citado anteriormente a pesquisa foi realizada com crianças do ensino fundamental cuja as idades variam de 6 a 14 anos. Tomou-se o cuidado de manter certas proporções para que todas as idades fossem pesquisadas. No entanto as escolas da rede estadual de ensino fundamental em Goiânia não foram contempladas na pesquisa com idade da criança variando de 6 a 8 anos. Um fato que pode explicar tal ausência, pode ser que as idades mencionadas (ciclo I) constam com maior número de vagas nas escolas municipais, portanto, as escolas estaduais oferecem um número reduzido de vagas para tal ciclo. 


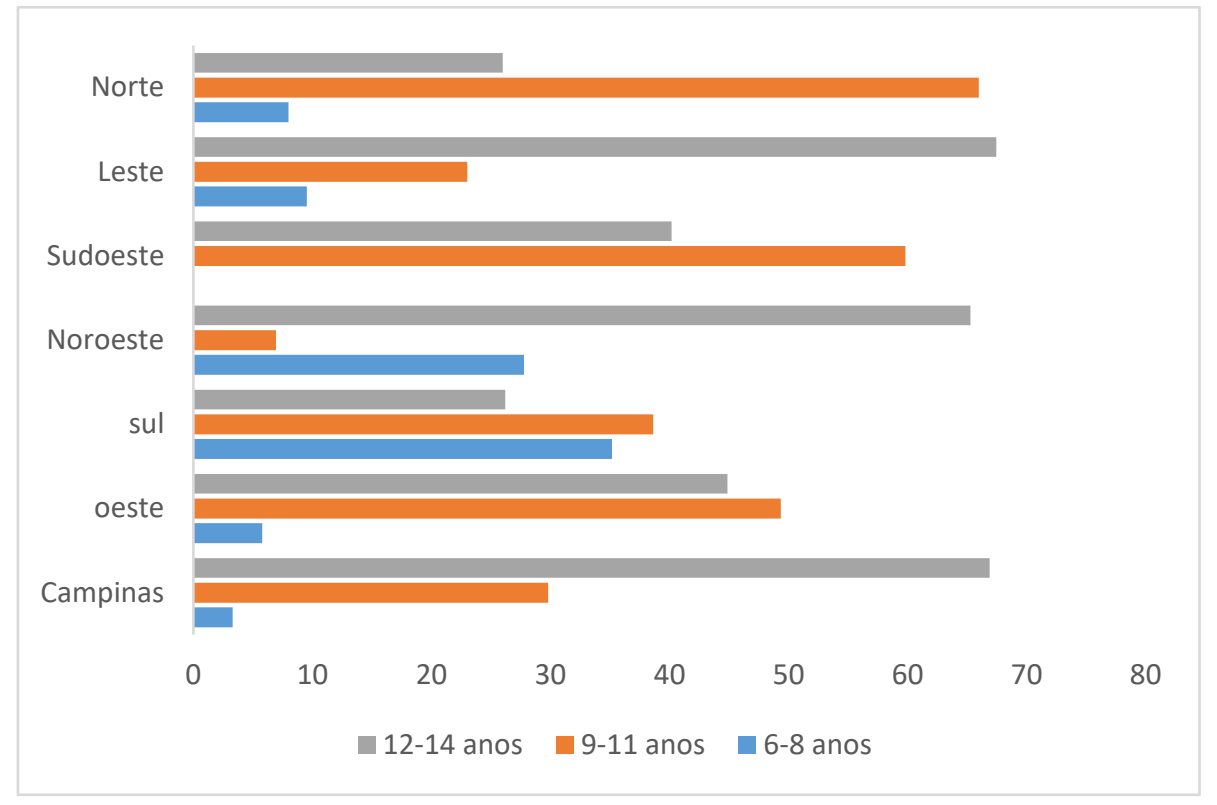

Figura 6.13 - Idade das crianças/região das famílias pesquisadas

No gráfico 6.13 é mostrado que o intervalo de idade 6-8 anos foi o menos pesquisado nas regiões Norte, Leste, Oeste e Campinas. O intervalo que compreende a idade 1214 anos foi o maior entre os pesquisados das regiões Leste, Noroeste e Campinas.

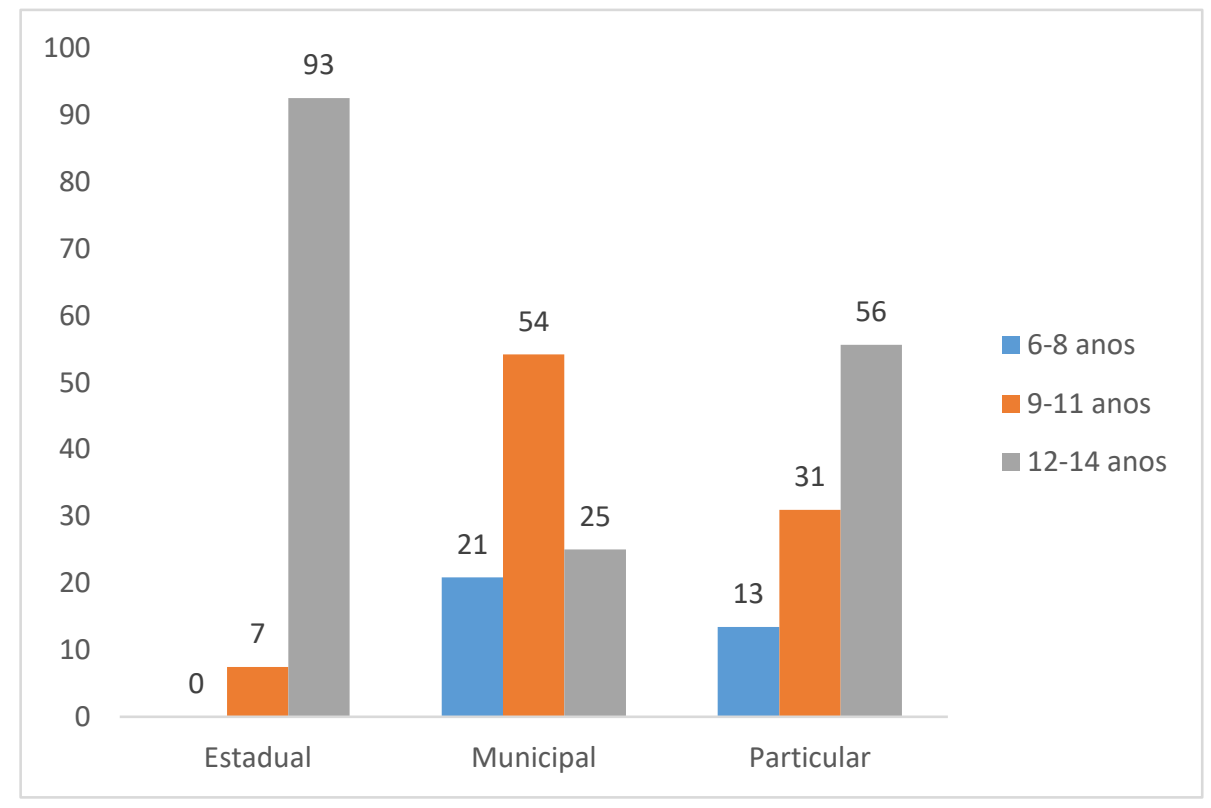

Figura 6.14 - Idade das crianças/rede das famílias pesquisadas

O gráfico da figura 6.14 demonstra que $93 \%$ dos alunos da rede estadual estão entre as idades de 12-14 anos o que poderia explicar a maior parte destes se deslocarem sozinhos até a escola e evidenciado no gráfico 6.11 . No entanto $56 \%$ dos entrevistados 
das escolas particulares também estão entre 12-14 anos de idade, e ainda assim, 78\% destes são conduzidos pela mãe ou pai.

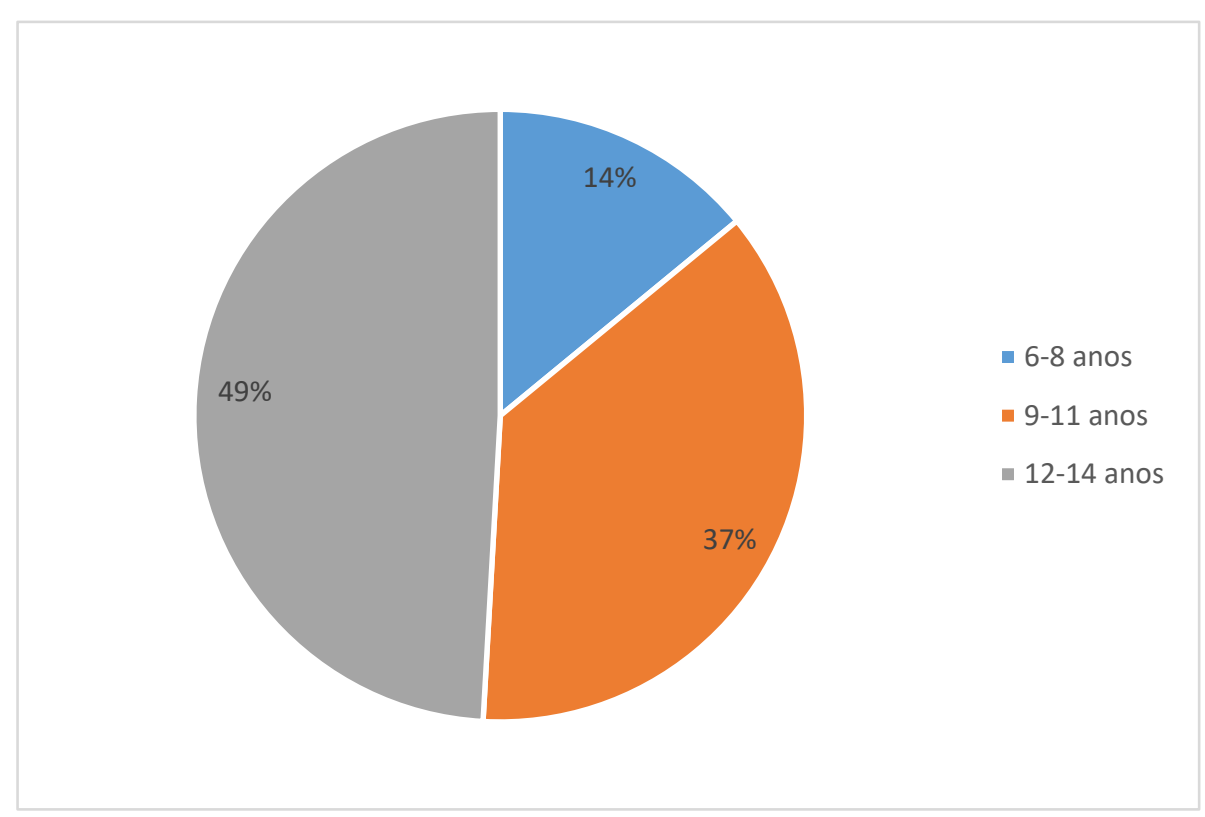

Figura 6.15 - Idade das crianças na cidade de Goiânia das famílias pesquisadas

As idades pesquisadas tomando Goiânia como referência, foi 49\% de 12 a 14 anos, $37 \%$ de $9-11$ anos e $14 \%$ de $6-8$ anos.

- Grau de Instrução dos Pais

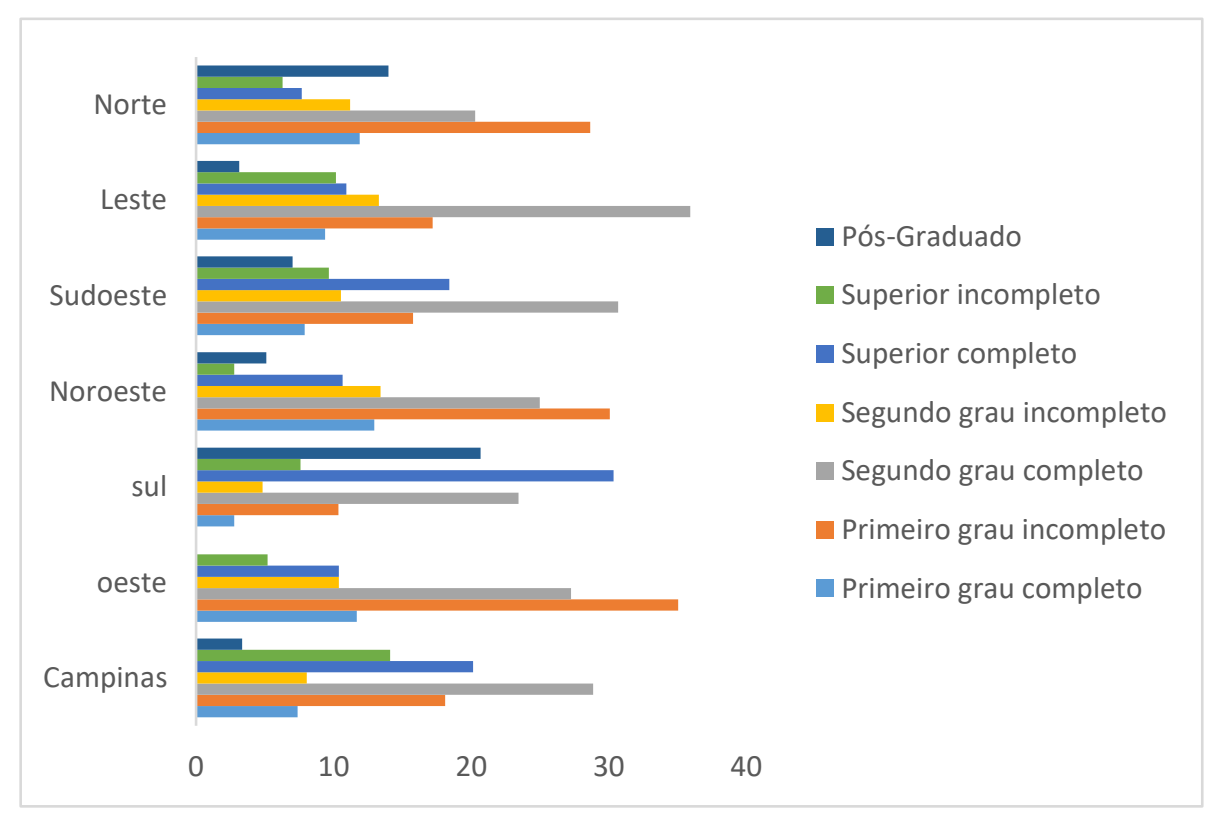

Figura 6.16 - Grau de Instrução dos pais/região das famílias pesquisadas 
Os gráficos sobre o grau de instrução dos pais, mostram que a maior parte dos pais da região Norte, Noroeste e Oeste - 29\%, 30\% e 35\% respectivamente possuem o primeiro grau incompleto, enquanto a maior percentagem dos pais da região Leste, Sudoeste e Campinas - 36\%, 31\% e 29\% respectivamente possuem o segundo grau completo. Novamente a região Sul de destaca dentre as demais e evidencia que $30 \%$ dos pais entrevistados possuem nível superior completo.

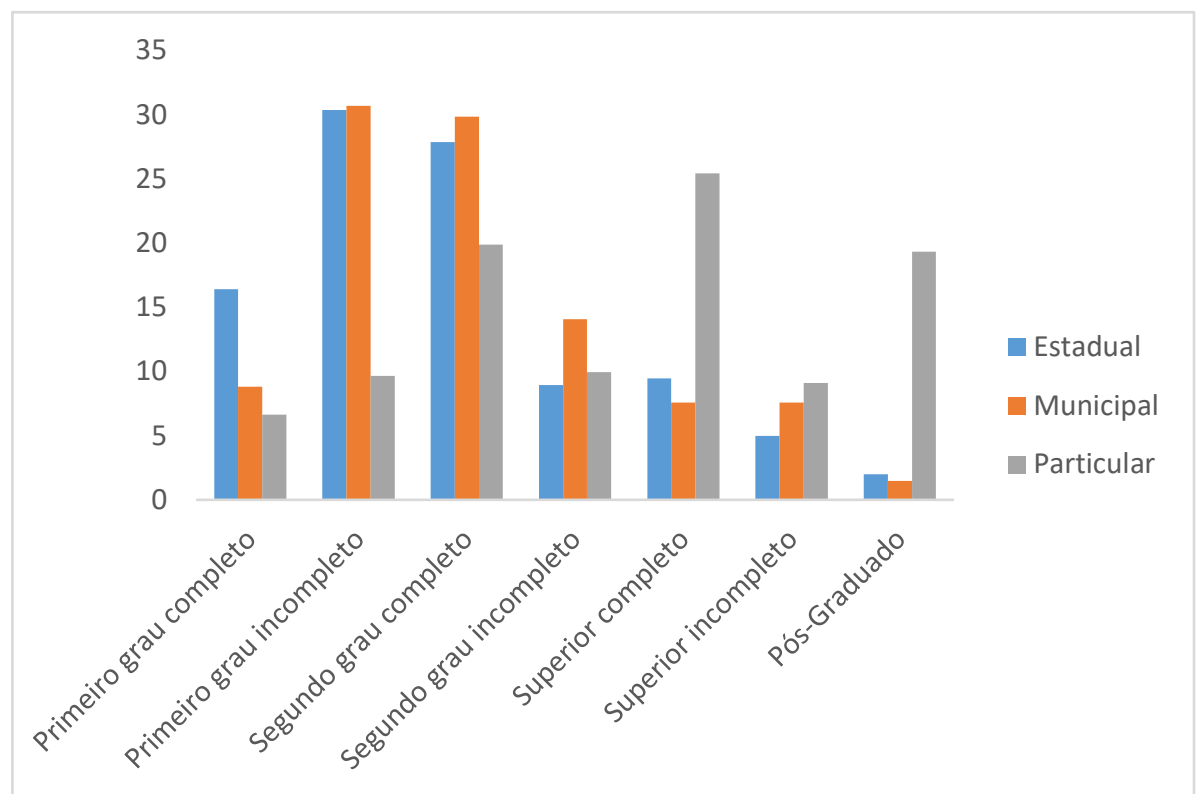

Figura 6.17 - Grau de instrução dos pais/rede das famílias pesquisadas

Pode-se observar no gráfico 6.17 a maior percentagem entre o menor grau de instrução (primeiro grau incompleto) está entre os pais da rede estadual e municipal, e dentre as percentagens para escola da rede particular, a maior $25 \%$ são dos pais que possuem nível superior completo

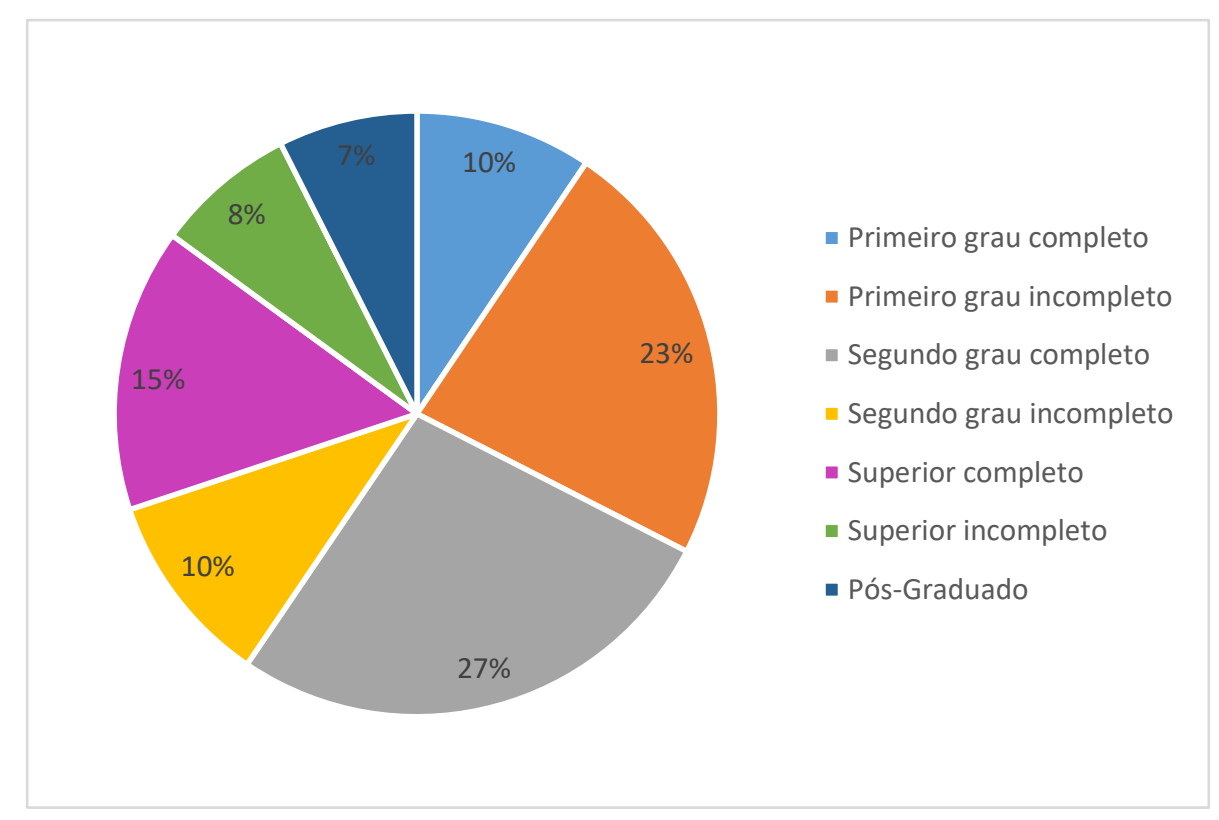

Figura 6.18 - Grau de instrução dos pais na cidade de Goiânia das famílias pesquisadas 
Considerando a cidade de Goiânia, nessa pesquisa, as maiores percentagens para o grau de instrução foram $27 \%$ e $23 \%$, respectivamente, e referem-se ao segundo grau completo e primeiro grau incompleto.

- Tempo de Deslocamento até a Escola

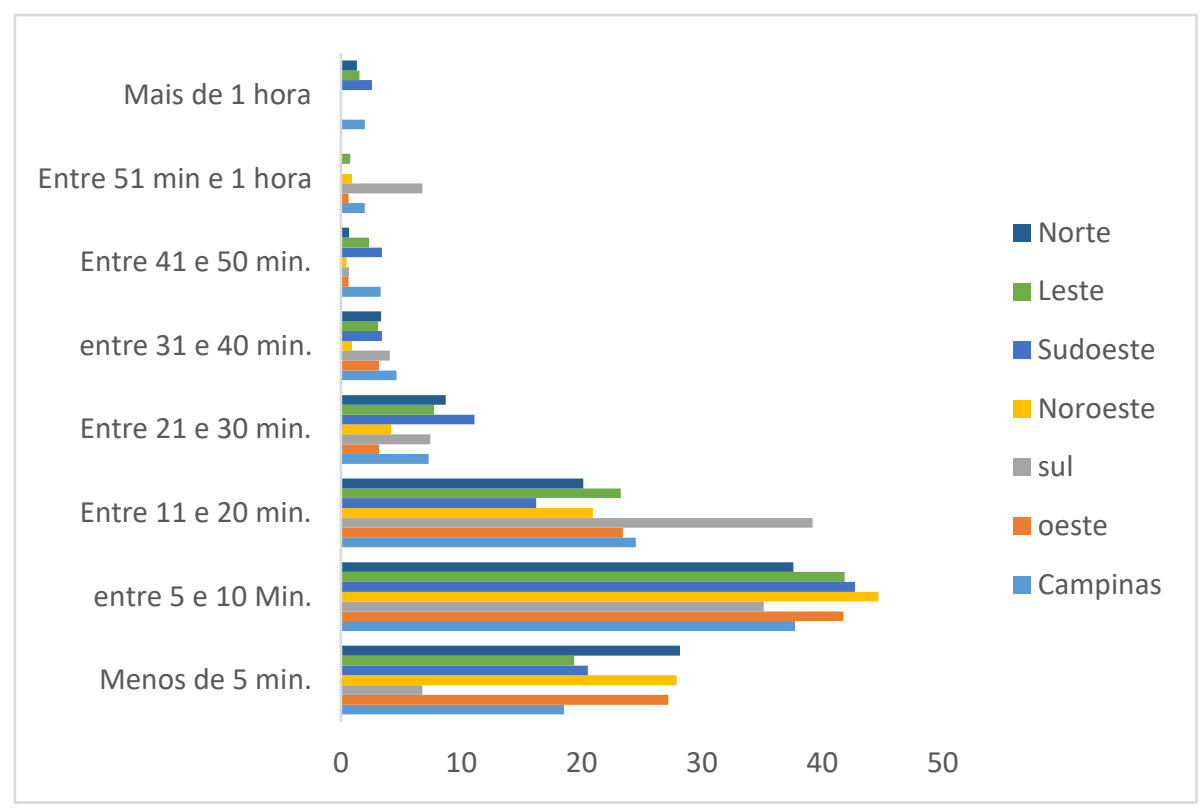

Figura 6.19 - Tempo de deslocamento até a escola/região das famílias pesquisadas

O gráfico 6.19 sobre o tempo de deslocamento por região administrativa revela que em todas as regiões, a maior percentagem para o tempo de deslocamento até a escola, estão entre 5-10 min

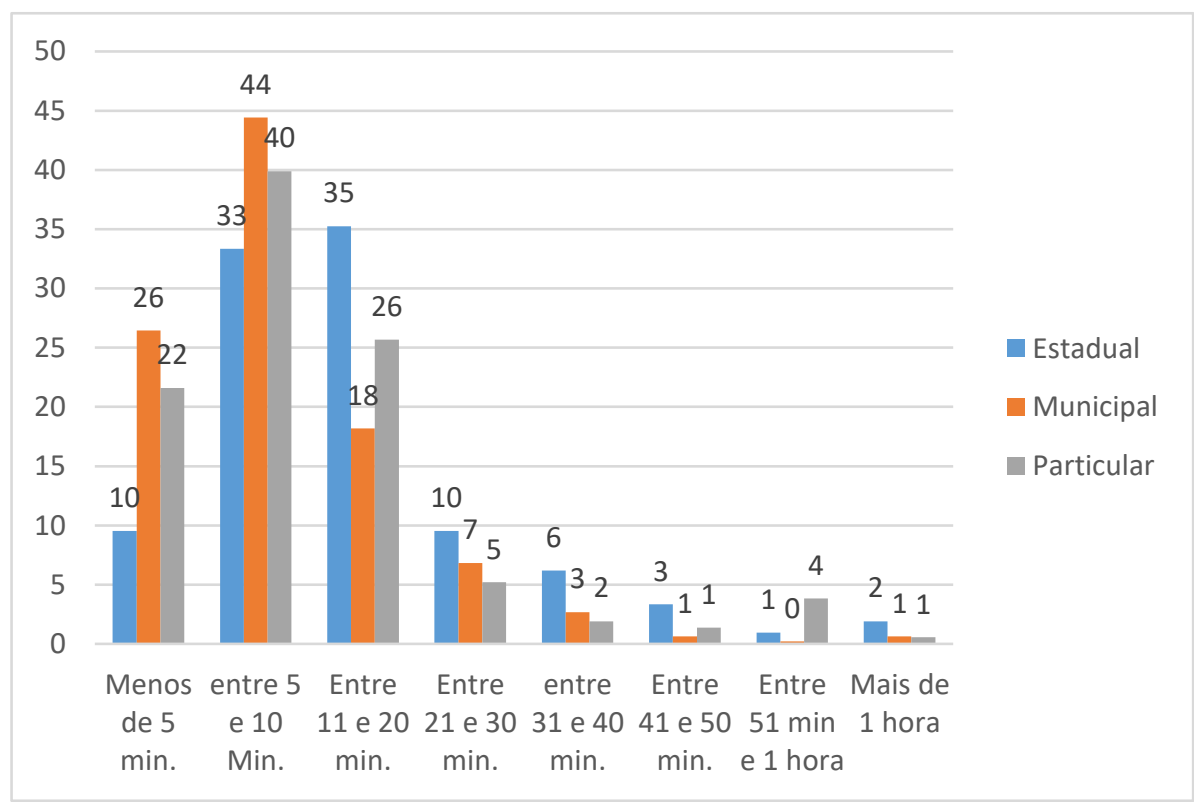

Figura 6.20 - Tempo de deslocamento até a escola/rede das famílias pesquisadas 
O mesmo se repete quando a referência é a rede de ensino, e observa-se no gráfico 6.20 que a grande maioria dos entrevistados responderam que gastam entre 5 a $10 \mathrm{~min}$. para chegar na escola.

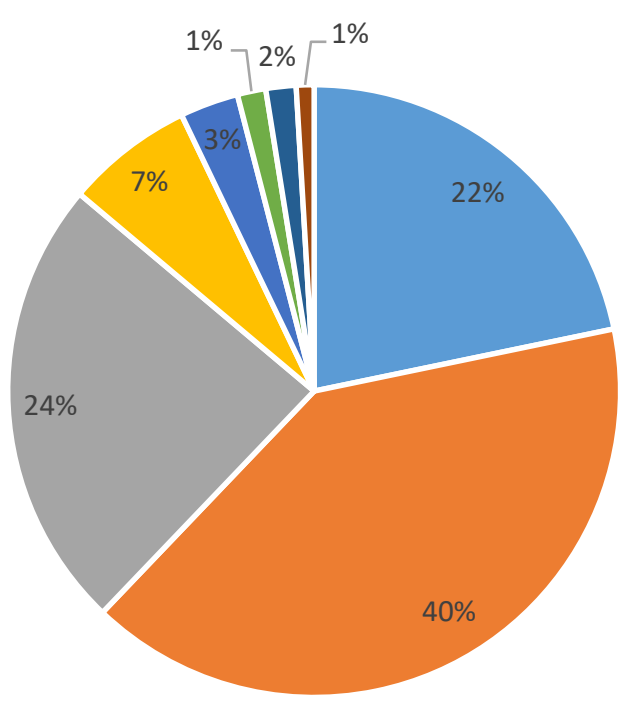

- Menos de 5 min.

- entre 5 e 10 Min.

- Entre 11 e 20 min.

- Entre 21 e 30 min.

- entre 31 e $40 \mathrm{~min}$.

- Entre 41 e $50 \mathrm{~min}$.

- Entre 51 min e 1 hora

- Mais de 1 hora

Figura 6.21 - Tempo de deslocamento até a escola na cidade Goiânia das famílias pesquisadas

Em Goiânia 40\% dos alunos do ensino fundamental gastam de 5 a 10 min. para chegar até a escola; $22 \%$ menos de $5 \mathrm{~min}$. e $24 \%$ entre 11 e $20 \mathrm{~min}$, sendo as percentagens mais significativas do gráfico 6.21. Fazendo uma avaliação entre os gráficos da pesquisa, observa-se que apesar da maior parte das crianças que cursam o ensino fundamental em Goiânia gastarem entre 5-10 min. para fazer tal deslocamento, o modo de transporte preferencial entre os pais é outros (automóvel, moto, van escolar) como evidencia o gráfico 6.3.

\section{- Influência na Escolha da Escola}

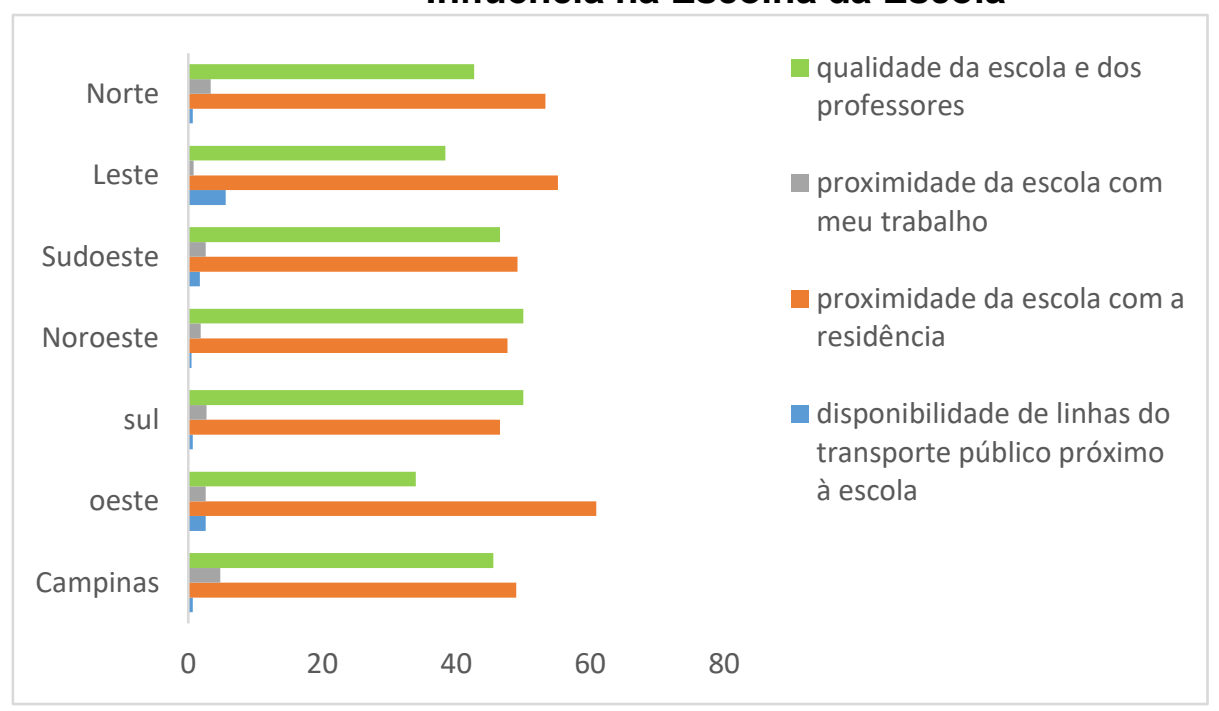

Figura 6.22 - Influência na escolha da escola/região das famílias pesquisadas 
Quando perguntados o que influenciou a escolha da escola dos filhos, a maior parte dos pais da região Campinas, Oeste, Sudoeste, Leste e Norte (49\%, 61\%, 49\%, 55\% e 53\% respectivamente) responderam que foi a proximidade da escola com a residência. Os pais da região Sul e Noroeste $(50 \%)$ responderam que escolheram a escola de seus filhos pela qualidade da mesma e dos professores.

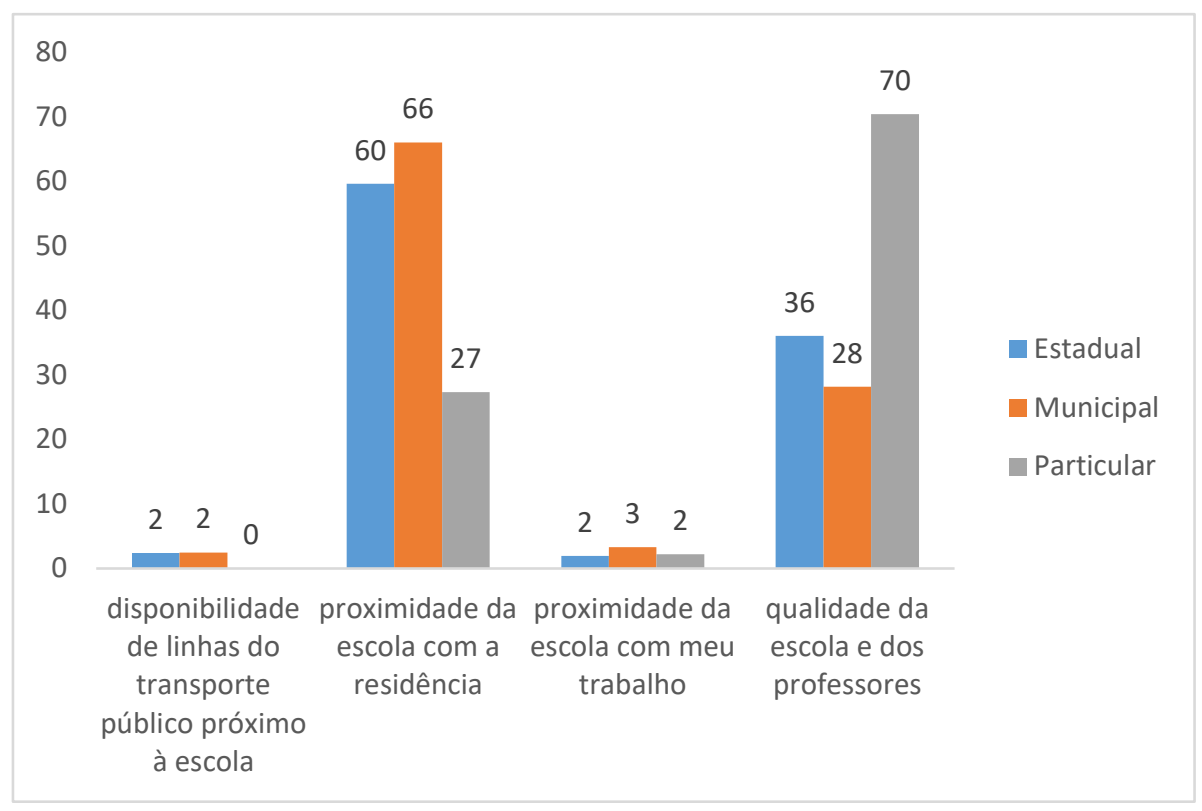

Figura 6.23 - Influência na escolha da escola/rede das famílias pesquisadas

Analisando a escolha da escola por rede de ensino pode-se observar pelo gráfico que mais de $60 \%$ dos pais das redes estaduais e municipais escolheram a escola dos seus filhos pela proximidade das mesmas com a residência. Entre os pais da rede particular, $70 \%$ fez a escolha da escola pela qualidade da mesma e dos professores.
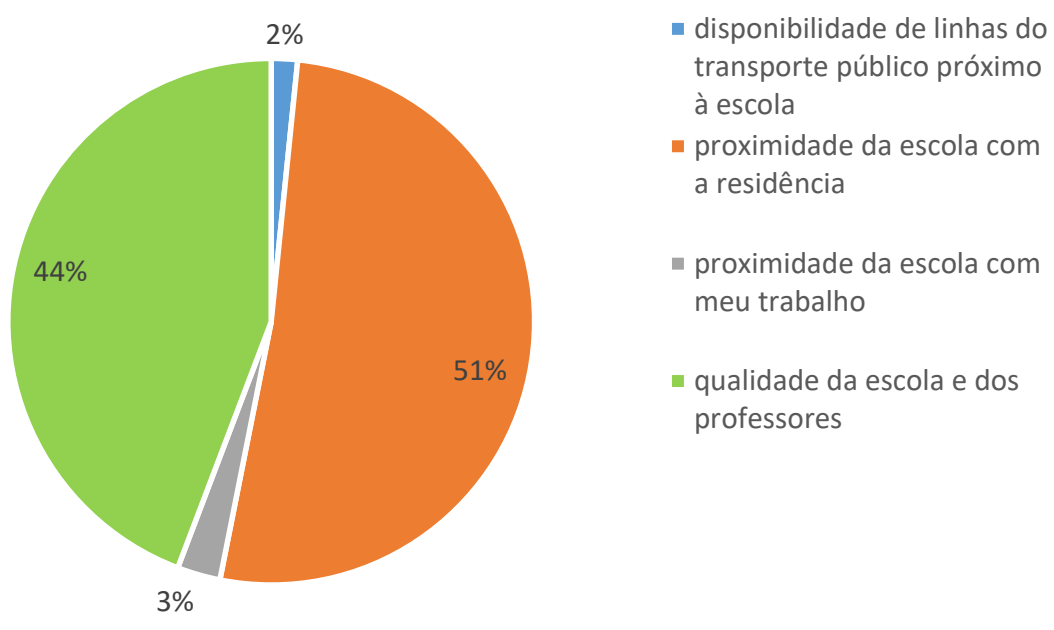

- disponibilidade de linhas do transporte público próximo à escola

- proximidade da escola com a residência

- proximidade da escola com meu trabalho

- qualidade da escola e dos professores

Figura 6.24 - Influência na escolha da escola na cidade de Goiânia das famílias pesquisadas 
Em Goiânia a maior parte dos pais com filhos no ensino fundamental $(51 \%)$ escolhem a escola de seus filhos pela proximidade da mesma com suas residências, (44\%) pela qualidade da escola e dos professores, $(3 \%)$ pela proximidade da escola com seus trabalhos e apenas (2\%) pela disponibilidade de transporte público próximo à escola. Muitas pesquisas já mencionadas no capítulo 2 desse trabalho, descrevem a distância como uma variável influente na escolha do modo de transporte.

\subsection{RESULTADOS OBTIDOS SOBRE A PERCEPÇÃO DOS PAIS QUANTO À IMPORTÂNCIA DAS VARIÁVEIS FORMA URBANA ASSIM COMO AS VARIÁVEIS MODERADORAS E MEDIADORAS NAS VIAGENS ESCOLARES EM GOIÂNIA}

Os pais dos alunos estudados, foram perguntados também sobre uma série de fatores, que não são variáveis da forma urbana, no entanto, servem de moderadoras ou mediadoras no modelo de decisão de escolha dos pais sobre o modo de transportar seus filhos até a escola. Os gráficos a seguir mostram a percepção dos pais em relação às variáveis como: tráfego de veículo, iluminação pública, segurança do bairro, idade dos filhos, clima da cidade, atitude dos pais em relação às escolhas dos filhos e também sobre questões ligadas a forma urbana como distância da residência até a escola.

\section{- Percepção dos Pais Quanto as Variáveis da Forma Urbana}

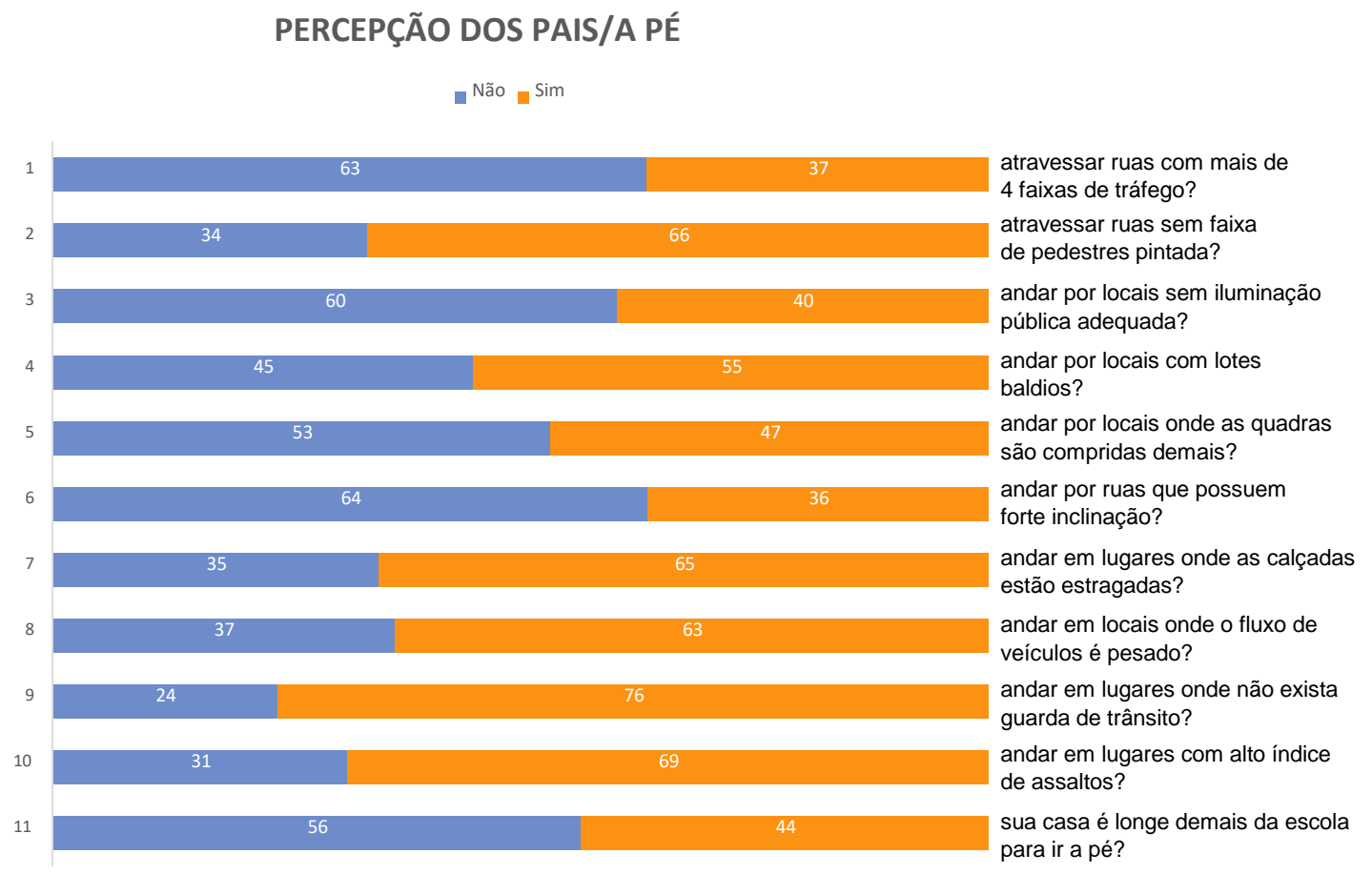

Figura 6.25 - Percepção dos pais quanto as variáveis da forma urbana nos deslocamentos a pé em Goiânia 
No gráfico 6.25 observa-se que mais da metade dos alunos das escolas do ensino fundamental de Goiânia (63\%) não atravessam ruas com mais de quatro faixas de tráfego para chegar até a escola. Por outro lado, segundo os pais pesquisados, $66 \%$ desses alunos atravessam ruas sem faixas de pedestre pintada no pavimento. Dos alunos estudados $60 \%$ não andam por locais sem iluminação pública adequada, 55\% caminham por lotes vazios, $53 \%$ consideram que não caminham por quadras compridas demais e 64\% consideram que não andam por ruas com forte inclinação. Quanto ao estado de conservação das calçadas $65 \%$ consideram que para chegar até a escola percorrem lugares com calçadas estragadas, $63 \%$ caminham por lugares com alto fluxo de veículos e $76 \%$ andam por locais onde não existe guarda de trânsito. Segundo os pais pesquisados $69 \%$ relataram que para se deslocar a pé seus filhos andam por locais com alto índice de assaltos e $56 \%$ destes não moram longe da escola o suficiente para não utilizar esse modo de deslocamento.

\section{PERCEPÇÃO DOS PAIS/BICICLETA}

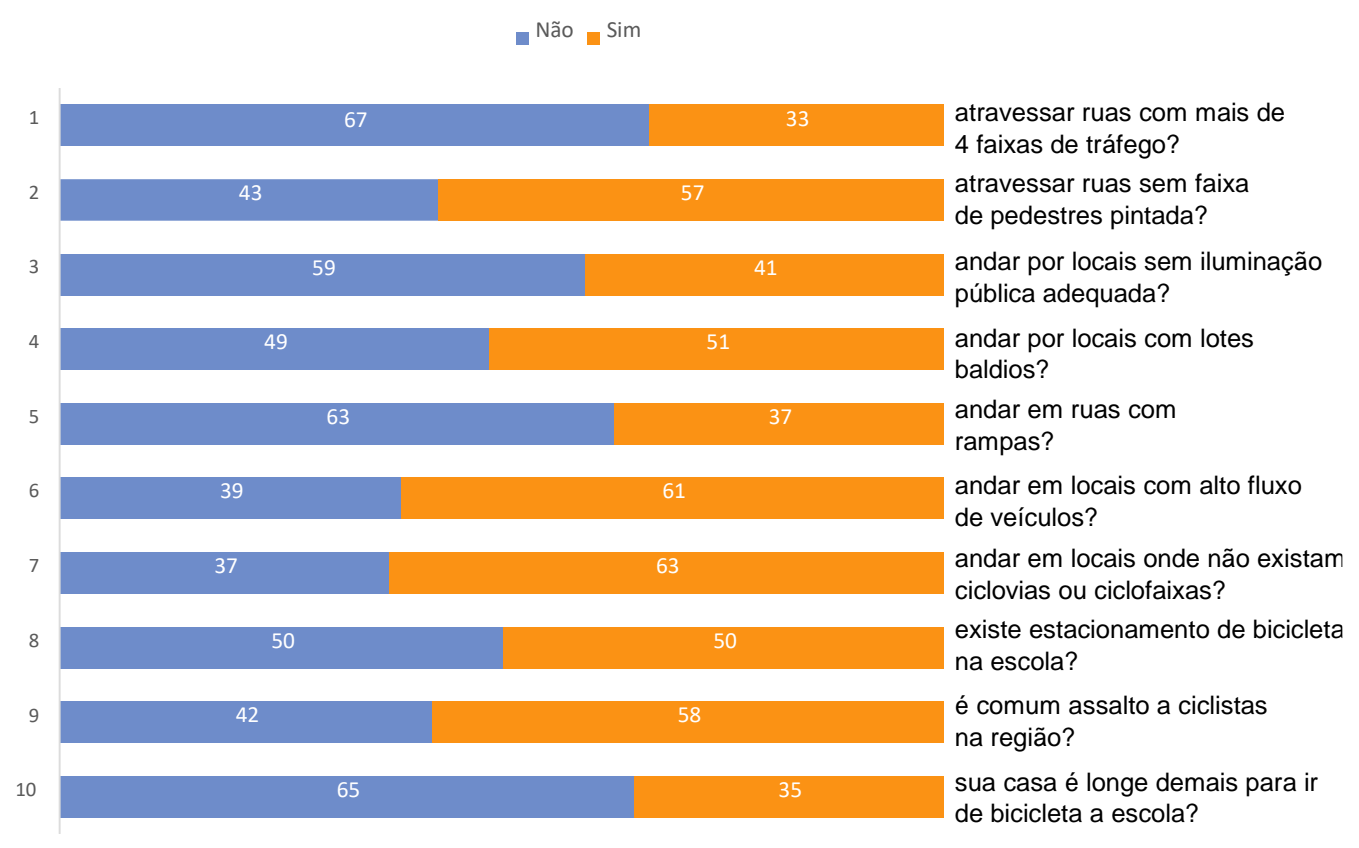

Figura 6.26 - Percepção dos pais quanto as variáveis da forma urbana nos deslocamentos por bicicleta em Goiânia

Segundo percepção dos pais quanto ao modo bicicleta, $64 \%$ consideram que seus filhos não atravessariam quatro faixas de tráfego se utilizasse esse modo para se deslocar até a escola. Já $57 \%$ dos pais consideram que seus filhos atravessam ruas sem faixa 
de pedestre pintada, $59 \%$ não andam por locais sem iluminação pública, 51\% atravessam lotes vazios, 63 \% não percorrem ruas com forte inclinação. Quanto à segurança viária $61 \%$ pedalam por lugares com movimento intenso de fluxo de veículos e $63 \%$ não são servidos por ciclovias ou ciclofaixas. Metade dos pais pesquisados informaram que não existem estacionamentos para bicicleta na escola do seu filho, $58 \%$ relatam que é comum assaltos no bairro onde moram e $65 \%$ afirmam que sua casa não é longe demais da escola para que seu filho se desloque de bicicleta até ela.

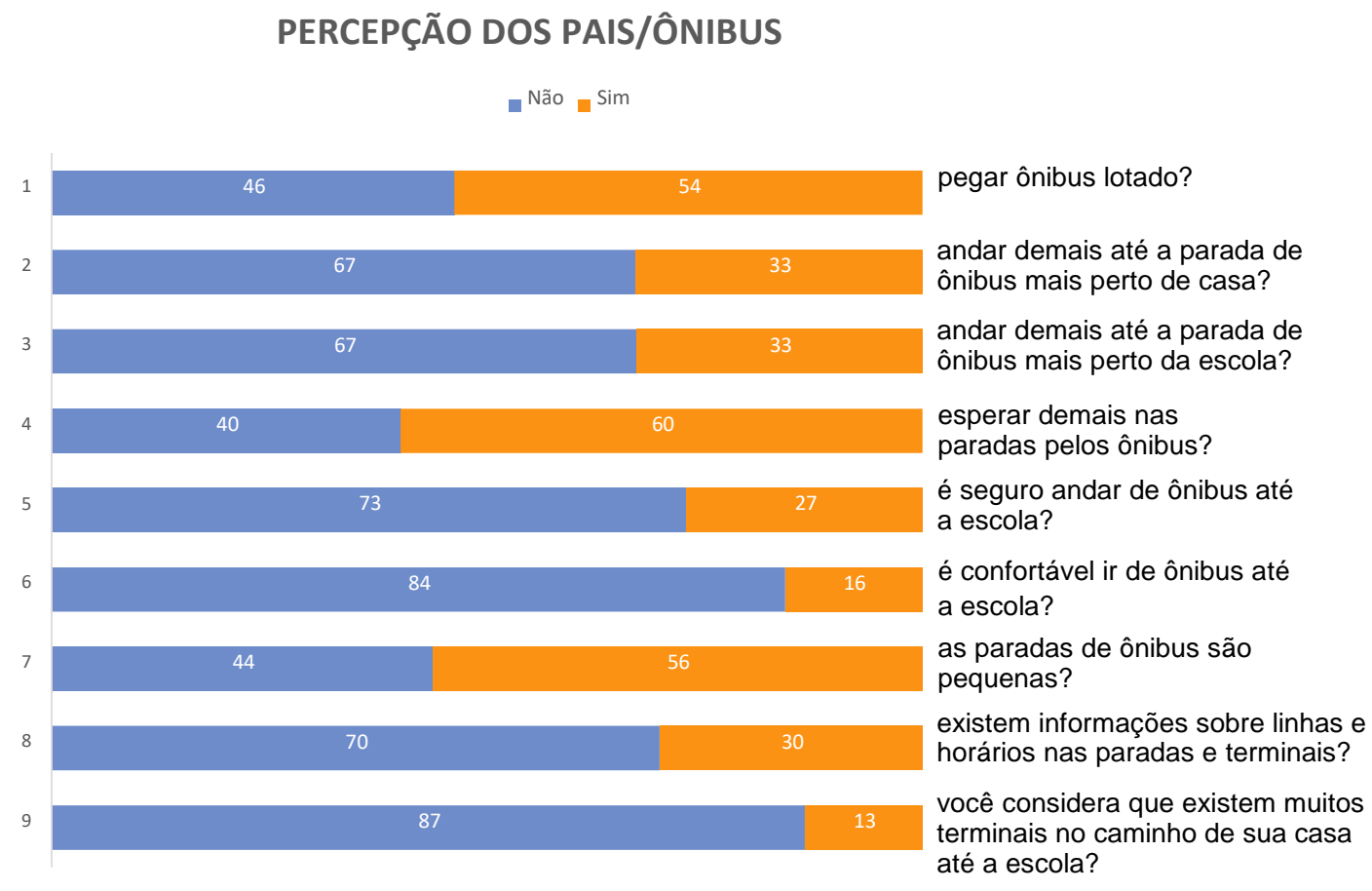

Figura 6.27 - Percepção dos pais quanto as variáveis da forma urbana nos deslocamentos por ônibus/Goiânia

Quanto à utilizar o ônibus para deixar o filho na escola $54 \%$ responderam que pegariam ônibus lotado para fazer essa viagem, $67 \%$ não precisariam andar demais até a parada mais próxima da residência nem tampouco da parada mais perto da escola. Dos pais entrevistados, $60 \%$ afirmam que precisariam esperar muito até a chegada do ônibus, ou seja, a frequência dos ônibus em Goiânia não é satisfatória segundo percepção destes. Quando o assunto é segurança, 73\% dos pais relataram não ser seguro viajar de ônibus até a escola e $84 \%$ diz não ser confortável tal deslocamento. Segundo os entrevistados $56 \%$ afirmam que as paradas de ônibus são pequenas demais e não abrigam do calor ou chuva, $70 \%$ relatam não existir informações sobre os horários de partida e chegada dos ônibus nas paradas e terminais e $87 \%$ não consideram existir muitos abrigos na rota entre a escola e a residência. 


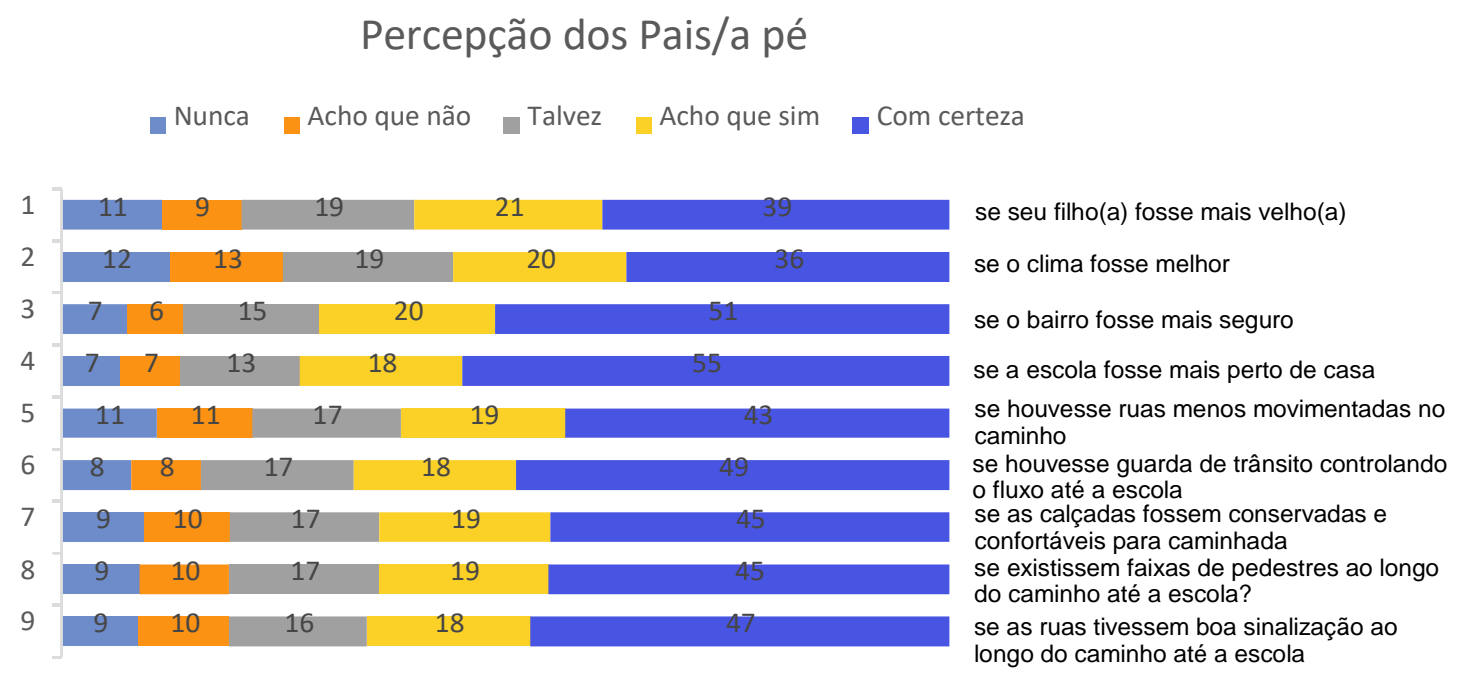

Figura 6.28 - Percepção dos pais quanto as variáveis moderadoras/mediadoras deslocamentos a pé/Goiânia

O gráfico 6.28 evidencia que quando perguntados sobre questões como idade dos filhos; clima; segurança do bairro; distância da escola até a residência; segurança do tráfego; agentes de trânsito; condição das calçadas; faixas de pedestre; sinalização viária, a grande maioria dos entrevistados (36\% a 55\%) responderam que "com certeza" deixariam seu filho se deslocar a pé até a escola se existissem boas condições para todas as variáveis

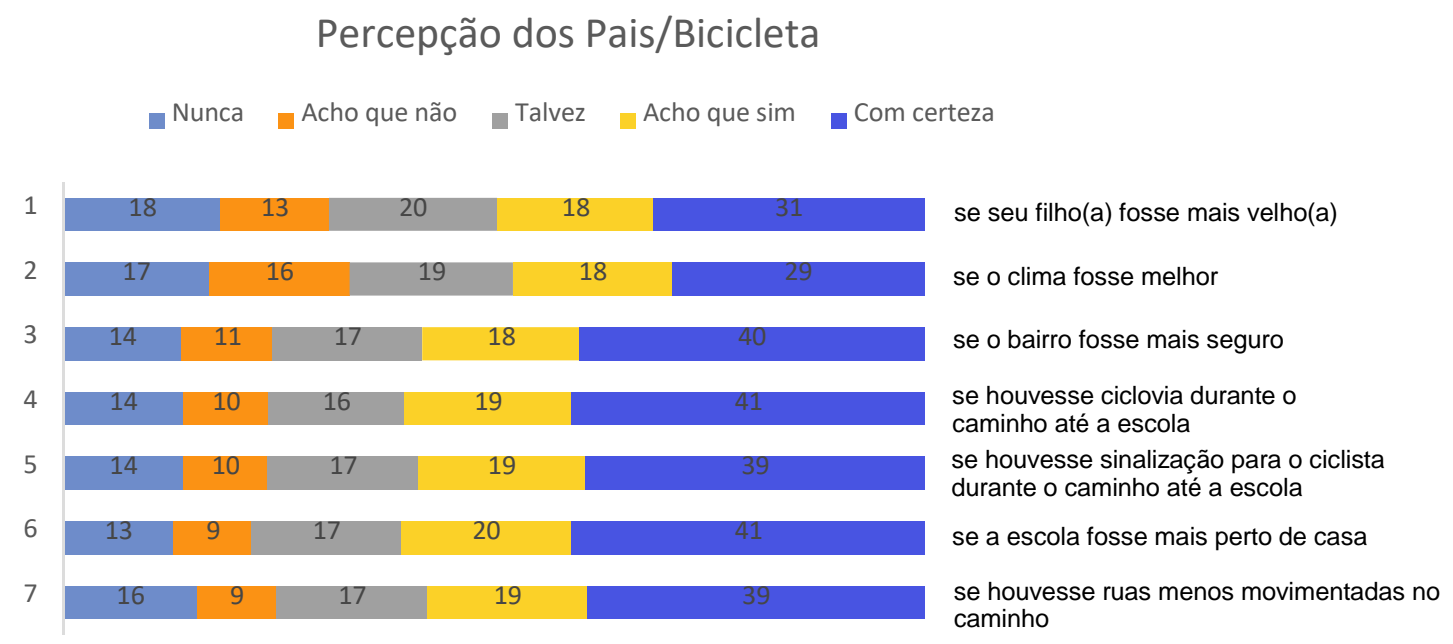

Figura 6.29 - Percepção dos pais quanto as variáveis moderadoras/mediadoras deslocamentos por bicicleta/Goiânia

O mesmo fato se observou para os deslocamentos realizados por bicicletas e a maior parte dos entrevistados responderam que "com certeza" deixariam seus filhos se 
deslocarem de bicicleta até a escola se as variáveis: idade da criança; clima; segurança do bairro; ciclovias; sinalização para ciclistas; distância da escola até a residência; segurança do tráfego, se todas estivessem em boas condições.

\section{Percepção dos Pais/ônibus}

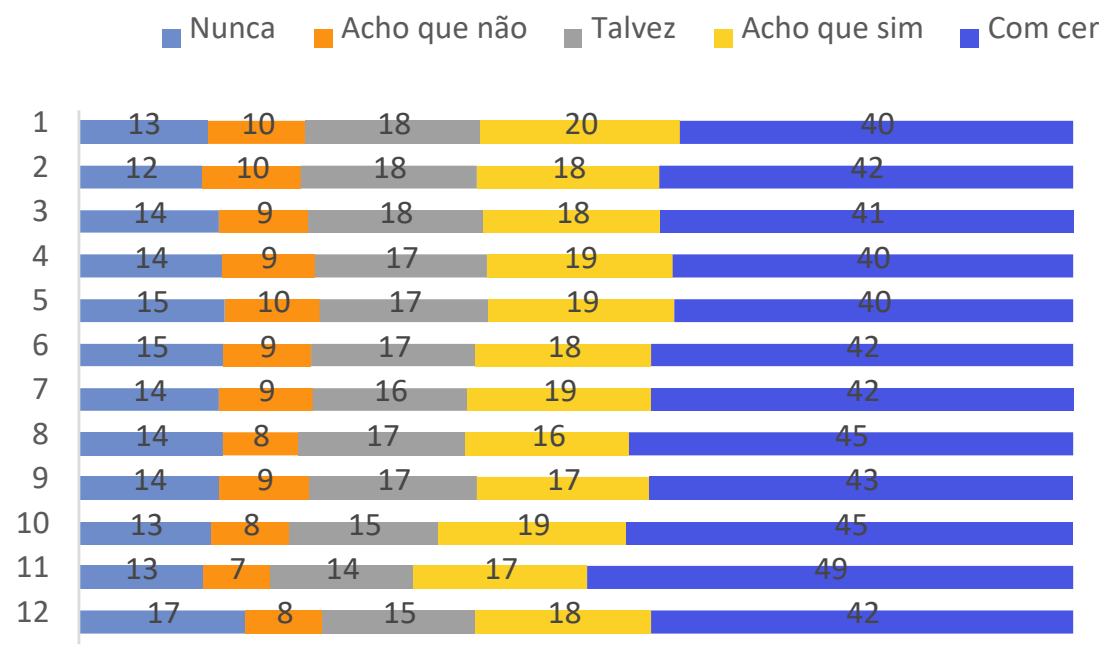

se seu filho(a) fosse mais velho(a) se as paradas de ônibus fossem maiores e seguras se existissem paradas de ônibus perto de casa se existissem paradas de ônibus perto da escola se houvesse mais linhas de ônibus se andar de ônibus fosse mais rápido se os ônibus fossem pontuais se os ônibus não fossem lotados se os ônibus estivessem novos e limpos se andar de ônibus fosse mais confortável se andar de ônibus fosse mais seguro se os ônibus passassem nos horários marcados nas planilhas

Figura 6.30 - Percepção dos pais quanto as variáveis moderadoras/mediadoras deslocamentos por ônibus/Goiânia

Para os deslocamentos realizados por ônibus, a maior parte dos entrevistados ( $41 \%$ a $49 \%$ ), responderam que "com certeza" deixaria seu filho se deslocar por esse modo até a escola se as variáveis: idade da criança; paradas de ônibus maiores e segura; paradas próximas da residência; paradas próximas da escola; maior número de linhas de ônibus; tempo de deslocamento; pontualidade; lotação; frota renovada; conforto; segurança; pontualidade; se todas estivessem em boas condições.

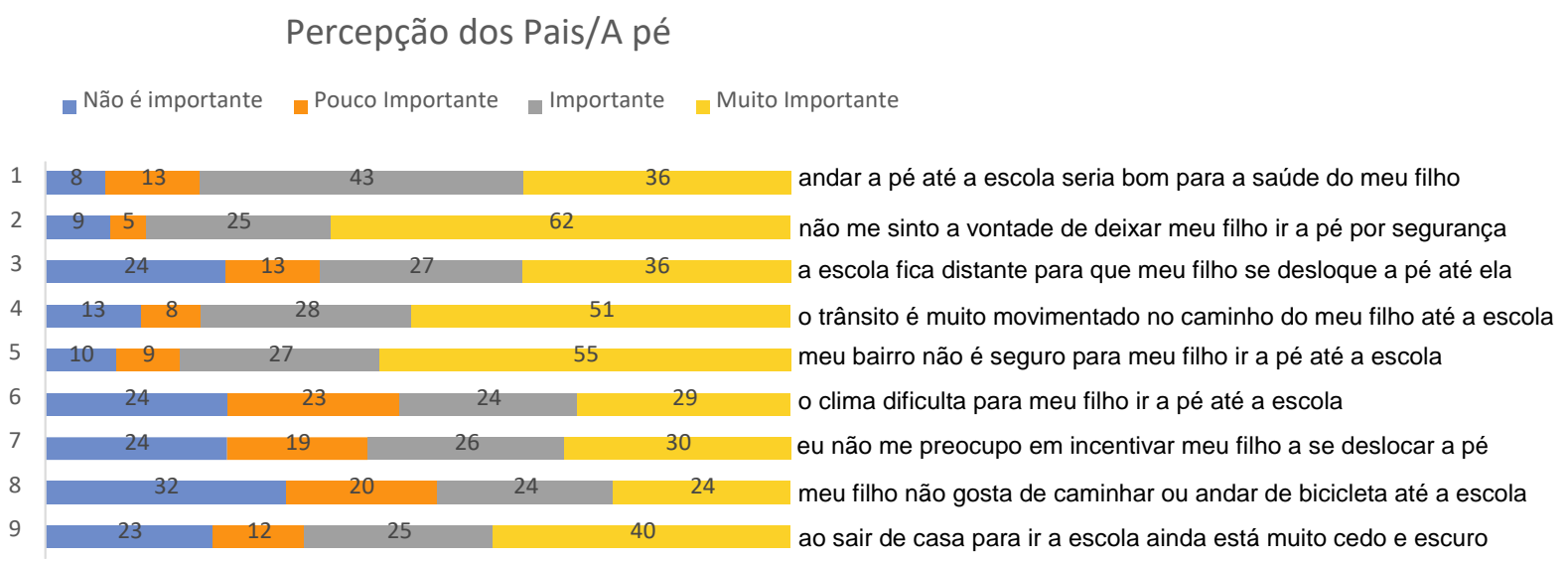

Figura 6.31 - Percepção dos pais quanto à importância das variáveis forma urbana moderadoras - mediadoras no deslocamento a pé/Goiânia 
Observa-se no gráfico que os pais consideram "muito importante" no deslocamento a pé das crianças até a escola, questões como: saúde; abordagem de estranhos; distância da escola à residência; segurança do tráfego; segurança do bairro; clima. Apesar de $30 \%$ dos entrevistados considerarem "muito importante" a educação dos filhos sobre o deslocamento a pé, $24 \%$ dos mesmos, consideram que "não é importante" tal fator. $32 \%$ dos pais declararam ainda que o filho não gostar de ir a pé até a escola "não é um fator importante". $40 \%$ consideram "muito importante" o fato de ao sair de casa ainda estar muito cedo e escuro para andar a pé.

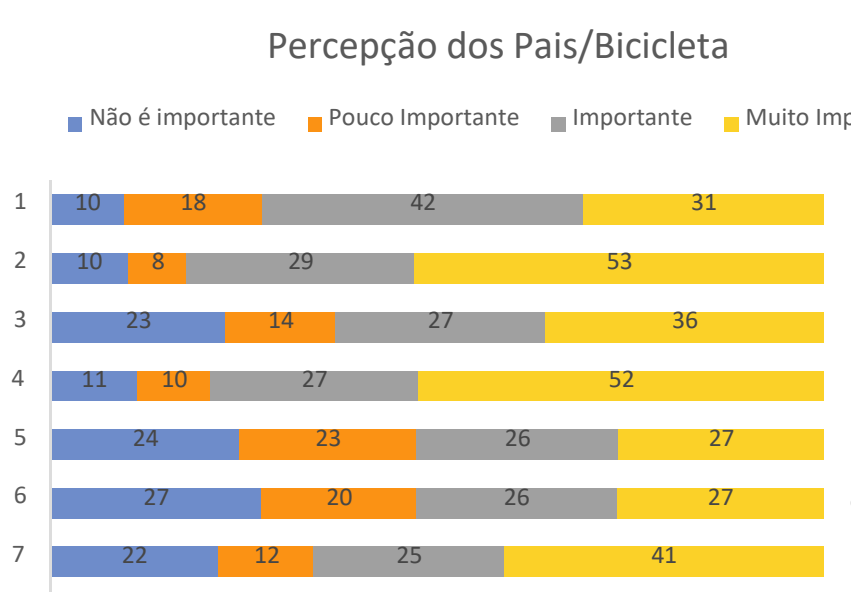

andar de bicicleta até a escola seria bom para a saúde do meu filho não me sinto a vontade de deixar meu filho ir de bicicleta por segurança a escola fica distante para que meu filho se desloque de bicicleta até ela meu bairro não é seguro para meu filho ir de bicicleta até a escola o clima dificulta para meu filho ir de bicicleta até a escola eu não me preocupo em incentivar meu filho a se deslocar de bicicleta ao sair de casa para ir a escola ainda está muito cedo e escuro

Figura 6.32 - Percepção dos pais quanto à importância das variáveis forma urbana moderadoras - mediadoras no deslocamento bicicleta/Goiânia

Quanto aos deslocamentos realizados por bicicleta $42 \%$ dos pais responderam ser "importante" para a saúde do filho utilizar tal modo nas viagens escolares. 53\% revelaram ser "muito importante" as questões de segurança de tráfego na utilização da bicicleta pela criança; $36 \%$ e $52 \%$ consideram "muito importante" questões ligadas a distância e segurança do bairro. $27 \%$ julgam o clima um fator "muito importante", no entanto, $22 \%$ acreditam que tal fator "não é importante". Quanto à educação do filho sobre o deslocamento por bicicleta, $27 \%$ responderam ser um fator "muito importante", entretanto, $27 \%$ consideram "não é importante" tal variável. $41 \%$ relatam ser "muito importante" o fato de ao sair de casa ainda estar muito cedo e escuro para se deslocar de bicicleta até a escola. 


\section{Percepção dos Pais/ônibus}

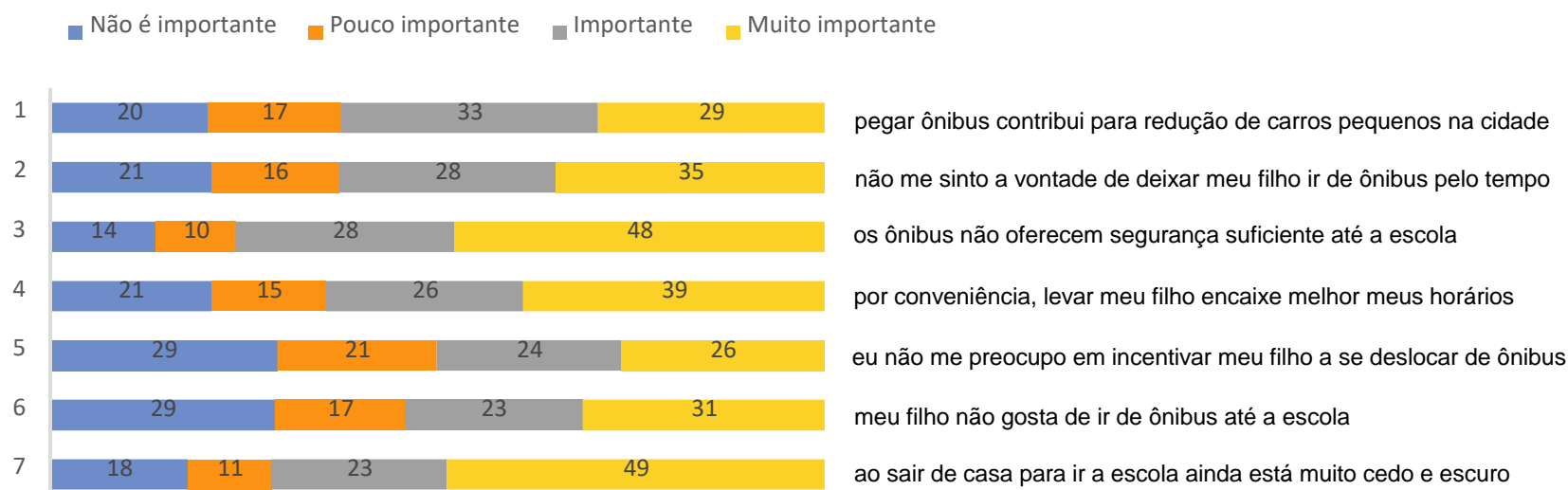

Figura 6.33 - Percepção dos pais quanto à importância das variáveis forma urbana moderadoras - mediadoras no deslocamento ônibus/Goiânia

Quanto ao deslocamento ser realizado por ônibus, 29\% dos entrevistados consideram ser "muito importante" o fato de estar contribuindo para diminuição do tráfego nas ruas, $33 \%$ consideram "importante" e $20 \%$ "não importante". Os pais julgam "muito importante" questões como tempo de deslocamento; segurança; conveniência para os deslocamentos realizados por ônibus. Quanto à educar seu filho sobre as viagens por ônibus $29 \%$ consideram "não importante". $49 \%$ relatam ser "muito importante" o fato de ao sair de casa ainda estar muito cedo e escuro para se deslocar d e ônibus até a escola. 


\subsection{RESULTADOS DO LEVANTAMENTO DA FORMA URBANA}

Tabela 6.1 - Variáveis da forma urbana - bairros de Goiânia pesquisados

\begin{tabular}{|c|c|c|c|c|c|c|c|c|c|c|c|c|c|c|c|c|c|}
\hline \multirow{2}{*}{ Setor } & \multirow{2}{*}{$\begin{array}{l}\text { Area do } \\
\text { Setor } \\
(\mathrm{km} 2) \\
\end{array}$} & \multirow{2}{*}{\begin{tabular}{|c|} 
Comp \\
total das \\
vias $(\mathrm{km})$ \\
\end{tabular}} & \multirow{2}{*}{\begin{tabular}{|c|}
$\begin{array}{c}\text { Densida } \\
\text { de de } \\
\text { vias }\end{array}$ \\
\end{tabular}} & \multirow{2}{*}{$\begin{array}{l}\text { Numero } \\
\text { total de } \\
\text { quadras } \\
\end{array}$} & \multirow{2}{*}{\begin{tabular}{|c|}
$\begin{array}{c}\text { Densidad } \\
\text { e de } \\
\text { quadras }\end{array}$ \\
\end{tabular}} & \multirow{2}{*}{\begin{tabular}{|c|} 
Comp \\
médio das \\
quadras \\
\end{tabular}} & \multirow{2}{*}{\begin{tabular}{|c|}
$\begin{array}{c}\text { Número de } \\
\text { interseções } \\
\text { em cruz }\end{array}$ \\
\end{tabular}} & \multirow{2}{*}{\begin{tabular}{|c|}
$\begin{array}{c}\text { Número de } \\
\text { interseçõe } \\
\text { sem T }\end{array}$ \\
\end{tabular}} & \multirow{2}{*}{\begin{tabular}{|c|}
$\begin{array}{c}\text { Número } \\
\text { total de } \\
\text { interseçõe }\end{array}$ \\
\end{tabular}} & \multirow{2}{*}{\begin{tabular}{|l} 
Densidad \\
e de \\
Interseccõ \\
\end{tabular}} & \multirow{2}{*}{ Conectividade } & \multirow{2}{*}{\begin{tabular}{|c|}
$\begin{array}{c}\text { Largura } \\
\text { média das } \\
\text { calçadas }\end{array}$ \\
\end{tabular}} & \multicolumn{2}{|c|}{ Linhas do Transporte Urbano } & \multicolumn{3}{|c|}{ Rotas Cicláveis (Km) } \\
\hline & & & & & & & & & & & & & Atendem & Margeiam & Ciclovia & ciclorrota & ciclofaixa \\
\hline Campinas & 2,120 & 52,065 & 24,559 & 204 & 96,226 & 0,426 & 151 & 49 & 200 & 94,34 & 0,76 & 3,15 & 25 & 2 & 0,00 & 0,00 & 0,00 \\
\hline Vila Paraiso & 0,150 & 2,423 & 16,153 & 13 & 86,667 & 0,407 & 6 & 5 & 11 & 73,33 & 0,55 & 2,50 & 0 & 9 & 0,00 & 0,00 & 0,00 \\
\hline Cidade Jardim & 2,787 & 73,404 & 26,338 & 70 & 25,117 & 0,557 & 54 & 50 & 104 & 37,32 & 0,52 & 3,40 & 14 & 10 & 0,00 & 0,00 & 0,00 \\
\hline Parque Ateneu & 1,859 & 43,841 & 23,583 & 234 & 125,874 & 0,337 & 76 & 204 & 280 & 150,62 & 0,27 & 2,08 & 10 & 0 & 0,00 & 0,00 & 0,00 \\
\hline Parque das Laranjein & 0,807 & 18,554 & 22,991 & 59 & 73,110 & 0,422 & 10 & 15 & 25 & 30,98 & 0,40 & 2,06 & 8 & 2 & 0,00 & 0,00 & 0,00 \\
\hline Jardim Novo Mundo & 6,494 & 153,044 & 23,567 & 188 & 28,950 & 0,457 & 123 & 183 & 306 & 47,12 & 0,40 & 3,00 & 33 & 3 & 0,00 & 0,00 & 0,00 \\
\hline Jardim Curitiba II & 3,530 & 63,900 & 18,102 & 192 & 54,391 & 0,433 & 87 & 143 & 230 & 65,16 & 0,38 & 2,50 & 2 & 8 & 0,00 & 0,00 & 0,00 \\
\hline Capuava & 1,627 & 31,103 & 19,117 & 71 & 43,639 & 0,554 & 63 & 40 & 103 & 63,31 & 0,61 & 2,00 & 22 & 1 & 0,00 & 0,00 & 0,00 \\
\hline Parque Tremendão & 1,959 & 30,748 & 15,696 & 109 & 55,641 & 0,548 & 30 & 106 & 136 & 69,42 & 0,22 & 2,30 & 4 & 2 & 0,00 & 0,00 & 0,00 \\
\hline Conjunto Itatiaia I & 0,918 & 20,503 & 22,334 & 53 & 57,734 & 0,465 & 34 & 96 & 130 & 141,61 & 0,26 & 2,49 & 13 & 0 & 0,00 & 0,00 & 0,00 \\
\hline Jardim Liberdade & 0,240 & 0,342 & 1,425 & 25 & 104,167 & 0,419 & 17 & 35 & 52 & 216,67 & 0,33 & 2,54 & 4 & 0 & 0,00 & 0,00 & 0,00 \\
\hline Setor Jaó & 3,008 & 54,132 & 17,996 & 154 & 51,197 & 0,416 & 133 & 163 & 296 & 98,40 & 0,45 & 2,76 & 2 & 6 & 0,00 & 0,00 & 0,00 \\
\hline Bairro Goià & 0,719 & 10,711 & 14,897 & 47 & 65,369 & 0,521 & 22 & 25 & 47 & 65,37 & 0,47 & 3,43 & 4 & 1 & 0,00 & 0,00 & 0,00 \\
\hline Carolina Parque & 0,359 & 6,515 & 18,148 & 23 & 64,067 & 0,508 & 3 & 27 & 30 & 83,57 & 0,10 & 2,70 & 2 & 0 & 0,00 & 0,00 & 0,00 \\
\hline Conjunto Vera Cruz & 5,118 & 110,267 & 21,545 & 215 & 42,009 & 0,512 & 30 & 215 & 245 & 47,87 & 0,12 & 2,60 & 15 & 2 & 0,00 & 0,00 & 0,00 \\
\hline Jardim Presidente & 1,461 & 38,470 & 26,331 & 88 & 60,233 & 0,554 & 42 & 59 & 101 & 69,13 & 0,42 & 2,50 & 12 & 1 & 0,00 & 0,00 & 0,00 \\
\hline Jardim Europa & 0,321 & 6,174 & 19,234 & 97 & 302,181 & 0,513 & 69 & 50 & 119 & 370,72 & 0,58 & 2,39 & 31 & 0 & 0,00 & 0,00 & 0,00 \\
\hline Setor Faiçalville & 3,773 & 85,157 & 22,570 & 179 & 47,442 & 0,514 & 63 & 167 & 230 & 60,96 & 0,27 & 2,90 & 6 & 9 & 0,00 & 0,00 & 0,00 \\
\hline Setor Pedro Ludovico & 3,222 & 77,821 & 24,153 & 156 & 48,417 & 0,573 & 103 & 86 & 189 & 58,66 & 0,54 & 4,10 & 27 & 1 & 1,40 & 1,1 & 0,00 \\
\hline Alto da Glória & 0,286 & 4,332 & 15,147 & 17 & 59,441 & 0,543 & 10 & 19 & 29 & 101,40 & 0,34 & 3,00 & 7 & 9 & 0,00 & 0,00 & 0,00 \\
\hline Setor Bueno & 4,160 & 113,830 & 27,363 & 166 & 39,904 & 0,586 & 128 & 64 & 192 & 46,15 & 0,67 & 3,00 & 28 & 3 & 0,00 & 0,00 & 0,00 \\
\hline
\end{tabular}

Fonte: Autora 


\section{- Comprimento Médio das quadras}

Segundo a literatura descrita no capitulo 2, comprimento de quadras aceitáveis para promover o deslocamento a pé variam de 0,10 a 0,20 km ou ainda menores. Quadras que possuem dimensões menores representam um aumento no número de interseções, resultando em um número maior de rotas e distâncias relativamente mais curtas de caminhadas. Conforme pode-se observar na Tabela 6.1, nenhum dos bairros estudados possuem essas dimensões de quadra. O menor valor foi de $0,337 \mathrm{~km}$ do bairro Parque Ateneu região Leste de Goiânia.

\section{- Densidade de quadras}

Um valor mais alto da densidade de quadras representa, um número maior de quadras no setor e, portanto, uma maior variedade de caminhos aos pedestres. Segundo Tabela 6.1 , os setores que tem os maiores valores de densidade de quadra são 302,181 ; 125,$874 ; 104,167$ correspondentes aos bairros Jardim Europa, Parque Ateneu e Jardim Liberdade respectivamente. O menor valor foi de 25,117 correspondente ao bairro Cidade Jardim.

\section{- Número de interseções em cruz e em T}

Um sistema viário na forma de grelha representa um maior número de intersecções em "cruz", ao contrário se um sistema viário não é em forma de grelha significa que o mesmo possui um número maior de intersecções em "T" e cul-de-sacs em sua configuração.

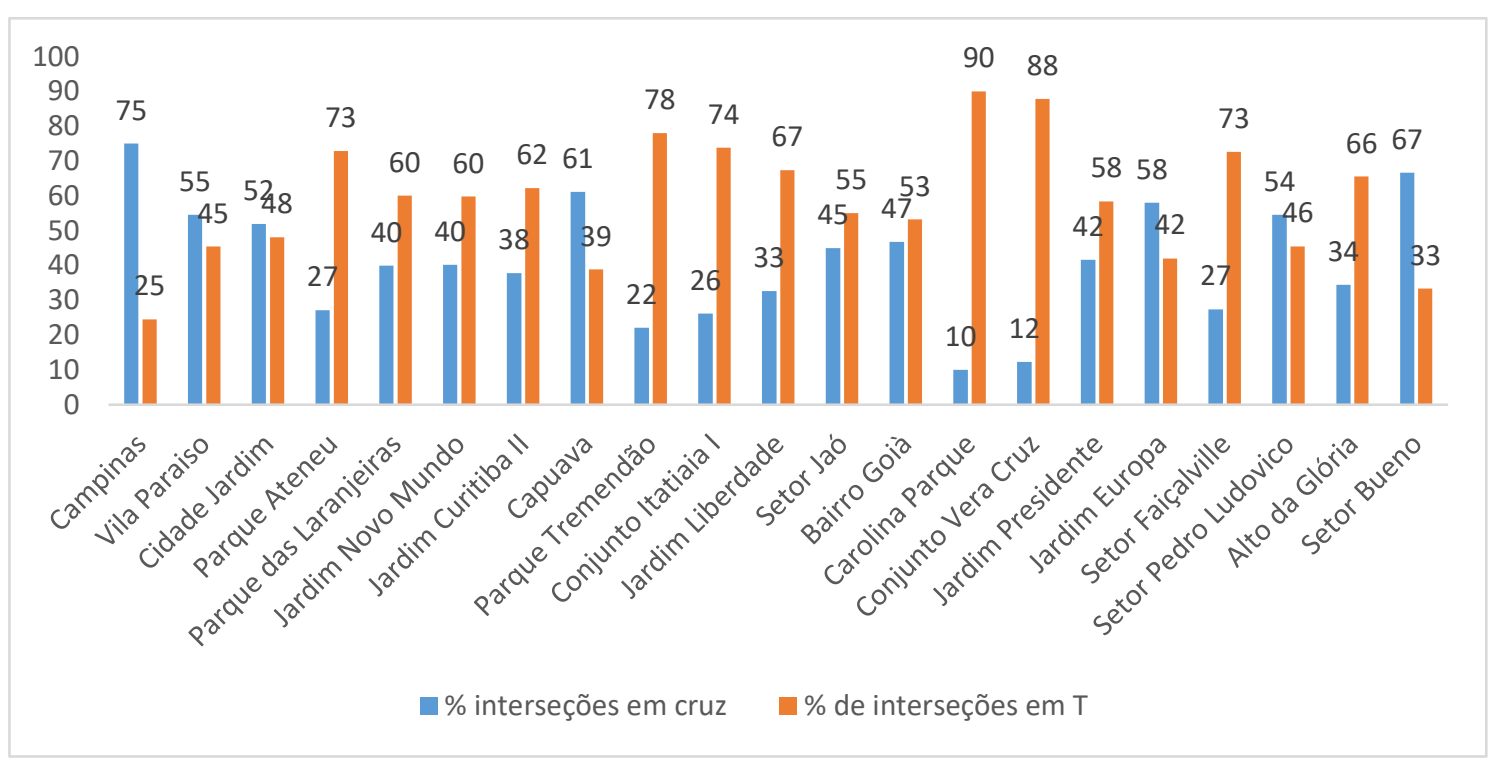

Figura 6.34 - \% de interseções em Cruz e T dos bairros pesquisados 
Pode-se observar na figura 6.34 que os setores que nasceram juntamente com a cidade de Goiânia, possuem o sistema viário em formato em cruz ou em "grelha" como é o caso de Campinas e Setor Bueno. O Parque Tremendão, tem sua configuração em forma de $\mathrm{T}$, criado em uma disputa por moradia entre população e governo, já citado anteriormente. Dos bairros sorteados apenas 33\% possuem sua configuração em forma de cruz e $67 \%$ em forma $T$.

Isso não indica que essa seja a configuração da cidade, ao contrário, Medeiros (2006) em seu trabalho apontou que as cidades brasileiras são predominantemente regulares e compostas por grelhas de padrões diversificados, o que remete a composição de grelhas, indício do padrão em colcha de retalhos. Conclui ainda que "(..), a cidade cresce, mas as partes não se articulam propriamente entre si ou com o todo. São como montagens pouco conectadas. Partes frouxas de um inteiro mambembe".

Ainda segundo Dias (2014), durante o crescimento da cidade de Goiânia não houve uma aparente preocupação quanto à conexão entre os bairros existentes e os que estavam sendo planejados e implantados, dessa forma, a malha é caracterizada pela associação de diversos padrões e desenhos, ainda que regulares, formando uma composição de grelhas.

\section{- Conectividade}

Esse índice pode variar entre 0 e 1 e quanto mais próximo de 1 estiver, representa uma configuração do sistema viário em forma de grelha. Muitos estudos indicam esse tipo de padrão viário como sendo o mais eficiente para incentivar as viagens a pé, pois apresentam uma maior variedade de opções de rotas.

Pode-se observar na Tabela 6.1 que os setores com o maior valor de conectividade é Campinas e Setor Bueno com valores 0,76 e 0,67 respectivamente. Os menores valores são Conjunto Vera Cruz e Parque Tremendão com valores 0,12 e 0,22 respectivamente.

\section{- Largura Média das calçadas}

Segundo dados levantados com auxílio de um mapa digital de Goiânia, pode-se observar na tabela que as calçadas dos 21 bairros residenciais estudados possuem largura superior a 1,5 m, valor este recomendado pela literatura e já inserido no Projeto 
de Lei das calçadas do município, a ser votado. Ressalta-se, no entanto, que esta medida foi retirada com a ajuda de um SIG, e apresenta apenas o valor total da largura da mesma, não sendo indicado: implantação de mobiliários urbanos, árvores, inclinação ou estado de conservação das mesmas.

\section{- Linhas do Transporte Urbano}

Representa uma medida da quantidade de linhas do transporte coletivo que atravessam e margeiam o bairro e fornece uma medida da acessibilidade ao serviço na área urbana. Uma maior cobertura do serviço implica maior acessibilidade e maior oferta de transporte coletivo.

Observando os dados da Tabela 6.1 os bairros que são melhor atendidos com as linhas do transporte público são: Jardim Novo Mundo, Jardim Europa, Setor Bueno, Setor Pedro Ludovico, Campinas com valores de linhas que atendem o bairro de 33, 31, 28, 27 e 25 respectivamente. Os menores valores são dos setores: Vila Paraiso, Jardim Curitiba II, Setor Jaó, Carolina Park e Parque Tremendão com valores 0, 2, 2, 2 e 4.

\section{- Ciclovia, ciclofaixa e ciclo rota}

Dentre os 21 bairros residenciais estudados apenas 1 possui ciclovia e ciclofaixa instaladas - Setor Pedro Ludovico, com medidas de 1,40 e 1,10 km respectivamente.

\subsection{RESULTADOS SOBRE AS ESCOLHAS DOS DIFERENTES MODOS}

Os resultados obtidos através do processamento do modelo multinomial construído para o problema proposto, como citado no Capítulo 5, se resumiu nas seguintes etapas:

1. Montar as equações da função utilidade;

2. validar o modelo;

3. analisar as variáveis que apresentam influência positiva ou negativa na escolha dos indivíduos

4. avaliar a razão de chance (odds ratio) para as variáveis que apresentam uma significância satisfatória e,

5. analisar as probabilidades de escolha. 
Tabela 6.2 - Resultados do processamento completo - R-Studio $\AA$

\begin{tabular}{|c|c|c|c|c|c|}
\hline \multirow{2}{*}{ (Intercept): 1} & \multirow{2}{*}{$\begin{array}{r}\text { Estimate } \\
8.24614\end{array}$} & \multicolumn{4}{|c|}{ Std. Error z-value $\operatorname{Pr}(>|z|)$} \\
\hline & & 1.50871 & 5.466 & $4.61 e-08$ & $\star \star \star$ \\
\hline (Intercept) $: 2$ & 11.07325 & 1.48722 & 7.446 & $9.65 e-14$ & $\star \star \star$ \\
\hline (Intercept) $: 3$ & 6.97143 & 2.17163 & 3.210 & 0.001326 & $\star \star$ \\
\hline V3Municipal:1 & -0.43980 & 0.42455 & -1.036 & 0.300239 & \\
\hline V3Municipal:2 & -0.87742 & 0.39850 & -2.202 & 0.027677 & * \\
\hline V3Municipal:3 & 0.06779 & 0.65728 & 0.103 & 0.917857 & \\
\hline V3Particular:1 & 2.35639 & 0.51168 & 4.605 & $4.12 e-06$ & 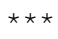 \\
\hline V3Particular:2 & 0.11455 & 0.51557 & 0.222 & 0.824174 & \\
\hline V3Particular:3 & -0.96611 & 1.18346 & -0.816 & 0.414301 & \\
\hline V180 aluno vai sozinho:1 & -4.49721 & 0.59155 & -7.602 & $2.91 e-14$ & $\star \star \star$ \\
\hline V180 aluno vai sozinho:2 & -2.93664 & 0.58140 & -5.051 & $4.40 e-07$ & $\star \star \star$ \\
\hline V180 aluno vai sozinho:3 & -2.69768 & 0.71013 & -3.799 & 0.000145 & $\star \star \star$ \\
\hline V18Pai:1 & 0.41732 & 0.90384 & 0.462 & 0.644284 & \\
\hline V18Pai:2 & -0.99134 & 0.92655 & -1.070 & 0.284652 & \\
\hline V18Pai:3 & -2.00785 & 1.39215 & -1.442 & 0.149228 & \\
\hline V18Um outro adulto da família:1 & -1.10884 & 0.73027 & -1.518 & 0.128913 & \\
\hline V18Um outro adulto da família:2 & -1.61878 & 0.74888 & -2.162 & 0.030648 & * \\
\hline V18Um outro adulto da família: 3 & -1.93905 & 0.98879 & -1.961 & 0.049876 & * \\
\hline V18Um outro adulto que não é da família:1 & -1.19947 & 0.70584 & -1.699 & 0.089252 & . \\
\hline V18Um outro adulto que não é da família:2 & -3.13519 & 0.77274 & -4.057 & $4.97 e-05$ & $\star \star \star$ \\
\hline V18Um outro adulto que não é da família:3 & -16.78393 & 576.65607 & -0.029 & 0.976780 & \\
\hline V18Vizinhos:1 & -2.97845 & 0.77488 & -3.844 & 0.000121 & $\star \star \star$ \\
\hline V18Vizinhos:2 & -1.88058 & 0.76513 & -2.458 & 0.013977 & * \\
\hline V18Vizinhos: 3 & -2.51332 & 1.27678 & -1.968 & 0.049013 & * \\
\hline V47sim: 1 & -0.10084 & 0.34493 & -0.292 & 0.770030 & \\
\hline V47sim:2 & -1.77261 & 0.34193 & -5.184 & $2.17 e-07$ & $\star \star \star$ \\
\hline V47sim: 3 & -0.98730 & 0.56804 & -1.738 & 0.082197 & . \\
\hline V55sim: 1 & -0.85760 & 0.31281 & -2.742 & 0.006113 & $\star \star$ \\
\hline V55sim:2 & -0.84831 & 0.30119 & -2.817 & 0.004855 & $\star \star$ \\
\hline V55sim:3 & -0.62088 & 0.49883 & -1.245 & 0.213253 & \\
\hline V91Muito importante:1 & -0.29140 & 0.37746 & -0.772 & 0.440114 & \\
\hline V91Muito importante: 2 & -0.10873 & 0.36602 & -0.297 & 0.766428 & \\
\hline V91Muito importante: 3 & -1.12967 & 0.58641 & -1.926 & 0.054052 & . \\
\hline V91Não é importante:1 & 1.56100 & 0.51885 & 3.009 & 0.002625 & $\star \star$ \\
\hline V91Não é importante:2 & 2.12097 & 0.49952 & 4.246 & $2.18 e-05$ & $\star \star \star$ \\
\hline V91Não é importante: 3 & 0.75417 & 0.71449 & 1.056 & 0.291176 & \\
\hline V91Pouco importante: 1 & 2.16347 & 0.71378 & 3.031 & 0.002438 & $\star \star$ \\
\hline V91Pouco importante:2 & 2.52486 & 0.69821 & 3.616 & 0.000299 & $\star \star \star$ \\
\hline V91Pouco importante:3 & 0.86751 & 1.02791 & 0.844 & 0.398696 & \\
\hline V100Muito importante: 1 & -0.86328 & 0.47245 & -1.827 & 0.067665 & . \\
\hline V100Muito importante: 2 & -0.58182 & 0.46022 & -1.264 & 0.206157 & \\
\hline V100Muito importante: 3 & 0.22234 & 0.67168 & 0.331 & 0.740635 & \\
\hline V100Não é importante:1 & -2.02250 & 0.49756 & -4.065 & $4.81 e-05$ & $\star \star \star$ \\
\hline V100Não é importante:2 & -2.18988 & 0.48918 & -4.477 & $7.58 e-06$ & $\star \star \star$ \\
\hline V100Não é importante: 3 & -1.40168 & 0.76116 & -1.842 & 0.065548 & . \\
\hline V100Pouco importante: 1 & -1.62564 & 0.51430 & -3.161 & 0.001573 & $\star \star$ \\
\hline V100Pouco importante: 2 & -1.69444 & 0.50178 & -3.377 & 0.000733 & $\star \star \star$ \\
\hline V100Pouco importante: 3 & -1.49173 & 0.84915 & -1.757 & 0.078964 & . \\
\hline $\mathrm{V} 110: 1$ & -0.17666 & 0.05201 & -3.397 & 0.000682 & $\star \star \star$ \\
\hline V110:2 & -0.28262 & 0.05113 & -5.528 & $3.24 e-08$ & $\star \star \star$ \\
\hline$V 110: 3$ & -0.24131 & 0.08334 & -2.896 & 0.003785 & $\star \star$ \\
\hline $\mathrm{V} 121: 1$ & 0.07135 & 0.05803 & 1.230 & 0.218870 & \\
\hline $\mathrm{V} 121: 2$ & 0.10169 & 0.05704 & 1.783 & 0.074626 & . \\
\hline V121:3 & 0.18795 & 0.07558 & 2.487 & 0.012887 & * \\
\hline
\end{tabular}

A tabela 6.2 apresenta os resultados do processamento do modelo completo envolvendo todas as variáveis identificadas com significância no modelo. A significância foi observada avaliando os valores de probabilidades $\operatorname{Pr}(>|z|)$, também conhecido como P_valor. São considerados significativos valores de $\operatorname{Pr}(>|z|)<0,1$. O software R-Studio® identifica com um asterisco os valores que atendem a esta relação. Um asterisco já 
identifica significância da variável, no entanto, quanto maior o número de asterisco, maior significância tem a variável no modelo.

Tabela 6.3 - Variáveis do modelo completo - R-Studio®

\begin{tabular}{|c|c|c|}
\hline Variável & Item do Questionário & Respostas Possíveis \\
\hline V3 & $\begin{array}{l}\text { Relacionada à rede ou âmbito da escola da } \\
\text { criança }\end{array}$ & Municipal - Particular - Estadual \\
\hline V18 & $\begin{array}{l}\text { Relacionada ao tipo de Acompanhante que } \\
\text { conduz a criança até a escola }\end{array}$ & $\begin{array}{l}\text { Mãe - Pai - Adulto da família } \\
\text { Adulto que não é da família - } \\
\text { Vizinhos - Vai sozinho }\end{array}$ \\
\hline V47 & $\begin{array}{l}\text { Relacionada à distância da residência à escola e } \\
\text { a escolha do modal bicicleta }\end{array}$ & $\begin{array}{l}\text { Sim } \\
\text { Não }\end{array}$ \\
\hline V55 & $\begin{array}{l}\text { Relacionada às informações das linhas de partida } \\
\text { e chegada de ônibus }\end{array}$ & $\begin{array}{l}\text { Sim } \\
\text { Não }\end{array}$ \\
\hline V91 & $\begin{array}{l}\text { Relacionada à distância da residência à escola e } \\
\text { a escolha do modal caminhamento }\end{array}$ & $\begin{array}{l}\text { Não é importante - Pouco importante - } \\
\text { Importante - Muito Importante }\end{array}$ \\
\hline V100 & $\begin{array}{l}\text { Relacionada ao incentivo à criança em ir a pé até } \\
\text { a escola }\end{array}$ & $\begin{array}{l}\text { Não é importante - Pouco importante - } \\
\text { Importante - Muito Importante }\end{array}$ \\
\hline V110 & Relacionada à densidade de vias & valor \\
\hline V121 & $\begin{array}{l}\text { Relacionada às linhas de transporte público que } \\
\text { margeiam o setor }\end{array}$ & valor \\
\hline
\end{tabular}

$\mathrm{Na}$ tabela 6.3 é apresentado um resumo das variáveis apresentadas na tabela final do programa R-Studio®. Dentre as 123 variáveis que abasteceram o modelo de decisão apenas 8 apresentaram significância e dessa forma, influenciam a decisão dos pais quanto a escolha do modo de transporte até a escola.

Além do processamento global de todas as variáveis em um único modelo, foi adotado o processo de forma independente de cada variável da forma urbana e que apresentaram respostas com significância. As variáveis independentes estudadas foram as seguintes:

Tabela 6.4 - Variáveis da forma urbana avaliadas de maneira independente R-Studio ${ }^{\circledR}$

\begin{tabular}{|l|l|l|}
\hline V108 - área do setor & V109 - Comp. Das Vias & V110 - Densidade de Vias \\
\hline V111 - Núm. De Quadras & V112 - Densidade Quadras & V113 - Comp. De Quadras \\
\hline V114 - Interseções em Cruz & V115 - Interseções em T & V116 - Núm. Interseções \\
\hline V117 - Densidade de interseções & V118 - Conectividade & V119 - Largura das Calçadas \\
\hline V120 - Linhas de ônibus Atendem & V121 - Linhas de ônibus margeiam & \\
\hline
\end{tabular}


Os resultados do processamento independente, para cada variável estão organizados na tabela 6.4 onde, para cada variável com significância (V108 á V111 e V118 á V121), encontra-se uma função de utilidade relacionada aos modos de transporte.

Tabela 6.5 - Resultados do processamento independente - R-Studio®

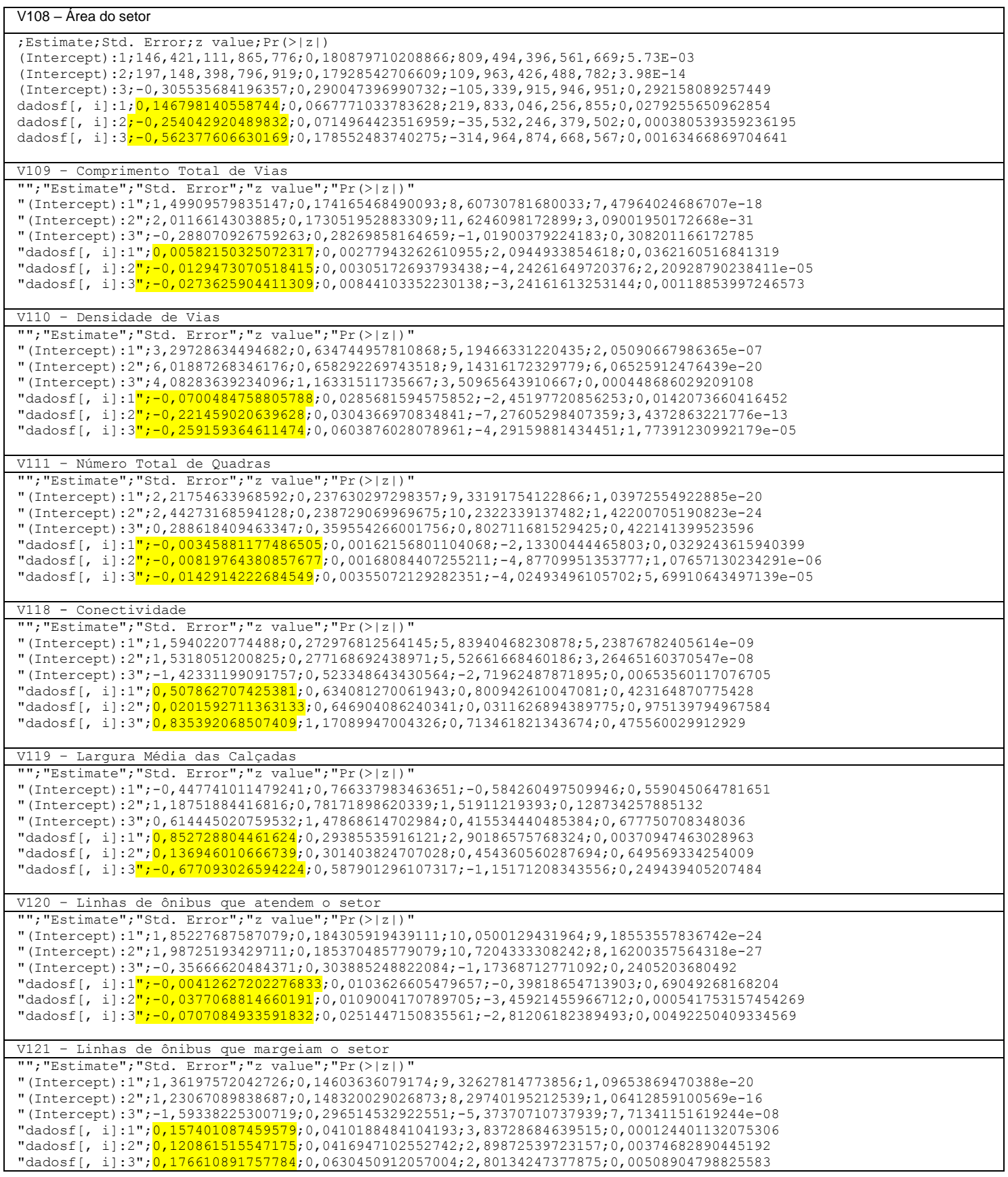

As variáveis da forma urbana relacionadas a ciclovia, ciclofaixa e ciclorota não foram analisadas, pois apresentaram baixa significância. Esse fato pode ser explicado devido os dados relacionados a essas variáveis, na maior parte, tem o valor nulo. Dessa forma os valores dessas variáveis foram negligenciados quando na montagem da função utilidade. Na tabela 6.5 anterior destacam-se às variáveis com maior significância nas 
respostas e os respectivos estimadores (destacados em amarelo), utilizados para a avaliação da razão de chance, $O R$, identificada na estatística como "odds ratio":

$$
O R=\frac{\frac{\left(\frac{e^{\beta_{0}+\beta_{1}}}{1+e^{\beta_{0}+\beta_{1}}}\right)}{\left(\frac{1}{1+e^{\beta_{0}+\beta_{1}}}\right)}}{\frac{\left(\frac{e^{\beta_{0}}}{1+e^{\beta_{0}}}\right)}{\frac{1}{1+e^{\beta_{0}}}}}=\frac{e^{\beta_{0}+\beta_{1}}}{e^{\beta_{0}}}=e^{\left(\beta_{0}+\beta_{1}\right)-\beta_{0}}=e^{\beta_{1}}
$$

\section{- Resultados do Processamento do Modelo Completo}

Com relação à rede de ensino onde a criança está matriculada, os resultados demonstram para variável V3 (rede) que:

- O aluno ser da rede municipal diminui em $36 \%$ a chance de usar outros meios de transporte em relação ao aluno da rede estadual ( $\beta=-0,43980 ;$ OR $=-36 \%)$;

- O aluno ser da rede municipal diminui em 58\% a chance de ir a pé para a escola em relação ao aluno da rede estadual $(\beta=-0,87742$; OR $=-58 \%)$;

- O aluno ser da rede municipal aumenta em $7 \%$ a chance de ir de bicicleta para a escola em relação ao aluno da rede estadual $(\beta=-0,06779$; OR $=-58 \%)$;

- O aluno ser da rede particular aumenta em 10 vezes a chance de usar outros meios de transporte em relação ao aluno da rede estadual $(\beta=2,35639$; OR $=10 x)$;

- O aluno ser da rede particular aumenta em 12\% a chance de ir a pé para a escola em relação ao aluno da rede estadual $(\beta=0,11455$; OR $=12 \%)$;

- O aluno ser da rede particular diminui em $62 \%$ a chance de ir de bicicleta para a escola em relação ao aluno da rede estadual $(\beta=-0,96611 ; \mathrm{OR}=-62 \%)$;

Com relação à variável V18, que representa o indivíduo que acompanha a criança na volta da escola, utilizou-se como referência a mãe da criança e os resultados obtidos no modelo completo apontam que:

- A chance do aluno ir sozinho na volta da escola utilizando outros meios de transporte diminui em 100\% em relação aos alunos acompanhados pela mãe $(\beta=-4,49721$; OR = $-100 \%)$;

- A chance do aluno ir sozinho a pé na volta da escola diminui em 95\% em relação aos alunos acompanhados pela mãe $(\beta=-2,93664 ;$ OR = -95\%); 
- A chance do aluno ir sozinho utilizando bicicleta na volta da escola diminui em 93\% em relação aos alunos acompanhados pela mãe $(\beta=-2,69768$; OR $=-93 \%)$;

- A chance do aluno ir acompanhado do pai na volta da escola utilizando outros meios de transporte aumenta em $52 \%$ em relação aos alunos acompanhados pela mãe $(\beta=0,41732 ;$ OR $=52 \%)$;

- A chance do aluno ir acompanhado do pai a pé na volta da escola diminui em $63 \%$ em relação aos alunos acompanhados pela mãe $(\beta=-0,99134$; OR $=-63 \%)$;

- A chance do aluno ir acompanhado do pai de bicicleta na volta da escola diminui em $87 \%$ em relação aos alunos acompanhados pela mãe $(\beta=-2,00785 ; O R=-87 \%)$;

- A chance do aluno ir acompanhado de um adulto da família na volta da escola utilizando outros meios de transporte diminui em $67 \%$ em relação aos alunos acompanhados pela mãe $(\beta=-1,10884 ; O R=-67 \%)$;

- A chance do aluno ir acompanhado de um adulto da família na volta da escola a pé diminui em $80 \%$ em relação aos alunos acompanhados pela mãe $(\beta=-1,61878$; OR = $80 \%)$;

- A chance do aluno ir acompanhado de um adulto da família na volta da escola utilizando a bicicleta diminui em $86 \%$ em relação aos alunos acompanhados pela mãe $(\beta=-1,93905 ;$ OR $=-86 \%)$;

- A chance do aluno ir acompanhado de um adulto que não é da família na volta da escola utilizando outros meios de transporte diminui em $70 \%$ em relação aos alunos acompanhados pela mãe $(\beta=-1,19947 ;$ OR $=-70 \%)$;

- A chance do aluno ir acompanhado de um adulto que não é da família na volta da escola a pé diminui em $96 \%$ em relação aos alunos acompanhados pela mãe ( $\beta=-$ 3,$13519 ;$ OR $=-96 \%$ );

- A chance do aluno ir acompanhado de um adulto que não é da família na volta da escola utilizando a bicicleta diminui em $100 \%$ em relação aos alunos acompanhados pela mãe $(\beta=-16,78393 ; O R=-100 \%)$;

- A chance do aluno ir acompanhado de um vizinho na volta da escola utilizando outros meios de transporte diminui em 95\% em relação aos alunos acompanhados pela mãe $(\beta=-2,97845 ;$ OR $=-95 \%)$;

- A chance do aluno ir acompanhado de um vizinho na volta da escola a pé diminui em $85 \%$ em relação aos alunos acompanhados pela mãe $(\beta=-1,88058$; OR $=-85 \%)$;

- A chance do aluno ir acompanhado de um vizinho na volta da escola utilizando a bicicleta diminui em $92 \%$ em relação aos alunos acompanhados pela mãe ( $\beta=-2,51332$ ; OR = -92\%); 
A variável V47 que relaciona a se a distância da casa à escola é longa para ir de bicicleta, as respostas do modelo numérico indicam que:

- A chance do aluno que utiliza outros meios de transporte declarar que sua casa é longe demais da escola para ir de bicicleta diminui em $10 \%$ em relação aos alunos que declaram que a escola não é longe ( $\beta=-0,10084$; OR = -10\%);

- A chance do aluno que vai a pé declarar que sua casa é longe demais da escola para ir de bicicleta diminui em $8 \%$ em relação aos alunos que declaram que a escola não é longe $(\beta=-1,77261 ; O R=-8 \%)$;

- A chance do aluno que vai de bicicleta declarar que sua casa é longe demais da escola para ir de bicicleta diminui em $63 \%$ em relação aos alunos que declaram que a escola não é longe $(\beta=-0,98730 ; \mathrm{OR}=-63 \%)$.

As respostas da variável V55 que questiona se existem informações sobre linhas e horários do transporte público urbano nas paradas e terminais, apontam que:

- A chance do aluno que utiliza outros meios de transporte declarar que existem informações sobre linhas e horários de ônibus diminui em $57 \%$ em relação aos alunos que declaram que não existem informações de linhas e horários $(\beta=-0,85760 ; O R=-$ $57 \%)$;

- A chance do aluno que vai a pé declarar que existem informações sobre linhas e horários de ônibus diminui em $57 \%$ em relação aos alunos que declaram que não existem informações de linhas e horários ( $\beta=-0,84831$; OR = -57\%);

- A chance do aluno que utiliza a bicicleta declarar que existem informações sobre linhas e horários de ônibus diminui em $46 \%$ em relação aos alunos que declaram não existem informações de linhas e horários $(\beta=-0,62088$; OR = -46\%).

No que tange ao questionamento se a escola fica longe para que a criança se desloque a pé, controlada no modelo pela variável V91, às respostas indicaram que:

- A chance do aluno que utiliza outros meios de transporte declarar que é muito importante que a escola fica longe para se deslocar a pé diminui em $25 \%$ em relação aos alunos que declaram que é importante $(\beta=-0,29140 ; O R=-25 \%)$;

- A chance do aluno que vai a pé declarar que é muito importante que a escola fica longe para se deslocar a pé diminui em $10 \%$ em relação aos alunos que declaram que é importante $(\beta=-0,10873$; OR $=-10 \%)$;

- A chance do aluno que utiliza bicicleta declarar que é muito importante que a escola fica longe para se deslocar a pé diminui em $68 \%$ em relação aos alunos que declaram que é importante $(\beta=-1,12967 ; \mathrm{OR}=-68 \%)$; 
- A chance do aluno que utiliza outros meios de transporte declarar que não é importante que a escola fica longe para se deslocar a pé aumenta em 5 vezes em relação aos alunos que declaram que é importante $(\beta=1,56100$; OR $=5 x)$;

- A chance do aluno que vai a pé para escola declarar que não é importante que a escola fica longe para se deslocar a pé aumenta em 8 vezes em relação aos alunos que declaram que é importante $(\beta=2,12097$; OR = 8x);

- A chance do aluno que utiliza a bicicleta declarar que não é importante que a escola fica longe para se deslocar a pé aumenta em 2 vezes em relação aos alunos que declaram que é importante $(\beta=0,75417 ; O R=2 x)$.

- A chance do aluno que utiliza outros meios de transporte declarar que é pouco importante que a escola fica longe para se deslocar a pé aumenta em 9 vezes em relação aos alunos que declaram que é importante $(\beta=2,16347$; OR $=9 x)$;

- A chance do aluno que vai a pé declarar que é pouco importante que a escola fica longe para se deslocar a pé aumenta em 12 vezes em relação aos alunos que declaram que é importante $(\beta=2,52486 ; O R=12 x)$;

- A chance do aluno que utiliza a bicicleta declarar que é pouco importante que a escola fica longe para se deslocar a pé aumenta em 2 vezes em relação aos alunos que declaram que é importante $(\beta=0,86751 ; O R=2 x)$;

Sobre a preocupação da família em incentivar o filho a ir a pé até a escola, controlada pela variável V100, as respostas obtidas foram as seguintes:

- A chance da família que utiliza outros meios de transporte declarar que é muito importante incentivar que o filho vá a pé para a escola diminui em $58 \%$ em relação às famílias que declaram que é importante ( $\beta=-0,86328$; OR $=-58 \%)$;

- A chance da família que vai a pé declarar que é muito importante incentivar que o filho vá a pé para a escola diminui em $44 \%$ em relação às famílias que declaram que é importante $(\beta=-0,58182$; OR $=-44 \%)$;

- A chance da família que utiliza a bicicleta declarar que é muito importante incentivar que o filho vá a pé para a escola aumenta em $25 \%$ em relação às famílias que declaram que é importante $(\beta=0,22234 ; \mathrm{OR}=25 \%)$;

- A chance da família que utiliza outros meios de transporte declarar que não é importante incentivar que o filho vá a pé para a escola diminui em $87 \%$ em relação às famílias que declaram que é importante ( $\beta=-2,02250$; OR = -87\%);

- A chance da família que vai a pé declarar que não é importante incentivar que o filho vá a pé para a escola diminui em $89 \%$ em relação às famílias que declaram que é importante $(\beta=-2,18988 ;$ OR $=-89 \%)$; 
- A chance da família que utiliza a bicicleta declarar que não é importante incentivar que o filho vá a pé para a escola diminui em $75 \%$ em relação às famílias que declaram que é importante ( $\beta=-1,40168$; OR = -75\%);

- A chance da família que utiliza outros meios de transporte declarar que é pouco importante incentivar que o filho vá a pé para a escola diminui em $80 \%$ em relação às famílias que declaram que é importante ( $\beta=-1,62564 ; \mathrm{OR}=-80 \%)$;

- A chance da família que vai a pé declarar que é pouco importante incentivar que o filho vá a pé para a escola diminui em $81 \%$ em relação às famílias que declaram que é importante $(\beta=-1,69444 ;$ OR $=-81 \%)$;

- A chance da família que utiliza a bicicleta declarar que é pouco importante incentivar que o filho vá a pé para a escola diminui em $78 \%$ em relação às famílias que declaram que é importante $(\beta=-1,49173 ; \mathrm{OR}=-78 \%)$;

A variável V110 que monitora a densidade de vias no modelo completo apresentou as respostas a seguir:

- A cada unidade que aumenta a densidade de vias diminui em $16 \%$ as chances de se utilizar outros modos de transporte $(\beta=-0,17666 ; \mathrm{OR}=-16 \%)$;

- A cada unidade que aumenta a densidade de vias diminui em $25 \%$ as chances de se ir a pé para a escola $(\beta=-28262 ;$ OR $=-25 \%)$;

- A cada unidade que aumenta a densidade de vias diminui em $21 \%$ as chances de se ir de bicicleta para a escola $(\beta=-0,24131 ; O R=-21 \%)$.

A influência das linhas de transporte público que margeiam o setor apresentou significância e é representada no modelo pela variável V121 onde encontrou-se as seguintes respostas:

- A cada unidade que aumentam as linhas do transporte público que margeiam o setor aumenta em $7 \%$ as chances de se utilizar outros modos de transporte $(\beta=0,07135$; OR $=7 \%$;

- A cada unidade que aumentam as linhas do transporte público que margeiam o setor aumenta em $11 \%$ as chances de se ir a pé para a escola $(\beta=0,10169 ;$ OR $=11 \%)$;

- A cada unidade que aumentam as linhas do transporte público que margeiam o setor aumenta em $21 \%$ as chances de se utilizar a bicicleta para ir a escola $(\beta=0,18795$; OR $=21 \%$ ). 


\section{- Resultados do Processamento do Modelo Por Variável Independente}

O monitoramento de cada variável independente e relacionada com a forma urbana se faz necessário pois permite mensurar a relevância das variáveis no problema em estudo. No que se refere a área do setor, monitorada pela variável V108, apresentou as seguintes respostas:

- A cada unidade que aumenta na área do setor, aumenta em $16 \%$ as chances de se utilizar outros modos de transporte $(\beta=0,1467$; OR $=16 \%)$;

- A cada unidade que aumenta na área do setor, diminui em $22 \%$ as chances a criança ir a pé para a escola $(\beta=-0,25404 ; \mathrm{OR}=-22 \%)$;

- A cada unidade que aumenta na área do setor, diminui em $43 \%$ as chances de se utilizar a bicicleta $(\beta=-0,5623 ;$ OR $=-43 \%)$;

Ao avaliar o comprimento total das vias que foi monitorada pela variável V109, as respostas indicaram que:

- A cada unidade que aumenta no comprimento total de vias, aumenta em 0,5\% as chances de se utilizar outros modos de transporte $(\beta=-0,005821 ; \mathrm{OR}=0,5 \%)$;

- A cada unidade que aumenta no comprimento total de vias, diminui em $1 \%$ as chances de ir a pé para a escola $(\beta=-0,012947 ; O R=-1 \%)$;

- A cada unidade que aumenta no comprimento total de vias, diminui em $3 \%$ as chances de se utilizar a bicicleta $(\beta=-0,027362 ;$ OR $=-3 \%)$;

A densidade de vias, outra variável relacionada à forma urbana e monitorada pela variável V110, influenciou no modelo numérico da seguinte forma:

- A cada unidade que aumenta na densidade de vias, diminui em $7 \%$ as chances de se utilizar outros modos de transporte $(\beta=-0,0700484 ; \mathrm{OR}=-7 \%)$;

- A cada unidade que aumenta na densidade de vias, diminui em $20 \%$ as chances de ir a pé para a escola $(\beta=-0,2214590 ; \mathrm{OR}=-20 \%)$;

- A cada unidade que aumenta na densidade vias, diminui em $22 \%$ as chances de se utilizar a bicicleta $(\beta=-0,2591593 ;$ OR $=-22 \%)$.

O número total de quadras do setor marcou sua influência através da variável V111 que apontou os seguintes resultados:

- A cada unidade que aumenta número total de quadras, diminui em $0,3 \%$ as chances de se utilizar outros modos de transporte $(\beta=-0,0034588 ; O R=-0,3 \%)$; 
- A cada unidade que aumenta número total de quadras, diminui em 0,8\% as chances de ir a pé para a escola $(\beta=-0,0081976 ;$ OR $=-0,8 \%)$;

- A cada unidade que aumenta número total de quadras, diminui em 1,5\% as chances de se utilizar a bicicleta $(\beta=-0,0142914 ;$ OR $=-1,5 \%)$.

A densidade de quadras (variável V112) apresentou baixa significância ao modelo e na escolha dos modos. Os resultados obtidos foram os seguintes:

- A cada unidade que aumenta na densidade de quadras, tem $0 \%$ as chances de se utilizar outros modos de transporte $(\beta=0,0001261 ; \mathrm{OR}=0 \%)$;

- A cada unidade que aumenta na densidade de quadras, aumenta em 0,14\% as chances de ir a pé para a escola $(\beta=0,0014512$; OR $=0,14 \%)$;

- A cada unidade que aumenta na densidade de quadras, aumenta em 0,14\% as chances de se utilizar a bicicleta $(\beta=-0,0015183$; OR $=0,14 \%)$.

Foram obtidos resultados com relação a conectividade (variável V118). As chances para cada modal são as seguintes:

- A cada unidade que aumenta na conectividade, tem 0,6\% as chances de se utilizar outros modos de transporte $(\beta=0,507862 ; \mathrm{OR}=0,6 \%)$;

- A cada unidade que aumenta na conectividade, tem $2 \%$ as chances de se ir a pé para a escola $(\beta=-0,020159 ;$ OR $=2 \%)$;

- A cada unidade que aumenta na conectividade, tem 2 vezes as chances de se utilizar a bicicleta $(\beta=-0,835392 ;$ OR $=2 x)$.

A largura média das calçadas avaliada pela variável V119 no modelo numérico apresentou sua influência através dos seguintes resultados:

- A cada unidade que aumenta na largura média das calçadas, tem 2 vezes as chances de se utilizar outros modos de transporte $(\beta=0,8527288$; OR $=2 x)$;

- A cada unidade que aumenta na largura média das calçadas, tem $15 \%$ as chances de se ir a pé para a escola $(\beta=0,1369460 ; \mathrm{OR}=15 \%)$;

A cada unidade que aumenta na largura média das calçadas, reduz em $50 \%$ as chances de se utilizar a bicicleta $(\beta=-0,6770930 ; O R=-50 \%)$.

Foram monitoradas as linhas de transporte público que atendem o setor (variável V120) e as que margeiam (variável V121). Nas linhas que atendem os resultados encontrados foram os seguintes: 
- A cada unidade que aumenta nas linhas de transporte público, diminui em 0,4\% as chances de se utilizar outros modos de transporte $(\beta=-0,00412627 ; \mathrm{OR}=-0,4 \%)$;

- A cada unidade que aumenta nas linhas de transporte público, diminui em $4 \%$ as chances de ir a pé para a escola $(\beta=-0,0377068 ; \mathrm{OR}=-4 \%)$;

- A cada unidade que aumenta nas linhas de transporte público, diminui em $7 \%$ as chances de se utilizar a bicicleta $(\beta=-0,0707084 ;$ OR $=-7 \%)$.

Nas linhas de transporte público que margeiam o setor, variável $\mathrm{V} 121$, têm-se o seguinte:

- A cada unidade que aumenta Nas linhas de TP que margeiam, aumenta em 17\% as chances de se utilizar outros modos de transporte $(\beta=0,15740108 ; \mathrm{OR}=17 \%)$;

- A cada unidade que aumenta Nas linhas de TP que margeiam, aumenta em $13 \%$ as chances de ir a pé para a escola $(\beta=0,1208615$; OR $=13 \%)$;

- A cada unidade que aumenta Nas linhas de TP que margeiam, aumenta em 19\% as chances de se utilizar a bicicleta $(\beta=-0,17661089$; OR $=19 \%)$.

\subsection{TÓPICOS CONCLUSIVOS}

Os resultados do modelo com relação às probabilidades que apontam o modo de transporte escolhido pelo indivíduo, na condução da criança que estuda no ensino fundamental, até a escola, para a cidade de Goiânia, podem ser visualizados na figura 6.34 .

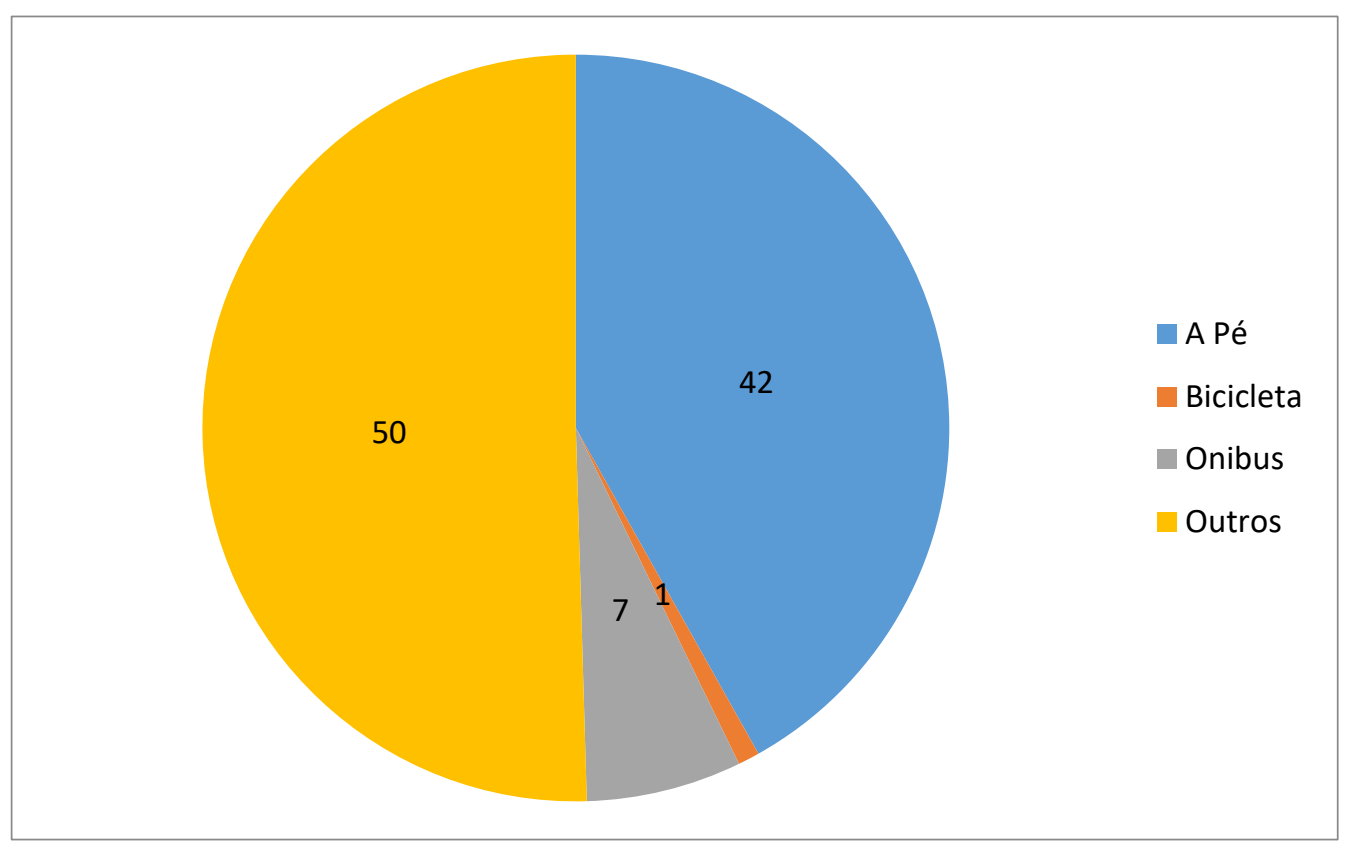

Figura 6.35 - Probabilidade de escolha dos modos - Goiânia 
Avaliando a figura 6.34 percebe-se que os resultados do modelo de regressão corroboram com a pesquisa realizada na cidade de Goiânia com certa precisão. Para o modo caminhamento, a probabilidade de escolha foi de $42 \%$ diferindo da pesquisa realizada em 10,5\%. Para o modo bicicleta, a probabilidade de escolha equivale a $1 \%$ enquanto na pesquisa realizada equivale a $3 \%$. Para o modal ônibus, a probabilidade de escolha equivale a $7 \%$ enquanto a pesquisa aponta um índice de $9 \%$. Considerando outros modos de transporte que inclui as motos, vans de transporte escolar e os carros, os resultados do modelo numérico com a pesquisa realizada coincidiram em $50 \%$.

$\mathrm{Na}$ figura 6.35 podem-se observar as probabilidades de escolha do modo por região administrativa. Observa-se que, no monitoramento por região, o comportamento do modelo de regressão retrata com boa acurácia os resultados da pesquisa. Quando alimentado o modelo numérico com os dados dos questionários, o índice de acerto do modelo foi equivalente a $75 \%$.

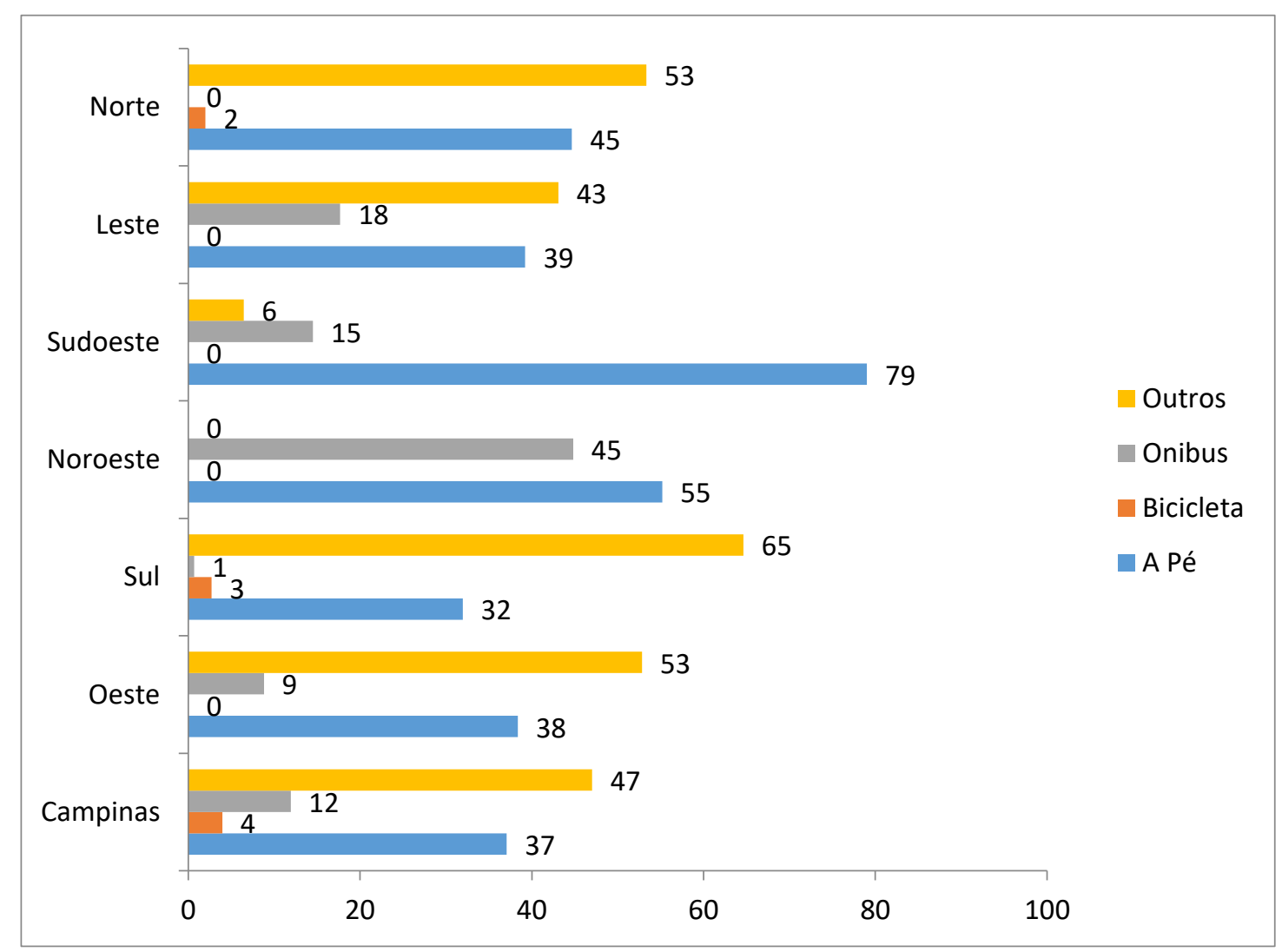

Figura 6.36 - Probabilidade de escolha dos modos - Goiânia 
Conclusões e

Sugestões 


\subsection{CONCLUSÕES E SUGESTÕES}

\subsection{CONCLUSÕES}

A presente pesquisa teve como objetivo principal a avaliação da relação entre as variáveis da forma urbana e a escolha do modo de transporte pelos pais na condução de filhos até a escola. Nesta avaliação realizou-se um estudo de caso na cidade de Goiânia com famílias de crianças matriculada no ensino fundamental na rede municipal, estadual e privada.

Elaborou-se um questionário visando explorar as diversas variáveis que serviram para compor o modelo comportamental. Nestas variáveis estão incluídas àquelas relacionadas com as características socioeconômicas, às mediadoras e de moderação além daquelas que exploram a forma urbana. Construiu-se um modelo comportamental de regressão do tipo logit multinomial que possibilitou identificar a função utilidade para o problema em questão e as probabilidades de escolha dos indivíduos.

De uma forma geral, o modelo de regressão elaborado na presente pesquisa se mostrou satisfatório estatisticamente. Considerando o modo caminhamento, os resultados demonstraram um peso maior de variáveis relacionadas à forma urbana especialmente àquelas ligadas a área do setor, o comprimento e densidade de vias, a conectividade, a largura média das calçadas e as linhas de transporte coletivo que atendem e margeiam o setor.

Algumas variáveis relacionadas à forma urbana não tiveram um forte peso dentro da função utilidade como esperado inicialmente. Destacam-se variáveis como o número total de quadras, o comprimento médio das quadras, o número e tipo de intercessões além da densidade das intercessões. Acredita-se que um refinamento melhor do modelo de regressão considerando apenas as variáveis da forma urbana possibilita mensurar a importância ou não no processo de escolha dos modais de transporte. Interessante ressaltar que são variáveis que tiveram pequeno peso, mas que são importantes para a estabilidade do modelo de regressão e no aumento do seu índice de confiança.

Com a construção do modelo estatístico de regressão logística foi possível considerar a influência dos fatores de mediação e moderadores na análise além da interação com as variáveis de forma urbana. Todos esses fatores apresentaram uma baixa 
significância o que pode ser justificado pelo questionário aplicado onde se pretendia explorar com maior precisão a influência da forma urbana.

No que tange ao modo caminhamento destacamos a maior opção dos indivíduos que conduzem alunos da rede municipal e estadual em relação à particular. Chama atenção o alto índice de escolha por outros modos de transporte, da rede particular, o que pode explicar os altos índices de congestionamentos nas imediações das escolas privadas na cidade de Goiânia.

O modelo detectou que quando o indivíduo principal que acompanha a criança até a escola é a mãe, a chance de opção pelo caminhamento como modo de transporte principal, é maior em relação à bicicleta, ônibus e outros. Quando o indivíduo é o pai da criança a probabilidade é maior de utilizar outros meios de transporte em comparação com os demais modos. Quando se questiona a influência da distância na escolha do modo, os resultados apontaram uma baixa influência das variáveis o que pode ser justificado pelo fato de que a maioria das famílias residem nas proximidades das escolas o que diminui a distância a percorrer.

Outra conclusão obtida é a influência de um modo sobre outro dentro de um setor. Nos bairros onde existem um número maior de linhas do transporte público urbano que atendem os mesmos ocorre uma redução das chances dos indivíduos em optar pelo modo caminhamento. Quando a quantidade de linhas do transporte público urbano que apenas margeiam o setor, é maior, ocorre uma inversão e as chances dos indivíduos em conduzirem as crianças a pé, aumenta. Chama a atenção de variáveis com forte significância como a largura média das calçadas que estimulam a opção pelo modo a pé em detrimento aos modais bicicleta, ônibus e outros.

A elaboração de modelos de regressão como o utilizado na presente tese pode constituir de uma importante ferramenta para auxílio aos profissionais de urbanismo quando na elaboração de projetos visando estimular a utilização de modais mais sustentáveis. A tabela de probabilidades obtida apresentou um índice de acerto de $75 \%$, o que pode ser considerado satisfatório.

Espera-se que os resultados obtidos nesta pesquisa sirvam como referencial teórico para os urbanistas e autoridades na tomada de decisões que venham a estimular a demanda de viagens não motorizadas e, consequentemente, a redução dos congestionamentos nas imediações das escolas nos grandes centros. 


\subsection{SUGESTÕES PARA TRABALHOS FUTUROS}

De forma a dar continuidade a presente linha de pesquisa são sugeridos alguns temas para serem investigados e que buscam contribuir para a compreensão do modelo comportamental e a escolha dos modos de transportes pelos usuários. Dentre muitas sugestões recomenda-se:

- No presente trabalho optou-se em avaliar a forma urbana na escolha dos indivíduos pelo modo caminhamento, comparando-se com outros modos de transporte. É interessante avaliar a influência da forma urbana na escolha do modo bicicleta e do transporte público urbano. Espera-se que o presente estudo identifique as variáveis que mais influenciam na escolha de modais mais sustentáveis;

- Os resultados da presente tese demonstraram que se faz importante realizar uma pesquisa utilizando modelos de regressão e enfatizando as variáveis socioeconômicas como faixa de renda, número de automóveis, número de crianças no domicilio, sexo e idade das crianças, etc. Ao ressaltar estas variáveis espera-se um aumento da precisão do modelo comportamental;

- Avaliar numa nova pesquisa a contribuição dos fatores mediadores como a segurança do bairro, a segurança do tráfego e as opções de transporte na escolha do modo pelo indivíduo para a condução das crianças até a escola. Os fatores moderadores como atitude dos pais e as características sócio demográficas podem ser incluídas no presente estudo e estabelecidas as devidas comparações de forma a mensurar os pesos dessas variáveis no modelo de regressão;

- É importante averiguar o comportamento de um modelo de regressão mais simples, o binomial, na validação dos resultados encontrados. Os modelos mais simplificados são úteis para estimativas mais rápidas, com precisão satisfatória e que sirvam de subsídios para a elaboração de anteprojetos na área de urbanismo.

- O complexo processo de tomada de decisão sobre o deslocamento até a escola é influenciado por outras variáveis e não investigadas nessa Tese, como tempo e custo de viagem. Para um estudo mais aprofundado do assunto propõem-se a utilização de um modelo baseado em atividades para um melhor entendimento das decisões de viagens. 


\section{REFERÊNCIAS BIBLIOGRÁFICAS}

ABBAD, G. S.; TORRES, C. V. Regressão múltipla stepwise e hierárquica em psicologia organizacional: Aplicações, problemas e soluções. Estudos de Psicologia, Natal, v. 7, (número especial), p. 19-29, 2002.

ALLAN, A. Walking as a Local Transport Modal Choise in Adelaide. World Transport Policy e Practive, volume 7, $\mathrm{n}$ `2, p. 44-51, 2001.

AMÂNCIO, M. A. Relacionamento entre a Forma Urbana e as Viagens a Pé. 2005. 88 p. Dissertação (Mestrado em Engenharia Urbana) - Departamento de Engenharia Civil, Universidade Federal de São Carlos, São Carlos, 2005.

ANTP - Associação Nacional de Transportes Públicos. Sistema de Informação da Mobilidade Urbana: Relatório Geral 2012. (interne) Disponível em: http://www.antp.org.br/ 5dotSystem/userFiles/simob/relat\%C3\%B3rio\%20geral\%19 99.pdf [Acessado em janeiro de 2013].

ANTP - Associação Nacional de Transportes Públicos. Transporte humano: cidades com qualidade de vida. Coordenadores: Ailton Brasiliense Pires, Eduardo Alcântara Vasconcelos, Ayrton Camargo e Silva. São Paulo: ANTP, 1997.

ANTP - Associação Nacional dos Transportes Públicos. XII Congresso Brasileiro de Transporte e Trânsito. Disponível em http://www.antp.org.br, acessado em 20.03.2015.

ARRUDA, F. S. Integração dos Modos não Motorizados nos Modelos de Planejamento dos Transportes, 2000. Dissertação (Mestrado em Engenharia Urbana)Departamento de Engenharia Civil. Universidade Federal de São Carlos, São Carlos, 2000.

BANNISTER, D. Sustainable urban development and transport - a Eurovision for 2020. Transport Reviews, 20: p. 113-20, 2000.

BANNISTER, D. The Sustainable Mobility Paradigm. Transport Policy, 15 (2): p. 73-80, 2008.

BARON, R. M.; KENNY, D.A. The Moderator- Mediator Vriable Distinction in Social Psychological Research: Conceptual, Strategic, and Statistical Considerations. Journal of Personality and Social Psychology, 51 (6): 1173-1182, 1986. 
BARROS, A. P. B. G. Diz-me com quem andas que direi com quem estás: inserção do aspecto relacional na análise da mobilidade urbana para pedestre. Tese de doutorado. UnB, Faculdade de Tecnologia. Departamento de Engenharia Civil e Ambiental. Brasília, 2014.

BEN-AKIVA, M. E.; LERMAN, S. R. Discrete Choice Analysis: theory and application to travel demand. p. 100-129. Acesso em 2014 <http://books.google.com.br/books>, 1985.

BOARNET, M.; ANDERSON; C.; DAY, K.; McMILLAN, T.; ALFONZO, M. 2005. Evaluation of the California Safe Routes to School legislation: urban form changes and children's active transportation to school. American Journal of Preventive Medicine, 28(2S2), 134-140, 2005.

BOARNET, M.; CRANE, R. The influence of land use on travel behavior: specification and estimation strategies. Transportation Research Part A 35, 823-845, 2001.

BRADSHAW, R.; ATKINS, S. The use of public transport for school journeys in London. Proceedings of seminar F: Public transport planning and operations, 2-6, 1996.

CARDOSO, R. A. Trajetória dos Movimentos Sociais. In: DAGNINO, E. (org.). Os anos 90: Polírica e Sociedade no Brasil. São Paulo: Brasiliense, 1994.

CERVERO, R. Built environments and mode choice: toward a normative framework. Transportation Research, Part D, no. 7, pp. 265-284, 2002.

CERVERO, R. The transit metropolis: a global inquiry, Island Press, Washington, D.C. Transportation Research no. 24: 125-138, 1998.

CERVERO, R.; SARMIENTO, O. L.; JACOBY, E.; GOMEZ, L. F.; NEIMAN, A. Influences of Built Environments on Walking and Cycling: Lessons from Bogotá. International Journal of Sustainable Transportation, Volume 3, issue 4, p. 203-226, 2009.

CERVERO, R; DUNCAN, M. Walking, bicycling, and urban landscapes - evidence from San Francisco Bay Area. American Journal of Public Health, v. 93, n. 9, p. 1478-1483, 2003.

CERVERO, R; KOCKELMAN, K. Travel Demand and the 3Ds: Density, Diversity and Design. Transportation Research, vol. 2, no. 3, pp. 199-219, 1997. 
CHAVEIRO, E. F. Goiânia, uma metrópole em travessia. 2001. Tese (Doutorado em Geografia) - Universidade Estadual de São Paulo; São Paulo.

CUNHA, J.M.P. Migração e Urbanização no Brasil: alguns desafios metodológicos para análise: São Paulo em pespectiva. Journal São Paulo Perspectiva vol.19 no.4 São Paulo Oct./Dec. 2005.

DELLINGER, A.M.; SATAUTON, C. E. Barriers to children walking and biking to SchoolUnited States,1999, Journal of the American Medical Association, 288 (2002), pp. 1343-1344.

DEUS, L. R. de. A influência da forma urbana no comportamento de viagem das pessoas: estudo de caso em Uberlândia, MG. Dissertação de Mestrado. UFScar. São Carlos. 2008.

DiGUISEPPI, C.; ROBERTS, I.; LI, L.; ALLEN, D. Determinants of Car Travel on Daily Journeys to School: Cross Sectional Survey of Primary School Children. British Medical Journal, 316, 1426-1428, 1998.

DILL, J. Measuring Network Connectivity for Bicycling and Walking. Transportation Research Record, 2004.

EICHELBERGER, M.R.; GOTSCHALL, C.S; FEELY, H. B.; HARSTAD, P.; BOWMAN, L. Parental Attitudes and Knowledge of Child Safety: a National Survey. American Journal of Diseases of Children, 144: 714-720, 1990.

EWING, R.; CERVERO, R. (2010) Travel and the built environment. Journal of the American Planning Association, vol. 76, n. 3, pp. 265-294.

FERRARI, C. Curso de Planejamento Municipal Integrado. São Paulo: Livraria Pioneira, 1979.

FERRAZ, A. C. C. P. Escritos sobre transporte, trânsito e urbanismo. 1. ed. Ribeirão Preto: São Francisco, 1998.

FERRAZ, A. C. P.; TORRES, I. G. E. Transporte Público Urbano. 2. ed. São Carlos: Rima, 2004. 
FERREIRA; M.A.G., SANCHES; S.P. Índice de qualidade das calçadas - IQC. Revista dos transportes públicos- ANTP, 2o trimestre, pp 47-60, 2011.

FHWA Federal Highway administration, Roundabouts: An informational guide, 2000.

FRANK, L.D.; PIVO, G. Imapcts of mixed use and denity on utilization of three modes of travel: single-occupant vehicle, transit and walking. Transportation Research Record 1466, 44-52, 1994.

GEHL, J. Cities for people. Washington D.C.: Island Press, 2010.

GEHL, J.; SYARRE, B. How to Study Public Life. Washington D.C.: Island Press, 2013.

GODIM, M.F. (2001). O Transporte Não Motorizado na Legislação Urbana no Brasil. 201f. Dissertação de Mestrado em Transportes. Universidade Federal do Rio de Janeiro - COPPE/UFRJ. Rio de Janeiro, 2001.

GONÇALVES, A. R. Goiânia: uma modernidade possível. Brasília: Ministério da Integração Nacional: Universidade Federal de Goiás, 2003.

HANDY, S.L. Methodologies for exploring the link between urban form and travel behavior travel in five neighborhoods in the San Francisco Bay Area. Transportation Research D, 1(2): 151-165, 1996c.

HANDY, S.L. Understanding the link between urban form and nonwork travel behavior. journal of Planning Education and Research, 15: 183-198, 1996a.

HANDY, S.L. Urban form and pedestrian choices: study of Austin neighborhoods. Transportation Research Record, 1552: 135-144, 1996b.

HANDY, S.L.; CLIFTON, K.J. Local shopping as a strategy for reducing automobile travel. Transportation, 28: 317-346, 2002.

HIGHWAY CAPACITY MANUAL. Transportation Research Board. Nacional Research Council, Washington, 2000.

HILLMAN, M. A. Personal Mobility and Transport Policy PEP Broadsheet 542 London, Policy Studies Institute, 1973. 
HILLMAN, M.; ADAMS, J.; WHITELEGG, J.: One False Move: A Study of Children's Independent Mobility. Policy Studies Institute, London, 1990.

HOFFERTH, S. L.; BRAYFIELD, A.; DEICH, S.; HOLOCOMB, P. National child care survey, 1990. Washington, DC: Urban Institute Press; 1991.

HUEBNER, A. J.; MANCINI, J. A. Shaping structured out-of-school time use among youth: The effects of self, family, and friend systems. Journal of Youth and Adolescence, 32, 453-463, 2003.

IBGE - Instituto Brasileiro de Geografia e Estatística, CENSO DEMOGRÁFICO. Goiânia, 2010.

JACOBS, J. Morte e vida de grandes cidades. São Paulo: Ed. Martins Fontes, 2000.

KITAMURA, R.; MOKHTARIAN, P.L.; LAIDET, L. A micro-analysis of land use and behavior. Transportation Research D, 1(2): 151-165, 1997.

KRIZEK, K. J. Operationalizing neighborhood accessibility for land use - travel behavior research and regional modeling. Journal of Planning Education and Research 22. pp. 270-287, 2003.

KRIZEK, K.J.; BIMBAUM, A.S.; LEVINSON, D.M. A Schematic for Focusing on Youth in Investigations of Community Design and Physical Activity. American Journal of Health Promotion, 19, 33-38, 2004.

LESLIE, A. M.; GERMAN, T. P.; POLIZZI, P. Beliefdesire reasoning as a process of selection. Cognitive Psychology, 50, 45-85, 2005.

LIU, T., MA, J.; GUAN, W.; SONG, Y.; NIU, H. Bus Arrival Time Prediction Based on the k-Nearest Neighbor Method. In Computational Sciences and Optimization (CSO), 2012 Fifth International Joint Conference on. pp. 480-483, 2012.

MAHONEY, J. L.; STATTIN, H. Leisure activities and adolescent antisocial behavior: The role of structure and social context. Journal of Adolescence, 23, 113-127, 2000.

MANSO, C. F. A. A Questão Urbana Derivada das Transformações Econômico-Sociais em Armando Augusto de Godoy: A Cidade Desejada sobre a Cidade que se tem. XVI ENANPUR, v-3 p. 108-120, 2013. 
MARINHO, C. B. Região Sul de Goiânia: Um Lugar Valorizado na Metrópole. Programa de Pesquisa e Pós-Graduação em Geografia/ UFG- Goiânia. GEOUSP- Espaço e Tempo, n 19, pp. 113-129, São Paulo, 2006.

MATOS, A. P., PEREIRA, B. O., \& ALMEIDA, M. J. (2014). Transporte para a escola na atividade física do adolescente. In B. O. Pereira, A. N. Silva, A. C. Cunha, \& J. V. Nascimento (Eds.), Atividade Física, Saúde e Lazer: olhar e pensar o corpo (pp. 182192). Florianópolis: Tribo da llha.

McDONALD, N. Children's Travel: Patterns and Influences PhD dissertation, Department of City and Regional Planning, University of California, Berkeley, CA, 2005.

MCDONALD, D.R.; STAMMER, R.E. Contribution to the Development of Guidelines for Toll Plaza Design. Journal of Transportation Engineering, v. 127, n. 3, p. 215-222, 2001.

McDONALD, N. Active transportation to school: trends among U.S. schoolchildren, 1969-2001. Am. J. Prev. Med. 32(6), 509-516, 2011.

McDONALD, N. Children's mode choice for the school trip: the role of distance and school locations in walking to school. Transportation, 35, 23-35, 2008.

MCKIBBIN, M. The Influence of the Built Environmet on Mode Choice. Evidence from the Journey to Work Sydney, Australasian Transport Research Forum 2011. Adelaide, Australia, 28-30 setember, 2011.

McMILLAN, T. E. Walking and urban form: Modeling and testing parental decisions about children's travel. Unpublished doctoral dissertation. University of California, Irvine, 2003.

MEDEIROS, V. A. S. UrbisBrasiliae ou sobre cidades do Brasil: Inserindo Assentamentos Urbanos do País em Investigações Configuracionais Comparativas. Tese (Doutorado em Arquitetura e Urbanismo) - Programa de Pesquisa e Pósgraduação da Faculdade de Arquitetura e Urbanismo, Universidade de Brasília, Brasília, 2006.

MORAES, S. de. O empreendedor imobiliário e o Estado - a expansão sul de Goiânia1975 a 1985. Dissertação de Mestrado. Faculdade de Arquitetura da Universidade de Brasília, 1991. 
MOUDON, A. V.; Lee, C.; CHEADLE, A. D.; GARVIN, C.; JOHNSON, D., SCHMID, T. L., WETHERS, R. D., e LIN, L. Operational definitions of walkable neighborhood: theoretical and empirical insights. Journal of Physical Activity and Health, vol. 3, n. 1, pp. 99-117, 2006.

MOYSÉS, Aristides. Goiânia: Metrópole não planejada. Goiânia: Editora da UCG, 2004.

NOVAES, A. G. Sistemas de Transportes: Análise da Demanda. Edgard Blücher Ltda. Vol. 1. São Paulo - SP, 151 p, 1986.

OGILVIE, D.; BULL, F.; COOPER, A.; RUTTER, H.; ADAMS, E.; BRAND. C. Evaluating the travel, physical activity and carbon impacts of a "natural experiment" in the provision of new walking and cycling infrastructure: methods for the core module of the iConnect study. BMJ. 2012.

OLIVA, S. De la Fuente i La Influencia de la Forma Urbana en la Movilidad: un studio para el caso de Cataluña. Documents de Recercadel Programa de Doctorado em Economía Aplicada Universitat Autònoma de Barcelona, 2007.

ORTÚZAR, J. D.; WILLUMSEN, L. G. Modelling Transport. Inglaterra: John Wiley e Sons Ltda., 375 p., 1994.

PASANEN, E. The Video Recording of Traffic Accidents. Report $\mathrm{n}^{\circ} 1993: 4$, Helsinki Finland City Planning Departament, 11pp, March,1993.

PIKE J. (2003). Lipid rafts: bringing order to chaos, Journal of Lipid Research, 44: 655 667.

PITOMBO, C. S.; KAWAMOTO, E. Análise de Relações entre Variáveis Socioeconômicas, Geográficas e do Sistema de Transportes e Padrões de Encadeamento de Viagens Urbanas. Panorama Nacional de Pesquisa em Transportes, XVIIIAnpet, v.3 - p. 91-94, 2004.

PLANO DIRETOR DE GOIÂNIA. Lei Complementar nํ 171/2007. Goiânia, 2007.

PONT,K.,; ZIVIANI, J.; WADLEY, D.; BENNETT, S.; ABBOTT, R. Environmental Correlates of Children's Active Transportation: as Systematic Literaturer Review. Health Place 15(3),849-862, 2009.

RAIA Jr., A. A. Acessibilidade e Mobilidade na Estimativa de um Índice de Potencial de Viagens utilizando Redes Neurais Artificiais e Sistemas de Informação. Tese, 
Doutorado em Engenharia Civil - Transportes pela Universidade de São Paulo, Escola de Engenharia de São Carlos. São Carlos, 2000.

RIBEIRO, M. E. J. Goiânia: os planos, a cidade e o sistema de áreas verdes. Goiânia: Editora da UCG, 2004.

RODRÍGUEZ, D. A.; Joo, J. The relationship between non-motorized mode choice and the local physical environment. Transportation Research Part D: Transport and Environment, 9(2), 151-173, 2004.

ROSENBLOOM, S. The Impacto f Growing Children on their Parent's Travel Behavior: a Comparative Analysis. Tranportation Research Record, 1135:17-25, 1987.

Secretaria Municipal de Desenvolvimento Urbano Sustentável (SEMDUS)Departamento de Pesquisa, Estatística e Estudos Socioeconômicos da Diretoria de Informações Urbanas e Geoprocessamento (2013). Disponível em: http://www.goiania.go.gov.br/shtml/seplam/anuario2013/arquivos\%20anuario/3\%20 DEMOGRAFIA/3.1\%20Popula\%C3\%A7\%C3\%A3o/3.1.1\%20Evolu\%C3\%A7\%C3\% A30\%20da\%20popula\%C3\%A7\%C3\%A30\%20-\%20Goi\%C3\%A2nia\%20\%202000-2013.pdf. Acesso 01 novembro de 2016.

SHANN, M. H. Professional Commitment and Satisfaction among Teachers in Urban Middle schools. The Journal of Educational Research, 92 No. 2, 67- 73, 2001.

SILVA, K. S.; LOPES, A. S. Excesso de Peso, Pressão Arterial e Atividade Física no Descolamento à Escola. Arquivos Brasileiros de Cardiologia, v.91, p. 93-101, 2008.

SILVA, K. S; LOPES, A. S; SILVA, E. M. Atividade Física no Deslocamento à escola e no Tempo Livre em Crianças e Adolescentes da Cidade João Pessoa, Paraíba, Brasil. Revista Brasileira Cidades e Movimento, 15 (3): 61-70, 2007.

SILVA, S. G.; DUCA, G.F.D.; SILVA, K. S.; OLIVEIRA, E. S. A; NAHAS, M. V. Deslocamento para o trabalho e fatores associados em industriários do sul do Brasil. Revista de Saúde Pública, São Paulo, v. 46, n. 1, p. 180-184, 2012.

SILVA. R. U. DA; LIMA, N. N DE; QUEIROZ, D. DA R.; POMPÍLIO, R. G. DE S.; FREITAS, C. M. S. M. Características Sociodemográficas e Deslocamento Ativo em Adolescentes Escolares. Revista Saúde e Pesquisa, v. 7, n. 3, p. 383-388, set./dez. 2014.

SIMOB/ANTP (2011) Sistema de Informações de Mobilidade Urbana/ Associação Nacional de Transportes Públicos (2011). Disponível em: 
$<\mathrm{http}$ //www.antp.org.br/website/produtos/sistemas-de-informacoes-damobilidade/show.asp?ppgCode=-D90B394F-706E-40A8-A286-EBEA56C05A0B > .

Acesso em: 13 nov. 2016.

SOUZA, C. O.; SILVA, R. C. R.; ASSIS, A. M. O.; FIACCONE, R. L.; PINTO, E. J.; MORAES, L. T. L. P. Associação entre Inatividade Física e Excesso de Peso em Adolescentes de Salvador, Bahia-Brasil. Revista Brasileira de Epidemiologia, v. 13, p. 468-475, 2010.

STAUNTON, C. E.; HUSBMITH, D.; KALLINS, W. Promoting Safe Walking and Biking to School: The Marin County Success Story. American Journal of Public Health, Callifornia, Vol 93, No. 9, September 2003.

TAKANO, M. S. M. Análise da influência da forma urbana no comportamento de viagens encadeadas com base em padrões de atividades. Dissertação (Mestrado em Transportes) - Departamento de Engenharia Civil e Ambiental, Faculdade de Tecnologia da Universidade de Brasília, Brasília, 2010.

TUDOR-LOCKE, C.E.; MYERS, A.M. Methodological considerations for researchers and practitioners using pedometers to measure physical (ambulatory) activity. Research Quarterly for Exercise and Sport72, 1-12, 2001.

VASCONCELLOS, C. S. Planejamento Projeto de Ensino-Aprendizagem e Projeto Político-Pedagógico Ladermos Libertad-1. 7ํㅡd. São Paulo, 2000.

VASCONCELLOS, E. A. O transporte urbano no Brasil. ANTP- Associação Nacional dos Transportes Públicos, "Sistema de Informação da Mobilidade", 2011. Disponível em: $<$ www.antp.org.br $>$.

VASCONCELLOS, E. A. Transporte urbano, espaço e equidade: análise das políticas públicas. São Paulo: Annablume, 2001.

VASCONCELLOS, E. A. Políticas de Transporte no Brasil. São Paulo. Ed. Manole, 2014

VAZ, M. D. A. C. Transformação do centro de Goiânia: renovação ou reestruturação? Dissertação (Mestrado em Geografia) - Instituto de Estudos Sócio-Ambientais da Universidade Federal de Goiás, Goiânia, 2002.

VILLOTA, J. Urbanismo, planificación y diseño. La cidad y sus disciplinas. Entorno urbano 1999 - 2001. Dissertação (Maestría en Diseño Urbano), Universidad Metropolitana, Caracas, 2001. 
VLIET, W. V. Children's travel behavior. Ekistics 298, 61-65, 1983.

WHO - World Health Statistics. Cause-specific mortality rate (per 100000 population). Disponível em: www.who.int, 2010.

YARLAGADDA, A. K.; SRINIVASAN, S. Modeling Children's School Travel Mode and Parental Escort Decisions. Transportation, Vol. 35, No. 2, pp. 201-218, 2008. 
Anexo

A 


\section{A.1 Dados Estatísticos}

\begin{tabular}{|l|r|r|r|r|}
\hline Região & Rede & & & \\
\hline & Estadual & Municipal & Particular & Total \\
\hline $\begin{array}{l}\text { Campinas } \\
\text { centro }\end{array}$ & 7161 & 13402 & 15245 & 35808 \\
\hline Leste & 3925 & 7990 & 5508 & 17423 \\
\hline Noroeste & 4753 & 4371 & 5239 & 14363 \\
\hline Norte & 1331 & 10384 & 5321 & 17036 \\
\hline Oeste & 2615 & 11336 & 5120 & 19071 \\
\hline Sudoeste & 2046 & 13710 & 9733 & 25489 \\
\hline Sul & 4132 & 6609 & 19165 & 29906 \\
\hline Total & 25963 & 67802 & 65331 & 159096 \\
\hline
\end{tabular}




\begin{tabular}{|c|c|c|c|c|c|c|c|c|c|c|c|c|c|c|c|c|c|c|c|c|c|c|c|c|c|}
\hline & \begin{tabular}{|l|}
$\frac{\mathrm{m}}{\mathrm{z}}$ \\
$\frac{\mathrm{z}}{\mathrm{m}}$ \\
$\mathrm{c}$ \\
\end{tabular} & & $\mathbb{\Xi}$ & 岕 & & & $\mathscr{\oplus}_{\oplus}^{\mathscr{m}}$ & & & 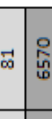 & & & :ٌ & & & $\stackrel{n}{n}$ & & 嚾 & & & & 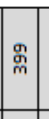 & & & 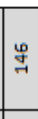 \\
\hline$\overline{\bar{\omega}}$ & 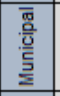 & 总 & ఊ్ & 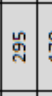 & & 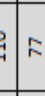 & in & $\neq$ & 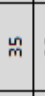 & 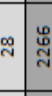 & & & 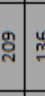 & & & 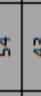 & 㕶 & 总 & & & & 离 & & & जि \\
\hline & 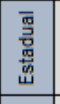 & $\underset{\pi}{\mathbb{7}}$ & 惡 & 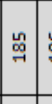 & & g & 离 & $\therefore$ & $\approx$ & 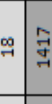 & F & & $\vec{m}$ & & $\neq$ & $\mathrm{m}=$ & $\approx$ & & & 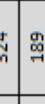 & & 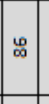 & & 学 & 이 \\
\hline & 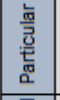 & 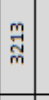 & 童 & 品 & & $\tilde{m}$ & of & in & of & ga & 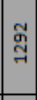 & & 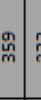 & & $\vec{\exists}$ & 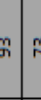 & : & 荌 & 商 & 至 & & 离 & & $\stackrel{్}{~}$ & $\infty$ \\
\hline 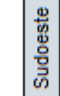 & 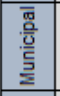 & 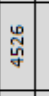 & 总 & $\approx$ & & 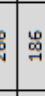 & m & | & œ & : & & $\stackrel{\substack{\infty \\
\infty}}{\infty}$ & 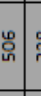 & & : & 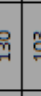 & $\Phi$ & 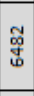 & & 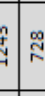 & & 志 & & $\vec{I}$ & $\approx$ \\
\hline & 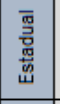 & $\stackrel{Ð}{\odot}$ & $\ddot{\nexists}$ & 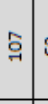 & & $\stackrel{\infty}{*}$ & $\vec{\lambda}$ & 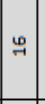 & $m$ & $\Rightarrow \equiv$ & & & $\stackrel{2}{\circ:}$ & & $\approx$ & $=$ & $m$ & 总 & & $\stackrel{8}{8}$ & & i & & $m$ & I \\
\hline & 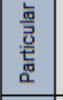 & 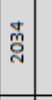 & $\stackrel{\mathbb{N}}{\sim}$ & 品? & & a & $\infty$ & $m$ & q & 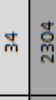 & & กิ & 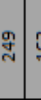 & & $\infty$ & : & 7 & 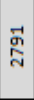 & & 售 & & 㟔 & $\frac{\pi}{9} \mid$ & n & $\overrightarrow{0}$ \\
\hline 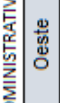 & 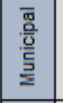 & 离 & 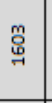 & $\stackrel{m}{\stackrel{m}{*}}$ & & 苚 & $\overrightarrow{\vec{n}}$ & $\stackrel{0}{\exists}$ & ร & $\stackrel{\vec{D}}{\circ}$ & & 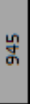 & ๓ี & & 离 & $g=$ & ส & 总 & 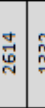 & 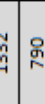 & & 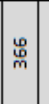 & & 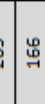 & 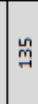 \\
\hline & 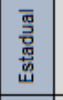 & 总 & 品 & 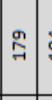 & $\overbrace{-1}^{t}$ & 8 & 出 & $\therefore$ & $\approx$ & $\stackrel{F}{A}$ & F & $\stackrel{\infty}{\sim}$ & శ్ : & & q & $m=$ & $\approx$ & $\exists$ & 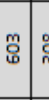 & 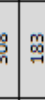 & & 出 & & & $\vec{m}$ \\
\hline & 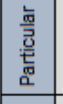 & 䋨 & ฐ్ & 离 & 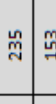 & 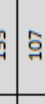 & g & $\vec{\omega}$ & q & 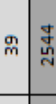 & 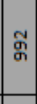 & รู & 吅 & & 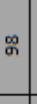 & 5 & $g$ & 总 & & $\frac{7}{6}=7$ & & 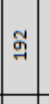 & & & $F$ \\
\hline 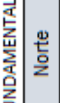 & 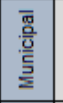 & 京 & 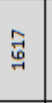 & 产 & 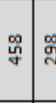 & : & 䓌 & 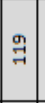 & 号: & 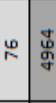 & & 喿 & 总 & & $\vec{\Xi}$ & $f=$ & แ & 总 & & fol & & $\mid$\begin{tabular}{|c|c|} 
\\
$m$ \\
$m$
\end{tabular} & & & 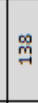 \\
\hline & 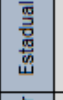 & 岕 & 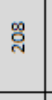 & : & 学 & $m$ & 요 & 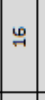 & $m$ & : & $\stackrel{g}{\mathrm{~g}}$ & & $m:$ & & 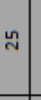 & 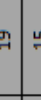 & $m$ & 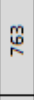 & 瞹 & 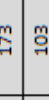 & & g & & $\pi$ & $\stackrel{9}{\sim}$ \\
\hline & 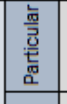 & 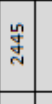 & 高 & $\stackrel{+}{+}$ & $\underset{\sim}{\widetilde{N}}$ & $\approx \approx$ & a & $\approx$ & $\stackrel{\leftrightarrow}{\sim}$ & y & Э & 恕 & 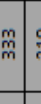 & & 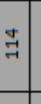 & $\infty$ & in & 零 & $\vec{g}$ & 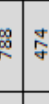 & & $\approx$ & 㟒: & I & $\aleph_{\infty}$ \\
\hline 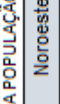 & 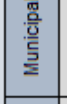 & $\mid \begin{array}{l}0 \\
\vdots \\
\vdots\end{array}$ & 照 & 鄢 & สิ & 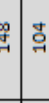 & $\approx$ & g & $f:$ & 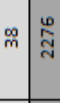 & 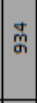 & $\vec{q}$ & $\begin{array}{c}\infty \\
\text { : }\end{array}$ & & 怘 & m: & F & 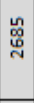 & & 嵬 & & 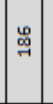 & & 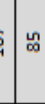 & \% \\
\hline & 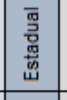 & \begin{tabular}{l}
$\infty$ \\
\multirow{2}{*}{} \\
\end{tabular} & 总 & ন & & $\underline{m}$ & $\Phi$ & 怘 & $\vec{n}$ & 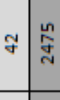 & | & ี & 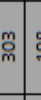 & & ১) & \begin{tabular}{l|l}
$\infty$ & 8
\end{tabular} & กิ & $\stackrel{g}{\sigma}$ & $\begin{array}{l}\substack{m \\
m} \\
\end{array}$ & 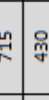 & & ฐ̃ & & & $\stackrel{n}{n}$ \\
\hline & 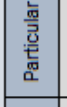 & 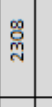 & 疋 & 章 & 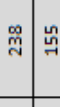 & $\stackrel{g}{g}$ & ঃ & ๘ & go & จ & 帝 & 离 & $\tilde{d}]$ & & g. & $\circ=$ & g & $\frac{\varpi}{m}$ & 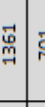 & & & $\underset{g}{ \pm}$ & & & $\approx$ \\
\hline & 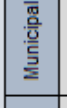 & 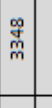 & ন্] & 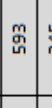 & 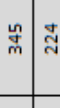 & 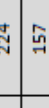 & $\stackrel{\square}{7}$ & ळ & $\therefore$ & og & 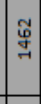 & 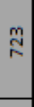 & $\stackrel{9}{\square}$ & & \pm & $\exists:$ & $\vec{F}$ & 舜 & 产 & : & & $\overrightarrow{\vec{d}}$ & & & $\stackrel{+}{\stackrel{f}{\prime}}$ \\
\hline & $\mid$ & 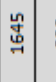 & 8 & ฐี & 의 & 其 & in & $f$ & 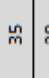 & 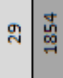 & & 品 & 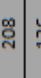 & & 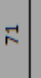 & $n$ & $\stackrel{m}{m}$ & & 옹 & $\begin{array}{l}8 \\
\end{array}$ & & 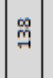 & : & & $\vec{n}$ \\
\hline & 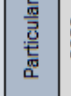 & & 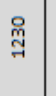 & 点 & 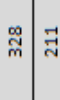 & 종 & I & $\Phi$ & $:$ & 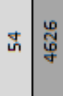 & $\mid \begin{array}{l}\text { 总 } \\
\text { | }\end{array}$ & $\stackrel{\text { to }}{\circ}$ & : & & 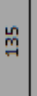 & t: & 6 & 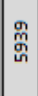 & 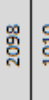 & 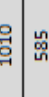 & & $\mid$\begin{tabular}{l}
$:$ \\
\hdashline
\end{tabular} & & & ô \\
\hline & $\begin{array}{l}\frac{0}{0} \\
\frac{0}{\underline{\underline{z}}} \\
\frac{1}{2}\end{array}$ & & 总 & 兽 & & : & 号 & \pm & i⿱ & $8 \mid \begin{array}{l}8 \\
\sigma\end{array}$ & 茎 & (⺻) & $\left.\begin{array}{l}: \\
\hdashline\end{array}\right]$ & & & of & ต & & 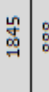 & & & 志 & & & 怘 \\
\hline & $\begin{array}{l}\frac{\mathrm{m}}{\bar{z}} \\
\frac{\mathrm{w}}{\mathrm{w}} \\
\mathrm{w}\end{array}$ & $\mid$ & i̊ & $\stackrel{8}{\mathscr{C}}$ & 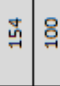 & 8 & $\vec{n}$ & \% & $\vec{m}$ & 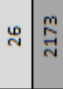 & 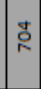 & 总 & 8:? & & $t$ & $g:$ & m & & 怘 & 岁 & & $\stackrel{\Im}{\exists}$ & mi & & $\mathscr{q}$ \\
\hline & & & 承 & 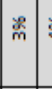 & & : & \% & 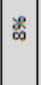 & 类 & 旁: & : & & & & & $\underbrace{\infty}_{\infty}$ & & & $:$ & & & : & o: & & 韧 \\
\hline & & & & & & $\begin{array}{lll} \\
\end{array}$ & & & & & & & & & & & & & & & & & & & \\
\hline
\end{tabular}




\section{A.3 Formulário de Pesquisa}

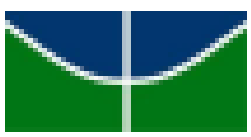

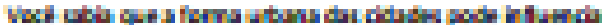

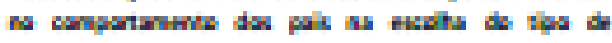

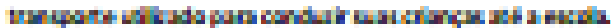

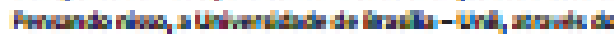

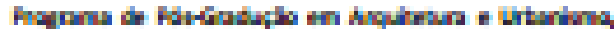

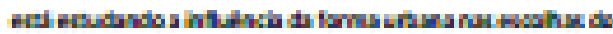

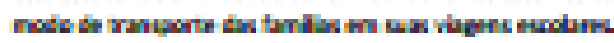

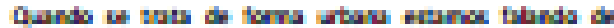

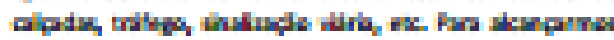

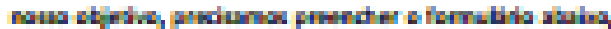

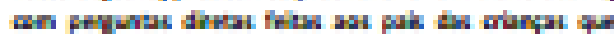

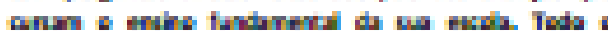

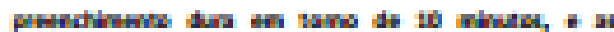

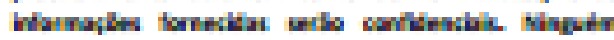

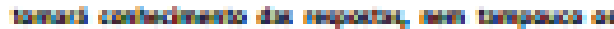

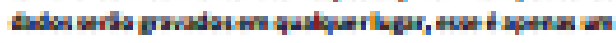

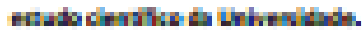

itrits

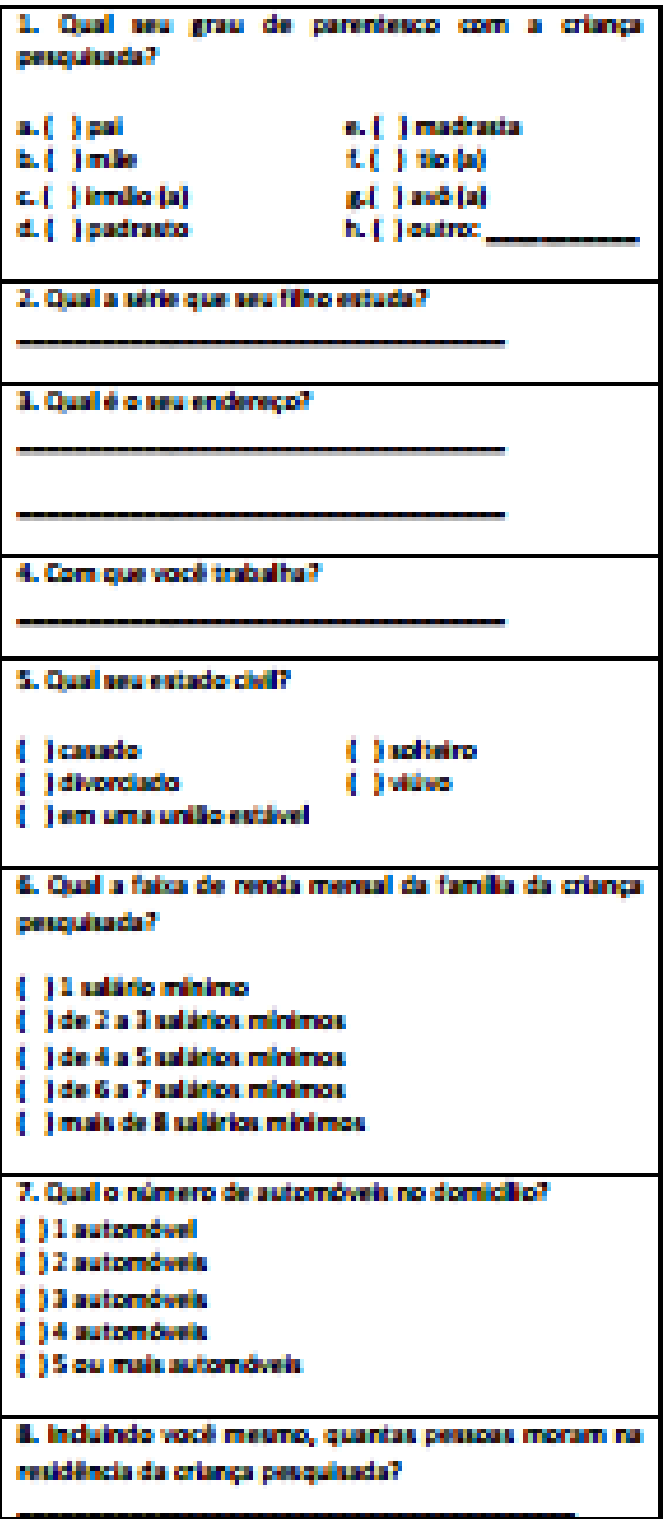

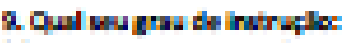

I frimi:= arw incenpluts

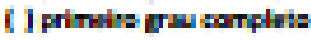

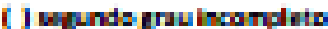

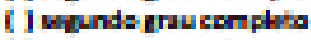

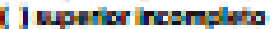

I I wprtion amplit:

i I th-roturts

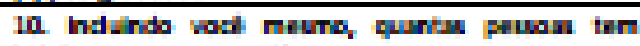

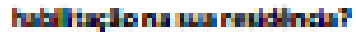

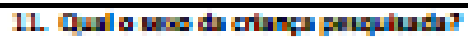

i Mnoura

1 Thenhe

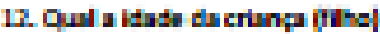

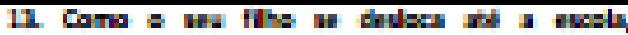
matrulnmin?

al Ina ruma difumb

b| 10 al

al jodru

di I thikan mushr

it Itankorin pitic:

다 10.tralquit

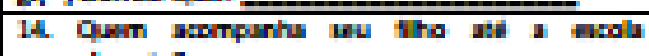
notrulnmin?
H.

비 Intr

bI I pui

ci Junsutro atitho

diturili

d| | un adiro indo

qu rusidularly

aㅣ I withth

t.I JHrith, poh

imi His vil acd

rerithe wh

a.| Inlat

bu I pal

c.l D-nsutrondato dafanilu

di 1 an curro atulo q-i rlat it thrla

c.) Inthh=

I. I I hiputir, pele min nes the wat inols with

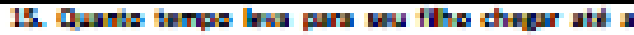
atur?

1. I marow th 5 min.

B. Intri fistin.

c. | Jatre 11 in $20 \mathrm{ml}$

di Jertr 11 in $13 \mathrm{mh}$.

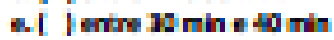

A. I ninter minstimh

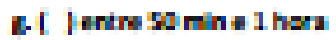

h. Imuh dis thors

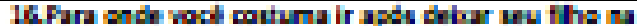
madn

i) 10stribs

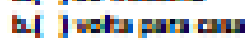

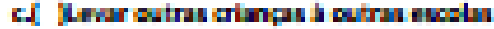

d) I arodimilu

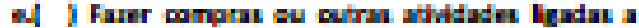
turla

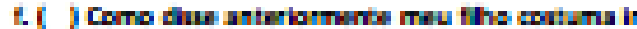
neri-the trimb

t.) 10-irestoup 


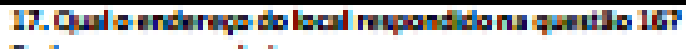
Fedh ar apanubidio

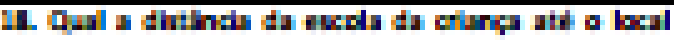

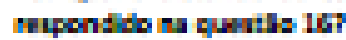

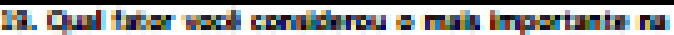
mucthuda furstuds wa the b|

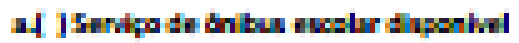

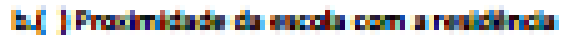

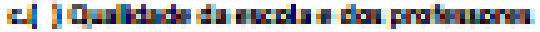

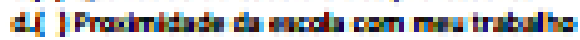

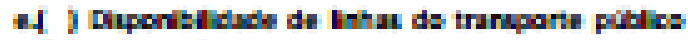
poing inolu

AI | Cutrol Ima

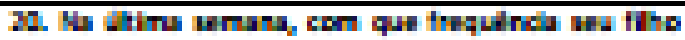

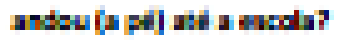

1.) | hanhunda

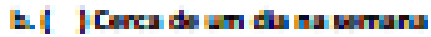

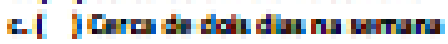

1) |Cmade triludanu wiru

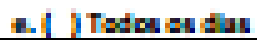

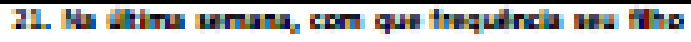

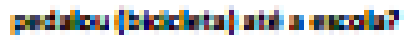

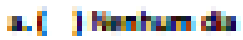

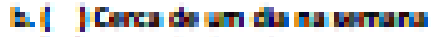

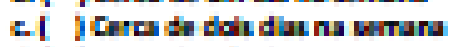

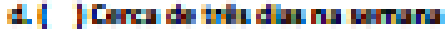

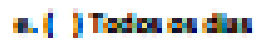

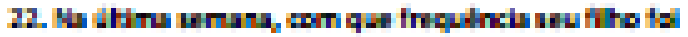
de Dituril anady?

1. I Hehur dy

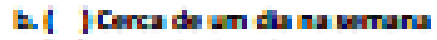

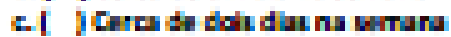

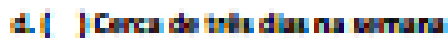

+. ITodranda

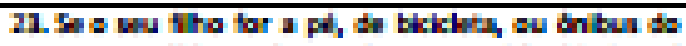

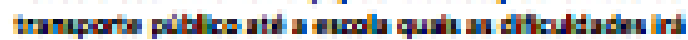

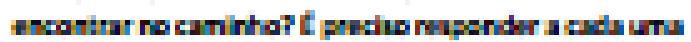

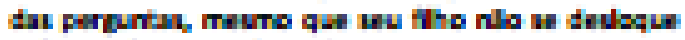

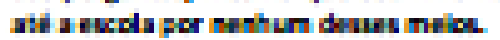

Apt

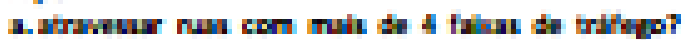
| |um | |nils

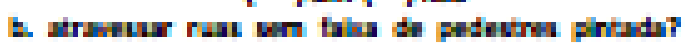
| |um | |nlts

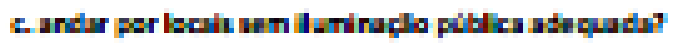

1) Inin | ing

Lindur par bah won binwabu?

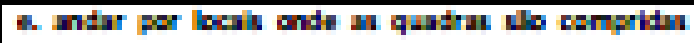
dimuh?

$$
\text { I Iut I Ina }
$$

a nu cus peusum torie ind ruplap

$$
\text { i Ium I I ra }
$$

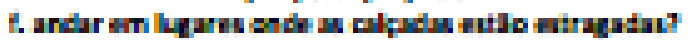
I I I I I ra

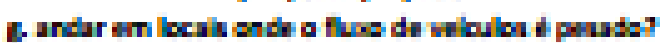

$$
\text { 1) Iut I Inla }
$$

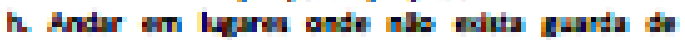
trinitor

| |dn | |nla

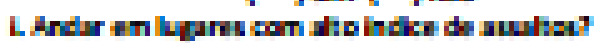

1 Jum I I na

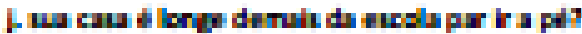

I Jumi I ria

Dekht

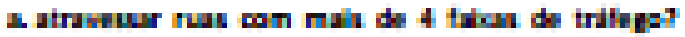

$$
\text { I Iut I I Ia }
$$

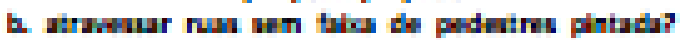
I Iut I no

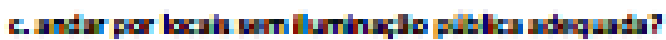
| |dr| |na

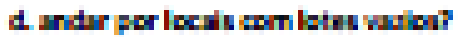

a rum com rumbal

I IHTI I ra

I I I I I I

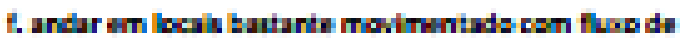
whubu

| |dn| |rib

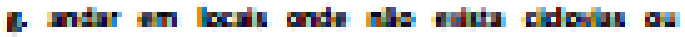
cloblunt

| |dr| | ras

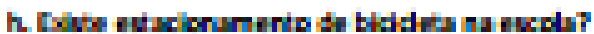

I Iut I I na

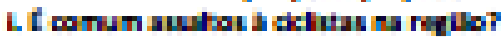

I Iut I Ia

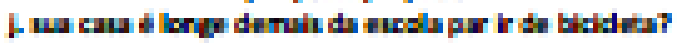

| |um| |nda

Antur

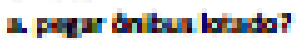

I Ium I I na

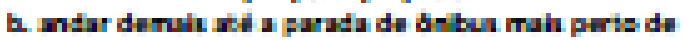
curt

I Iut I I ria

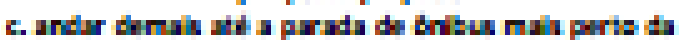
thedrif

| |dm| | rua

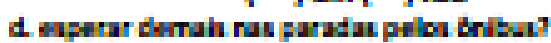

| I LTI | ra

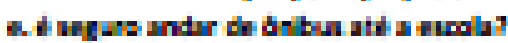

I Iur I I na

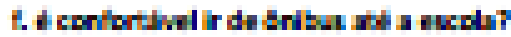

I Iut I I na

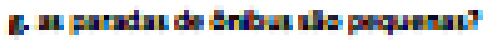

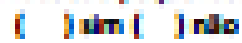

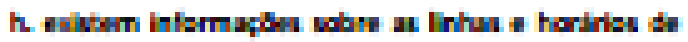

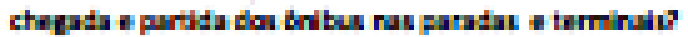

| |dm| | rib

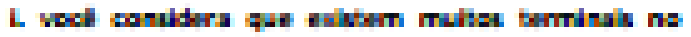

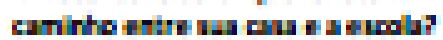

I Iut I I ra 


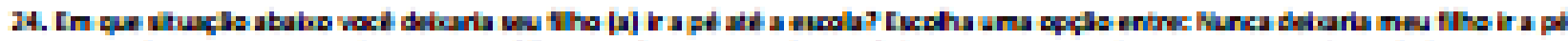

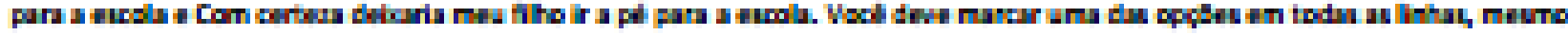

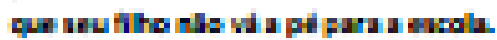

\begin{tabular}{|c|c|c|c|c|c|}
\hline & Huser & $\begin{array}{l}\text { Ata } \\
\text { gur rila }\end{array}$ & Tultur & $\begin{array}{c}\text { Acthe } \\
\text { gut uin }\end{array}$ & $\begin{array}{c}\text { Con } \\
\text { cartusu }\end{array}$ \\
\hline \multicolumn{6}{|l|}{ 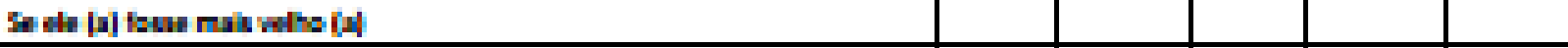 } \\
\hline \multicolumn{6}{|l|}{ Sadinafou mathr } \\
\hline \multicolumn{6}{|l|}{ Sabuho leur nuhuru } \\
\hline \multicolumn{6}{|l|}{ 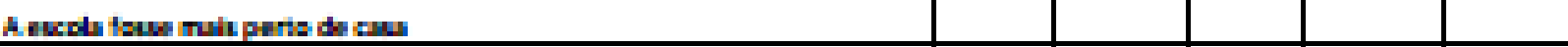 } \\
\hline \multicolumn{6}{|l|}{ 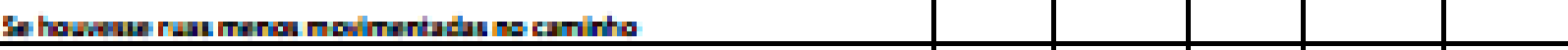 } \\
\hline \multicolumn{6}{|l|}{ 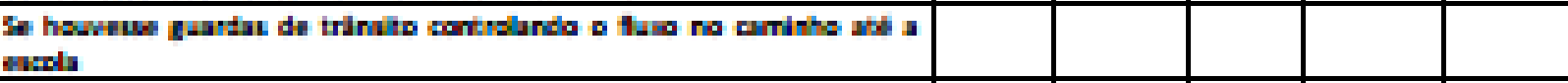 } \\
\hline \multicolumn{6}{|l|}{ 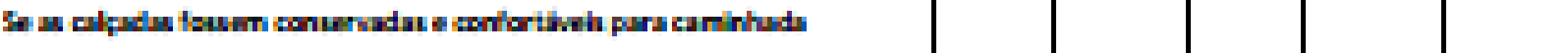 } \\
\hline \multicolumn{6}{|l|}{ 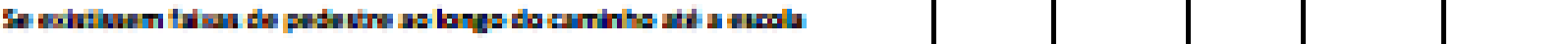 } \\
\hline 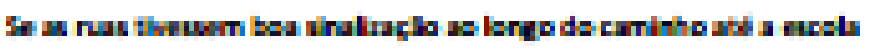 & & & & & \\
\hline
\end{tabular}

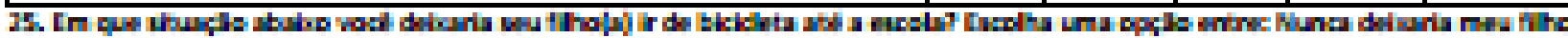

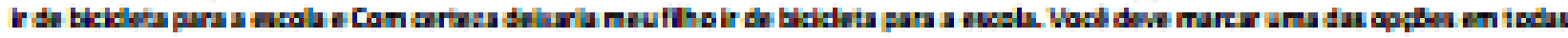

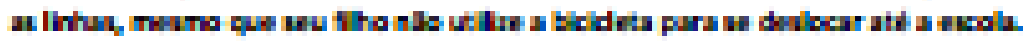

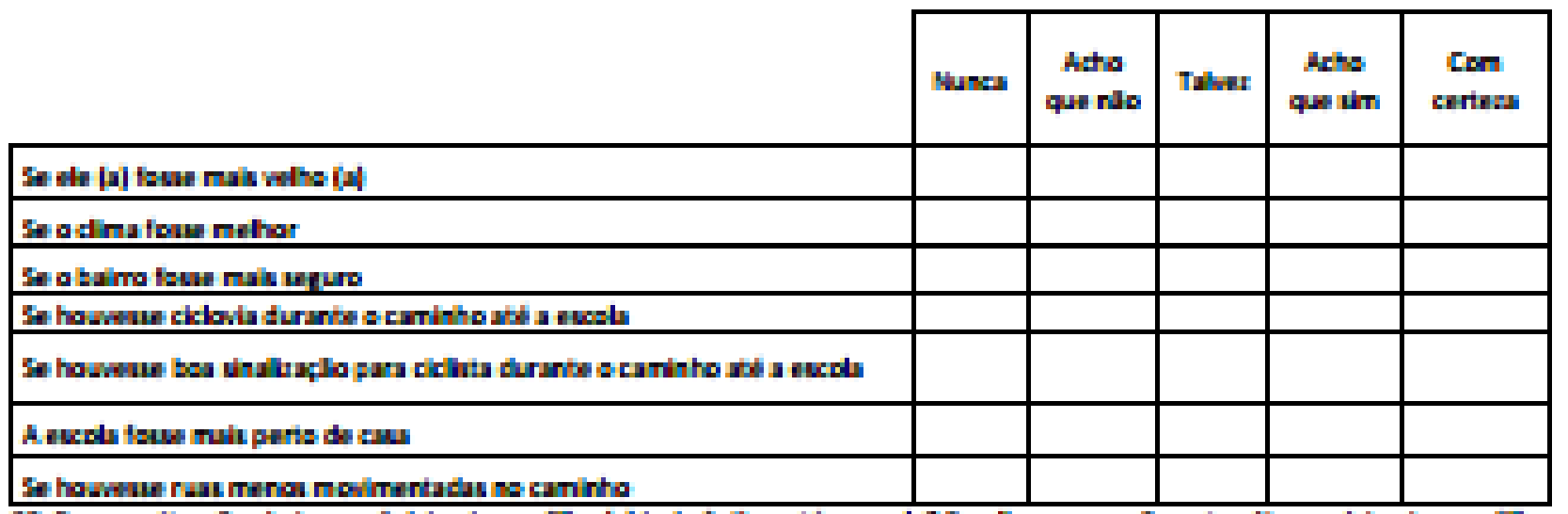

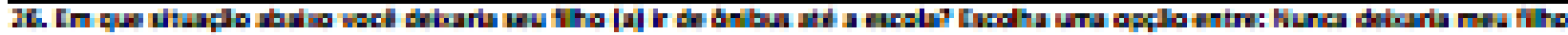

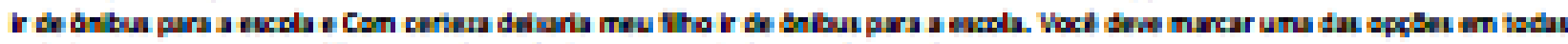

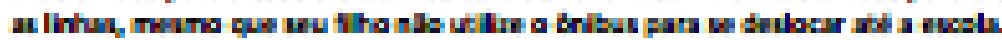

\begin{tabular}{|c|c|c|c|c|c|}
\hline & H_-c口: & $\begin{array}{c}\text { Acts } \\
\text { cpul } \\
\text { rilo }\end{array}$ & Tuln: & $\begin{array}{l}\text { Acts } \\
\text { quin } \\
\text { uim }\end{array}$ & $\begin{array}{c}\text { Com } \\
\text { certus. }\end{array}$ \\
\hline \multicolumn{6}{|l|}{ 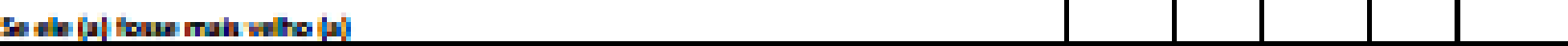 } \\
\hline \multicolumn{6}{|l|}{ 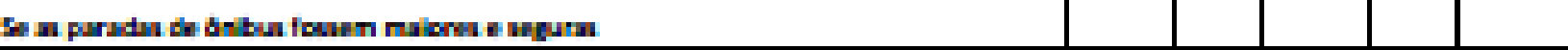 } \\
\hline \multicolumn{6}{|l|}{ 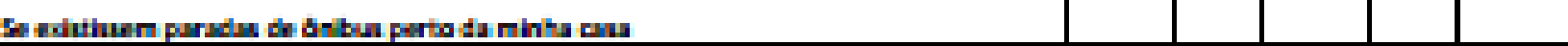 } \\
\hline \multicolumn{6}{|l|}{ 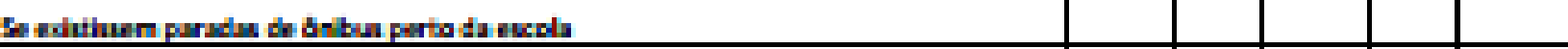 } \\
\hline \multicolumn{6}{|l|}{ 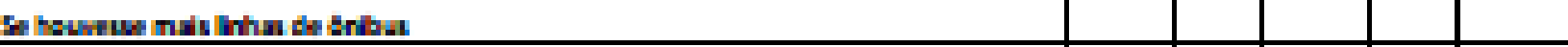 } \\
\hline \multicolumn{6}{|l|}{ Endar du S-bun tow mah rifts: } \\
\hline \multicolumn{6}{|l|}{ Esa-bulouw contur } \\
\hline \multicolumn{6}{|l|}{ 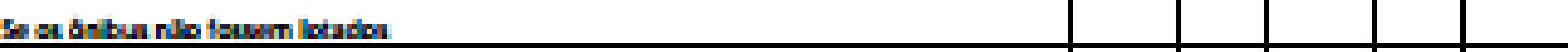 } \\
\hline \multicolumn{6}{|l|}{ 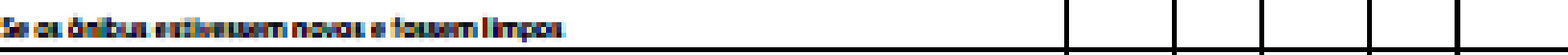 } \\
\hline \multicolumn{6}{|l|}{ 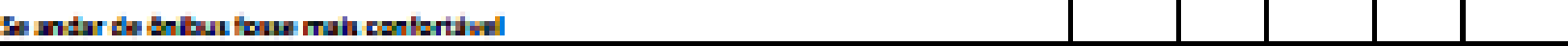 } \\
\hline \multicolumn{6}{|l|}{ 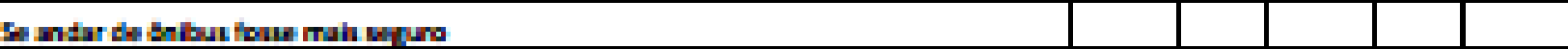 } \\
\hline 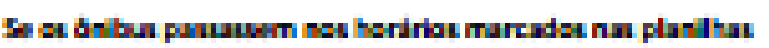 & & & & & \\
\hline
\end{tabular}




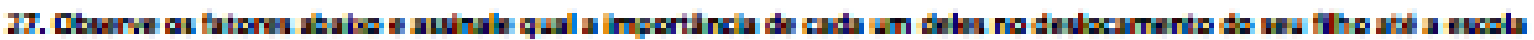

\begin{tabular}{|c|c|c|c|c|}
\hline & $\begin{array}{l}\text { kJod } \\
\text { inpertarin }\end{array}$ & $\begin{array}{l}\text { Feucs } \\
\text { Inpertante }\end{array}$ & Importanir & $\begin{array}{l}\text { Huts } \\
\text { Inpertunte }\end{array}$ \\
\hline \multicolumn{5}{|l|}{ 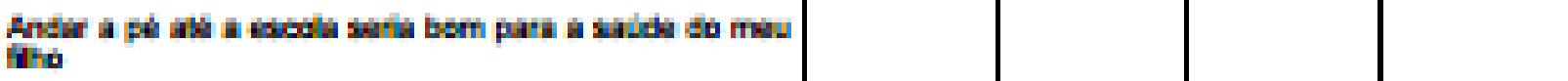 } \\
\hline \multicolumn{5}{|l|}{ 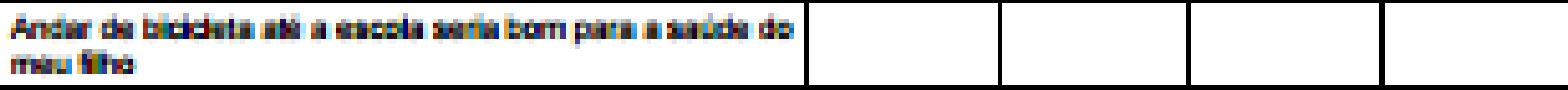 } \\
\hline \multicolumn{5}{|l|}{ 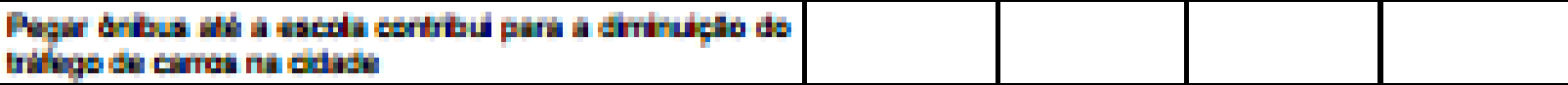 } \\
\hline \multicolumn{5}{|l|}{ 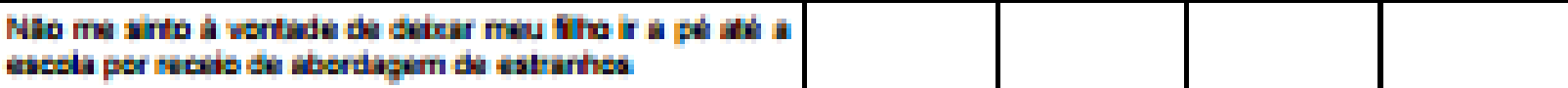 } \\
\hline \multicolumn{5}{|l|}{ 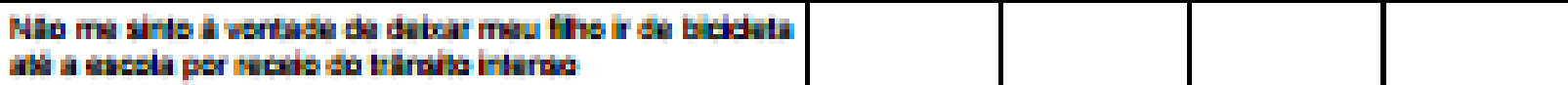 } \\
\hline \multicolumn{5}{|l|}{ 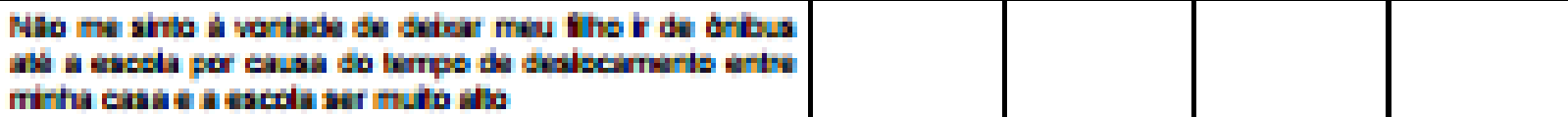 } \\
\hline \multicolumn{5}{|l|}{ 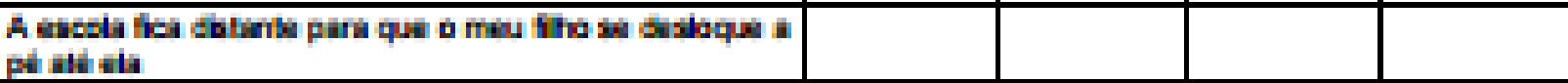 } \\
\hline \multicolumn{5}{|l|}{ 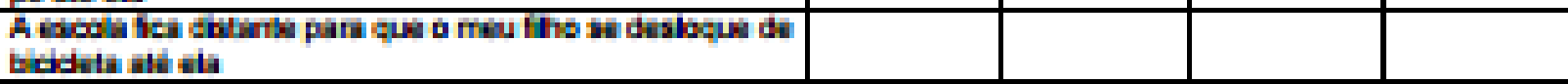 } \\
\hline \multicolumn{5}{|l|}{ 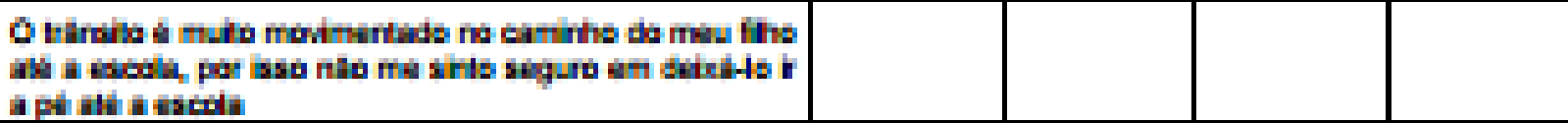 } \\
\hline \multicolumn{5}{|l|}{ 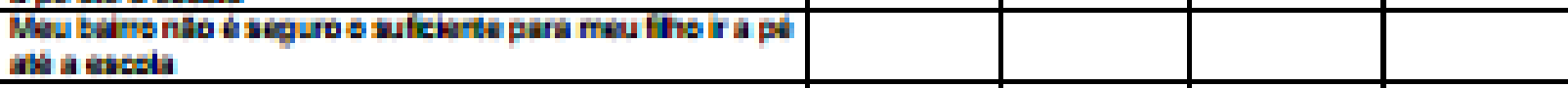 } \\
\hline \multicolumn{5}{|l|}{ 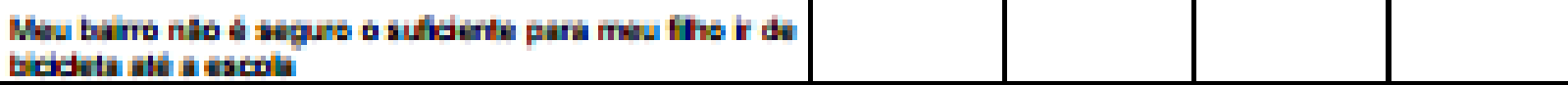 } \\
\hline \multicolumn{5}{|l|}{ 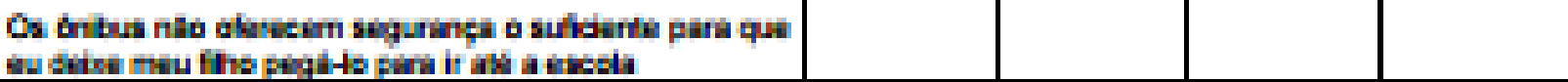 } \\
\hline \multicolumn{5}{|l|}{ 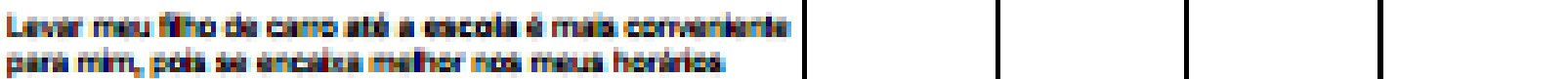 } \\
\hline \multicolumn{5}{|l|}{ 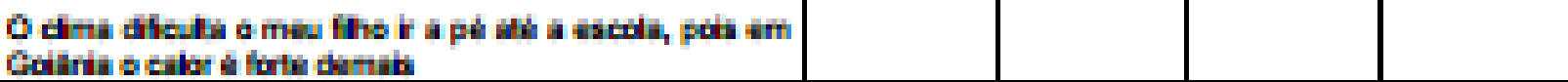 } \\
\hline \multicolumn{5}{|l|}{ 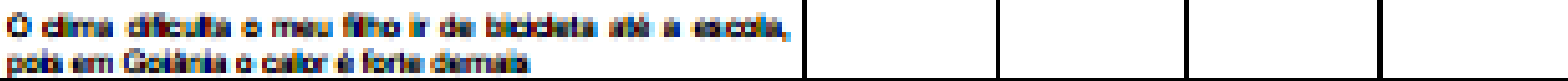 } \\
\hline \multicolumn{5}{|l|}{ 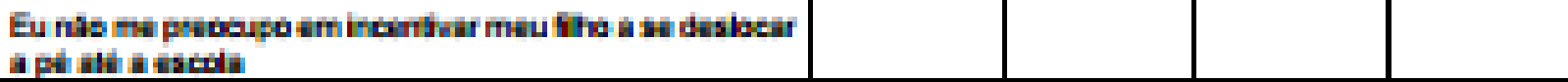 } \\
\hline \multicolumn{5}{|l|}{ 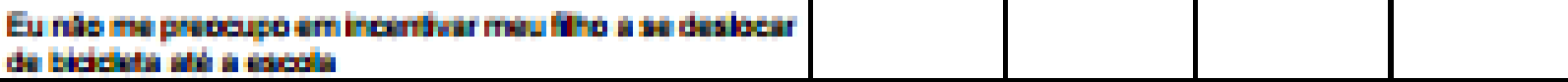 } \\
\hline \multicolumn{5}{|l|}{ 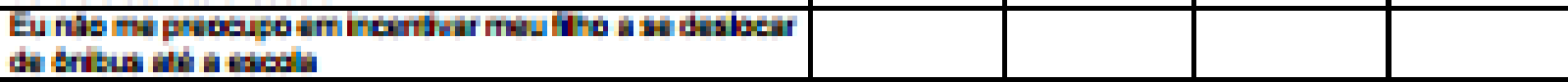 } \\
\hline \multicolumn{5}{|l|}{ 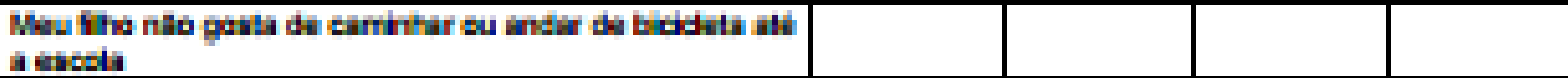 } \\
\hline \multicolumn{5}{|l|}{ 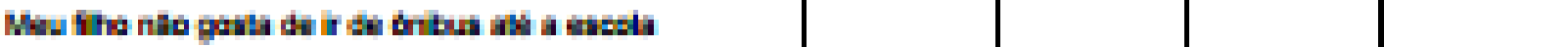 } \\
\hline \multicolumn{5}{|l|}{ 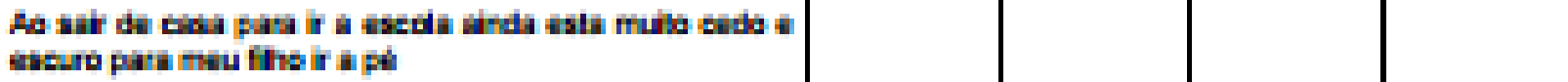 } \\
\hline \multicolumn{5}{|l|}{ 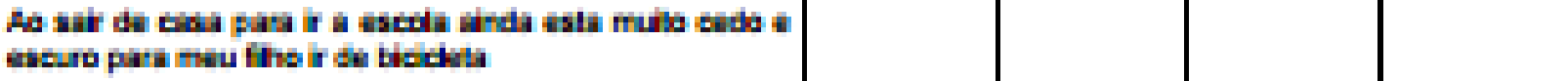 } \\
\hline 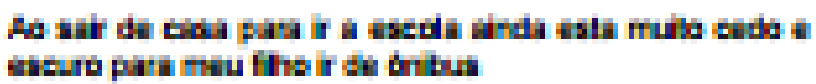 & & & & \\
\hline
\end{tabular}




\section{A.4 Escolas e Bairros Pesquisados}

\begin{tabular}{|c|c|c|c|c|c|c|}
\hline \multicolumn{7}{|c|}{ ANEXO A-4 NOME E ENDEREÇO DAS ESCOLAS PESQUISADAS } \\
\hline \multirow{2}{*}{ Região } & \multicolumn{2}{|c|}{ Estadual } & \multicolumn{2}{|c|}{ Municipal } & \multicolumn{2}{|c|}{ Particular } \\
\hline & Escola & Endereço & Escola & Endereço & Escola & Endereço \\
\hline \multirow[t]{2}{*}{$\begin{array}{c}\text { Campinas } \\
\text { Centro }\end{array}$} & $\begin{array}{c}\text { COLEGIO } \\
\text { APLICACA } \\
\text { O DO } \\
\text { INSTITUTO } \\
\text { DE } \\
\text { EDUCACAO } \\
\text { DE GOIAS }\end{array}$ & $\begin{array}{c}\text { RUA 159, } \\
176 \text { - VILA } \\
\text { NOVA }\end{array}$ & \multirow[t]{2}{*}{$\begin{array}{c}\text { ESCOLA } \\
\text { MUNICIPAL } \\
\text { SANTA } \\
\text { HELENA }\end{array}$} & \multirow[t]{2}{*}{$\begin{array}{l}\text { Av. Curitiba } \\
\text { VILA } \\
\text { PARAISO }\end{array}$} & \multirow[t]{2}{*}{$\begin{array}{c}\text { COLEGIO } \\
\text { ANHANGUE } \\
\text { RA }\end{array}$} & \multirow{2}{*}{$\begin{array}{c}\text { Rua } \\
\text { professor } \\
\text { Lázaro } \\
\text { Costa } \\
\text { CIDADE } \\
\text { JARDIM }\end{array}$} \\
\hline & \begin{tabular}{|c|} 
COLEGIO \\
ESTADUAL \\
ASSIS \\
CHATEAUB \\
RIAND
\end{tabular} & $\begin{array}{l}\text { Av. Otavio } \\
\text { Tavares de } \\
\text { Morais S/N } \\
\text { CAMPINAS }\end{array}$ & & & & \\
\hline Leste & $\begin{array}{c}\text { COLEGIO } \\
\text { ESTADUAL } \\
\text { MAJOR } \\
\text { OSCAR } \\
\text { ALVELOS }\end{array}$ & $\begin{array}{c}\text { RUA } 2011 \text { - } \\
\text { PARQUE } \\
\text { ATHENEU }\end{array}$ & $\begin{array}{c}\text { ESCOLA } \\
\text { MUNICIPAL } \\
\text { ANA DAS } \\
\text { NEVES }\end{array}$ & \begin{tabular}{|c|} 
Rua C6 \\
Quad. 08 Lt \\
06 PARQUE \\
DAS \\
LARANJEIR \\
AS \\
\end{tabular} & $\begin{array}{c}\text { COLEGIO } \\
\text { ADVENTIST } \\
\text { A NOVO } \\
\text { MUNDO }\end{array}$ & $\begin{array}{c}\text { Rua Indiana } \\
\text { JARDIM } \\
\text { NOVO } \\
\text { MUNDO }\end{array}$ \\
\hline Noroeste & $\begin{array}{c}\text { COLEGIO } \\
\text { ESTADUAL } \\
\text { NOSSA } \\
\text { SENHORA } \\
\text { DE } \\
\text { LOURDES }\end{array}$ & $\begin{array}{c}\text { Rua JC } 26 \text { - } \\
\text { JD } \\
\text { CURTIBA ॥ }\end{array}$ & $\begin{array}{c}\text { CENTRO } \\
\text { PROMOCIO } \\
\text { NAL } \\
\text { TODOS OS } \\
\text { SANTOS II }\end{array}$ & $\begin{array}{c}\text { Rua Gaspar } \\
\text { Silveira } \\
\text { Martins } \\
\text { CAPUAVA }\end{array}$ & $\begin{array}{l}\text { COLEGIO } \\
\text { PROJETO } \\
\text { DIDATICO }\end{array}$ & $\begin{array}{c}\text { Rua I } \\
\text { PARQUE } \\
\text { TREMENDÃ } \\
\text { O }\end{array}$ \\
\hline \multirow[t]{2}{*}{ Norte } & \multirow{2}{*}{$\begin{array}{c}\text { COLEGIO } \\
\text { ESTADUAL } \\
\text { WALDEMA } \\
\text { R MUNDIM }\end{array}$} & \multirow{2}{*}{$\begin{array}{c}\text { Rua R } 40 \\
\text { Qd } 40 \text { Lt } 28 \\
\text { CONJ } \\
\text { TAATIAIA I }\end{array}$} & $\begin{array}{c}\text { ESC MUL } \\
\text { STEPHANIA } \\
\text { ALVES } \\
\text { BISPO } \\
\end{array}$ & \begin{tabular}{|c|} 
Rua \\
Transversal \\
Qd. 74 \\
JARDIM \\
LIBERDADE \\
\end{tabular} & \multirow{2}{*}{\begin{tabular}{|c|} 
\\
COLEGIO \\
INTEGRADO \\
DE \\
EDUCACAO \\
MODERNA
\end{tabular}} & \multirow[t]{2}{*}{$\begin{array}{l}\text { Rua J } 6 \text { - } \\
\text { SETOR JAO }\end{array}$} \\
\hline & & & $\begin{array}{c}\text { ESCOLA } \\
\text { MUNICIPAL } \\
\text { MARIA DA } \\
\text { TERRA } \\
\end{array}$ & $\begin{array}{c}\text { Rua BF } 1 \text { A } \\
\text { BAIRRO } \\
\text { FLORESTA }\end{array}$ & & \\
\hline \multirow{2}{*}{ Oeste } & $\begin{array}{c}\text { COLEGIO } \\
\text { ESTADUAL } \\
\text { LUIS } \\
\text { PERILLO }\end{array}$ & $\begin{array}{c}\text { Rua } \\
\text { Humberto } \\
\text { Dias - } \\
\text { BAIRRO } \\
\text { GOIA } \\
\end{array}$ & \multirow{2}{*}{$\begin{array}{c}\text { ESC MUL } \\
\text { CASTORIN } \\
\text { A } \\
\text { BITENCOU } \\
\text { RT ALVES }\end{array}$} & \multirow{2}{*}{$\begin{array}{c}\text { Rua CP } 8 \text { - } \\
\text { CAROLINA } \\
\text { PARQUE }\end{array}$} & \multirow{2}{*}{$\begin{array}{c}\text { EDUCANDA } \\
\text { RIO } \\
\text { PEQUENOS } \\
\text { GENIOS }\end{array}$} & \multirow{2}{*}{$\begin{array}{c}\text { Rua VC } 70 \\
\text { Qd.140 } \\
\text { Lt17/18 - } \\
\text { CONJUNTO } \\
\text { VERA } \\
\text { CRUZ }\end{array}$} \\
\hline & $\begin{array}{c}\text { COLEGIO } \\
\text { ESTADUAL } \\
\text { SENADOR } \\
\text { TEOTONIO } \\
\text { VILELA } \\
\end{array}$ & $\begin{array}{c}\text { Av. } \\
\text { Senador } \\
\text { Canedo SN } \\
\text { CJ. VERA } \\
\text { CRUZ I } \\
\end{array}$ & & & & \\
\hline \multirow[t]{2}{*}{ Sudoeste } & \multirow{2}{*}{$\begin{array}{c}\text { ESCOLA } \\
\text { ESTADUAL } \\
\text { PROFESSO } \\
\mathrm{R} \\
\text { SEBASTIAO } \\
\text { FRANCA }\end{array}$} & \multirow{2}{*}{$\begin{array}{c}\text { Rua } \\
\text { Presidente } \\
\text { Cleveland, } \\
\text { QD38, LT.8 } \\
\text { JD } \\
\text { PRESIDENT } \\
\text { E }\end{array}$} & $\begin{array}{c}\text { ESCOLA } \\
\text { MUNICIPAL } \\
\text { ENGENHEIR } \\
\text { O ANTONIO } \\
\text { FELIX DA } \\
\text { SILVA } \\
\end{array}$ & $\begin{array}{c}\text { Rua } \\
\text { Dinamarca } \\
\text { S/N qd. } 99 \\
\text { JARDIM } \\
\text { EUROPA }\end{array}$ & \multirow{2}{*}{$\begin{array}{c}\text { ESCOLA } \\
\text { JESUS } \\
\text { MARIA } \\
\text { JOSÉ }\end{array}$} & \multirow{2}{*}{$\begin{array}{c}\text { Rua F } 29 \\
\text { SETOR } \\
\text { FAIÇALV ILL } \\
\text { E }\end{array}$} \\
\hline & & & \begin{tabular}{|c|} 
ESCOLA \\
MUNICIPAL \\
DEP. JAMEL \\
CECÍLIO
\end{tabular} & $\begin{array}{c}\text { AV. Pedro } \\
\text { Ludovico } \\
\text { Teixeira } \\
\text { JARDIM } \\
\text { VILA BOA } \\
\end{array}$ & & \\
\hline Sul & $\begin{array}{c}\text { COLEGIO } \\
\text { ESTADUAL } \\
\text { VISCONDE } \\
\text { DE MAUA }\end{array}$ & $\begin{array}{c}\text { Rua } 1016 \\
\text { com rua } \\
1007 \text { - } \\
\text { SETOR } \\
\text { PEDRO } \\
\text { LUDOVICO }\end{array}$ & $\begin{array}{c}\text { ESCOLA } \\
\text { MUNICIPAL } \\
\text { ZABEL } \\
\text { ESPIRIDIAO } \\
\text { JORGE }\end{array}$ & $\begin{array}{c}\text { Rua São } \\
\text { Luis, } 499 \\
\text { quadra } 10 \\
\text { ALTO DA } \\
\text { GLÓRIA }\end{array}$ & $\begin{array}{c}\text { Escola } \\
\text { Interamérica }\end{array}$ & $\begin{array}{c}\text { Rua C } 242 \\
\text { JARDIM } \\
\text { AMÉRICA }\end{array}$ \\
\hline
\end{tabular}


Anexo

$$
\text { B }
$$




\section{B.1 Tabela de Probabilidades}

\begin{tabular}{|r|r|r|r|r|}
\hline Indivíduo & Outros & A pé & Bicicleta & ônibus \\
\hline 1 & 0.068432 & 0.832185 & 0.030649 & 0.068734 \\
\hline 2 & 0.41138 & 0.309691 & 0.018743 & 0.260185 \\
\hline 3 & 0.12504 & 0.180349 & 0.012317 & 0.682294 \\
\hline 4 & 0.207412 & 0.296391 & 0.016125 & 0.480072 \\
\hline 5 & 0.341141 & 0.651442 & 0.006734 & 0.000683 \\
\hline 6 & 0.835182 & 0.081954 & 0.003564 & 0.0793 \\
\hline 7 & 0.07551 & 0.781731 & 0.016806 & 0.125952 \\
\hline 8 & 0.207412 & 0.296391 & 0.016125 & 0.480072 \\
\hline 9 & 0.247592 & 0.357841 & 0.022659 & 0.371907 \\
\hline 10 & 0.273125 & 0.435643 & 0.01536 & 0.275871 \\
\hline 11 & 0.640227 & 0.331229 & 0.005232 & 0.023312 \\
\hline 12 & 0.138692 & 0.21877 & 0.073832 & 0.568707 \\
\hline 13 & 0.08166 & 0.633926 & 0.022978 & 0.261436 \\
\hline 14 & 0.075678 & 0.847094 & 0.018667 & 0.058561 \\
\hline 15 & 0.090045 & 0.100065 & 0.018507 & 0.791383 \\
\hline 16 & 0.386827 & 0.522574 & 0.022452 & 0.068147 \\
\hline 17 & 0.075623 & 0.709399 & 0.027389 & 0.187589 \\
\hline 18 & 0.065112 & 0.385054 & 0.032473 & 0.517361 \\
\hline 19 & 0.306382 & 0.648379 & 0.028305 & 0.016934 \\
\hline 20 & 0.377133 & 0.60231 & 0.011766 & 0.008791 \\
\hline 21 & 0.105969 & 0.188541 & 0.020041 & 0.685449 \\
\hline 22 & 0.077318 & 0.123098 & 0.052153 & 0.747431 \\
\hline 23 & 0.885838 & 0.038368 & $1.94 \mathrm{E}+05$ & 0.075794 \\
\hline 24 & 0.042418 & 0.431419 & 0.030025 & 0.496138 \\
\hline 25 & 0.037975 & 0.226672 & 0.023998 & 0.711356 \\
\hline 26 & 0.331362 & 0.584165 & 0.070788 & 0.013685 \\
\hline 27 & 0.075623 & 0.709399 & 0.027389 & 0.187589 \\
\hline 28 & 0.176811 & 0.311675 & 0.02639 & 0.485125 \\
\hline 29 & 0.668058 & 0.265667 & 0.025435 & 0.040841 \\
\hline 30 & 0.075623 & 0.709399 & 0.027389 & 0.187589 \\
\hline 31 & 0.042378 & 0.272593 & 0.014873 & 0.670156 \\
\hline 32 & 0.058652 & 0.861891 & 0.033811 & 0.045645 \\
\hline 33 & 0.079284 & 0.879257 & 0.015434 & 0.026024 \\
\hline 34 & 0.243922 & 0.290368 & 0.043849 & 0.421861 \\
\hline 35 & 0.226237 & 0.44493 & 0.021372 & 0.307462 \\
\hline 36 & 0.086348 & 0.227121 & 0.030607 & 0.655924 \\
\hline 37 & 0.513887 & 0.026153 & $3.23 \mathrm{E}+05$ & 0.45996 \\
\hline 38 & 0.878257 & 0.044018 & $6.85 \mathrm{E}+05$ & 0.077725 \\
\hline 39 & 0.103233 & 0.226198 & 0.084613 & 0.585957 \\
\hline 40 & 0.246476 & 0.717856 & 0.027669 & 0.007999 \\
\hline 41 & 0.086348 & 0.227121 & 0.030607 & 0.655924 \\
\hline 43 & 0.086348 & 0.227121 & 0.030607 & 0.655924 \\
\hline & & & & \\
\hline
\end{tabular}




\begin{tabular}{|r|r|r|r|r|}
\hline 44 & 0.893782 & 0.060023 & $2.18 \mathrm{E}+05$ & 0.046195 \\
\hline 45 & 0.629042 & 0.286793 & 0.067293 & 0.016872 \\
\hline 46 & 0.187814 & 0.31057 & 0.051984 & 0.449632 \\
\hline 47 & 0.584384 & 0.024775 & $8.49 \mathrm{E}+05$ & 0.39084 \\
\hline 48 & 0.038591 & 0.380552 & 0.012815 & 0.568043 \\
\hline 49 & 0.038591 & 0.380552 & 0.012815 & 0.568043 \\
\hline 50 & 0.038591 & 0.380552 & 0.012815 & 0.568043 \\
\hline 51 & 0.038591 & 0.380552 & 0.012815 & 0.568043 \\
\hline 52 & 0.859579 & 0.073418 & 0.00221 & 0.064792 \\
\hline 53 & 0.103233 & 0.226198 & 0.084613 & 0.585957 \\
\hline 54 & 0.848462 & 0.051048 & $2.86 \mathrm{E}+04$ & 0.10049 \\
\hline 55 & 0.602788 & 0.277389 & 0.081707 & 0.038115 \\
\hline 56 & 0.65484 & 0.180965 & 0.038697 & 0.125498 \\
\hline 57 & 0.086348 & 0.227121 & 0.030607 & 0.655924 \\
\hline 58 & 0.735006 & 0.058597 & $7.35 \mathrm{E}+05$ & 0.206397 \\
\hline 59 & 0.59123 & 0.337649 & 0.054349 & 0.016773 \\
\hline 60 & 0.77484 & 0.20533 & 0.005496 & 0.014335 \\
\hline 61 & 0.023927 & 0.949521 & 0.022924 & 0.003628 \\
\hline 62 & 0.570479 & 0.388756 & 0.035716 & 0.005049 \\
\hline 63 & 0.564649 & 0.367556 & 0.019737 & 0.048058 \\
\hline 64 & 0.258747 & 0.531763 & 0.016378 & 0.193112 \\
\hline 65 & 0.897839 & 0.082297 & 0.001791 & 0.018073 \\
\hline 66 & 0.085723 & 0.555114 & 0.043288 & 0.315875 \\
\hline 67 & 0.693364 & 0.167698 & 0.010514 & 0.128423 \\
\hline 68 & 0.294823 & 0.695427 & 0.008672 & 0.001078 \\
\hline 69 & 0.324929 & 0.648314 & 0.017781 & 0.008976 \\
\hline 70 & 0.793077 & 0.046097 & $4.70 \mathrm{E}+05$ & 0.160826 \\
\hline 71 & 0.885429 & 0.03884 & $1.77 \mathrm{E}+05$ & 0.075731 \\
\hline 72 & 0.304608 & 0.652853 & 0.02571 & 0.016829 \\
\hline 73 & 0.412937 & 0.519408 & 0.031116 & 0.036538 \\
\hline 74 & 0.085723 & 0.555114 & 0.043288 & 0.315875 \\
\hline 75 & 0.105924 & 0.190868 & 0.018302 & 0.684906 \\
\hline 76 & 0.412937 & 0.519408 & 0.031116 & 0.036538 \\
\hline 77 & 0.388552 & 0.493298 & 0.037099 & 0.081052 \\
\hline 78 & 0.059333 & 0.568946 & 0.024876 & 0.346845 \\
\hline 79 & 0.349248 & 0.482291 & 0.023466 & 0.144995 \\
\hline 80 & 0.067892 & 0.836161 & 0.02778 & 0.068167 \\
\hline 81 & 0.053987 & 0.810971 & 0.036028 & 0.099014 \\
\hline 82 & 0.897839 & 0.082297 & 0.001791 & 0.018073 \\
\hline 83 & 0.885429 & 0.03884 & $1.77 \mathrm{E}+05$ & 0.075731 \\
\hline 86 & 0.33092 & 0.590832 & 0.064587 & 0.013661 \\
\hline & 0.667271 & 0.268741 & 0.02321 & 0.040777 \\
\hline 0.0370082 & 0.335404 & 0.143157 & 0.381357 \\
\hline & 0.0361 & 0.864973 & 0.061622 & 0.037306 \\
\hline & & & \\
\hline
\end{tabular}




\begin{tabular}{|r|r|r|r|r|}
\hline 90 & 0.03912 & 0.603941 & 0.053158 & 0.303781 \\
\hline 91 & 0.056427 & 0.849983 & 0.075212 & 0.018377 \\
\hline 92 & 0.040114 & 0.894768 & 0.044393 & 0.020726 \\
\hline 93 & 0.048399 & 0.740278 & 0.051904 & 0.15942 \\
\hline 94 & 0.15699 & 0.819206 & 0.022372 & 0.001432 \\
\hline 95 & 0.056427 & 0.849983 & 0.075212 & 0.018377 \\
\hline 96 & 0.091693 & 0.869585 & 0.032182 & 0.00654 \\
\hline 97 & 0.043435 & 0.939097 & 0.015842 & 0.001626 \\
\hline 98 & 0.040114 & 0.894768 & 0.044393 & 0.020726 \\
\hline 99 & 0.472659 & 0.524689 & 0.002522 & 0.00013 \\
\hline 100 & 0.038264 & 0.861472 & 0.053655 & 0.046608 \\
\hline 101 & 0.0361 & 0.864973 & 0.061622 & 0.037306 \\
\hline 102 & 0.170261 & 0.797599 & 0.031161 & 0.00098 \\
\hline 103 & 0.026409 & 0.922791 & 0.046519 & 0.004281 \\
\hline 104 & 0.332568 & 0.631815 & 0.03196 & 0.003657 \\
\hline 105 & 0.026409 & 0.922791 & 0.046519 & 0.004281 \\
\hline 106 & 0.031752 & 0.918152 & 0.043454 & 0.006643 \\
\hline 107 & 0.053525 & 0.682003 & 0.132732 & 0.131739 \\
\hline 108 & 0.033576 & 0.812004 & 0.072621 & 0.081799 \\
\hline 109 & 0.163906 & 0.43311 & 0.102936 & 0.300049 \\
\hline 110 & 0.040114 & 0.894768 & 0.044393 & 0.020726 \\
\hline 111 & 0.036327 & 0.902614 & 0.031304 & 0.029755 \\
\hline 112 & 0.033576 & 0.812004 & 0.072621 & 0.081799 \\
\hline 113 & 0.178525 & 0.810632 & 0.010768 & $7.44 \mathrm{E}+09$ \\
\hline 114 & 0.508847 & 0.482262 & 0.006401 & 0.00249 \\
\hline 115 & 0.056427 & 0.849983 & 0.075212 & 0.018377 \\
\hline 116 & 0.076627 & 0.222298 & 0.04291 & 0.658165 \\
\hline 117 & 0.471496 & 0.487706 & 0.034499 & 0.006299 \\
\hline 118 & 0.026409 & 0.922791 & 0.046519 & 0.004281 \\
\hline 119 & 0.096886 & 0.310193 & 0.033341 & 0.55958 \\
\hline 120 & 0.170261 & 0.797599 & 0.031161 & 0.00098 \\
\hline 121 & 0.040114 & 0.894768 & 0.044393 & 0.020726 \\
\hline 122 & 0.617748 & 0.377909 & $7.26 \mathrm{E}+05$ & 0.004344 \\
\hline 123 & 0.025718 & 0.907051 & 0.057402 & 0.009828 \\
\hline 124 & 0.326239 & 0.625578 & 0.039726 & 0.008457 \\
\hline 125 & 0.0361 & 0.864973 & 0.061622 & 0.037306 \\
\hline 126 & 0.0361 & 0.864973 & 0.061622 & 0.037306 \\
\hline 127 & 0.035672 & 0.94067 & 0.021219 & 0.002439 \\
\hline 128 & 0.138958 & 0.836083 & 0.024821 & 0.000137 \\
\hline 129 & 0.15808 & 0.795474 & 0.044625 & 0.00182 \\
\hline 130 & 0.026409 & 0.922791 & 0.046519 & 0.004281 \\
\hline 131 & 0.150664 & 0.8344 & 0.014821 & 0.000115 \\
\hline 132 & 0.0361 & 0.864973 & 0.061622 & 0.037306 \\
\hline 134 & 0.026409 & 0.922791 & 0.046519 & 0.004281 \\
\hline & 0.045891 & 0.926243 & 0.019136 & 0.008729 \\
\hline & & & \\
\hline
\end{tabular}




\begin{tabular}{|c|c|c|c|c|}
\hline 136 & 0.26123 & 0.657618 & 0.074341 & 0.006811 \\
\hline 137 & 0.59195 & 0.3519 & 0.053775 & 0.002376 \\
\hline 138 & 0.680918 & 0.310884 & $2.56 E+06$ & 0.008198 \\
\hline 139 & 0.040114 & 0.894768 & 0.044393 & 0.020726 \\
\hline 140 & 0.439288 & 0.555221 & 0.004371 & 0.00112 \\
\hline 141 & 0.036327 & 0.902614 & 0.031304 & 0.029755 \\
\hline 142 & 0.486151 & 0.508491 & 0.003758 & 0.0016 \\
\hline 143 & 0.0361 & 0.864973 & 0.061622 & 0.037306 \\
\hline 144 & 0.043435 & 0.939097 & 0.015842 & 0.001626 \\
\hline 145 & 0.056427 & 0.849983 & 0.075212 & 0.018377 \\
\hline 146 & 0.056427 & 0.849983 & 0.075212 & \begin{tabular}{|l|l|}
0.018377 \\
\end{tabular} \\
\hline 147 & 0.125636 & 0.361104 & 0.055525 & 0.457736 \\
\hline 148 & 0.15808 & 0.795474 & 0.044625 & \begin{tabular}{|l|l|}
0.00182 \\
\end{tabular} \\
\hline 149 & 0.053525 & 0.682003 & 0.132732 & \\
\hline 150 & 0.032449 & 0.929625 & 0.035047 & 0.00288 \\
\hline 151 & 0.091693 & 0.869585 & 0.032182 & 0.00654 \\
\hline 152 & 0.662562 & 0.135238 & 0.012578 & 0.189622 \\
\hline 153 & 0.016305 & 0.085119 & 0.005755 & \begin{tabular}{|l}
0.892821 \\
\end{tabular} \\
\hline 154 & 0.083377 & 0.428647 & 0.036574 & \begin{tabular}{|l}
0.451403 \\
\end{tabular} \\
\hline 155 & 0.634708 & 0.091475 & 7.08 & 0.273818 \\
\hline 156 & 0.391541 & 0.601174 & 0.006134 & 0.001151 \\
\hline 157 & 0.208295 & 0.667966 & 0.018988 & 0.104751 \\
\hline 158 & 0.639962 & 0.121212 & 0.021874 & 0.216952 \\
\hline 159 & 0.036001 & 0.034989 & 0.004132 & 878 \\
\hline 160 & 0.016305 & 0.085119 & 0.005755 & 0.892821 \\
\hline 161 & 0.779157 & 0.203765 & 0.003946 & 0.013132 \\
\hline 162 & 0.740247 & 0.219384 & $7.42 E+05$ & 0.040369 \\
\hline 163 & 0.743994 & 0.034332 & $3.83 E+05$ & 0.221673 \\
\hline 164 & 0.042904 & 0.184854 & 0.027633 & 0.744609 \\
\hline 165 & 0.086253 & 0.835577 & 0.024196 & 0.053974 \\
\hline 166 & 0.092892 & 0.141427 & 0.016972 & 0.748709 \\
\hline 167 & 0.178248 & 0.204803 & 0.010998 & 0.605951 \\
\hline 168 & 0.694565 & 0.222084 & 0.020987 & 0.062364 \\
\hline 169 & 0.455773 & 0.455141 & 0.029833 & 0.059253 \\
\hline 170 & 0.690634 & 0.295164 & 0.001785 & 0.012418 \\
\hline 171 & 0.023311 & 0.025237 & 0.002084 & 0.949369 \\
\hline 172 & 0.073466 & 0.793786 & 0.013793 & 0.118954 \\
\hline 173 & 0.69295 & 0.172713 & 0.009703 & 0.124635 \\
\hline 174 & 0.632256 & 0.169455 & $2.46 \mathrm{E}+06$ & 0.198289 \\
\hline 175 & 0.023553 & 0.029991 & 0.003641 & 0.942815 \\
\hline 176 & 0.117682 & 0.232566 & 0.022855 & 0.626897 \\
\hline 177 & 0.076587 & 0.886434 & 0.012577 & 0.024403 \\
\hline 178 & 0.073466 & 0.793786 & 0.013793 & 0.118954 \\
\hline 179 & 0.073466 & 0.793786 & 0.013793 & 0.118954 \\
\hline 180 & 0.319133 & 0.656182 & 0.016125 & 0.008561 \\
\hline 181 & 0.092078 & 0.815701 & 0.0106 & 0.081621 \\
\hline
\end{tabular}




\begin{tabular}{|c|c|c|c|c|}
\hline 182 & 0.727686 & 0.232676 & 0.011772 & 0.027866 \\
\hline 183 & 0.073305 & 0.856376 & 0.015254 & 0.055065 \\
\hline 184 & 0.149574 & 0.581218 & 0.01657 & 0.252638 \\
\hline 185 & 0.063294 & 0.126251 & 0.015575 & 0.79488 \\
\hline 186 & 0.073305 & 0.856376 & 0.015254 & 0.055065 \\
\hline 187 & 0.177649 & 0.326829 & 0.022368 & 0.473154 \\
\hline 188 & 0.319535 & 0.302834 & 0.006992 & 0.370639 \\
\hline 189 & 0.063294 & 0.126251 & 0.015575 & 0.79488 \\
\hline 190 & 0.128673 & 0.793126 & 0.010352 & 0.06785 \\
\hline 191 & 0.05951 & 0.625843 & 0.028044 & 0.286603 \\
\hline 192 & 0.483283 & 0.376199 & 0.014659 & 0.125859 \\
\hline 193 & 0.042434 & 0.450432 & 0.025338 & 0.481795 \\
\hline 194 & 0.126819 & 0.190903 & 0.010538 & 0.67174 \\
\hline 195 & & 0.625843 & 0.028044 & \\
\hline 196 & 0.360402 & 0.417446 & 0.011949 & 0.210204 \\
\hline 197 & 0.051645 & 0.065152 & 0.006301 & 0.876902 \\
\hline 198 & 0.302358 & 0.544212 & 0.015898 & \\
\hline 199 & 0.063294 & 0.126251 & 0.015575 & 0.79488 \\
\hline 200 & 0.482997 & 0.488981 & 0.006524 & 0.021498 \\
\hline 201 & 0.052974 & 0.820038 & 0.032642 & \\
\hline 202 & 0.28602 & 0.701744 & 0.009843 & 0.002 \\
\hline 203 & 0.074053 & 0.725007 & 0.022625 & 0.178315 \\
\hline 204 & 0.574317 & 0.091378 & 0.005052 & 0.329253 \\
\hline 205 & 0.066576 & 0.069966 & 0.018783 & 0.844675 \\
\hline 206 & 0.693378 & 0.148066 & $8.92 \mathrm{E}+05$ & 0.158556 \\
\hline 207 & 0.663727 & 0.241504 & $9.56 \mathrm{E}+04$ & 0.094769 \\
\hline 208 & 0.292109 & 0.685606 & 0.016001 & 0.006284 \\
\hline 209 & 0.627819 & 0.360241 & 0.003042 & 0.008898 \\
\hline 210 & 0.183947 & 0.154755 & 0.011536 & 0.649762 \\
\hline 211 & 0.057544 & 0.690798 & 0.029398 & 0.222261 \\
\hline 212 & 0.057544 & 0.690798 & 0.029398 & 0.222261 \\
\hline 213 & 0.073445 & 0.167229 & 0.019593 & 0.739733 \\
\hline 214 & 0.061767 & 0.088948 & 0.00817 & 0.841115 \\
\hline 215 & 0.671811 & 0.264332 & 0.003155 & 0.060702 \\
\hline 216 & 0.515834 & 0.104358 & 0.00383 & 0.375977 \\
\hline 217 & 0.929576 & 0.057888 & $1.49 \mathrm{E}+04$ & 0.012536 \\
\hline 218 & 0.191356 & 0.733361 & 0.074154 & 0.001128 \\
\hline 219 & 0.237393 & 0.620132 & 0.140395 & 0.00208 \\
\hline 220 & 0.506306 & 0.47437 & 0.017357 & 0.001967 \\
\hline 221 & 0.500434 & 0.473246 & 0.021737 & 0.004583 \\
\hline 222 & 0.391632 & 0.580165 & 0.027077 & 0.001125 \\
\hline 223 & 0.052197 & 0.653148 & 0.118524 & 0.176131 \\
\hline 224 & 0.039565 & 0.775551 & 0.142999 & 0.041885 \\
\hline 225 & 0.51424 & 0.373795 & 0.104058 & 0.007907 \\
\hline 226 & 0.191356 & 0.733361 & 0.074154 & 0.001128 \\
\hline 227 & 0.029867 & 0.853779 & 0.111395 & 0.00496 \\
\hline
\end{tabular}




\begin{tabular}{|r|r|r|r|r|}
\hline 228 & 0.286672 & 0.659774 & 0.048431 & 0.005123 \\
\hline 229 & 0.605949 & 0.357906 & 0.028604 & 0.00754 \\
\hline 230 & 0.039565 & 0.775551 & 0.142999 & 0.041885 \\
\hline 231 & 0.174634 & 0.718923 & 0.104383 & 0.00206 \\
\hline 232 & 0.039565 & 0.775551 & 0.142999 & 0.041885 \\
\hline 233 & 0.506306 & 0.47437 & 0.017357 & 0.001967 \\
\hline 234 & 0.506306 & 0.47437 & 0.017357 & 0.001967 \\
\hline 235 & 0.520906 & 0.473062 & 0.005885 & 0.000147 \\
\hline 236 & 0.237393 & 0.620132 & 0.140395 & 0.00208 \\
\hline 237 & 0.56159 & 0.426542 & 0.010028 & 0.00184 \\
\hline 238 & 0.553403 & 0.429083 & 0.014739 & 0.002775 \\
\hline 239 & 0.052197 & 0.653148 & 0.118524 & 0.176131 \\
\hline 240 & 0.594249 & 0.289006 & 0.114303 & 0.002443 \\
\hline 241 & 0.043602 & 0.878095 & 0.062785 & 0.015519 \\
\hline 242 & 0.174634 & 0.718923 & 0.104383 & 0.00206 \\
\hline 243 & 0.200284 & 0.728827 & 0.068242 & 0.002647 \\
\hline 244 & 0.037292 & 0.874035 & 0.085283 & 0.00339 \\
\hline 245 & 0.039565 & 0.775551 & 0.142999 & 0.041885 \\
\hline 246 & 0.039565 & 0.775551 & 0.142999 & 0.041885 \\
\hline 247 & 0.56159 & 0.426542 & 0.010028 & 0.00184 \\
\hline 248 & 0.174634 & 0.718923 & 0.104383 & 0.00206 \\
\hline 249 & 0.068848 & 0.849667 & 0.065524 & 0.015961 \\
\hline 250 & 0.057273 & 0.847251 & 0.069903 & 0.025573 \\
\hline 251 & 0.247459 & 0.650312 & 0.092927 & 0.009302 \\
\hline 252 & 0.496318 & 0.419996 & 0.076893 & 0.006793 \\
\hline 253 & 0.265354 & 0.656014 & 0.069147 & 0.009485 \\
\hline 254 & 0.174634 & 0.718923 & 0.104383 & 0.00206 \\
\hline 255 & 0.273539 & 0.694776 & 0.028399 & 0.003287 \\
\hline 256 & 0.237139 & 0.62901 & 0.112836 & 0.021015 \\
\hline 257 & 0.271095 & 0.558312 & 0.163352 & 0.007241 \\
\hline 258 & 0.131195 & 0.787639 & 0.080923 & 0.000243 \\
\hline 259 & 0.614698 & 0.341447 & 0.041768 & 0.002087 \\
\hline 260 & 0.247459 & 0.650312 & 0.092927 & 0.009302 \\
\hline 261 & 0.206278 & 0.477681 & 0.239918 & 0.076124 \\
\hline 262 & 0.506306 & 0.47437 & 0.017357 & 0.001967 \\
\hline 263 & 0.039565 & 0.775551 & 0.142999 & 0.041885 \\
\hline 264 & 0.204925 & 0.73882 & 0.055106 & 0.001149 \\
\hline 265 & 0.721579 & 0.269521 & $5.74 \mathrm{E}+06$ & 0.0089 \\
\hline 266 & 0.033404 & 0.550559 & 0.353742 & 0.062295 \\
\hline 268 & 0.039565 & 0.775551 & 0.142999 & 0.041885 \\
\hline 270 & 0.065752 & 0.819023 & 0.07929 & 0.035935 \\
\hline 0.040879 & 0.516305 & 0.117618 & 0.325198 \\
\hline 0.246393 & 0.637689 & 0.115002 & 0.000916 \\
\hline 297405 & 0.686972 & 0.014814 & 0.00081 \\
\hline 22535 & 0.201448 & $9.70 \mathrm{E}+05$ & 0.076017 \\
\hline & & & \\
\hline 273 & 0.084103 & 0.64447 & 0.092572 & 0.178854 \\
\hline 2610
\end{tabular}




\begin{tabular}{|c|c|c|c|c|}
\hline 274 & 0.065137 & 0.873788 & 0.031996 & 0.029079 \\
\hline 275 & 0.102916 & 0.556393 & 0.014748 & 0.325943 \\
\hline 276 & 0.682929 & 0.207769 & 0.03253 & 0.076772 \\
\hline 277 & 0.0965 & 0.732624 & 0.083828 & 0.087048 \\
\hline 278 & 0.450279 & 0.523454 & 0.014357 & 0.011911 \\
\hline 279 & 0.568245 & 0.115645 & 0.009188 & 0.306921 \\
\hline 280 & 0.049486 & 0.871488 & 0.056809 & 0.022218 \\
\hline 281 & 0.625514 & 0.248338 & 0.109664 & 0.016484 \\
\hline 282 & 0.266522 & 0.675947 & 0.049034 & 0.008498 \\
\hline 283 & 0.843303 & 0.058003 & $1.09 \mathrm{E}+05$ & \\
\hline 284 & 0.743312 & 0.051603 & $1.22 \mathrm{E}+06$ & 0.205085 \\
\hline 285 & 0.355235 & 0.571686 & 0.064664 & 0.008416 \\
\hline 286 & 0.424124 & 0.382642 & 0.038481 & 0.154 \\
\hline 287 & 0.328701 & 0.635003 & 0.025876 & \\
\hline 288 & 0.084103 & 0.64447 & 0.092572 & 0.178854 \\
\hline 289 & 0.063407 & 0.637873 & 0.163109 & 0.13561 \\
\hline 290 & \begin{tabular}{|l|}
0.62092 \\
\end{tabular} & 0.105267 & 0.023217 & \\
\hline 291 & 0.363882 & 0.580186 & 0.052275 & 0.003657 \\
\hline 292 & 0.631809 & 0.182513 & 0.026461 & 0.159217 \\
\hline 293 & 0.067261 & 0.893928 & 0.026075 & \\
\hline 294 & 0.067261 & 0.893928 & 0.026075 & 0.012737 \\
\hline 295 & \begin{tabular}{|l|}
0.10514 \\
\end{tabular} & 0.879767 & 0.010733 & 0.00436 \\
\hline 296 & 0.204355 & 0.755825 & 0.038797 & 0.001 \\
\hline 297 & 0.764328 & 0.213536 & $9.53 \mathrm{E}+05$ & 0.02 \\
\hline 298 & 0.117934 & 0.746947 & 0.079884 & 0.055234 \\
\hline 299 & 0.450279 & 0.523454 & 0.014357 & 0.011911 \\
\hline 300 & 0.352583 & 0.57083 & 0.040753 & 0.035834 \\
\hline 301 & 0.069471 & 0.781006 & 0.050105 & 0.099418 \\
\hline 302 & 0.125852 & 0.863414 & 0.007877 & 0.002857 \\
\hline 303 & 0.077956 & 0.112928 & 0.022453 & 0.786662 \\
\hline 304 & 0.371483 & 0.501018 & 0.099287 & 0.028211 \\
\hline 305 & 0.077798 & 0.798789 & 0.02679 & 0.096623 \\
\hline 306 & \begin{tabular}{|l|}
0.24087 \\
\end{tabular} & 0.730431 & 0.02804 & 0.00066 \\
\hline 307 & 0.067511 & 0.837603 & 0.029922 & 0.064965 \\
\hline 308 & \begin{tabular}{|l|}
0.058667 \\
\end{tabular} & 0.855013 & 0.052325 & 0.033995 \\
\hline 309 & 0.910783 & 0.080996 & 0.002428 & 0.005793 \\
\hline 310 & 0.063407 & 0.637873 & 0.163109 & 0.13561 \\
\hline 311 & 0.729962 & 0.218708 & 0.043216 & 0.008114 \\
\hline 312 & 0.370385 & 0.564114 & 0.029707 & 0.035794 \\
\hline 313 & 0.701683 & 0.276066 & 0.011299 & 0.010952 \\
\hline 314 & 0.872255 & 0.101627 & 0.00585 & 0.020267 \\
\hline 315 & 0.145062 & 0.329183 & 0.066504 & 0.459251 \\
\hline 316 & 0.106893 & 0.683338 & 0.091744 & 0.118024 \\
\hline 317 & 0.060115 & 0.682134 & 0.054937 & 0.202813 \\
\hline 318 & 0.599583 & 0.385508 & 0.004926 & 0.009983 \\
\hline 319 & 0.046847 & 0.571009 & 0.066035 & 0.31611 \\
\hline
\end{tabular}




\begin{tabular}{|c|c|c|c|c|}
\hline 320 & 0.061017 & 0.881036 & 0.04295 & 0.014998 \\
\hline 321 & 0.709304 & 0.285731 & $7.75 \mathrm{E}+05$ & 0.004965 \\
\hline 322 & 0.077798 & 0.798789 & 0.02679 & 0.096623 \\
\hline 323 & 0.067511 & 0.837603 & 0.029922 & 0.064965 \\
\hline 324 & 0.603389 & 0.374116 & 0.00982 & 0.012675 \\
\hline 325 & 0.049486 & 0.871488 & 0.056809 & 0.022218 \\
\hline 326 & 0.046847 & 0.571009 & 0.066035 & 0.31611 \\
\hline 327 & 0.363882 & 0.580186 & 0.052275 & 0.003657 \\
\hline 328 & 0.65354 & 0.341335 & 0.002598 & 0.002527 \\
\hline 329 & 0.309875 & 0.668191 & 0.017647 & 0.004287 \\
\hline 330 & 0.636576 & 0.359477 & 0.002805 & 0.001142 \\
\hline 331 & 0.364651 & 0.616939 & 0.012914 & 0.005496 \\
\hline 332 & 0.355235 & 0.571686 & 0.064664 & 0.00 \\
\hline 333 & 0.259239 & 0.723594 & 0.01662 & \\
\hline 334 & 0.049486 & 0.871488 & 0.056809 & 0.022218 \\
\hline 335 & 0.046847 & 0.571009 & 0.066035 & 0.31611 \\
\hline 336 & 0.085496 & 0.779173 & 0.032118 & \\
\hline 337 & 0.308385 & 0.440589 & 0.037228 & 0.213799 \\
\hline 338 & 0.24087 & 0.730431 & 0.02804 & 0.00066 \\
\hline 339 & 0.278836 & 0.21 & 0.048901 & \\
\hline 340 & 0.872255 & 0.101627 & 0.00585 & 0.020267 \\
\hline 341 & 0.080076 & 0.887846 & 0.024206 & 0.007873 \\
\hline 342 & 0.061017 & 0.881036 & 0.04295 & 0.014998 \\
\hline 343 & 0.709304 & 0.285731 & $7.75 E+05$ & 0.00 \\
\hline 344 & 0.073183 & 0.518666 & 0.072682 & 0.335468 \\
\hline 345 & 0.843303 & 0.058003 & $1.09 E+05$ & 0.098694 \\
\hline 346 & 0.067261 & 0.893928 & 0.026075 & 0.012737 \\
\hline 347 & 0.081711 & 0.890395 & 0.019423 & 0.008471 \\
\hline 348 & 0.200583 & 0.7488 & 0.048252 & 0.002365 \\
\hline 349 & 0.266522 & 0.675947 & 0.049034 & 0.008498 \\
\hline 350 & 0.664884 & 0.280098 & 0.028736 & 0.026282 \\
\hline 351 & 0.84683 & 0.099586 & 0.007197 & 0.046387 \\
\hline 352 & 0.603389 & 0.374116 & 0.00982 & 0.012675 \\
\hline 353 & 0.631809 & 0.182513 & 0.026461 & 0.159217 \\
\hline 354 & 0.286021 & 0.675304 & 0.034115 & 0.00456 \\
\hline 355 & 0.673187 & 0.318587 & 0.004355 & 0.003871 \\
\hline 356 & 0.701683 & 0.276066 & 0.011299 & 0.010952 \\
\hline 357 & 0.744935 & 0.248335 & $6.33 E+05$ & 0.00673 \\
\hline 358 & 0.363882 & 0.580186 & 0.052275 & 0.003657 \\
\hline 359 & 0.629854 & 0.300177 & 0.047754 & 0.022214 \\
\hline 360 & 0.246407 & 0.677695 & 0.068524 & 0.007373 \\
\hline 361 & 0.163167 & 0.735868 & 0.090382 & 0.010582 \\
\hline 362 & 0.239233 & 0.553229 & 0.194928 & 0.012611 \\
\hline 363 & 0.571428 & 0.402221 & 0.025179 & 0.001171 \\
\hline 364 & 0.228288 & 0.657291 & 0.113711 & 0.00071 \\
\hline 365 & 0.037875 & 0.908996 & 0.050909 & 0.002221 \\
\hline
\end{tabular}




\begin{tabular}{|r|r|r|r|r|}
\hline 366 & 0.367076 & 0.604956 & 0.027085 & 0.000883 \\
\hline 367 & 0.805903 & 0.169558 & 0.018741 & 0.005798 \\
\hline 368 & 0.564679 & 0.403594 & 0.020019 & 0.011707 \\
\hline 369 & 0.676 & 0.246133 & 0.029911 & 0.047956 \\
\hline 370 & 0.854944 & 0.135748 & 0.006714 & 0.002594 \\
\hline 371 & 0.049581 & 0.690206 & 0.12015 & 0.140063 \\
\hline 372 & 0.160576 & 0.735409 & 0.10243 & 0.001585 \\
\hline 373 & 0.612859 & 0.377102 & $4.32 \mathrm{E}+06$ & 0.010039 \\
\hline 374 & 0.854944 & 0.135748 & 0.006714 & 0.002594 \\
\hline 375 & 0.786517 & 0.069464 & $1.72 \mathrm{E}+06$ & 0.144019 \\
\hline 376 & 0.328668 & 0.57359 & 0.090434 & 0.007307 \\
\hline 377 & 0.58211 & 0.3825 & 0.029326 & 0.006064 \\
\hline 378 & 0.055553 & 0.761608 & 0.167322 & 0.015517 \\
\hline 379 & 0.050628 & 0.777805 & 0.075394 & 0.096172 \\
\hline 380 & 0.597748 & 0.199049 & 0.054534 & 0.14867 \\
\hline 381 & 0.039621 & 0.887686 & 0.060887 & 0.011806 \\
\hline 382 & 0.590415 & 0.390241 & $6.42 \mathrm{E}+06$ & 0.019343 \\
\hline 383 & 0.246407 & 0.677695 & 0.068524 & 0.007373 \\
\hline 384 & 0.571428 & 0.402221 & 0.025179 & 0.001171 \\
\hline 385 & 0.858242 & 0.075098 & $1.49 \mathrm{E}+05$ & 0.06666 \\
\hline 386 & 0.571428 & 0.402221 & 0.025179 & 0.001171 \\
\hline 387 & 0.663385 & 0.218863 & 0.047765 & 0.069987 \\
\hline 388 & 0.305042 & 0.646338 & 0.042729 & 0.00589 \\
\hline 389 & 0.246407 & 0.677695 & 0.068524 & 0.007373 \\
\hline 390 & 0.171263 & 0.737 & 0.089744 & 0.001993 \\
\hline 391 & 0.848576 & 0.137545 & 0.00994 & 0.00394 \\
\hline 392 & 0.49032 & 0.464409 & 0.044917 & 0.000354 \\
\hline 393 & 0.266267 & 0.681743 & 0.048006 & 0.003984 \\
\hline 394 & 0.246407 & 0.677695 & 0.068524 & 0.007373 \\
\hline 395 & 0.694263 & 0.269309 & $6.74 \mathrm{E}+06$ & 0.036428 \\
\hline 396 & 0.279114 & 0.699158 & 0.021015 & 0.000713 \\
\hline 397 & 0.158791 & 0.605817 & 0.234221 & 0.001171 \\
\hline 398 & 0.338336 & 0.585002 & 0.073471 & 0.003191 \\
\hline 399 & 0.164499 & 0.781241 & 0.052972 & 0.001287 \\
\hline 400 & 0.119923 & 0.800951 & 0.07894 & 0.000186 \\
\hline 401 & 0.158791 & 0.605817 & 0.234221 & 0.001171 \\
\hline 402 & 0.321636 & 0.623202 & 0.034533 & 0.020629 \\
\hline 403 & 0.44413 & 0.461283 & 0.093605 & 0.000982 \\
\hline 404 & 0.591686 & 0.401796 & $2.56 \mathrm{E}+06$ & 0.006517 \\
\hline 406 & 0.160576 & 0.735409 & 0.10243 & 0.001585 \\
\hline 407 & 0.222523 & 0.717966 & 0.054802 & 0.004709 \\
\hline & 0.56907 & 0.287423 & 0.133554 & 0.009953 \\
\hline 0.160576 & 0.735409 & 0.10243 & 0.001585 \\
\hline 0.18978 & 0.784285 & 0.025867 & $6.79 \mathrm{E}+09$ \\
\hline 328288 & 0.657291 & 0.113711 & 0.00071 \\
\hline & 0.553229 & 0.194928 & 0.012611 \\
\hline
\end{tabular}




\begin{tabular}{|r|r|r|r|r|}
\hline 412 & 0.571507 & 0.309211 & 0.117315 & 0.001967 \\
\hline 413 & 0.571428 & 0.402221 & 0.025179 & 0.001171 \\
\hline 414 & 0.371464 & 0.606526 & 0.021631 & 0.000379 \\
\hline 415 & 0.577634 & 0.35022 & 0.058626 & 0.01352 \\
\hline 416 & 0.228288 & 0.657291 & 0.113711 & 0.00071 \\
\hline 417 & 0.299422 & 0.65761 & 0.037694 & 0.005275 \\
\hline 418 & 0.650395 & 0.31249 & 0.025834 & 0.011281 \\
\hline 419 & 0.799425 & 0.171118 & $2.07 \mathrm{E}+06$ & 0.029456 \\
\hline 420 & 0.290644 & 0.571204 & 0.1305 & 0.007652 \\
\hline 421 & 0.615325 & 0.368019 & 0.005336 & 0.011321 \\
\hline 422 & 0.396007 & 0.57642 & 0.013356 & 0.014217 \\
\hline 423 & 0.3153 & 0.671216 & 0.013082 & 0.000402 \\
\hline 424 & 0.253374 & 0.714729 & 0.03113 & 0.000767 \\
\hline 425 & 0.396007 & 0.57642 & 0.013356 & 0.014217 \\
\hline 426 & 0.292585 & 0.648593 & 0.046671 & 0.012151 \\
\hline 427 & 0.299422 & 0.65761 & 0.037694 & 0.005275 \\
\hline 428 & 0.747523 & 0.19608 & $1.25 \mathrm{E}+06$ & 0.056397 \\
\hline 429 & 0.315436 & 0.651725 & 0.027555 & 0.005284 \\
\hline 430 & 0.368282 & 0.551322 & 0.070755 & 0.009641 \\
\hline 431 & 0.272744 & 0.708164 & 0.018455 & 0.000636 \\
\hline 432 & 0.343035 & 0.616447 & 0.028501 & 0.012018 \\
\hline 433 & 0.704918 & 0.265701 & 0.01746 & 0.01192 \\
\hline 434 & 0.609485 & 0.272721 & 0.061798 & 0.055996 \\
\hline 435 & 0.279924 & 0.68482 & 0.027439 & 0.007817 \\
\hline 436 & 0.651945 & 0.321057 & 0.023035 & 0.003963 \\
\hline 437 & 0.799425 & 0.171118 & $2.07 \mathrm{E}+06$ & 0.029456 \\
\hline 438 & 0.3153 & 0.671216 & 0.013082 & 0.000402 \\
\hline 439 & 0.799425 & 0.171118 & $2.07 \mathrm{E}+06$ & 0.029456 \\
\hline 440 & 0.641162 & 0.344256 & 0.00714 & 0.007441 \\
\hline 441 & 0.901541 & 0.059262 & $4.90 \mathrm{E}+05$ & 0.039197 \\
\hline 442 & 0.382505 & 0.529603 & 0.066308 & 0.021584 \\
\hline 443 & 0.660122 & 0.327772 & $2.26 \mathrm{E}+06$ & 0.012106 \\
\hline 444 & 0.641144 & 0.238259 & 0.008767 & 0.11183 \\
\hline 445 & 0.328816 & 0.653454 & 0.015597 & 0.002132 \\
\hline 446 & 0.774064 & 0.201164 & $1.02 \mathrm{E}+06$ & 0.024772 \\
\hline 447 & 0.922311 & 0.045041 & $5.00 \mathrm{E}+05$ & 0.032647 \\
\hline 448 & 0.447675 & 0.534268 & 0.009258 & 0.008799 \\
\hline 449 & 0.631549 & 0.34226 & 0.008912 & 0.017279 \\
\hline 450 & 0.380542 & 0.598895 & 0.014224 & 0.006338 \\
\hline 451 & 0.738839 & 0.20592 & 0.046167 & 0.009074 \\
\hline 453 & 0.377944 & 0.560554 & 0.057306 & 0.004197 \\
\hline & 0.07296 & 0.481002 & 0.076478 & 0.369559 \\
\hline 455 & 0.531916 & 0.451571 & 0.011947 & 0.004566 \\
\hline 0.275221 & 0.740464 & 0.043125 & 0.001189 \\
\hline & 0.865449 & 0.059877 & 0.003849 & 0.070825 \\
\hline & & & \\
\hline
\end{tabular}




\begin{tabular}{|r|r|r|r|r|}
\hline 458 & 0.762505 & 0.234266 & $5.39 \mathrm{E}+05$ & 0.003229 \\
\hline 459 & 0.502401 & 0.447481 & 0.03321 & 0.016908 \\
\hline 460 & 0.377944 & 0.560554 & 0.057306 & 0.004197 \\
\hline 461 & 0.377944 & 0.560554 & 0.057306 & 0.004197 \\
\hline 462 & 0.700896 & 0.218906 & 0.021654 & 0.058544 \\
\hline 463 & 0.799425 & 0.171118 & $2.07 \mathrm{E}+06$ & 0.029456 \\
\hline 464 & 0.355551 & 0.590945 & 0.026655 & 0.02685 \\
\hline 465 & 0.377944 & 0.560554 & 0.057306 & 0.004197 \\
\hline 466 & 0.799425 & 0.171118 & $2.07 \mathrm{E}+06$ & 0.029456 \\
\hline 467 & 0.670135 & 0.191847 & $6.50 \mathrm{E}+06$ & 0.138018 \\
\hline 468 & 0.377944 & 0.560554 & 0.057306 & 0.004197 \\
\hline 469 & 0.640075 & 0.283761 & 0.05122 & 0.024944 \\
\hline 470 & 0.634451 & 0.307675 & 0.031931 & 0.025942 \\
\hline 471 & 0.481216 & 0.400118 & 0.036368 & 0.082298 \\
\hline 472 & 0.298305 & 0.573509 & 0.039079 & 0.089107 \\
\hline 473 & 0.469325 & 0.353593 & 0.057717 & 0.119365 \\
\hline 474 & 0.315436 & 0.651725 & 0.027555 & 0.005284 \\
\hline 475 & 0.395782 & 0.526878 & 0.027523 & 0.049817 \\
\hline 476 & 0.838012 & 0.053617 & $1.14 \mathrm{E}+06$ & 0.108372 \\
\hline 477 & 0.704607 & 0.187587 & 0.024581 & 0.083225 \\
\hline 478 & 0.356616 & 0.615301 & 0.024313 & 0.003771 \\
\hline 479 & 0.393198 & 0.47266 & 0.097966 & 0.036175 \\
\hline 480 & 0.683701 & 0.270365 & 0.031329 & 0.014606 \\
\hline 481 & 0.10342 & 0.699812 & 0.083748 & 0.11302 \\
\hline 482 & 0.288132 & 0.651322 & 0.049416 & 0.01113 \\
\hline 483 & 0.037478 & 0.286844 & 0.019013 & 0.656665 \\
\hline 484 & 0.393198 & 0.47266 & 0.097966 & 0.036175 \\
\hline 485 & 0.288132 & 0.651322 & 0.049416 & 0.01113 \\
\hline 486 & 0.10342 & 0.699812 & 0.083748 & 0.11302 \\
\hline 487 & 0.392258 & 0.532489 & 0.029329 & 0.045925 \\
\hline 488 & 0.06147 & 0.661631 & 0.063747 & 0.213152 \\
\hline 489 & 0.126298 & 0.546347 & 0.021668 & 0.305687 \\
\hline 490 & 0.278553 & 0.635547 & 0.060532 & 0.025367 \\
\hline 491 & 0.090419 & 0.878189 & 0.020036 & 0.011356 \\
\hline 492 & 0.615555 & 0.377878 & 0.004124 & 0.002443 \\
\hline 493 & 0.051331 & 0.813244 & 0.069604 & 0.065822 \\
\hline 494 & 0.076392 & 0.626316 & 0.033898 & 0.263394 \\
\hline 495 & 0.706511 & 0.180225 & 0.02177 & 0.091494 \\
\hline 496 & 0.668508 & 0.31805 & $2.02 \mathrm{E}+05$ & 0.013442 \\
\hline 497 & 0.293794 & 0.682316 & 0.020075 & 0.003816 \\
\hline 503 & 0.373987 & 0.539669 & 0.040296 & 0.046048 \\
\hline 503 & 0.338619 & 0.644786 & 0.014187 & 0.002408 \\
\hline & 0.396252 & 0.288721 & 0.054537 & 0.26049 \\
\hline & 0.309129 & 0.650529 & 0.034372 & 0.00597 \\
\hline & 0.172422 & 0.00604 & 0.019126 \\
\hline & 0.264756 & 0.038513 & 0.033407 \\
\hline
\end{tabular}




\begin{tabular}{|c|c|c|c|c|}
\hline 504 & 0.612941 & 0.20183 & $2.27 \mathrm{E}+06$ & 0.185229 \\
\hline 505 & 0.779172 & 0.052135 & 0.003878 & 0.164815 \\
\hline 506 & 0.547776 & 0.441461 & 0.008576 & 0.002187 \\
\hline 507 & 0.175046 & 0.745738 & 0.037325 & 0.041891 \\
\hline 508 & 0.904105 & 0.041828 & $3.68 \mathrm{E}+05$ & 0.054067 \\
\hline 509 & 0.379827 & 0.544819 & 0.064453 & 0.010901 \\
\hline 510 & 0.733129 & 0.237698 & 0.020598 & \\
\hline 511 & 0.731372 & 0.254097 & 0.008665 & 0.005866 \\
\hline 512 & 0.392258 & 0.532489 & 0.029329 & 0.045925 \\
\hline 513 & 0.642553 & 0.326353 & 0.028736 & \\
\hline 514 & 0.051331 & 0.813244 & 0.069604 & 0.065822 \\
\hline 515 & 0.06147 & 0.661631 & 0.063747 & 0.213152 \\
\hline 516 & 0.404045 & 0.515379 & 0.024817 & 5759 \\
\hline 517 & 0.302073 & 0.641614 & 0.042558 & \\
\hline 518 & 0.278334 & 0.698911 & 0.021078 & 0.001677 \\
\hline 519 & 0.748669 & 0.199931 & 0.041319 & 0.010081 \\
\hline 520 & 0.309129 & 0.650529 & 0.034372 & \\
\hline 521 & 0.542686 & 0.441441 & 0.010766 & 0.005107 \\
\hline 522 & 0.733967 & 0.235288 & 0.017518 & 0.013227 \\
\hline 523 & 0.359693 & 0.613615 & 0.020832 & \\
\hline 524 & 0.568176 & 0.024768 & $3.35 \mathrm{E}+04$ & 0.407056 \\
\hline 525 & 0.104703 & 0.856279 & 0.022923 & 0.016096 \\
\hline 526 & 0.624292 & 0.160739 & 0.024374 & 0.190595 \\
\hline 527 & 0.748669 & 0.199931 & 0.041319 & 081 \\
\hline 528 & 0.146024 & 0.762339 & 0.020085 & 0.071552 \\
\hline 529 & 0.06147 & 0.661631 & 0.063747 & 0.213152 \\
\hline 530 & 0.706511 & 0.180225 & .02177 & 0.091494 \\
\hline 531 & 0.064419 & 0.836797 & 0.053561 & 0.045223 \\
\hline 532 & 0.385322 & 0.545054 & 0.019147 & 0.050478 \\
\hline 533 & 0.725358 & 0.235254 & 0.009825 & 0.029564 \\
\hline 534 & 0.914916 & 0.060289 & 0.00566 & 0.019135 \\
\hline 535 & 0.878543 & 0.091234 & 0.005493 & 0.02473 \\
\hline 536 & 0.046832 & 0.508783 & 0.061538 & 0.382846 \\
\hline 537 & 0.127142 & 0.802079 & 0.022509 & 0.048271 \\
\hline 538 & 0.091255 & 0.827385 & 0.023118 & 0.058242 \\
\hline 539 & 0.094546 & 0.77674 & 0.038976 & 0.089738 \\
\hline 540 & 0.288132 & 0.651322 & 0.049416 & 0.01113 \\
\hline 541 & 0.06147 & 0.661631 & 0.063747 & 0.213152 \\
\hline 542 & 0.146867 & 0.529254 & 0.058263 & 0.265615 \\
\hline 543 & 0.054613 & 0.857238 & 0.058444 & 0.029705 \\
\hline 544 & 0.074481 & 0.746313 & 0.050076 & 0.12913 \\
\hline 545 & 0.338619 & 0.644786 & 0.014187 & 0.002408 \\
\hline 546 & 0.92675 & 0.060504 & 0.004525 & 0.008222 \\
\hline 547 & 0.288132 & 0.651322 & 0.049416 & 0.01113 \\
\hline 548 & 0.10342 & 0.699812 & 0.083748 & 0.11302 \\
\hline 549 & 0.288132 & 0.651322 & 0.049416 & 0.01113 \\
\hline
\end{tabular}




\begin{tabular}{|r|r|r|r|r|}
\hline 550 & 0.617654 & 0.264815 & 0.055314 & 0.062216 \\
\hline 551 & 0.041985 & 0.32549 & 0.054637 & 0.577888 \\
\hline 552 & 0.454029 & 0.42983 & 0.068847 & 0.047294 \\
\hline 553 & 0.688996 & 0.301828 & 0.004571 & 0.004605 \\
\hline 554 & 0.427091 & 0.485363 & 0.028007 & 0.059538 \\
\hline 555 & 0.478232 & 0.475965 & 0.014109 & 0.031695 \\
\hline 556 & 0.351124 & 0.5664 & 0.059639 & 0.022837 \\
\hline 557 & 0.351124 & 0.5664 & 0.059639 & 0.022837 \\
\hline 558 & 0.359048 & 0.482484 & 0.141018 & 0.01745 \\
\hline 559 & 0.578383 & 0.352241 & 0.033443 & 0.035933 \\
\hline 560 & 0.734962 & 0.261537 & 0.00236 & 0.001141 \\
\hline 561 & 0.378166 & 0.567894 & 0.041643 & 0.012298 \\
\hline 562 & 0.737894 & 0.143104 & $4.94 \mathrm{E}+06$ & 0.119001 \\
\hline 563 & 0.118053 & 0.57005 & 0.094676 & 0.217221 \\
\hline 564 & 0.098064 & 0.82896 & 0.035097 & 0.037879 \\
\hline 565 & 0.118053 & 0.57005 & 0.094676 & 0.217221 \\
\hline 566 & 0.442579 & 0.379654 & 0.109207 & 0.068559 \\
\hline 567 & 0.658719 & 0.262197 & 0.012541 & 0.066543 \\
\hline 568 & 0.639284 & 0.195592 & 0.0567 & 0.108424 \\
\hline 569 & 0.098064 & 0.82896 & 0.035097 & 0.037879 \\
\hline 570 & 0.088783 & 0.700615 & 0.036329 & 0.174273 \\
\hline 571 & 0.088221 & 0.810215 & 0.057331 & 0.044232 \\
\hline 572 & 0.113693 & 0.735605 & 0.028525 & 0.122176 \\
\hline 573 & 0.446449 & 0.432484 & 0.033059 & 0.088008 \\
\hline 574 & 0.048823 & 0.19942 & 0.072846 & 0.67891 \\
\hline 575 & 0.813107 & 0.035693 & 0.005695 & 0.145505 \\
\hline 576 & 0.070741 & 0.452638 & 0.168003 & 0.308617 \\
\hline 577 & 0.041985 & 0.32549 & 0.054637 & 0.577888 \\
\hline 578 & 0.062725 & 0.452694 & 0.052921 & 0.431661 \\
\hline 579 & 0.119592 & 0.828874 & 0.026245 & 0.02529 \\
\hline 580 & 0.027423 & 0.149778 & 0.013778 & 0.80902 \\
\hline 581 & 0.693438 & 0.300965 & 0.003631 & 0.001966 \\
\hline 582 & 0.414545 & 0.563292 & 0.017201 & 0.004963 \\
\hline 583 & 0.062725 & 0.452694 & 0.052921 & 0.431661 \\
\hline 584 & 0.081466 & 0.75516 & 0.067081 & 0.096293 \\
\hline 585 & 0.027423 & 0.149778 & 0.013778 & 0.80902 \\
\hline 586 & 0.291177 & 0.264594 & 0.032452 & 0.411777 \\
\hline 587 & 0.937769 & 0.043689 & 0.004534 & 0.014008 \\
\hline 588 & 0.351124 & 0.5664 & 0.059639 & 0.022837 \\
\hline 589 & 0.118053 & 0.57005 & 0.094676 & 0.217221 \\
\hline 590 & 0.085212 & 0.609304 & 0.056739 & 0.248745 \\
\hline 591 & 0.911827 & 0.062905 & 0.003661 & 0.021608 \\
\hline 592 & 0.715159 & 0.262553 & 0.006967 & 0.015322 \\
\hline 593 & 0.426663 & 0.439354 & 0.045529 & 0.088453 \\
\hline 59 & 0.140198 & 0.128402 & 0.058712 & 0.672688 \\
\hline & & & & \\
\hline
\end{tabular}




\begin{tabular}{|c|c|c|c|c|}
\hline 596 & 0.688594 & 0.271554 & 0.010346 & 0.029506 \\
\hline 597 & 0.085212 & 0.609304 & 0.056739 & 0.248745 \\
\hline 598 & 0.771044 & 0.192945 & 0.011463 & 0.024548 \\
\hline 599 & 0.06326 & 0.715205 & 0.084953 & 0.136582 \\
\hline 600 & 0.789439 & 0.138698 & $7.72 E+05$ & 0.071864 \\
\hline 601 & 0.70776 & 0.256521 & 0.031347 & 0.004373 \\
\hline 602 & 0.364055 & 0.603349 & 0.024636 & 0.007961 \\
\hline 603 & 0.333699 & 0.543316 & 0.071817 & 0.051168 \\
\hline 604 & 0.085212 & 0.609304 & 0.056739 & 0.248745 \\
\hline 605 & 0.461414 & 0.46793 & 0.061198 & 0.009458 \\
\hline 606 & 0.088783 & 0.700615 & 0.036329 & 0.174273 \\
\hline 607 & 0.378166 & 0.567894 & 0.041643 & 0.012298 \\
\hline 608 & 0.034776 & 0.158225 & 0.040403 & 0.766596 \\
\hline 609 & 0.089064 & 0.434083 & 0.090505 & \\
\hline 610 & 0.162398 & 0.094204 & 0.011371 & 0.732027 \\
\hline 611 & 0.715428 & 0.180105 & 0.006754 & 0.097714 \\
\hline 612 & 0.048187 & 0.311205 & 0.145006 & \\
\hline 613 & 0.715159 & 0.262553 & 0.006967 & 0.015322 \\
\hline 614 & 0.045207 & 0.825102 & 0.064703 & 0.064989 \\
\hline 615 & 0.507 & 0.476027 & 0.01 & \\
\hline 616 & 0.490355 & 0.505724 & 0.003578 & 0.000342 \\
\hline 617 & 0.621577 & 0.366193 & 0.010163 & 0.002067 \\
\hline 618 & 0.396696 & 0.535921 & 0.036546 & 0.030838 \\
\hline 619 & 0.202373 & 0.440431 & 3105 & 091 \\
\hline 620 & 0.045207 & 0.825102 & 0.064703 & 0.064989 \\
\hline 621 & 0.650115 & 0.274826 & 0.056615 & 0.018444 \\
\hline 622 & 0.29219 & 0.691029 & 0.012013 & 0.004768 \\
\hline 623 & 0.827797 & 0.093923 & 0.005686 & 0.072594 \\
\hline 624 & 0.045207 & 0.825102 & 0.064703 & 0.064989 \\
\hline 625 & 0.21142 & 0.754443 & 0.032444 & 0.00 \\
\hline 626 & 0.656799 & 0.231945 & $1.67 \mathrm{E}+06$ & 0.111256 \\
\hline 627 & 0.196623 & 0.753688 & 0.046541 & 0.003149 \\
\hline 628 & 0.277801 & 0.669451 & 0.051346 & 0.001402 \\
\hline 629 & 0.146267 & 0.817638 & 0.035727 & 0.000367 \\
\hline 630 & 0.54382 & 0.326317 & 0.122665 & 0.007198 \\
\hline 631 & 0.045207 & 0.825102 & 0.064703 & 0.064989 \\
\hline 632 & 0.756389 & 0.205695 & 0.025118 & 0.012798 \\
\hline 633 & 0.704384 & 0.162029 & 0.043517 & 0.09007 \\
\hline 634 & 0.050922 & 0.865226 & 0.047251 & 0.036601 \\
\hline 635 & 0.277801 & 0.669451 & 0.051346 & 0.001402 \\
\hline 636 & 0.196641 & 0.742254 & 0.040418 & 0.020687 \\
\hline 637 & 0.040874 & 0.900328 & 0.046903 & 0.011896 \\
\hline 638 & 0.21142 & 0.754443 & 0.032444 & 0.001693 \\
\hline 639 & 0.048571 & 0.738502 & 0.160751 & 0.052175 \\
\hline 640 & 0.071199 & 0.816969 & 0.079574 & 0.032258 \\
\hline 641 & 0.099931 & 0.876486 & 0.014972 & 0.008611 \\
\hline
\end{tabular}




\begin{tabular}{|c|c|c|c|c|}
\hline 642 & 0.286814 & 0.645221 & 0.060608 & 0.007356 \\
\hline 643 & 0.248493 & 0.727036 & 0.023382 & 0.001089 \\
\hline 644 & 0.116041 & 0.838296 & 0.03415 & 0.011513 \\
\hline 645 & 0.210416 & 0.671898 & 0.115168 & 0.002518 \\
\hline 646 & 0.047573 & 0.815879 & 0.055935 & 0.080613 \\
\hline 647 & 0.075857 & 0.871674 & 0.028589 & 0.023881 \\
\hline 648 & 0.277801 & 0.669451 & 0.051346 & \\
\hline 649 & 0.73285 & 0.254876 & $2.31 E+06$ & 0.012274 \\
\hline 650 & 0.313235 & 0.600662 & 0.074743 & 0.01 \\
\hline 651 & 0.071199 & 0.816969 & 0.079574 & \\
\hline 652 & 0.048064 & 0.901297 & 0.027408 & 0.023231 \\
\hline 653 & 0.630692 & 0.346861 & 0.01179 & 0.010657 \\
\hline 654 & 0.233117 & 0.752716 & 0.01348 & 0.00 \\
\hline 655 & 0.871429 & 0.118221 & 0.003788 & \\
\hline 656 & 0.196623 & 0.753688 & 0.046541 & 0.003149 \\
\hline 657 & 0.528433 & 0.384186 & 0.065314 & 0.022068 \\
\hline 658 & 0.059016 & 0.820481 & 0.036142 & \\
\hline 659 & 0.192063 & 0.743082 & 0.057603 & 0.00 \\
\hline 660 & 0.040874 & 0.900328 & 0.046903 & 0.011896 \\
\hline 661 & 0.544 & 0.392416 & 0.053142 & \\
\hline 662 & 0.146267 & 0.817638 & 0.035727 & 0.00 \\
\hline 663 & 0.641535 & 0.298407 & $7.59 \mathrm{E}+06$ & 0.060058 \\
\hline 664 & 0.045895 & .86865 & 0.033161 & 0.052295 \\
\hline 665 & 0.876631 & 499 & 0.002555 & 315 \\
\hline 666 & 0.118862 & 0.342775 & 0.205417 & 0.33 \\
\hline 667 & 0.045207 & 0.825102 & 0.064703 & 0.064989 \\
\hline 668 & 0.835845 & 0.147188 & 0.007213 & 0.00 \\
\hline 669 & 0.277801 & 0.669451 & 0.051346 & 0.001402 \\
\hline 670 & 0.047573 & 0.815879 & 0.055935 & 0.080613 \\
\hline 671 & 0.065395 & 0.700483 & 0.08356 & 0.150562 \\
\hline 672 & 0.050922 & 0.865226 & 0.047251 & 0.036601 \\
\hline 673 & 0.573836 & 0.384792 & 0.03629 & 0.005082 \\
\hline 674 & 0.221728 & 0.766929 & 0.011214 & 0.000129 \\
\hline 675 & 0.292362 & 0.595953 & 0.100534 & 0.011152 \\
\hline 676 & 0.621577 & 0.366193 & 0.010163 & 0.002067 \\
\hline 677 & 0.192063 & 0.743082 & 0.057603 & 0.007251 \\
\hline 678 & 0.21142 & 0.754443 & 0.032444 & 0.001693 \\
\hline 679 & 0.666421 & 0.307116 & $6.22 \mathrm{E}+06$ & 0.026463 \\
\hline 680 & 0.648688 & 0.334076 & $1.70 \mathrm{E}+06$ & 0.017236 \\
\hline 681 & \begin{tabular}{|l|}
0.08265 \\
\end{tabular} & 0.884146 & 0.020195 & 0.013009 \\
\hline 682 & 0.277801 & 0.669451 & 0.051346 & 0.001402 \\
\hline 683 & 0.055146 & 0.916715 & 0.021369 & 0.006769 \\
\hline 684 & 0.520114 & 0.315005 & 0.148652 & 0.01623 \\
\hline 685 & 0.188028 & 0.716368 & 0.04897 & 0.046634 \\
\hline 686 & 0.046123 & 0.926486 & 0.023004 & 0.004387 \\
\hline 687 & 0.277801 & 0.669451 & 0.051346 & 0.001402 \\
\hline
\end{tabular}




\begin{tabular}{|c|c|c|c|c|}
\hline 688 & 0.667202 & 0.240422 & 0.06561 & 0.026766 \\
\hline 689 & 0.188028 & 0.716368 & 0.04897 & 0.046634 \\
\hline 690 & 0.662827 & 0.044396 & $8.78 \mathrm{E}+05$ & 0.292777 \\
\hline 691 & 0.544791 & 0.392416 & 0.053142 & 0.00965 \\
\hline 692 & 0.280222 & 0.651073 & 0.03664 & 0.032066 \\
\hline 693 & 0.210416 & 0.671898 & 0.115168 & 0.002518 \\
\hline 694 & 0.286814 & 0.645221 & 0.060608 & 0.007356 \\
\hline 695 & 0.248493 & 0.727036 & 0.023382 & 0.001089 \\
\hline 696 & 0.651639 & 0.295087 & 0.049636 & 0.003638 \\
\hline 697 & 0.906417 & 0.07111 & $5.09 \mathrm{E}+05$ & 0.022472 \\
\hline 698 & 0.043342 & 0.665142 & 0.181756 & 0.10976 \\
\hline 699 & 0.221728 & 0.766929 & 0.011214 & 0.000129 \\
\hline 700 & 0.21142 & 0.754443 & 0.032444 & 0.001693 \\
\hline 701 & 0.695993 & 0.293883 & $1.12 \mathrm{E}+05$ & 0.010124 \\
\hline 702 & 0.21142 & 0.754443 & 0.032444 & 0.001693 \\
\hline 703 & 0.69449 & 0.289943 & $9.47 \mathrm{E}+05$ & 0.015567 \\
\hline 704 & 0.322481 & 0.669842 & 0.00711 & \\
\hline 705 & 0.504924 & 0.435641 & 0.00916 & 0.050275 \\
\hline 706 & 0.801109 & \begin{tabular}{|l|l|}
0.19539 \\
\end{tabular} & 0.002409 & 0.001091 \\
\hline 707 & 0.947791 & 0.039114 & 0.00031 & \\
\hline 708 & 0.944976 & 0.051532 & 0.000518 & 0.002974 \\
\hline 709 & 0.963531 & 0.035156 & 0.000502 & 0.000811 \\
\hline 710 & \begin{tabular}{|l|}
0.96645 \\
\end{tabular} & 0.027357 & 0.002974 & 0.003219 \\
\hline 711 & 0.954772 & 0.029742 & 0.001173 & 0.01 \\
\hline 712 & 0.961753 & 0.032681 & 0.00128 & 0.004286 \\
\hline 713 & 0.952796 & 0.04658 & 0.000155 & 0.000468 \\
\hline 714 & 0.990298 & 0.009098 & $6.66 \mathrm{E}+09$ & 0.00 \\
\hline 715 & 0.788847 & 0.208026 & 0.002629 & 0.000 \\
\hline 716 & 0.948014 & 0.022699 & 0.005428 & 0.023859 \\
\hline 717 & 0.942281 & 0.016114 & 0.000803 & 0.040802 \\
\hline 718 & 0.860783 & 0.136318 & 0.001251 & 0.001649 \\
\hline 719 & 0.971406 & 0.006826 & 0.000213 & 0.021555 \\
\hline 720 & 0.363292 & 0.598869 & 0.017109 & 0.020729 \\
\hline 721 & 0.841689 & 0.152202 & 0.002718 & 0.003391 \\
\hline 722 & 0.935721 & 0.014849 & 0.001435 & 0.047995 \\
\hline 723 & 0.431223 & 0.406059 & 0.045508 & 0.11721 \\
\hline 724 & 0.991341 & 0.004012 & $4.11 \mathrm{E}+04$ & 0.004647 \\
\hline 725 & 0.810346 & 0.180759 & 0.005024 & 0.003871 \\
\hline 726 & 0.971406 & 0.006826 & 0.000213 & 0.021555 \\
\hline 727 & 0.855284 & 0.129613 & 0.004056 & 0.011047 \\
\hline 728 & 0.965124 & 0.025268 & 0.00268 & 0.006928 \\
\hline 729 & 0.971406 & 0.006826 & 0.000213 & 0.021555 \\
\hline 730 & 0.831557 & 0.166289 & 0.001533 & 0.00062 \\
\hline 731 & 0.494585 & 0.421911 & 0.007622 & 0.075882 \\
\hline 732 & 0.983722 & 0.006849 & 0.00017 & 0.009259 \\
\hline 733 & 0.434439 & 0.504531 & 0.007899 & 0.053131 \\
\hline
\end{tabular}




\begin{tabular}{|c|c|c|c|c|}
\hline 734 & 0.839211 & 0.085487 & 0.001778 & 0.073524 \\
\hline 735 & 0.903934 & 0.07563 & 0.002655 & 0.01778 \\
\hline 736 & 0.943811 & 0.042496 & 0.00372 & 0.009973 \\
\hline 737 & 0.898081 & 0.097725 & 0.001175 & 0.003019 \\
\hline 738 & 0.942281 & 0.016114 & 0.000803 & 0.040802 \\
\hline 739 & 0.988518 & 0.006539 & $2.09 E+04$ & 0.004943 \\
\hline 740 & 0.343676 & 0.24799 & 0.009854 & 0.39848 \\
\hline 741 & 0.947152 & 0.051173 & 0.00041 & 0.001264 \\
\hline 742 & 0.986063 & 0.010754 & 0.000271 & 0.002912 \\
\hline 743 & 0.457293 & 0.098041 & 0.010898 & 0.433768 \\
\hline 744 & 0.961753 & 0.032681 & 0.00128 & 0.004286 \\
\hline 745 & 0.955231 & 0.025242 & 0.003361 & 0.016166 \\
\hline 746 & 0.267866 & .16252 & 0.022503 & 0.54 \\
\hline 747 & 0.810346 & 0.180759 & 0.005024 & \\
\hline 748 & 0.971406 & 0.006826 & 0.000213 & 0.021555 \\
\hline 749 & 0.855284 & 0.129613 & 0.004056 & 0.011047 \\
\hline 750 & 0.965124 & 0.025268 & 0.00268 & 0.006928 \\
\hline 751 & 0.971406 & 0.006826 & 0.000213 & 0.021555 \\
\hline 752 & 0.831557 & 0.166289 & 0.001533 & 0.00062 \\
\hline 753 & 0.494585 & 0.421911 & 0.00 & 882 \\
\hline 754 & 0.983722 & 0.006849 & .00017 & 0.005 \\
\hline 755 & 0.434439 & 0.504531 & 0.007899 & 0.053131 \\
\hline 756 & 0.839211 & 0.085487 & 0.001778 & 0.073524 \\
\hline 757 & 0.903934 & 0.07563 & 0.002655 & \\
\hline 758 & 0.943811 & 0.042496 & 0.00372 & 0.009973 \\
\hline 759 & 0.898081 & 0.097725 & 0.001175 & 0.003019 \\
\hline 760 & 0.942281 & 0.016114 & 0.000803 & 0.04 \\
\hline 761 & 0.988518 & 0.006539 & $2.09 \mathrm{E}+04$ & 0.004943 \\
\hline 762 & 0.343676 & 0.24799 & 0.009854 & 0.39848 \\
\hline 763 & 0.947152 & 0.051173 & 0.00041 & 0.00 \\
\hline 764 & 0.986063 & 0.010754 & 0.000271 & 0.002912 \\
\hline 765 & 0.457293 & 0.098041 & 0.010898 & 0.433768 \\
\hline 766 & 0.961753 & 0.032681 & 0.00128 & 0.004286 \\
\hline 767 & 0.955231 & 0.025242 & 0.003361 & 0.016166 \\
\hline 768 & 0.267866 & 0.16252 & 0.022503 & 0.547111 \\
\hline 769 & 0.835462 & 0.155276 & 0.001475 & 0.007787 \\
\hline 770 & 0.927605 & 0.070184 & 0.000332 & 0.001879 \\
\hline 771 & 0.988607 & 0.010728 & $5.80 E+09$ & 0.000606 \\
\hline 772 & 0.951077 & 0.047028 & 0.000491 & 0.001404 \\
\hline 773 & 0.806105 & 0.190034 & 0.001396 & 0.002465 \\
\hline 774 & 0.684004 & 0.311597 & 0.003621 & 0.000778 \\
\hline 775 & 0.840215 & 0.152611 & 0.003037 & 0.004138 \\
\hline 776 & 0.840215 & 0.152611 & 0.003037 & 0.004138 \\
\hline 777 & 0.927164 & 0.072072 & 0.000132 & 0.000632 \\
\hline 778 & 0.614103 & 0.159789 & 0.005089 & 0.221018 \\
\hline 779 & 0.873276 & 0.123883 & 0.000613 & 0.002228 \\
\hline
\end{tabular}




\begin{tabular}{|c|c|c|c|c|}
\hline 780 & 0.814596 & 0.182714 & 0.001153 & 0.001537 \\
\hline 781 & 0.940533 & 0.054699 & 0.001569 & 0.003199 \\
\hline 782 & 0.956406 & 0.038481 & 0.000498 & 0.004615 \\
\hline 783 & 0.983665 & 0.013986 & 0.000145 & 0.002204 \\
\hline 784 & 0.94932 & 0.029634 & 0.002915 & 0.018131 \\
\hline 785 & 0.977514 & 0.004815 & $2.48 \mathrm{E}+03$ & 0.017671 \\
\hline 786 & 0.949362 & 0.029874 & $2.53 \mathrm{E}+02$ & 0.020764 \\
\hline 787 & 0.9356 & 0.05492 & 0.001978 & 0.007503 \\
\hline 788 & 0.927605 & 0.070184 & 0.000332 & 0.001879 \\
\hline 789 & 0.360468 & 0.5312 & 0.008824 & \\
\hline 790 & 0.754098 & 0.083926 & 0.001259 & 0.160718 \\
\hline 791 & 0.977514 & 0.004815 & $2.48 \mathrm{E}+03$ & 0.017671 \\
\hline 792 & 0.983665 & 0.013986 & 0.000145 & 0.002204 \\
\hline 793 & 0.953839 & 0.042254 & 0.000681 & \\
\hline 794 & 0.759525 & 0.235064 & 0.003075 & 0.002336 \\
\hline 795 & 0.792232 & 0.206536 & 0.000783 & 0.000448 \\
\hline 796 & 0.960305 & 0.005145 & $1.72 \mathrm{E}+04$ & \\
\hline 797 & 0.834238 & 0.162316 & 0.002637 & 0.000809 \\
\hline 798 & 0.954227 & 0.042372 & 0.000305 & 0.003096 \\
\hline 799 & 0.953374 & 0.039061 & 0.000614 & \\
\hline 800 & 0.969978 & 0.025566 & 0.000238 & 0.004218 \\
\hline 801 & 0.940732 & 0.005615 & $1.31 \mathrm{E}+04$ & 0.053654 \\
\hline 802 & 0.956126 & 0.041964 & 0.000539 & 0.001372 \\
\hline 803 & 0.962523 & 0.035192 & 0.00 & 0.00 \\
\hline 804 & 0.745031 & 0.253766 & 0.001051 & 0.000152 \\
\hline 805 & 0.936123 & 0.059554 & 0.000982 & 0.003341 \\
\hline 806 & 0.891934 & 0.104217 & 0.001229 & 262 \\
\hline 807 & 0.953275 & 0.035391 & 0.000999 & 0.010335 \\
\hline 808 & 0.848302 & 0.146775 & 0.000971 & 0.003953 \\
\hline 809 & 0.976838 & 0.004934 & $6.99 \mathrm{E}+09$ & 0.018159 \\
\hline 810 & 0.976838 & 0.004934 & $6.99 E+09$ & 0.018159 \\
\hline 811 & 0.952668 & 0.019681 & 0.00077 & 0.026881 \\
\hline 812 & 0.952668 & 0.019681 & 0.00077 & 0.026881 \\
\hline 813 & 0.911899 & 0.002719 & $1.26 \mathrm{E}+02$ & 0.085382 \\
\hline 814 & 0.976838 & 0.004934 & $6.99 E+09$ & 0.018159 \\
\hline 815 & 0.965821 & 0.029098 & 0.000806 & 0.004275 \\
\hline 816 & 0.961388 & 0.016545 & 0.001798 & 0.02027 \\
\hline 817 & 0.982065 & 0.004132 & 0.000162 & 0.013641 \\
\hline 818 & 0.965821 & 0.029098 & 0.000806 & 0.004275 \\
\hline 819 & 0.952668 & 0.019681 & 0.00077 & 0.026881 \\
\hline 820 & 0.976838 & 0.004934 & $6.99 E+09$ & 0.018159 \\
\hline 821 & 0.959444 & 0.021875 & 0.000477 & 0.018204 \\
\hline 822 & 0.937866 & 0.003086 & $7.95 E+03$ & 0.059048 \\
\hline 823 & 0.982205 & 0.005475 & $4.32 E+09$ & 0.012277 \\
\hline 824 & 0.959444 & 0.021875 & 0.000477 & 0.018204 \\
\hline 825 & 0.959444 & 0.021875 & 0.000477 & 0.018204 \\
\hline
\end{tabular}




\begin{tabular}{|c|c|c|c|c|}
\hline 826 & 0.959444 & 0.021875 & 0.000477 & 0.018204 \\
\hline 827 & 0.986111 & 0.004579 & 0.0001 & 0.00921 \\
\hline 828 & 0.966819 & 0.018363 & 0.001111 & 0.013707 \\
\hline 829 & 0.959444 & 0.021875 & 0.000477 & 0.018204 \\
\hline 830 & 0.966819 & 0.018363 & 0.001111 & 0.013707 \\
\hline 831 & 0.959444 & 0.021875 & 0.000477 & 0.018204 \\
\hline 832 & 0.959444 & 0.021875 & 0.000477 & 0.018204 \\
\hline 833 & 0.959444 & 0.021875 & 0.000477 & 0.018204 \\
\hline 834 & 0.959444 & 0.021875 & 0.000477 & 0.018204 \\
\hline 835 & 0.959444 & 0.021875 & 0.000477 & \\
\hline 836 & 0.959444 & 0.021875 & 0.000477 & 0.018204 \\
\hline 837 & 0.972203 & 0.023744 & 0.000423 & 0.00363 \\
\hline 838 & 0.976429 & 0.019866 & 0.000981 & 0.002724 \\
\hline 839 & 0.971064 & 0.028358 & 0.000267 & \\
\hline 840 & 0.972203 & 0.023744 & 0.000423 & 0.00363 \\
\hline 841 & 0.972203 & 0.023744 & 0.000423 & 0.00363 \\
\hline 842 & 0.976429 & 0.019866 & 0.000981 & \\
\hline 843 & 0.972203 & 0.023744 & 0.000423 & 0.00363 \\
\hline 844 & 0.976429 & 0.019866 & 0.000981 & 0.002724 \\
\hline 845 & 0.972203 & 0.023744 & 0.000423 & \\
\hline 846 & 0.976429 & 0.019866 & 0.000981 & 0.002724 \\
\hline 847 & 0.972203 & 0.023744 & 0.000423 & 0.00363 \\
\hline 848 & 0.972203 & 0.023744 & 0.000423 & 0.00363 \\
\hline 849 & 0.972203 & 0.023744 & 0.00 & \\
\hline 850 & 0.959231 & 0.031043 & 0.001235 & 0.008491 \\
\hline 851 & 0.959231 & 0.031043 & 0.001235 & 0.008491 \\
\hline 852 & 0.69343 & 0.047395 & 0.000549 & $0.25 \varepsilon$ \\
\hline 853 & 0.959444 & 0.021875 & 0.000477 & 0.018204 \\
\hline 854 & 0.839519 & 0.159123 & 0.000914 & 0.000445 \\
\hline 855 & 0.947719 & 0.030957 & 0.001546 & 0.019778 \\
\hline 856 & 0.959231 & 0.031043 & 0.001235 & 0.008491 \\
\hline 857 & 0.895513 & 0.090512 & 0.002497 & 0.011478 \\
\hline 858 & 0.964644 & 0.034358 & 0.000433 & 0.000565 \\
\hline 859 & 0.835664 & 0.145262 & 0.003307 & 0.015767 \\
\hline 860 & 0.84683 & 0.149838 & 0.001054 & 0.002279 \\
\hline 861 & 0.976429 & 0.019866 & 0.000981 & 0.002724 \\
\hline 862 & 0.959231 & 0.031043 & 0.001235 & 0.008491 \\
\hline 863 & 0.961388 & 0.016545 & 0.001798 & 0.02027 \\
\hline 864 & 0.959231 & 0.031043 & 0.001235 & 0.008491 \\
\hline 865 & 0.69343 & 0.047395 & 0.000549 & 0.258626 \\
\hline 866 & 0.959444 & 0.021875 & 0.000477 & 0.018204 \\
\hline 867 & 0.839519 & 0.159123 & 0.000914 & 0.000445 \\
\hline 868 & 0.947719 & 0.030957 & 0.001546 & 0.019778 \\
\hline 869 & 0.959231 & 0.031043 & 0.001235 & 0.008491 \\
\hline 870 & 0.895513 & 0.090512 & 0.002497 & 0.011478 \\
\hline 871 & 0.964644 & 0.034358 & 0.000433 & 0.000565 \\
\hline
\end{tabular}




\begin{tabular}{|c|c|c|c|c|}
\hline 872 & 0.835664 & 0.145262 & 0.003307 & 0.015767 \\
\hline 873 & 0.84683 & 0.149838 & 0.001054 & 0.002279 \\
\hline 874 & 0.976429 & 0.019866 & 0.000981 & 0.002724 \\
\hline 875 & 0.959231 & 0.031043 & 0.001235 & 0.008491 \\
\hline 876 & 0.961388 & 0.016545 & 0.001798 & 0.02027 \\
\hline 877 & 0.959231 & 0.031043 & 0.001235 & 0.008491 \\
\hline 878 & 0.19553 & 0.788233 & 0.009134 & 0.007103 \\
\hline 879 & 0.948766 & 0.043385 & 0.000389 & 0.00746 \\
\hline 880 & 0.985217 & 0.013066 & $1.27 \mathrm{E}+04$ & 0.001717 \\
\hline 881 & 0.945724 & 0.032948 & 0.001848 & \\
\hline 882 & 0.665397 & 0.321801 & 0.011519 & 0.001283 \\
\hline 883 & 0.665397 & 0.321801 & 0.011519 & 0.001283 \\
\hline 884 & 0.926704 & 0.071614 & $6.05 \mathrm{E}+04$ & 0.001682 \\
\hline 885 & 0.23225 & 0.76054 & & \\
\hline 886 & 0.864645 & 0.135058 & 0.0002 & $9.72 E+09$ \\
\hline 887 & 0.25407 & 0.721567 & 0.004582 & 0.019781 \\
\hline 888 & 0.882297 & 0.116575 & 0.000379 & \\
\hline 889 & 0.98 & 0.018243 & $8.15 E+08$ & 0.001675 \\
\hline 890 & 0.28715 & 0.709636 & 0.002192 & 0.001022 \\
\hline 891 & 0.896835 & 0.097838 & 0.002767 & \\
\hline 892 & 0.614541 & 0.327969 & 0.004568 & 0.052921 \\
\hline 893 & 0.981009 & 0.015869 & $2.06 \mathrm{E}+04$ & 0.003123 \\
\hline 894 & 0.754292 & 0.232869 & 0.008204 & 0.004635 \\
\hline 895 & 0.956972 & 0.039415 & 0.001005 & 0.0 \\
\hline 896 & 0.2761 & 0.703945 & 0.006395 & 0.01356 \\
\hline 897 & 0.929201 & 0.064855 & $2.74 \mathrm{E}+05$ & 0.005944 \\
\hline 898 & 0.982866 & 0.016873 & $1.42 \mathrm{E}+04$ & 0.000261 \\
\hline 899 & 0.981009 & 0.015869 & $2.06 \mathrm{E}+04$ & 0.003123 \\
\hline 900 & 0.247455 & 0.684039 & 0.011202 & 0.057304 \\
\hline 901 & 0.632038 & 0.363536 & 0.003734 & 0.000 \\
\hline 902 & 0.873904 & 0.124032 & 0.000579 & 0.001 \\
\hline 903 & 0.312587 & 0.652103 & 0.004779 & 0.030531 \\
\hline 904 & 0.632038 & 0.363536 & 0.003734 & 0.000692 \\
\hline 905 & 0.588543 & 0.408539 & 0.002788 & 0.00013 \\
\hline 906 & 0.588543 & 0.408539 & 0.002788 & 0.00013 \\
\hline 907 & 0.983997 & 0.013827 & 0.000308 & 0.001869 \\
\hline 908 & 0.66951 & 0.320795 & 0.009147 & 0.000547 \\
\hline 909 & 0.915424 & 0.082172 & 0.000301 & 0.002104 \\
\hline 910 & 0.557337 & 0.289508 & 0.010398 & 0.142757 \\
\hline 911 & 0.92551 & 0.069853 & 0.00089 & 0.003746 \\
\hline 912 & 0.247948 & 0.747354 & 0.003087 & 0.001611 \\
\hline 913 & 0.922385 & 0.076119 & 0.00043 & 0.001065 \\
\hline 914 & 0.925348 & 0.064442 & 0.001794 & 0.008416 \\
\hline 915 & 0.55037 & 0.416921 & 0.010596 & 0.022113 \\
\hline 916 & 0.709299 & 0.287419 & 0.001618 & 0.001664 \\
\hline 917 & 0.593792 & 0.195078 & 0.005493 & 0.205637 \\
\hline
\end{tabular}




\begin{tabular}{|r|r|r|r|r|}
\hline 918 & 0.299956 & 0.692003 & 0.002618 & 0.005423 \\
\hline 919 & 0.35963 & 0.619204 & 0.010033 & 0.011133 \\
\hline 920 & 0.268923 & 0.692047 & 0.007893 & 0.031136 \\
\hline 921 & 0.351348 & 0.61059 & 0.01242 & 0.025642 \\
\hline 922 & 0.791802 & 0.206402 & 0.000689 & 0.001108 \\
\hline 923 & 0.476614 & 0.516654 & 0.003501 & 0.003231 \\
\hline 924 & 0.875765 & 0.123146 & 0.000458 & 0.000631 \\
\hline 925 & 0.258218 & 0.707192 & 0.009226 & 0.025364 \\
\hline 926 & 0.829383 & 0.170076 & 0.000447 & $9.38 \mathrm{E}+09$ \\
\hline 927 & 0.2761 & 0.703945 & 0.006395 & 0.01356 \\
\hline 928 & 0.899499 & 0.097222 & 0.00219 & 0.001089 \\
\hline 929 & 0.672877 & 0.326016 & 0.000971 & 0.000136 \\
\hline 930 & 0.284703 & 0.710155 & 0.002754 & 0.002388 \\
\hline 931 & 0.899499 & 0.097222 & 0.00219 & 0.001089 \\
\hline 932 & 0.934376 & 0.063491 & 0.001777 & 0.000356 \\
\hline 933 & 0.743721 & 0.251052 & 0.003923 & 0.001303 \\
\hline 934 & 0.357587 & 0.574754 & 0.011406 & 0.056254 \\
\hline 935 & 0.364662 & 0.531098 & 0.018928 & 0.085313 \\
\hline 936 & 0.364662 & 0.531098 & 0.018928 & 0.085313 \\
\hline 937 & 0.971278 & 0.028509 & $9.24 \mathrm{E}+07$ & 0.000121 \\
\hline 938 & 0.247948 & 0.747354 & 0.003087 & 0.001611 \\
\hline 939 & 0.932794 & 0.066634 & 0.000345 & 0.000226 \\
\hline 940 & 0.351348 & 0.61059 & 0.01242 & 0.025642 \\
\hline 941 & 0.615863 & 0.297817 & 0.007449 & 0.078871 \\
\hline 942 & 0.917196 & 0.081838 & 0.000474 & 0.000491 \\
\hline 943 & 0.288911 & 0.562643 & 0.00505 & 0.143397 \\
\hline 944 & 0.247948 & 0.747354 & 0.003087 & 0.001611 \\
\hline 945 & 0.920267 & 0.076392 & $9.27 \mathrm{E}+04$ & 0.003342 \\
\hline 946 & 0.66951 & 0.320795 & 0.009147 & 0.000547 \\
\hline 947 & 0.829383 & 0.170076 & 0.000447 & $9.38 \mathrm{E}+09$ \\
\hline 948 & 0.78895 & 0.207579 & 0.00087 & 0.002602 \\
\hline 949 & 0.892951 & 0.10622 & 0.000758 & $7.15 \mathrm{E}+09$ \\
\hline 950 & 0.921425 & 0.076725 & 0.00113 & 0.00072 \\
\hline 951 & 0.35963 & 0.619204 & 0.010033 & 0.011133 \\
\hline 952 & 0.279291 & 0.643146 & 0.029237 & 0.048327 \\
\hline 953 & 0.893887 & 0.10588 & 0.000114 & 0.000119 \\
\hline 954 & 0.324271 & 0.566923 & 0.007279 & 0.101527 \\
\hline 955 & 0.976321 & 0.021691 & 0.000616 & 0.001371 \\
\hline 956 & 0.951503 & 0.04714 & 0.000402 & 0.000955 \\
\hline 957 & 0.980978 & 0.014378 & $3.35 \mathrm{E}+04$ & 0.004644 \\
\hline 958 & 0.258218 & 0.707192 & 0.009226 & 0.025364 \\
\hline 959 & 0.539153 & 0.456464 & 0.004165 & 0.000218 \\
\hline 961 & 0.935198 & 0.054254 & 0.004192 & 0.006356 \\
\hline & 0.979938 & 0.019764 & $8.39 \mathrm{E}+08$ & 0.000214 \\
\hline & & & \\
\hline 9
\end{tabular}




\begin{tabular}{|r|r|r|r|r|}
\hline 964 & 0.35963 & 0.619204 & 0.010033 & 0.011133 \\
\hline 965 & 0.28715 & 0.709636 & 0.002192 & 0.001022 \\
\hline 966 & 0.665397 & 0.321801 & 0.011519 & 0.001283 \\
\hline 967 & 0.789849 & 0.206977 & 0.002691 & 0.000484 \\
\hline 968 & 0.738486 & 0.253534 & 0.006328 & 0.001652 \\
\hline 969 & 0.98944 & 0.009811 & 0.000241 & 0.000508 \\
\hline 970 & 0.861544 & 0.135578 & 0.00128 & 0.001599 \\
\hline 971 & 0.920672 & 0.077273 & 0.000698 & 0.001357 \\
\hline 972 & 0.940064 & 0.050522 & 0.007677 & 0.001738 \\
\hline 973 & 0.934126 & 0.060264 & 0.003299 & 0.002311 \\
\hline 974 & 0.953067 & 0.042538 & 0.00105 & 0.003345 \\
\hline 975 & 0.950304 & 0.04681 & 0.000643 & 0.002243 \\
\hline 976 & 0.984543 & 0.014456 & 0.000199 & 0.000802 \\
\hline 977 & 0.940216 & 0.056468 & 0.002153 & 0.001163 \\
\hline 978 & 0.977844 & 0.009937 & 0.000243 & 0.011976 \\
\hline 979 & 0.988 & 0.009145 & 0.000276 & 0.002579 \\
\hline 980 & 0.98944 & 0.009811 & 0.000241 & 0.000508 \\
\hline 981 & 0.662312 & 0.331599 & 0.005857 & 0.000232 \\
\hline 982 & 0.977844 & 0.009937 & 0.000243 & 0.011976 \\
\hline 983 & 0.951215 & 0.039174 & 0.00211 & 0.007501 \\
\hline 984 & 0.961055 & 0.035936 & $4.74 \mathrm{E}+04$ & 0.003009 \\
\hline 985 & 0.910652 & 0.085676 & 0.003319 & 0.000353 \\
\hline 986 & 0.834902 & 0.160246 & 0.002022 & 0.00283 \\
\hline 987 & 0.950465 & 0.043199 & 0.001296 & 0.00504 \\
\hline 988 & 0.948927 & 0.050071 & 0.000562 & 0.000441 \\
\hline 989 & 0.981908 & 0.00859 & $4.86 \mathrm{E}+04$ & 0.009502 \\
\hline 990 & 0.79181 & 0.205152 & 0.002291 & 0.000747 \\
\hline 991 & 0.382029 & 0.468395 & 0.009221 & 0.140355 \\
\hline 992 & 0.991581 & 0.007374 & 0.000113 & 0.000932 \\
\hline 993 & 0.964212 & 0.027381 & 0.001416 & 0.006991 \\
\hline 994 & 0.953287 & 0.038308 & 0.000211 & 0.008193 \\
\hline 995 & 0.948264 & 0.045884 & 0.00156 & 0.004293 \\
\hline 996 & 0.946095 & 0.053742 & $7.14 \mathrm{E}+09$ & $9.24 \mathrm{E}+09$ \\
\hline 997 & 0.985464 & 0.010954 & 0.000118 & 0.003464 \\
\hline 998 & 0.985509 & 0.012089 & $7.24 \mathrm{E}+08$ & 0.00233 \\
\hline 999 & 0.859303 & 0.136518 & 0.000596 & 0.003584 \\
\hline 1000 & 0.882639 & 0.114971 & 0.000375 & 0.002015 \\
\hline 1001 & 0.854421 & 0.139606 & 0.003374 & 0.002598 \\
\hline 1002 & 0.727114 & 0.142433 & 0.002239 & 0.128214 \\
\hline 1003 & 0.867695 & 0.118815 & 0.005032 & 0.008458 \\
\hline 1004 & 0.962481 & 0.035146 & 0.000535 & 0.001838 \\
\hline 1005 & 0.929607 & 0.06997 & 0.000208 & 0.000215 \\
\hline 1006 & 0.857421 & 0.138801 & 0.002672 & 0.001106 \\
\hline 1007 & 0.408394 & 0.060065 & 0.002552 & 0.528989 \\
\hline & 0.986958 & 0.011995 & $5.72 \mathrm{E}+09$ & 0.00099 \\
\hline 0.348364 & 0.622883 & 0.008677 & 0.020076 \\
\hline & & & \\
\hline
\end{tabular}




\begin{tabular}{|c|c|c|c|c|}
\hline 1010 & 0.780833 & 0.113099 & 0.006065 & 0.100003 \\
\hline 1011 & 0.957463 & 0.032639 & 0.000608 & \\
\hline 1012 & 0.607269 & 0.139912 & 0.00604 & 0.246779 \\
\hline 1013 & 0.934944 & 0.064774 & 0.000115 & 0.000167 \\
\hline 1014 & 0.984647 & 0.004363 & $2.73 \mathrm{E}+04$ & 0.01099 \\
\hline 1015 & 0.85288 & 0.13009 & 0.003851 & 0.013179 \\
\hline 1016 & 0.762916 & 0.234889 & 0.001927 & \\
\hline 1017 & 0.989869 & 0.008837 & $4.86 \mathrm{E}+09$ & 0.001245 \\
\hline 1018 & 0.965173 & 0.021363 & 0.000296 & 0.013168 \\
\hline 1019 & 0.968915 & 0.027483 & $2.62 \mathrm{E}+04$ & \\
\hline 1020 & 0.940969 & 0.017454 & 0.000424 & 152 \\
\hline 1021 & 0.928677 & 0.070553 & 0.000263 & 0.00 \\
\hline 1022 & 0.948046 & & 0.000104 & \\
\hline 1023 & 891 & 38028 & 0.00 & \\
\hline 1024 & 0.940587 & 0.056551 & 0.002457 & 0.000405 \\
\hline 1025 & 0.753761 & 1168 & 0.004778 & \\
\hline 1026 & & & & \\
\hline 1027 & 0.908805 & 0.086914 & .00304 & 0.00 \\
\hline 1028 & 0.962881 & 766 & 0.001097 & 0.00 \\
\hline 1029 & & & & \\
\hline 1030 & 0.675829 & 0.320197 & 0.003557 & 0.000 \\
\hline 1031 & 0.639786 & 0.358351 & .00181 & 5.2 \\
\hline 1032 & 0.689 & 95 & 0.0 & \\
\hline 1033 & 0.658638 & 0.335201 & & \\
\hline 1034 & 0.720804 & 0.276844 & 976 & 0.0 \\
\hline 1035 & 0.639 & 0.3583 & 181 & +09 \\
\hline 1036 & 0.929682 & & & \\
\hline 1037 & 0.9289 & 0.063169 & 152 & 0.006 \\
\hline 1038 & 0.753761 & 0.241168 & 0.004778 & 0.000293 \\
\hline 1039 & 0.930492 & 0.067922 & 0.00 & \\
\hline 1040 & 0.908 & 0.086 & 304 & \\
\hline 1041 & 0.905808 & 0.087436 & 0.00384 & 0.002917 \\
\hline 1042 & 0.749671 & 0.243554 & 0.003824 & 0.002 \\
\hline 1043 & 0.938959 & & & \\
\hline 1044 & 0.94224 & 0.052885 & 0.002814 & 0.002061 \\
\hline 1045 & 0.933189 & 0.062874 & 0.001205 & 0.002732 \\
\hline 1046 & 0.915849 & 0.081539 & 0.001986 & 0.000625 \\
\hline 1047 & 0.879325 & 0.120407 & 0.00022 & $4.73 E+08$ \\
\hline 1048 & 0.750813 & 0.242467 & 0.006031 & 0.000689 \\
\hline 1049 & 0.984873 & 0.007978 & $5.02 \mathrm{E}+04$ & 0.007149 \\
\hline 1050 & 0.451701 & 0.490038 & 0.002856 & 0.055405 \\
\hline 1051 & 0.672797 & 0.321736 & 0.004487 & 0.000979 \\
\hline 1052 & 0.987822 & 0.010289 & $1.90 \mathrm{E}+04$ & 0.001888 \\
\hline 1053 & 0.571181 & 0.423924 & 0.004785 & 0.000111 \\
\hline 1054 & 0.9289 & 0.063169 & 0.00152 & 0.006411 \\
\hline 1055 & 0.849919 & 0.138135 & 0.00437 & 0.007576 \\
\hline
\end{tabular}




\begin{tabular}{|r|r|r|r|r|}
\hline 1056 & 0.936763 & 0.057189 & 0.001969 & 0.004078 \\
\hline 1057 & 0.675829 & 0.320197 & 0.003557 & 0.000417 \\
\hline 1058 & 0.76458 & 0.228366 & 0.005541 & 0.001512 \\
\hline 1059 & 0.913893 & 0.082124 & 0.002512 & 0.001471 \\
\hline 1060 & 0.966611 & 0.032957 & 0.000295 & 0.000136 \\
\hline 1061 & 0.915849 & 0.081539 & 0.001986 & 0.000625 \\
\hline 1062 & 0.931203 & 0.067208 & 0.001052 & 0.000536 \\
\hline 1063 & 0.870102 & 0.129442 & 0.000395 & $6.08 \mathrm{E}+09$ \\
\hline 1064 & 0.908805 & 0.086914 & 0.00304 & 0.001241 \\
\hline 1065 & 0.94224 & 0.052885 & 0.002814 & 0.002061 \\
\hline 1066 & 0.912846 & 0.08669 & 0.000261 & 0.000203 \\
\hline 1067 & 0.976014 & 0.022819 & 0.000289 & 0.000878 \\
\hline 1068 & 0.775983 & 0.220784 & 0.001781 & 0.001452 \\
\hline 1069 & 0.982338 & 0.014661 & 0.000183 & 0.002818 \\
\hline 1070 & 0.836061 & 0.160642 & 0.002311 & 0.000986 \\
\hline & & & & \\
\hline
\end{tabular}




\section{B.2 Identificação das Variáveis}

\begin{tabular}{|c|c|}
\hline Variável & Descriminação \\
\hline $\mathrm{V} 1$ & Região Administrativa \\
\hline V2 & Escola \\
\hline V3 & Rede de ensino \\
\hline V4 & Grau de parentesco \\
\hline V5 & Série cursada \\
\hline V6 & Bairro da residência \\
\hline V7 & Ocupação dos pais \\
\hline V8 & Estado civil dos pais \\
\hline V9 & Renda mensal da família \\
\hline V10 & Número de automóveis da família \\
\hline V11 & Número de moradores na residência \\
\hline $\mathrm{V} 12$ & Escolaridade dos pais \\
\hline V13 & Número de habilitados na residência \\
\hline V14 & Sexo da criança \\
\hline V15 & Idade da criança \\
\hline V16 & Meio de locomoção à escola \\
\hline V17 & Acompanhante da criança na ida até à escola \\
\hline V18 & Acompanhante da criança na volta da escola \\
\hline V19 & Tempo de deslocamento até a escola \\
\hline V20 & Destino final dos pais após deixar o filho na escola \\
\hline V21 & Bairro do destino final citado no item anterior \\
\hline V22 & Dinstaância entre a escola e o destino final dos pais \\
\hline V23 & Fator mais importante na escolha da escola \\
\hline V24 & Frequência com que a criança se desloca à pe até a escola \\
\hline V25 & Frequência com que a criança se desloca de bicicleta até a escola \\
\hline V26 & Frequência com que a criança se desloca ônibus até a escola \\
\hline V27 & A pé: 4 faixas de tráfego \\
\hline V28 & A pé: 4 sem faixa de pedestre pintada \\
\hline V29 & A pé: sem iluminação pública adequada \\
\hline V30 & A pé: locais com lotes vazios \\
\hline V31 & A pé: locais onde as quadras são compridas demais \\
\hline V32 & A pé: ruas com forte inclinação \\
\hline V33 & A pé: locais onde as calçadas estão estragadas \\
\hline V34 & A pé: locais onde o fluxo de veículos é pesado \\
\hline V35 & A pé: lugares onde não existe guarda de trânsito \\
\hline V36 & A pé: lugares com alto indice de assaltos \\
\hline V37 & A pé: se a casa é distante da escola para ir a pé \\
\hline V38 & Bicicleta: ruas com mais de 4 faixas de tráfego \\
\hline V39 & Bicicleta: ruas sem faixa de pedestre pintada \\
\hline V40 & Bicicleta: locais sem iluminação pública adequada \\
\hline V41 & Bicicleta: locais com lotes vazios \\
\hline
\end{tabular}




\begin{tabular}{|c|c|}
\hline V42 & Bicicleta: ruas com rampas \\
\hline V43 & Bicicleta: locais bastante movimentado com fluxo de veículos \\
\hline V44 & Bicicleta: locais onde não exista ciclovia ou ciclofaixa \\
\hline V45 & Bicicleta: existência de estacionamento de bicicleta na escola \\
\hline V46 & Bicicleta: se há assaltos a ciclistas na região \\
\hline V47 & Bicicleta: se a casa é distante da escola para ir de bicicleta \\
\hline V48 & Ônibus: pegar ônibus lotado \\
\hline V49 & Ônibus: distância até a parada de ônibus mais perto de casa \\
\hline V50 & Ônibus: distância até a parada de ônibus mais perto da escola \\
\hline V51 & Ônibus: se espera demais na parada de ônibus \\
\hline V52 & Ônibus: se é seguro andar de ônibus até a escola \\
\hline V53 & Ônibus: se é confortável andar de ônibus até a escola?] \\
\hline V54 & Ônibus: se as paradas de ônibus são pequenas \\
\hline V55 & Ônibus: se há informações sobre as linhas e horários de chegada e partida \\
\hline V56 & Ônibus: se há muitos terminais entre sua casa e a escola \\
\hline V57 & A pé: se o filho fosse mais velho(a) \\
\hline V58 & A pé: se o clima fosse melhor \\
\hline V59 & A pé: se o bairro fosse mais seguro \\
\hline V60 & A pé: escola fosse mais perto de casa \\
\hline V61 & A pé: se houvesse ruas menos movimentada \\
\hline V62 & A pé: se tivesse guarda de trânsito \\
\hline V63 & A pé:se as calçadas fossem conservadas \\
\hline V64 & A pé: se existissem faixas de pedestre no caminho \\
\hline V65 & A pé: se as ruas tivessem boa sinalização no caminho \\
\hline V66 & Bicicleta: Se o filho mais velho(a) \\
\hline V67 & Bicicleta: se o clima fosse melhor \\
\hline V68 & Bicicleta: se o bairro fosse mais seguro \\
\hline V69 & Bicicleta: se houvesse ciclovia no caminho \\
\hline V70 & Bicicleta: se houvesse boa sinalização p/ ciclista \\
\hline V71 & Bicicleta: Se a escola fosse próximo de casa \\
\hline V72 & Bicicleta: Se houvesse ruas menos movimentadas no caminho \\
\hline V73 & Ônibus: se o filho mais velho(a) \\
\hline V74 & Ônibus: as paradas fossem maiores e seguras \\
\hline V75 & Ônibus: as paradas fossem mais perto de casa \\
\hline V76 & Ônibus: as paradas fossem mais perto da escola \\
\hline V77 & Ônibus: se houvessem mais linha de ônibus \\
\hline V78 & Ônibus: se andar de ônibus fosse mais rápido \\
\hline V79 & Ônibus:se os ônibus fossem pontuais \\
\hline V80 & Ônibus: se os ônibus não fossem lotados \\
\hline V81 & Ônibus: se os ônibus fossem novose limpos \\
\hline V82 & Ônibus: se andar de ônibus fosse mais confortável \\
\hline V83 & Ônibus: se andar de ônibus fosse mais seguro \\
\hline V84 & Ônibus :se os ônibus passassem nos horários das planilhas \\
\hline V85 & Andar a pé :se os pais acham bom para a saúde dos seus filhos \\
\hline V86 & Andar de bicicleta: se os pais acham bom para a saúde dos seus filhos \\
\hline V87 & Pegar ônibus até a escola contribuia para diminuir o tráfego de carros na cidade \\
\hline
\end{tabular}




\begin{tabular}{|c|c|}
\hline V88 & $\begin{array}{l}\text { Se os pais não se sentem à vontade de deixar seu filho ir a pé por receio de } \\
\text { estranhos }\end{array}$ \\
\hline V89 & Se os pais não se sentem à vontade de deixar seu filho ir de bicicleta pelo trânsito \\
\hline V90 & $\begin{array}{l}\text { Se os pais não se sentem à vontade de deixar seu filho pelo tempo de } \\
\text { deslocamento }\end{array}$ \\
\hline V91 & Longa distância ate à escola para que meu filho se desloque a pé até ela \\
\hline V92 & Longa distância até a escola para que meu filho se desloque de bicicleta até ela \\
\hline V93 & Grande fluxo de carros no trajeto de seu filho por isso não se sente seguro \\
\hline V94 & Bairro da residência não é seguro o suficiente para meu filho ir a pé até a escola \\
\hline V95 & Bairro da residência não é seguro para meu filho ir de bicicleta até a escola \\
\hline V96 & Os ônibus não são seguros para que eu deixe meu filho pegá-lo para ir até a escola \\
\hline V97 & Levar o filho de carro até a escola é mais conveniente para os pais \\
\hline V98 & O clima quente dificulta o filho ir a pé até a escola \\
\hline V99 & O clima quente dificulta o filho ir de bicicleta até a escola \\
\hline V100 & Os pais não se preocupam em incentivar o filho a se deslocar a pé até a escola \\
\hline V101 & Os pais não se preocupam em incentivar o filho a se deslocar de bicicleta a escola \\
\hline V102 & $\begin{array}{l}\text { Os pais não se preocupam em incentivar o filho a se deslocar de ônubus até a } \\
\text { escola }\end{array}$ \\
\hline V103 & O filho não gosta de caminhar ou andar de bicicleta até a escola \\
\hline V104 & O filho não gosta de ir de ônibus até a escola \\
\hline V105 & Se na saída casa para ir a escola está muito cedo e escuro para o filho ir a escola \\
\hline V106 & Se na saída de casa para ir a escola está muito cedo e escuro para ir de bicicleta \\
\hline V107 & $\begin{array}{l}\text { Se na saída de casa para ir a escola ainda está muito cedo/escuro para ir de } \\
\text { ônibus }\end{array}$ \\
\hline V108 & Área do Setor \\
\hline V109 & Comprimento total das vias \\
\hline V110 & Densidade de vias \\
\hline V111 & Numero total de quadras \\
\hline V112 & Densidade de quadras \\
\hline V113 & Comprimento médio das quadras \\
\hline V114 & Número de interseções em cruz \\
\hline V115 & Número de interseções em T \\
\hline V116 & Número total de interseções \\
\hline V117 & Densidade de Interseções \\
\hline V118 & Conectividade \\
\hline V119 & Largura média das calçadas \\
\hline V120 & Linhas do transporte público que atendem \\
\hline V121 & Linhas do transporte público que margeiam \\
\hline V122 & Ciclovia \\
\hline V123 & Ciclorota \\
\hline V124 & Ciclofaixa \\
\hline
\end{tabular}

